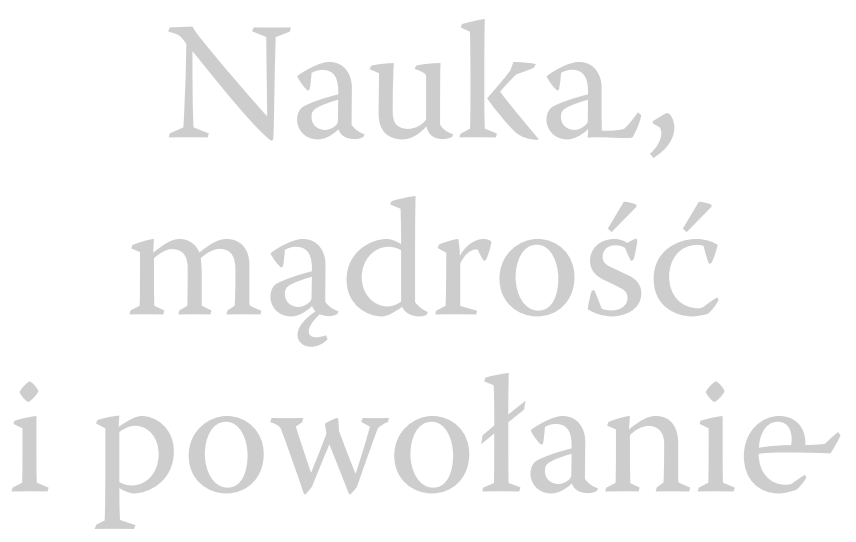


Ministerium Expositionis

3 
ks. Janusz Królikowski

\section{Nauka, \\ mądrość \\ i powołanie \\ O naturze i misji teologii}

Uniwersytet Papieski Jana Pawła II w Krakowie Wydawnictwo Naukowe

Kraków 2016 
Recenzja wydawnicza

ks. prof. dr hab. Bogdan Ferdek

Korekta

Katarzyna Romanek

Redakcja techniczna

Jadwiga Malik

Projekt serii i okładki

Marta Jaszczuk

Na okładce

Justus Sadeler, Święty Tomasz z Akwinu, ok. 16oo; ze zbiorów autora.

Publikacja finansowana $\mathrm{z}$ dotacji na utrzymanie potencjału badawczego Uniwersytetu Papieskiego Jana Pawła II w Krakowie przyznanej przez Ministra Nauki i Szkolnictwa Wyższego w roku 2015.

Copyright () 2016 by Uniwersytet Papieski Jana Pawła II w Krakowie

ISBN 978-83-7438-513-8 (wersja drukowana)

ISBN 978-83-7438-514-5 (wersja online)

DOI: http://dx.doi.org/10.15633/9788374385145

Uniwersytet Papieski Jana Pawła II w Krakowie

Wydawnictwo Naukowe

30-348 Kraków, ul. Bobrzyńskiego 10

tel./faks (12) 4.226040

e-mail:wydawnictwo@upjp2.edu.pl

www.ksiegarnia.upjp2.edu.pl 


\section{米 \\ Wprowadzenie}

Teologia jest specyficzną dziedziną nauki, ponieważ odpowiada na specyficzne pytania zadawane przez człowieka. Wśród tych pytań znajduje się przede wszystkim pytanie o śmierć. W tym znaczeniu można powiedzieć, że punktem wyjścia teologii - „nauki o Bogu” jest kwestia dogłębnie antropologiczna, gdyż szuka ona odpowiedzi dotyczących człowieka. Pytanie o śmierć jest w najwyższym stopniu pytaniem o sens ludzkiej egzystencji, która w obliczu śmierci, jej nieuchronności i jej powszechności osiąga swój punkt krytyczny. W udzielaniu odpowiedzi na to pytanie chodzi właściwie o to, by sprostać życiu w perspektywie śmierci i w tej perspektywie szukać szczęścia, do którego człowiek czuje się w najwyższym stopniu powołany oraz przeznaczony.

Pytanie o śmierć stanowi więc zasadniczy horyzont ludzkiego myślenia, które podejmuje teologia. Tak określony punkt wyjścia teologii rodzi również pytanie o to, jaki typ rozumienia może być adekwatny do jego podjęcia i udzielenia spójnej odpowiedzi. Już intuicja podpowiada, że nie wystarczy w tym przypadku oprzeć się na metodzie empirycznej, ponieważ nie chwyta ona przedmiotu, o który chodzi w pytaniu o śmierć - o związane z nią „dlaczego?". Do tego pytania nie wystarczy podejście tylko racjonalistyczne, które co najwyżej pozwoliłoby na opisanie przedmiotu, do którego ono się odnosi. Potrzebne jest podejście, które pozwo- 
liłoby przekroczyć sam przedmiot pytania, patrząc na niego z pewnej metaperspektywy, czyli właściwie z punktu widzenia Boga. I tu powracamy do teologii, która jako jedyna z nauk pokazuje ostateczny horyzont ludzkiej egzystencji, a tym samym daje racje uzasadniające, że nie należy abdykować wobec śmierci, a tym samym także wobec życia. Tak określona perspektywa poszukiwań teologicznych stawia pilny postulat refleksji teologicznej, która otwiera się na mądrość, która pozwala na spojrzenie na życie z najwyższej perspektywy, jedynej zdolnej do uporządkowania spraw ludzkich. Papież Benedykt XVI we wskazaniach dotyczących badań naukowych we wspólczesnym świecie, wobec rozmaitych redukcjonizmów wprowadzonych i utrzymywanych przez mentalność pozytywistyczną, mówi o potrzebie „poszerzenia granic racjonalności”. To poszerzenie oznacza przede wszystkim otwarcie się na mądrość, a teologia stanowi jeden z obszarów tej poszerzonej racjonalności.

Teologia chrześcijańska ma wielorakie doświadczenia, które potwierdzają, że takie podejście do człowieka i jego pytań zawsze było w niej obecne, przynosząc bogate owoce służby na rzecz człowieka. Jest to nurt teologii ujmowanej w perspektywie mądrości, która stara się o dokonanie twórczej i przymawiającej syntezy między myślą i sercem. W tym nurcie sytuuje się na przykład teologia św. Augustyna, św. Bonawentury, Romano Guardiniego, papieża Jana Pawła II i papieża Benedykta XVI. Jest to nurt żywy w teologii naszych czasów, starającej się odpowiadać na najbardziej podstawowe ludzkie pytania sub ratione Dei. 


\section{ROZDZIAŁ I}

\section{米 \\ Powołanie teologa}

Bóg objawił się ludziom. To objawienie wymaga, aby ludzie coraz bardziej postępowali w jego zrozumieniu, gdyż tylko w ten sposób będą mogli żyć zgodnie z nim i osiągnąć to, co ono im zapowiada. Objawienie zwrócone do człowieka jako istoty rozumnej i wolnej wskazuje, że Bogu chodzi o to, by człowiek żył i dążył do Niego nie w sposób mechaniczny, ale świadomy i wolny, gdyż tylko wtedy prawda objawiona może stać się życiem w pójściu za Chrystusem. Prawda Boża nie jest bowiem teorią, ale bardzo konkretnym życiem miłości - miłości trynitarnej w wewnętrznym życiu Boga w wieczności, która staje się darem dla człowieka w stworzeniu - w jego czasie i historii - oraz w odkupieniu.

Z tych kilku podstawowych stwierdzeń wyłania się wskazanie dotyczące funkcji tego, kto w Kościele jest w szczególny sposób powołany do zrozumienia - coraz głębszego i możliwego w coraz większym stopniu - objawienia Bożego. Takie zrozumienie jest możliwe tylko w oparciu o dyspozycyjność serca na przyjęcie prawdy Bożej, która jest większa od naszego serca i naszego rozumu. Tą dyspozycyjnością jest wiara. Duch Święty może dać człowiekowi tę dyspozycyjność i Jezus wymaga jej bezpośrednio, gdy napomina swoich uczniów: „I wy tak niepojętni jesteście?” (Mk 7, 18). A w innym miejscu czytamy: „Wyrzucał im brak wiary i upór, że nie uwierzyli tym, którzy widzieli Go zmartwychwstałego" (Mk 16, 14). 
Święty Bonawentura tak mówi o znaczeniu wiary w zgłębianiu objawienia: „Niemożliwe jest, aby ktoś mógł zrozumieć Pismo, jeśliby wcześniej nie miał w sobie wiary Chrystusa jako światła, bramy oraz fundamentu całego Pisma. Jak długo bowiem pielgrzymujemy $\mathrm{z}$ dala od Pana, tak długo jedynie wiara jest fundamentem podtrzymującym, światłem kierującym, bramą wprowadzającą do wszystkich nadprzyrodzonych oświeceń"

Celem tego zrozumienia jest życie traktowane jako pójście za Chrystusem. Odnosi się to oczywiście najpierw do samego teologa, który - podobnie jak wszyscy - może osiągnąć głębsze zrozumienie prawdy za pośrednictwem rzeczywistego i czynnego pójścia za Chrystusem. Jezus mówi przecież: „Jeżeli będziecie trwać w nauce mojej, będziecie prawdziwie moimi uczniami" (J 8, 11). Wszystkie wysiłki teologa muszą być nastawione na promowanie, w jego braciach w Chrystusie, życia, które byłoby w coraz większym stopniu i coraz bardziej konsekwentnym pójściem za Chrystusem. Z punktu widzenia chrześcijańskiego celem teologii nie jest ona sama w nie może ona zadowalać się sobą. Jej właściwym celem jest ukazywanie człowiekowi perspektywy zbawienia i dlatego też jest nazywana „wiedzą zbawienia - scientia salutis.

Powyższe uwagi pozwalają nam zrozumieć dwie rzeczy. Pierwsza znajduje wyraz w wypowiedziach Jezusa o tym, że dyspozycyjność serca tych, których nazywa „prostaczkami” (Mt 11, 25; Łk 10, 21) i „ubogimi w duchu” (Mt 5, 3), umożliwia zrozumienie Ojca w o wiele większym stopniu, niż ma to miejsce w przypadku „mądrych i roztropnych”, to znaczy tych, którzy uważają, iż wiedzą już wszystko, i to o wiele lepiej, i dlatego nie otwierają się na prawdę Bożą, która jest większa od nich. Tym, co pozwala na głębsze poznanie objawienia, nie jest liczba poznanych rzeczy, ale spojrzenie, które sięga prosto do centrum, nie zatrzymując się na rzeczach drugorzędnych; spojrzenie, które - właśnie dzięki swojej „prostocie” - ujmuje całość i to, co istotne, lepiej niż to czyni uczony, który drobiazgowo analizuje jakiś tekst czy jakieś zagadnienie. W tym znaczeniu

1 Bonawentura, Breviloquium, [w:] Liturgia godzin, t. 3, s. 142. 
wypowiedzi Jezusa przeciw uczonym w Piśmie i na rzecz ludzi prostych nie utraciły niczego ze swojej wartości także w Kościele. Nie straciło wartości napomnienie Jezusa: „Biada wam, uczeni w Piśmie i faryzeusze obłudnicy, bo zamykacie królestwo niebieskie przed ludźmi. Wy sami nie wchodzicie i nie pozwalacie wejść tym, którzy do niego idą" (Mt 23, 13).

Z tego, co zostało powiedziane na początku, wynika także i to, że Bóg pozwala tym, którzy w wyjątkowym stopniu idą za Jego Synem, to znaczy świętym, przeniknąć w sposób szczególnie jasny sens Jego objawienia. Święci doświadczają nie tylko teoretycznego poznania Boga, ale poznania, które nabywa się za pośrednictwem modlitwy i przeżywanej wiary, a więc poznania, które możemy nazwać doświadczalnym.

Francuski teolog Louis Bouyer w swojej książce wywiadzie na temat „zawodu teologa” mówi znacząco: „Te ologia w starożytnym języku greckim oznacza przede wszystkim cześć oddawaną bóstwu za pośrednictwem poświęconego mu hymnu. W ten sposób, na przykład, hymny homeryckie wysławiają wielkie bóstwa Grecji. Ojcowie Kościoła przejmują pojęcie w tym właśnie znaczeniu. Jeśli Jan zostaje nazwany «teologiem» i jeśli później Grzegorz z Nazjanzu, a w epoce bizantyńskiej Symeon, zostają określeni mianem «nowych teologów», to nie oznacza to czego innego, ale to, że podnosili równocześnie wierzących do wyższego i bogatszego wychwalania chwały Bożej. Teologia, która nie wzbudzałaby takiego ruchu, nie byłaby autentyczną teologią"2. Oznacza to, że każdy święty jest jakąś teologią dla Ko ści ioła. Dlatego konieczne jest do tego szczególne powołanie - jest konieczne to, co nazywa się charyzmatem nauczania ${ }^{3}$. Święty Paweł dużo mówi na ten temat, nie mając na myśli tylko teologów naszych czasów. Jest znaczący fakt, że Kościół ogłosił „doktorami Kościoła” różnych świętych,

2 L. Bouyer, Le métier de théologien, Paris 1979, s. 209.

3 Wiele ważnych uwag na ten temat zawiera instrukcja o powołaniu teologa w Kościele Donum veritatis Kongregacji Nauki Wiary. Por. W trosce o petnię wiary. Dokumenty Kongregacji Nauki Wiary 1966-1994, red. J. Królikowski, Z. Zimowski, Tarnów 2010, s. 425-445. 
wśród nich także kobiety, którzy nie byli zawodowymi teologami. Święte Hildegarda z Bingen, Katarzyna ze Sieny, Teresa z Ávili i Teresa z Lisieux osiągnęły wewnętrzną wizję intelektualną prawdy chrześcijańskiej, wizję tak jasną i tak dogłębną, że były w stanie zbliżać wierzących do świetlanego centrum wieczności ${ }^{4}$.

Wyłania się w ten sposób drugi punkt. Jak Kościół jest tym, który otrzymuje i przekazuje objawienie Boże, i jak z tego powodu każdy poszczególny wierzący może być pewny, że uczestniczy w sensie pełnym i prawdziwym w tym objawieniu, tylko pozostając $w$ ramach wiary eklezjalnej, tak również teologia nie może być niczym innym, jak pośredniczeniem wiary Kościoła, nastawionym na jej coraz dalej idące pogłębienie. Dobrze wyraża to zagadnienie cytowany wyżej Louis Bouyer: „Teologia katolicka nie może być niczym innym, jak wyjaśnieniem wiary eklezjalnej; nie ma pełnej i autentycznej wiary chrześcijańskiej poza wiarą Kościoła. Kościół jest partnerem objawienia. Jeśli teolog stara się czynić coś innego, niż to, co byłoby rozwojem i wiarą Kościoła, jeśli stara się na przykład zbudować swój własny system, to stawia się tym samym poza teologia godną tego imienia. Jest naturalne, że każdy poszczególny teolog zależy od swego czasu oraz od swoich współrzędnych duchowych i kulturowych. Jednak, jako jednostka lub jako grupa, będzie mógł być nazywany teologiem tylko wtedy, jeśli pracuje w ramach świadomości eklezjalnej. Najgorszą oceną, jaką można dać teologowi, nawet genialnemu, byłoby więc stwierdzenie, że jego dzieła pozwalają nam poznać jego myśl. Dzieło prawdziwego teologa nie ma wyrażać jego osobistej myśli, ale «myśl Chrystusa» (1 Kor 2, 16), jaką może nam dać tylko sensus Ecclesiae i jaka jest strzeżona żywa tylko przez Kościół”’

Ta „myśl Chrystusa” jest nam dawana z jednej strony w sposób ogólny, przez świadomość wiary wszystkich wierzących, a z drugiej w sposób specyficzny, za pośrednictwem urzędu pasterskiego, przeznaczonego do tego właśnie celu, który jest równocześnie urzędem nauczycielskim. W żadnym przypadku nie jest dopuszczal-

4 Por. H. U. von Balthasar, Teologia a świętość, [w:] Podstawy wiary - teologia, red. L. Balter i in., Poznań 1991, s. 424-432 (Kolekcja Communio, 6).

5 L. Bouyer, Le métier de théologien, s. 208-209. 
ne przeciwstawienie między „urzędem pasterskim”, wypełnianym przez biskupów, na czele z papieżem, który miałby tylko charakter pasterski, „urzędowi nauczycielskiemu”, który przysługiwałby tylko lub na pierwszym miejscu teologom. Ten sposób widzenia, który rozpowszechnił się ostatnio, pomniejsza jedność, jaką gwarantuje Ewangelia, zachodzącą między działalnością nauczycielską i działalnością pasterską (por. Mt 28, 18n). Święty Paweł jest wyjątkowym przykładem jedności w spełnianiu tych dwóch działań ${ }^{\text {. }}$

W Kościele mogą być „nauczyciele” ze swoją funkcją specyficzną, co ewidentnie potwierdza Nowy Testament, ale nie są oni niezależni od organizmów mających władzę sądzenia w Kościele, które mają czuwać nad czystością wiary. Pozycja nauczycieli, tak jak innych urzędów kościelnych, ma istotnie charakter służebny. Mają oni przede wszystkim służyć pomocą w pogłębionym zrozumieniu objawienia i w jego głoszeniu adekwatnym do chwili historycznej - najpierw tym, których służba polega na prowadzeniu Kościoła, a potem także wszystkim wierzącym, którzy również szukają takiego pogłębionego zrozumienia ${ }^{7}$.

Aby ta pomoc mogła być okazywana skutecznie, teologowie muszą coraz pełniej utożsamiać się z powszechną wiarą Kościoła; nie mogą czuć się zwolnieni z całościowego zrozumienia wiary, jaka jest im przekazana. Właśnie zrozumienie wiary stanowi przedmi ot ich nauki. Święty Tomasz z Akwinu wyraża to przekonanie, stwierdzając, że przedmiotem teologii są „artykuły wiary” Kościoła. Kiedy zaś mówi o „artykułach wiary”, to ma na myśli zarówno treść wiary, jak i akt wiary. Każda nauka, jeśli chodzi o jej metodę, jest określona przez jej przedmiot. Treść określa metodę, a więc byłoby absurdem, gdyby uczony chciał stosować taką metodę, która zaciemnia lub niszczy przedmiot jego poszukiwania.

Przed teologiem stoi zatem zadanie wyjaśniania istotnych treści wiary katolickiej. Oznacza to, że ma pokazać jej głęboką jedność, współprzenikanie się jej treści i ich wzajemne zależności. Zadaniem teologa jest pokazać wewnętrzną i organiczną jedność żywego ciała

6 Por. Magisterium - teolog. Historia dialogu, red. Z. Kijas, Kraków 1996.

7 Por. La teologia, annuncio e dialogo, a cura di G. Tanzella-Nitti, Roma 1996. 
prawdy - ciała, które składa się z wielu członków. W ten sposób może on prowadzić do tego, czego Jezus wymaga od aktu wiary, a mianowicie prostej wizji całości. Ojcowie Kościoła, bliscy świadkowie Ewangelii, byli w szczególny sposób zgodni co do tej jednoczącej wizji. Taka wizja jest szczególnie potrzebna także dzisiaj, gdy teologia jest zarażona fragmentarycznością, w której analizuje się tysiące szczegółowych kwestii przy pomocy tysięcy szczegółowych metodologii. W ten sposób gubią się istota i piękno wiary chrześcijańskiej, a w jej miejsce wchodzi coraz większa niepewność w stosunku do niej. W dużym stopniu wynika to z faktu, że począwszy od oświecenia, w stosunku do treści wiary zostały zastosowane takie metody, które od wewnątrz zagrażają jej zniszczeniem. Taką metodą jest na przykład tak zwana metoda "historyczno-krytyczna”, która analizuje Pismo Święte w taki sam sposób, w jaki analizuje się każdy inny dokument literacki (abstrahując od jego natchnienia i Boskiego pochodzenia), aby ustalić w sposób „naukowy”, że jego treść ma charakter czysto ludzki. Nie dziwi więc, że pozostawiając na boku wiarę, dochodzi się do wyników, które nie zgadzają się już $\mathrm{z}$ wiarą strzeżoną i przekazywaną przez Kościół.

Teologia nie musi oczywiście rezygnować z tych metod, jakie wypracowały nauki nowożytne. Objawienie Starego i Nowego Testamentu ma swój aspekt ludzki (Izrael znajduje się pod wpływem otaczających go kultur, a św. Paweł niesie Ewangelię poganom), a więc wszystkie związki, jakie mają wymiar ludzki, są ważne dla dokładnego poznania prawdy biblijnej. Nauki antropologiczne mogą pomóc w skuteczniejszym przekazywaniu objawienia biblijnego i wiary dzisiejszemu człowiekowi. To wszystko jest prawdą, przy czym należy zauważyć, że istnieje tu ograniczenie, które powinien uwzględnić teolog w swoim zmyśle krytycznym. Jest niemożliwe, aby wszystkie te metody, opracowane ze względu na treść świecką i mogące odpowiednio funkcjonować na tym polu, mogły okazać się wystarczające do tego, co jest właściwą i prawdziwą treścią wiary. Jest możliwe, dozwolone, a nawet konieczne zastosowanie ich do tej treści, ale nie są one kompetentne do „zdominowania” elementu Boskiego, jaki tam się objawia. Żadna nauka ludzka i żadna metoda świecka nie może „zapanować” nad Bogiem. Teolog może je 
stosować, jeśli są dla niego użyteczne dla osiągnięcia jego celu, ale powinien je porzucić, skoro tylko zaczną go od tego celu oddalać.

Niezależnie od stosowanej metody teolog musi zawsze uważać, aby swoim badaniem nie pozbawiać misteriów wiary ich ciężaru gatun kow e go; musi zwracać uwagę, aby nie pomniejszać ich, aż staną się - z głębokich misteriów, jakimi są, niczym innym, niż banałem; musi być uważny, by nie zmieniać ich z samoobjawień Boga, jakimi są, umiejscowionych ponad wszelkimi oczekiwaniami, w coś, co w gruncie rzeczy człowiek już zawsze wiedział i czego oczekiwał. Oznaczałoby to po prostu koniec wiary i Kościoła chrześcijańskiego.

Jaka jest więc pozycja teologa w Kościele? Jest on tym, który pomaga zarówno pełniącym w Kościele urząd pasterski, jak i prostym wiernym w lepszym zrozumieniu i głębszym przeżywaniu wiary chrześcijańskiej, opartej na objawieniu Bożym. Nie oznacza to, że każdy wynik analizy teologicznej może i musi znaleźć b ezpośre dnie zastosowanie duszpasterskie lub że może być wyrażony w formie jakiegoś wskazania duszpasterskiego. Są wyniki pośrednie, które muszą zostać włączone w całościową wizję teologiczną, zanim będą mogły być zastosowane w sposób konkretny w życiu, to znaczy w modlitwie i działaniu, Kościoła, a w końcu także całego świata.

Teolog jest w stanie wypełnić tę funkcję tylko wtedy, gdy jego wiedza ma jasne centrum, jeśli nie wpada $\mathrm{w}$ dwie pozycje ekstremalne, to znaczy jeśli z jednej strony nie staje się wiedzą ezoteryczną, ukrytą, zamkniętą w sobie, niezrozumiałą dla niewtajemniczonych, a z drugiej jeśli nie jest po prostu materiałem dla katechezy czy przepowiadania. Odpowiada porządkowi rzeczy fakt, że istnieją specjalistyczne przeglądy naukowe, które nie są na poziomie dostępnym dla wszystkich, gdyż pewne problemy muszą być najpierw dyskutowane w kręgu specjalistów, nie stając się łatwym materiałem dla pulpitów kaznodziejskich i szpalt powierzchownych dzienników. Także to służy pogłębieniu i wyrażeniu eklezjalności teologii. W tych ramach mogą nawiązywać się nowe więzy eklezjalne teologa, które służą jego wolności, jaka przysługuje mu na podstawie objawienia chrześcijańskiego, w które wierzy. 
Wszystkie opisane tu elementy teologii i powołania teologa, jakie wynikają z dziedziny wiedzy, którą się zajmuje, prowadzą autentycznego teologa do uwidaczniania w swoim życiu i w swojej pracy ośrodka myśli Kościoła. Ten ośrodek wyznacza Credo Kościoła, w którym w oparciu o odkupienie świata dokonane przez Syna Bożego - „Boga prawdziwego z Boga prawdziwego” - perspektywa poszerza się o Boga Jedynego i Troistego, o stworzenie, o Kościól, o ostateczną nadzieję życia. To centrum ma dość światła, by oświecić także początek i koniec świata, nadając sens rzeczywistości i wydarzeniom historii. To centrum zawiera w sobie zdolność odczuwania, że zawsze jesteśmy wobec przygody, którą otwiera przed człowiekiem sam Bóg - tej przygody, dla której warto do końca poświęcić życie. 
ROZDZIAŁ II

米

\section{Integralność i integracja teologii. Wyzwania stojące przed teologami na początku nowego wieku}

Teologia, która nie będzie aktualna, będzie teologią fałszywą

Henri Bouillard ${ }^{1}$

Święty Tomasz z Akwinu, którego ciągle jeszcze posądza się o brak wrażliwości historycznej w uprawianiu teologii, jest autorem następującego stwierdzenia: „Explicatio accidit fidei nec mutat essentiam fidei, sic et variatio temporis determinat, non variat fidei" ${ }^{\prime 2}$ Variatio temporis nie wpływa na to, czym jest wiara w sobie, ale ją determinuje, czyli określa sposób jej wyrażania się w konkretnym czasie i miejscu. Odzwierciedlanie się tego zjawiska najlepiej widać w teologii, czyli systematycznej refleksji nad wiarą, jej rozumieniem i jej wyrażaniem się. Każda autentyczna teologia jest taką próbą rozumienia wiary (auditus fidei), która w sposób niemal bezpośredni uwzględnia jej kontekst historyczny (auditus temporis).

1 H. Bouillard, Conversion et grâce chez S. Thomas d'Aquin. Etude historique, Paris 1944, s. 219.

2 Tomasz z Akwinu, In III Sententiarum d. 24 a. 1 q. 3 c. 
Dlatego też teologia często stanowi najlepsze źródło do poznania ducha poszczególnych epok historycznych i kulturowych w ich znaczeniu dla człowieka. Słuszna jest więc teza Karla Heinza Neufelda, niemieckiego teologa i dyrektora Karl-Rahner-Archiv w Innsbrucku, według którego „refleksja o wierze jest punktem przecięcia dróg ducha ludzkiego"3.

Dzisiaj, gdy staliśmy się szczególnie wrażliwi na fakt „historyczności" wszystkiego, co przeżywamy i co nas otacza, musimy podejmować coraz dalej idące refleksje, które sytuowałyby się na linii spotkania między variatio temporis i drogami ducha ludzkiego z jednej strony - i tym, co stanowi przedmiot naszej wiary w jej wielorakich aspektach i formach wyrazu - z drugiej. Wiara nie jest nam dana do dyspozycji w sformułowaniu, by tak rzec, już skonfigurowanym, w takim znaczeniu, że nie mamy do zrobienia nic innego, jak tylko ją biernie zaakceptować. Każde czasy muszą ją reformułować niejako dla siebie, co oczywiście nie oznacza jej dowolnego przedstawienia lub sprowadzenia do ducha czasów.

Ponieważ variatio temporis jest dzisiaj faktem powszechnie zauważanym, a wiara ma nadal stanowić ośrodek życia każdego człowieka, pojawia się także pytanie o zadania stające przed teologiem, który chce czynnie uczestniczyć w dokonujących się przemianach duchowo-kulturowych oraz który ma nadal towarzyszyć wierze poprzez kultywowaną przez siebie teologię rozumianą zasadniczo jako scientia salutis, czyli pomagać człowiekowi w wypełnieniu jego jedynego powołania - tego boskiego ${ }^{4}$. Chodzi tutaj o zadania teologa, a nie teologii, ponieważ wychodzimy z założenia, że teolog jest czymś więcej niż teologia. Inspirujemy się w tym stwierdzeniem Franza Rosenzweiga, który mówił, że filozof jest zawsze czymś więcej niż filozofia.

Aby określić możliwe wyzwania, które stają przed dzisiejszymi teologami, a o które chodzi w niniejszej refleksji, najpierw bardzo ogólnie określimy jej dzisiejszy stan, mając szczególnie na uwadze

3 K. H. Neufeld, Teologia e università, [w:] Teologia e formazione teologica. Problemi e prospettive, a cura di S. Muratore, Cinisello Balsamo 1996, s. 168.

4 Por. II Sobór Watykański, konst. Gaudium et spes, 22. 
trudności, których doświadcza. Istnieją racje, które uzasadniają taki właśnie sposób postępowania.

\section{SYTUACJA DUCHOWA DZISIEJSZEJ TEOLOGII}

Patrząc globalnie na teologię XX wieku w jej odniesieniu do następującej w nim „zmiany czasu”, stajemy w obliczu konieczności stwierdzenia, że jej sytuacja i kondycja są poniekąd „dialektyczne" ${ }^{\prime \prime}$ W stwierdzeniu tym chodzi o odnotowanie jakby dwóch biegunów, które decydują o jej przejawianiu się i o propozycjach, które ona formułuje. $\mathrm{Z}$ jednej więc strony w wielu dziedzinach i w wielu kwestiach teologicznych dokonało się zdecydowane pogłębienie nauczania wiary w odniesieniu do rozwijających się intensywnie i wszechstronnie dróg ducha ludzkiego. Jednak z drugiej strony, co trzeba otwarcie przyznać, rzadko kiedy w historii teologii pojawiał się taki nawał powiedzianych i napisanych absurdalnych propozycji oraz zaproponowanych tez, które w imię nowych czasów wprost zakwestionowały sens wszelkiej teologii, na przykład w ramach tak zwanej „teologii śmierci Boga”. Na szczęście nie pojawiła się żadna nowa herezja na miarę wczesnochrześcijańskiego arianizmu czy dziewiętnastowiecznego modernizmu, a tym samym nie wstrząsnęła wiarą w tym kruchym i wątłym dla rozwoju ducha ludzkiego okresie - tym „czasie ubóstwa”, jak określił go Martin Heidegger.

Ogólny więc klimat, jaki dzisiaj odzwierciedla się w postawie teologów, widzących wielkość swoich możliwości, a zarazem czyhających na nich niebezpieczeństw, jest klimatem wyczekiwania na jakiś impuls, program czy wytyczne, które pozwoliłyby wprowadzić wyższe ordo do teologii jako nauki. Tymczasem jednak sformułowanie programu czy wytycznych, które domaga się posiadania obfitego

5 Por. M. Schoof, Przełom w teologii katolickiej. Poczatki, drogi, perspektywy, tłum. H. Bortnowska, Kraków 1972; R. Winling, Teologia współczesna. 1945 1980, tłum. K. Kisielewska-Sławińska, Kraków 1990; Fermenti nella teologia alle soglie del terzo millennio. Atti del III Simposio Internazionale della Facoltà di Teologia (Roma, 12-14 marzo 1997), a cura di H. Fitte, Città del Vaticano 1998. 
daru ducha profetycznego, nie jest czymś łatwym do wykonania, gdyż po wielości i zasięgu podjętych już poszukiwań oraz po często entuzjastycznie sformułowanych programach, które - jak się szybko okazywało - nie wytrzymały próby czasu, wielu teologów zwątpiło w możliwość wypracowania jednoznacznych i wszechobejmujących propozycji pod adresem teologii na przyszłość. Bodaj ostatnim teologiem, który jeszcze próbował dokonać czegoś takiego, był Karl Rahner.

Wydaje się jednak, że mimo wszystkich napotykanych ograniczeń globalne spojrzenie na teologię w XX wieku może się okazać bardzo pomocne, by właśnie na jego tle spróbować określić - przynajmniej ogólnie - wyzwania, które stają przed nią i czekają na podjęcie. Jak potwierdza doświadczenie, wyzwania do podjęcia ujawniają się ze szczególną wyrazistością wtedy, gdy zwracamy uwagę na trudności, z jakimi aktualnie mamy do czynienia, gdyż w nich najwyraźniej zagęszczają się newralgiczne momenty sytuacji ludzkich oraz sytuacji, których doświadczają różne dziedziny nauki. Z historii wiemy, że wytyczne wypracowywane właśnie w oparciu o taką metodę zawsze były owocne dla dalszego rozwoju różnych dziedzin wiedzy. Wydaje się, że sposób dochodzenia do takich wytycznych został sformułowany dość przekonująco i wyraziście już przez Arystotelesa, nie tracąc niczego ze swojej aktualności. W Metafizyce Stagiryta formułuje takie pryncypium w odniesieniu do postępowania badawczego: „W interesie poszukiwanej wiedzy należy zacząć od zbadania problemów, które trzeba najpierw przedyskutować. [...] Dla tych, którzy chcą rozwiązać trudności, będzie pożyteczne dobre ich przedyskutowanie; bo swobodna dyskusja zapewnia rozwiązanie istniejących przedtem trudności, a rozwiązać węzła nie można, jeśli się nic o nim nie wie; otóż trudności, jakie napotyka nasza myśl, wskazują na istnienie takiego «węzła» w przedmiocie"6.

Jakie są więc trudności, których doświadcza teologia na początku nowego wieku? Jeśli chodzi o stan duchowy dzisiejszej teologii, to trzeba najpierw powiedzieć, że co do swoich zasadniczych

6 Arystoteles, Metafizyka (III 995a), [w:] Arystoteles, Dzieła wszystkie, tłum. K. Leśniak, A. Paciorek, L. Regner, Warszawa 1990, s. 649. 
właściwości i przejawów nie różni się on od stanu, w którym znajdują się inne dziedziny nauki, szczególnie dziedziny humanistyczne, chociaż nauki przyrodnicze nie znajdują się w znacząco innej sytuacji. Ponadto nie będziemy tutaj zajmować się całokształtem zagadnienia w odniesieniu do całej teologii. Można więc jednoznacznie powiedzieć, że w dziedzinach historycznych, które także przeżywają swoje trudności, na ogół wiadomo, co jest do zrobienia. W tym miejscu interesuje nas bardziej szczegółowo sytuacja dotycząca teologii spekulatywnej, do której zaliczam przede wszystkim teologię fundamentalną i dogmatyczną (częściowo teologię duchowości i teologię moralną). Poniekąd w duchu Arystotelesa zajmę się trudnościami zauważanymi w teologii, które można wstępnie sprowadzić do dwóch najbardziej ogólnych, a mianowicie do zagubienia, a nawet zakwestionowania integralności oraz do niezdolności do integracji. To one zdają się dzisiaj kształtować duchową sytuację teologii w Kościele, a tym samym wyznaczać styl prac podejmowanych przez teologów.

Duchowa sytuacja czasów nie jest wynikiem przypadku czy zbiegu okoliczności ${ }^{7}$. Jeśli chodzi o genezę sytuacji duchowej naszego czasu, która znamiennie odzwierciedla się w nauce, w tym także w teologii, to trzeba powiedzieć, że należy jej szukać przede wszystkim w duchu oświecenia, na czele z dokonanym w jego ramach przewrotem immanentystycznym w gnozeologii. Nawiązując do konkretniejszych faktów - ośrodek interesującego nas problemu wiąże się z oświeceniowo-pozytywistycznym wprowadzeniem w życie idei "nowej nauki" - zaproponowanej jeszcze w okresie renesansu przez Giambatistę Vico, chociaż jego samego trudno posądzać o pozytywizm - której zasadniczy program operatywny sytuuje się w przeciwstawieniu między nauką i życiem ${ }^{8}$.

Nikt nie wyraził tego przeciwstawienia i jego konsekwencji tak dobrze i tak dobitnie, jak Nietzsche, myśliciel, który stoi u początków

7 Kwestię "duchowej sytuacji czasu” rozumiem w perspektywie propozycji Karla Jaspersa. Por. K. Jaspers, Die geistige Situation der Zeit, Berlin $1947^{5}$.

8 Por. moje opracowanie: Credo. Przedmiotowe wymiary aktu wiary, Tarnów 2002, s. 49-94. 
samoświadomości duchowej i nowego ukierunkowania teraźniejszości. Nazywa on naszą kulturę, która koncentrując się jednostronnie na praktyce, utraciła żywą relację z całokształtem życia ludzkiego, „pseudokulturą ruchomej encyklopedii". Stało się w niej prawdą to, co pisał hrabia Yorck do Wilhelma Diltheya: „Prawdziwą racją bytu każdej nauki jest oczywiście możliwość przełożenia jej na praktykę". Jeśli więc w naukach przyrodniczych i medycynie odniesienie do praktyki jest jeszcze bezpośrednie, to w naukach humanistycznych (duchowych - jak mówią Niemcy), do których należy także teologia, nie jest ono tak oczywiste. Nauki humanistyczne - jak podkreśla krytyka Nietzschego, do dzisiaj zachowująca swoją wartość - w zdecydowanym stopniu wraz $\mathrm{z}$ tak zwanym his toryz m em (pozytywizmem historycznym) utraciły swoje odniesienie do praktyki, redukując się do rejestrowania i opisu - pozornie obiektywnego - przeszłości, z których nie wypływa już autentyczna kultura, ale - mówiąc za Nietzschem - tylko jakaś postać wiedzy o kulturze.

Historyzm jako zapis i analiza przeszłości nie uwzględnia kwestii prawdy w jej całokształcie, a w ten sposób pozbawia refleksję naukową najpierw jej odniesienia do jednego centrum, czyli in te graln o śc i, a tym samym również jej uniwersalizmu. Tymczasem tylko prawda określa najpierw to, co decydujące, jednoczące i wspólne wszystkim ludziom. W oparciu o to samo założenie określa następnie także to, co stanowi jednoczące centrum każdej nauki, oraz to, co jest także wspólne różnym naukom. Dlatego właśnie w tym miejscu sytuuje się najbardziej problematyczna cecha duchowa naszych czasów, którą niemiecki historyk i teoretyk sztuki Hans Sedlmayr (1896-1984), analizując ewolucję sztuk figuralnych w XIX i XX wieku, słusznie uznanych za symbol i symptom epoki, określił jako „utratę centrum".

Efektem rezygnacji z pytania o prawdę, czyli o to, co stanowi ośrodek ludzkiego poznania, a zarazem wyznacza odniesienie do tego, co uniwersalne, jest przede wszystkim "fragmentaryzacja”

9 Por. H. Sedlmayr, Verlust der Mitte. Die bildende Kunst des 19. und 20. Jahrhunderts als Symbol der Zeit, Salzburg 1948. 
ludzkiego poznania, a nawet rozbicie wcześniej jednorodnych dziedzin naukowych, które zajmując się sektorami badawczymi, za najwyższą wartość uznają osiągnięcie jak najwyższej specjalizacji $\mathrm{w}$ ramach swojego przedmiotu. Specjalizacja sama w sobie nie jest oczywiście czymś negatywnym, gdyż pozwala wejść w głąb badanych kwestii i zjawisk, ale - jak okazało się w praktyce - problematyczny jest ogólny klimat antropologiczny, który jest jej efektem, a który nie tylko nie budzi w człowieku optymizmu, ale na dłuższą metę prowadzi do zamykania się dyscypliny naukowej samej $\mathrm{w}$ sobie, a więc w konsekwencji prowadzi do pewnej samowystarczalności i egoistycznego zadowolenia się sobą. Najwyższym wyrazem naukowości staje się $\mathrm{w}$ tym przypadku sprowadzenie pracy naukowej do analizy - na ogół mocno historyzującej - poszczególnych zagadnień, a najwyższym osiągnięciem staje się opracowywanie słowników, encyklopedii, leksykonów, przy czym równocześnie brakuje spójnych syntez rzucających ujednolicające światło na całość. Wywiera to oczywiście znacząco negatywne konsekwencje antropologiczne, które tak zdemaskował papież Jan Paweł II w encyklice Fides et ratio: „Wycinkowość wiedzy wiąże się z częściową wizją prawdy i prowadzi do fragmentaryzacji sensu, a przez to uniemożliwia współczesnemu człowiekowi osiągnięcie wewnętrznej jedności" (nr 85).

Ten klimat fragmentaryzacji udzielił się także teologii, która od swojego pierwotnego zainteresowania najwyższą Prawdą przeszła do zainteresowania się „prawdami”, a więc jest bardziej związana z zagadnieniami i ich badaniem metodą pozytywną (bardzo często typu monograficznego), niż z pytaniem się o prawdę samą w sobie. Widać to najlepiej w rozmaitych czasopismach teologicznych, w których autorzy opracowań zajmują się raczej tym, jak takie czy inne zagadnienie jest widziane przez jakiegoś autora, a brakuje zadawania pytań w odniesieniu do - mówiąc nieco scholastycznie - Prawdy pierwszej. Mamy tutaj dowód na to, że także teologia została dotknięta przez wspomnianą wyżej „utratę centrum”.

Ta fragmentaryzacja nauki i dziedzin naukowych, a następnie fragmentaryzacja w ramach poszczególnych dziedzin, jest oznaką braku, który może być zidentyfikowany właśnie jako brak integral- 
ności, której przyczyną jest zachwianie właśnie w odniesieniu do tego centrum, którym jest pierwsza Prawda.

Z problemem braku integralności, czyli wszechstronnego i centralizującego odniesienia do prawdy, wiążą się problemy dotyczące integracji, czyli spójnego ujęcia poszczególnych zagadnień, zarówno w ramach jednej i jednoczącej całości wielość aspektów, które uwzględnia dana dziedzina nauki - teologii, jak również w odniesieniu do całokształtu rzeczywistości naukowej, co wywołuje nieporozumienia, a nawet konflikty, jak pokazuje wymownie problem dyskusji na obecnością wydziałów teologii na uniwersytetach, będący przede wszystkim wynikiem redukcyjnego rozumienia relacji między nauką i wiarą. Bardzo wyraźnie ujawniła ten stan rzeczy polska dyskusja na ten temat, tocząca się na żenująco niskim poziomie zarówno po stronie przedstawicieli rozmaitych nauk, jak i po stronie samych teologów.

Trzeba więc najpierw stwierdzić, że brak integralności w nauce wyraża się brakiem inte gracji w e wn ętr z nej, można by powiedzieć „metodologicznej”, w ramach dyscyplin naukowych. Ta sytuacja odzwierciedla się bardzo wyraźnie w teologii jako nauce o Bogu jako pierwszej Prawdzie. Gubiąc odniesienie do tej pierwszej Prawdy, teologia gubi właściwego dla niej ducha syntezy, której wymownym wyrazem jest brak zainteresowania klasyczną kwestią, sformułowaną przez Akwinatę w formie pytania: Czy te ologia jest jedną n a u ką? W okresie średniowiecza ta zdawałoby się oczywista kwestia była studiowana i uzasadniana pozytywnie, stając się - właśnie $\mathrm{w}$ tym pozytywnym ujęciu - warunkiem postrzegania i uprawiania teologii, otwierając na widzenie kwestii w sposób całościowy i ciągle na szukanie takiej całościowości. Chodziło w niej o wypracowanie i zastosowanie czegoś w rodzaju jednej zasady architektonicznej, której celem było ciągłe „sięganie do centrum”.

Nadmiar dzisiejszych teologii, nazywanych niekiedy „dopełniaczowymi”, oraz kompletny brak refleksji nad jednością w teologii wyraźnie potwierdza, że integracja wewnętrzna jest czymś, czego brakuje w dzisiejszej teologii. Dowodzą tego bardzo zróżnicowane metody, funkcjonujące w ramach różnych dziedzin teologii, które do siebie po prostu nie przystają, a nawet przeciwstawiają się sobie. 
Brak integracji wewnętrznej widać w tym, że brakuje znaczących nowości w kwestiach systemów teologicznych. Nie jest prawdą, że skończył się czas systemów - skończyło się raczej zrozumienie dla ich potrzeby w ramach teologii. Wynika ono - jak słusznie zauważył wspomniany już Franz Rosenzweig - ze specyficznego rozumienia człowieka, jakie dzisiaj się rozpowszechniło. Systemy jawiły się jako coś koniecznego dla człowieka, gdy był on widziany jako „człowiek z piękną gałązką palmową”, który postępuje naprzód, korzystając z rozumu zdolnego do odniesienia zwycięstwa w każdej bitwie; gdy przeszło się do widzenia go przez pryzmat jego „kruchego i spopielonego ja", świadomego swojej radykalnej słabości i czasowości, jak również choroby swojej myśli i swojego rozumu w relacji do poznania prawdy, systemy nie tyle okazały się zbyteczne, co raczej niemożliwe do udźwignięcia ${ }^{10}$.

Konsekwencją tej drugiej wizji, w której rozum abdykuje wobec prawdy, jest także brak zwyczajnych, ale odznaczających się spójnością dobrze zorganizowanych syntez teologicznych - zarówno tych pisanych, jak i tych praktycznych, które powinny być wynikiem odbytych studiów teologicznych na różnych ich poziomach oraz $\mathrm{w}$ ramach różnych specjalizacji. Powoływanie się, i to nawet przez znamienitych teologów, na argument, że tę pustkę mają wypełnić katechizmy, do których ze wspomnianych wyżej powodów również podchodzi się niechętnie, jest dalece niewystarczające, ponieważ w katechizmach brakuje na ogół tego, co jest wyznacznikiem autentycznej teologii, czyli pogłębionego rozumienia.

Brak integracji wewnętrznej w teologii ma swoje dalsze i bezpośrednie przedłużenie $\mathrm{w}$ braku integracji egzystencjalnej, który wyraża się w tym, że teologia rzeczywiście traci swoje odniesienie do egzystencji i do życia. Następuje w tym przypadku rozejście się dróg prawdy i życia. Nie jest to tylko wynik nastawienia pragmatycznego czy też praktycznego, który charakteryzuje ducha naszych czasów, ale jest to nade wszystko powodowane nieumiejętnością odkrywania związków między prawdą i życiem, które

10 Por. F. Rosenzweig, „Cellula originaria” de La stella della redenzione, [w:] tegoż, La scrittura. Saggi dal 1914 al 1929, Roma 1991, s. 243. 
przecież mają charakter pierwotny. Uważa się więc, że prawda, aby była znacząca, musi być bezpośrednio i szybko przetłumaczona na praktykę, a $\mathrm{z}$ tego wynika uznanie praktyki za kryterium prawdy. Można więc powiedzieć, że duchowa sytuacja naszych czasów jest bardziej przeniknięta marksizmem, niż nam się na ogół wydaje.

Najbardziej problematyczne w tym miejscu jest poszukiwanie czegoś w rodzaju utożsamienia prawdy i życia poprzez odwoływanie się do prawdy praktycznej. Zapomina się w tym wypadku, że każda prawda ma wymiar praktyczny w sensie niejako pierwotnym - jak zauważali już Platon i Arystoteles - to znaczy tylko dlatego, że jest prawdą. Prawda jest zawsze znacząca dla człowieka, ponieważ dotyczy go jako istoty, która ze swej istoty nastawiona jest na poznanie. Zasadniczy problem wynika stąd, że po pozytywizmie za instancje pośredniczące między prawdą i życiem uznano technikę i technologię. Zapomniano, także w ramach techniki i technologii, że i w tym przypadku najwyższą instancją pośredniczącą jest mądrość. Ona jedyna jest zdolna do uczynienia prawdy teoretycznej prawdą egzystencjalną, czyli może dokonać jej uporządkowania za pośrednictwem odniesienia wszystkiego do najwyższej Prawdy, jak zresztą podkreślają najstarsze określenia mądrości. Z punktu widzenia teologii można powiedzieć, że niejednokrotnie kwestia praktyki została wprowadzona do niej w duchu, który jest odległy od ducha mądrości. Zresztą wymiar mądrościowy w teologii współczesnej został również w jakimś stopniu zapomniany, ustępując miejsca rozmaitym formom psychologizacji ${ }^{11}$.

Ponieważ - jak zostało zaznaczone - brakuje ogólnego odniesienia do prawdy w różnych dziedzinach nauki, dyscypliny naukowe zamiast otwierać się na siebie, zamykają się w sobie. Tak więc postulowana interdyscyplinarność pozostaje najczęściej tylko ogólnym postulatem metodologicznym, który nie jest wprowadzony w pełni do procesu badań naukowych, tak w teologii, jak i w wielu innych dziedzinach nauki. Stąd też w teologii nie dokonuje się autentyczny proces in tegracji interdyscyplinarnej. Tymczasem

11 Por. G. Cottier, Les chemins de la raison. Questions d'épistémologie théologique et philosophique, Saint-Maur 1997, s. 11-26. 
znajomość świata ma fundamentalne znaczenie dla teologii. Już św. Tomasz był świadom, że „znajomość stworzeń należy do nauki wiary chrześcijańskiej”"12 i że „poznanie stworzeń pozwala na przezwyciężenie błędów w odniesieniu do Boga"13. Do tego przekonania nawiązuje się także dzisiaj. Na przykład Max Scheler stwierdza w tym samym duchu: „Wszelka bowiem wiedza jest w ostatniej instancji wiedzą o Bogu i dla Boga"14.

Postulat ten wydaje się jeszcze bardziej aktualny dzisiaj, gdy poznanie świata rzeczywiście ma nowy zasięg. Nie oznacza to, że teolog musi wiedzieć wszystko, ale dzisiaj już wiadomo, że w żadnym przypadku nie można w teologii lekceważyć osiągnięć metodologicznych, do jakich doszły różne dyscypliny naukowe, jak również kwestii sytuujących się w szerokim kręgu nauk dotyczących „interpretacji" doświadczenia ludzkiego i wytworów działalności człowieka. Skoro teologia jest nauką o Prawdzie, a wiadomo, że prawda istnieje tylko jako interpretacja, to teologia musi być szczególnie zaznajomiona z całym bogactwem dyscyplin filozoficznych, które zajmują się tą problematyką. Słusznie mówi się o potrzebie uczynienia z intellectus fidei "aktu hermeneutycznego"15.

Gdy mowa o rozmaitych formach integracji w teologii, pojawia się oczywiście kwestia integracji funkcjonalnej, która weryfikuje się w dziedzinie dydaktyki. Teologia nie istnieje sama dla siebie, ale jest dyscypliną nauczaną w środowiskach dydaktycznych, jakimi są instytuty i wydziały naukowe. W przypadku integracji funkcjonalnej chodzi o zintegrowanie teologii w odniesieniu do celu, który określa jej nauczanie. To nauczanie dokonuje się $\mathrm{w}$ instytucjach dwojakiego typu - w instytutach naukowych związanych z seminariami duchownymi, a więc formującymi do kapłaństwa i życia zakonnego, oraz w instytutach, w których kształci się

12 Tomasz z Akwinu, Summa contra gentiles II, 2.

13 Tamże, II, 3.

14 M. Scheler, Formy wiedzy $i$ ksztatcenia, [w:] tegoż, Pisma $z$ antropologii filozoficznej i teorii wiedzy, przeł., wstępem i przypisami opatrzyli S. Czerniak, A. Węgrzecki, Warszawa 1987, s. 383.

15 C. Geffré, Un nouvel âge de la théologie, Paris 1987, s. 58. 
teologów, którzy mają zaangażować się w rozmaitych innych sferach działania - najpierw w stosunku do siebie, a potem w stosunku do Kościoła i świata.

Patrząc zatem na aktualne nauczanie teologii, trzeba stwierdzić, że w samej metodzie nauczania akademickiego nie bierze się pod uwagę tych dwóch celów nauczania, w wyniku czego "tak samo" naucza się teologii we wszystkich typach instytutów. Wynikiem takiego ustawienia dydaktyki teologicznej jest brak jego odniesienia do specyficznego znaczenia i wykorzystania teologii w odniesieniu do sytuacji, w których ma być potem wprowadzana w życie i przetwarzana. Cel wprawdzie nie uświęca środków, ale wydatnie pomaga w ich określeniu.

\section{PROPOZYCJE AKTUALIZUJĄCE}

Patrząc na trudności, które weryfikują się w ramach dzisiejszej teologii jako nauki, widzimy zarazem, że wskazują one konkretnie i bezpośrednio na wielorakie wyzwania, jakie stają przed teologami i czekają na podjęcie. Obejmują one bardzo wiele kwestii zarówno ogólnych, jak i szczegółowych. Wydaje się, że można je sprowadzić do czterech zasadniczych grup, które dotyczą:

- natury i metody teologii;

- treści, które mają decydujące znaczenie dla jej kształtu;

- kontekstu, który stanowi nieodzowną perspektywę ich podjęcia;

- funkcjonalności dydaktycznej teologii.

\subsection{NATURA I METODA}

Jak zostało wyżej wskazane, zasadnicza problematyczność dzisiejszej teologii sytuuje się na poziomie braku w niej wewnętrznej jedności, którego konsekwencją jest brak spójności poszczególnych traktatów oraz jej spójności jako całości. Z tego wynikają potem trudności dotyczące jej jednoznacznego odniesienia do praktyki chrześcijańskiej. Warto zaznaczyć, że kwestia ta została zauważona już w konstytucji apostolskiej Sapientia christiana papieża 
Jana Pawła II. Czytamy w niej: „Poszczególne zaś dyscypliny teologiczne tak winny być wykładane, by z racji wewnętrznych każdego przedmiotu i w powiązaniu $\mathrm{z}$ innymi dyscyplinami również filozoficznymi, jak też z naukami antropologicznymi jasno ukazywała się jedność całego wykształcenia teologicznego oraz by wszyscy byli skierowani do dogłębnego poznania tajemnicy Chrystusa, celem skuteczniejszego głoszenia jej ludowi Bożemu i wszystkim narodom" (art. $67 \$ 2)$.

Jak zostało zaznaczone, kwestia pierwotna zagubienia w dzisiejszym kontekście naukowo-kulturowym jedności w ramach różnych nauk, w tym także teologii, dotyczy zasadniczo zagubienia podstawowego przekonania o jedyności Prawdy czy też jedności w Prawdzie. Mając na względzie ten problem, Hans Urs von Balthasar zauważył: „Pytanie o prawdę w teologii jest pytaniem o jej przedmiot"16. Jest to uwaga bardzo słuszna i znajdująca niejako empiryczne potwierdzenie. Dzisiejsza teologia doświadcza zasadniczego deficytu właśnie w refleksji nad kwestiami dotyczącymi jej natury i metody, a więc tymi, które powinny zająć się także określeniem jej przedmiotu. Widać to choćby w częstym nierozróżnianiu między metodą i metodologią czy też w lekceważeniu tej kwestii w ramach nauczania teologii. W wyniku braku jedności w przedmiocie rozmywa się też jedność teologii.

Nie sposób tutaj objąć całości zagadnień, jakie zawierają się w postawionej kwestii. Wydaje się jednak, że w nauczaniu Kościoła została sformułowana bardzo wyraźna propozycja dotycząca sposobu ujmowania kwestii przedmiotu teologii. W ważnym dokumencie Kongregacji Nauki Wiary, którym jest instrukcja o powołaniu teologa w Kościele Donum veritatis, znajdujemy taką wypowiedź na temat przedmiotu teologii: „Przedmiotem teologii jest Prawda, żywy Bóg i Jego objawiający się w Jezusie Chrystusie plan zbawienia" (nr 8) ${ }^{17}$.

16 H. U. von Baltasar, Teologika, t. 2: Prawda Boga, tłum. J. Zychowicz, Kraków 2004, s. 27.

17 O współczesnych dyskusjach nad przedmiotem teologii i ich wpływie na jej nauczanie, por. J. L. Illanes Maestre, Teologíe y facultates de teología, Pamplona 1991. 
Pierwsza nowość tego stwierdzenia sytuuje się na linii przekroczenia dyskusji między ujęciem Tomasza z Akwinu i Bonawentury $\mathrm{w}$ odniesieniu do przedmiotu teologii, a mianowicie, czy jest nią Bóg - jak uważa teolog dominikański, czy Jezus Chrystus - jak uważa teolog franciszkański. Otrzymujemy tutaj ujęcie syntetyzujące, które nie jest tylko grą słów, ale propozycją jednoczącego spojrzenia na całość teologii, która otrzymuje ujęcie chrystologiczno-trynitarne.

Druga nowość - zdecydowanie ważniejsza - zawarta jest w odniesieniu do przedmiotu formalnego quod. Zdaje się więc, iż specyficznym aspektem, w którym powinna być traktowana rzeczywistość „Boga w Chrystusie” jest Prawda, to znaczy Bóg w Chrystusie, o ile jest Prawdą. W takim ujęciu Bóg jest ukazany jako jednoczący i ostateczny fundament tego, co prawdziwe, co weryfikuje się w relacjach między Bogiem i człowiekiem oraz - w oparciu o tę weryfikację - w każdym autentycznym mówieniu ludzkim. Co więcej - to, co prawdziwe, zostaje związane z kwestią zbawienia i jego urzeczywistnienia w Jezusie Chrystusie, a więc refleksji teologicznej zostaje nadany wymiar zbawczy i egzystencjalny, najbardziej praktyczny $\mathrm{z}$ chrześcijańskiego punktu widzenia. Wskazuje on zatem na potrzebę zdecydowanego pytania w teologii o to, ze względu na co Bóg jest dla nas i z nami, a zatem również w jaki sposób człowiek może i powinien wyrażać swoją odpowiedź na Boży plan zbawienia wypełniony w Jezusie Chrystusie, aby dojść do uczestniczenia w jego pełni.

Prawda ujęta w sensie chrystologiczno-trynitarnym ma także tę zaletę, że może zostać ustawiona w ścisłej relacji z pojęciem pełni, które w kontekście biblijnym ma zarazem wymiar uniwersalizmu, jak i ostatecznego spełnienia osobowego dla człowieka, który ją przeżywa. Całe to zagadnienie zasługuje na osobne przemyślenie.

\subsection{DECYDUJĄCE TREŚCI}

Jeśli chodzi o problem treści w zainteresowaniu teologicznym, to znajdujemy na ten temat wiele wypowiedzi u teologów współczesnych. Henri de Lubac pisał: „Trzeba wyjaśniać, ciągle wyjaśniać - 
nawet ryzykując zarzut, że wyjaśnienia te są nudne, rozwlekłe, szkolarskie i ciężkie - najprostsze pojęcia"18. Ważną uwagę na ten temat zapisał Joseph Ratzinger, odnosząc się do problemu zbytniego poszukiwania oryginalności w teologii, w wyniku którego naraża się na rezygnację z tych kwestii, które mają podstawowe znaczenie. Idąc zresztą po linii wypowiedzi wielu znaczących teologów współczesnych, stwierdza więc: „Szeroka przestrzeń na nowych polach była dobra i konieczna, ale tylko opierając się na założeniu, że wychodziłoby się z centralnego światła wiary i przez to światło było podtrzymywanym. Wiara nie ma trwałości sama przez się. Nie można jej po prostu zakładać jako czegoś już w sobie zamkniętego. Musi być przeżywana ciągle na nowo. A ponieważ jest aktem, który obejmuje wszystkie wymiary naszego życia, musi być także ciągle na nowo przemyśliwana i ciągle na nowo świadczona. Dlatego wielkie tematy wiary - Bóg, Chrystus, Duch Święty, łaska i grzech, sakramenty i Kościół, śmierć i życie wieczne - nigdy nie są tematami starymi. Są tematami, które ciągle przenikają nas coraz głębiej. Muszą na zawsze pozostać w centrum głoszenia, a więc i w centrum myśli teologicznej” ${ }^{19}$.

Kardynał Ratzinger w przytoczonej wypowiedzi zwrócił znacząco uwagę na bardzo istotny problem, który weryfikuje się w dzisiejszych badaniach teologicznych. Otóż - w porywie zmieniających się czasów, a wraz z nim pojawiających się pytań teologowie często zajmowali się z taką pasją interpretacją nowych zjawisk i problemów, że ich teologia straciła więź z podstawowymi tajemnicami chrześcijańskimi, „utraciła substancję wiary” ${ }^{20}$, i to do tego stopnia, że nierzadko po prostu przestała być teologią, stając się socjologią, psychologia itd. W wielu przypadkach rozmaite publikacje mogą być rozpoznane jako teologiczne tylko dlatego, że znajdują się w pismach nazywanych teologicznymi bądź sami autorzy za

18 H. de Lubac, O naturze i łasce, tłum. J. Fenrychowa, Kraków 1986, s. 32.

19 J. Ratzinger, W co wierzy Kościót?, [w:] Powstanie i znaczenie Katechizmu Kościoła Katolickiego w wypowiedziach papieża Jana Pawła II $i$ kardynata Josepha Ratzingera, wprowadzenie, tłum. i oprac. J. Królikowski, Poznań 1997, s. 117. G. Chantraine, Cosè la teologia, Casale Monferrato 1989, s. 43. 
takie je uznali. Trudno się potem dziwić, że teologia jest uznawana za pozbawioną związku z życiem chrześcijańskim.

Sensowne okazuje się więc przypomnienie, że teologia ma stale zwracać się do swojego centrum, które najlepiej jest określone przez Credo chrześcijańskie lub - w szerszym stopniu - przez katechizm. Jak się okazuje, w ramach „starych” kwestii, oprócz ich stałej aktualności dla wiary, może być jeszcze wiele do powiedzenia, a zatem rodzi się postulat pierwszorzędnego powrotu do teologii dogmatycznej, a więc tej, która zakorzenia się w dogmacie Kościoła jako podstawie wiary chrześcijańskiej. Jest bardzo znaczące, że wielu teologów, którzy całe swoje życie naukowe poświęciło badaniu rozmaitych „nowych kwestii”, deklaruje potrzebę takiego powrotu w teologii. Johann Baptist Metz, który zasłynął sformułowaniem i rozwijaniem tak zwanej teologii politycznej, doszedł ostatecznie do wniosku, że jedyną kwestią teologiczną godną teologa i uprawiania teologii jest kwestia Boga. Podobne znaczenie ma wypowiedź Jürgena Moltmanna - tym bardziej znacząca, że jako protestant należy do tradycji, która podpisuje się pod zasadą sola Scriptura - według którego za najważniejszą dyscyplinę teologiczną należy uznać dogmatykę.

Jeśli chodzi o aspekt treściowy teologii, to trzeba tutaj wskazać także na sposób jego podejmowania, ponieważ jesteśmy po wieku, który przyniósł wiele dyskusji na ten temat. Trzeba więc stwierdzić, że także ta teologia, która pozostała wierna kwestiom podstawowym, zawiera pewien problematyczny aspekt, który trzeba na nowo przemyśleć i odpowiednio potraktować. Chodzi mianowicie o wymiar spekulatywny teologii, którego ośrodkiem jest kwestia metafizyczna.

Niewątpliwą nowością teologii w II połowie XIX i w XX wieku było szerokie zwrócenie się do danych historycznych, na których opiera się wiara historyczna, której symbolem stało się określenie „historia zbawienia”. Jej efektem było doprowadzenie w teologii do konfliktu między wizją metafizyczną i wizją historyczną, z niejednokrotnie pojawiającym się radykalnym postulatem zbyteczności tej pierwszej. Pomijając szczegóły tej dyskusji, można już dzisiaj powiedzieć, że wizja metafizyczna broni się w swojej wewnętrznej 
konieczności; zarazem nastawienie i oparcie metafizyczne teologii nie oznacza zdrady historii zbawienia. „Historia implikuje jakąś metafizykę" - jak lapidarnie stwierdził Albert North Whitehead ${ }^{21}$.

Dzisiaj wiadomo zatem, że jeśli teologia ma pozostać wierna swojemu historycznemu punktowi wyjścia - jakim jest zbawcze wydarzenie Jezusa Chrystusa poświadczone przez Biblię - to musi przekraczać i zbliżać się ostatecznie do samego Boga, czyli traktować o Bogu sub ratione Deitatis. Chcąc zachować wierność i utrwalić treść praktyczną Ewangelii - którą jest zbawienie człowieka - musi stawać się scientia speculativa, a nie tylko jednostronnie scientia practica. Teologia musi traktować - jak wyżej zostało zaznaczone - o prawdzie, ale o prawdzie, która istnieje w sobie i powinna być badana w swoim bycie, zanim jeszcze zostanie określona jej użyteczność dla działania ludzkiego ${ }^{22}$.

Do takiego samego wniosku prowadzi konfrontacja, która miała miejsce $\mathrm{w}$ teologii między wizją metafizyczną i wizją eschatologiczno-egzystencjalną. Aby wydarzenie paschalne - jako wydarzenie eschatologiczne - mogło zostać uznane za ośrodek historii, który daje wszystkiemu podstawy i wszystkim kieruje, należy wyjść od stojącej u jego podstaw formuły metafizycznej: Jezus jest Chrystusem. Byt Jezusa - Syna Bożego - jest podstawowym wydarzeniem znaczącym, z którego wszystko inne wynika i od którego zależy. Właśnie Jego byt jako Syna Bożego sprawia, że Bóg i świat nie przeciwstawiają się sobie - ponieważ Bóg rzeczywiście działał w świecie. Jezusowe bycie Bogiem jest działaniem Boga Jego aktem, który stanowi podstawę „aktualności” zarówno teologii, jak i przepowiadania. Dopóki autentycznie opiera się na tym akcie, zachowuje obiektywne znaczenie i dotyczy każdego człowieka. Jeśli go porzuca, pozbawia się go znaczenia, nawet jeśli subiektywnie może jeszcze budzić czyjąś ciekawość.

Treści wiary muszą więc na nowo odzyskać to ujęcie, które opiera się na wizji metafizycznej, a to oczywiście zakłada powrót

21 A. N. Whitehead, Religia w tworzeniu, tłum. A. Szostkiewicz, Kraków 1997, s. 79.

22 Por. moje opracowanie: Credo, s. 230-235. 
do teologii spekulatywnej - kontemplacyjnej - która stanowi najwartościowsze dziedzictwo teologii chrześcijańskiej, a w jej ramach Bóg w Trójcy Świętej i Jezus Chrystus.

Warto zauważyć, że dopiero ujęta w tej perspektywie teologia może „stać się przygodą duchową”, jak sugestywnie wyraził się Klaus Demmer ${ }^{23}$, gdyż do stania się taką przygodą musi ona wprowadzić w świat, stanowiący miejsce, w którym ta przygoda się rozgrywa. A tym miejscem nie jest pozytywistyczny zbiór treści, o których mówi wiara, ale jest nią sama Rzeczywistość, która stanowi bazę własnego samorozumienia. A ta Rzeczywistość zostaje nam dana najpełniej na gruncie metafizycznym.

\subsection{KONTEKST}

Jak zostało już podkreślone, aktualną teologią jest ta, która traktuje poważnie kontekst, w którym przeżywa się i poświadcza wiarę, którą ona stara się rozumieć i uzasadniać. Trzeba od razu powiedzieć, że dzisiaj ten kontekst jest niezwykle złożony i wymagający, a zatem i wyzwania stające pod tym względem przed teologami rysują się jako bardzo znaczące. Aby je dobrze wyodrębnić, nieodzowne wydaje się nawiązanie w jego interpretacji i uwzględnianiu do uwag powiedzianych wcześniej w odniesieniu do przedmiotu teologii, gdyż z niego wynikają także pewne uwarunkowania rzutujące na kontekst, który trzeba będzie uwzględnić potem $\mathrm{w}$ teologii.

Dla teologa pierwszym kontekstem podejmowanych przez niego refleksji jest oczywiście kontekst wewnątrzkościelny, który stanowi jakby środowisko naturalne dla uprawiania przez niego teologii, on również wyznacza mu bezpośrednie zadania do podjęcia w ramach poszukiwań naukowych, skoro na teologu spoczywa powołanie eklezjalne, jak stwierdza wspomniany dokument Kongregacji Nauki Wiary Donum veritatis. Kwestia Kościoła jako środowiska teologicznego jest zazwyczaj podejmowana w ramach dość rozbudowanych

23 K. Demmer, Kann der Zölibat heute gelebt werden? Gedanken und agen aus Anlass der Bischofssynode, „Herder Korrespondenz” 46 (1990), s. 477. 
rozważań na temat eklezjalności teologii ${ }^{24}$. Często jednak ta eklezjalność nie przekłada się na odkrywanie i podejmowanie zadań stojących przed teologami, gdyż większość teologów wydaje się zajęta raczej rozwijaniem swoich zainteresowan.

W aktualnym momencie historycznym, patrząc od strony wewnątrzkościelnej, przed teologami stoi oczywiście zadanie rozumienia wiary, ale takie, które bezpośrednio i szeroko będzie uwzględniać kwestie nowej ewangelizacji i ekumenizmu, które to punkty odniesienia zdają się dzisiaj decydować zarazem o jej pastoralności, która zawsze jawi się jako postulat bardzo żywy w ramach poszukiwań teologicznych. Jeśli takie podstawowe zadania na początku nowego tysiąclecia stawiał Kościołowi papież Jan Paweł II - zarówno w sposób bezpośredni ${ }^{25}$, jak również propagując je za pośrednictwem proponowanej struktury i treści ogłaszanych przez siebie dokumentów - to teologowie nie mogą pozostawać obojętni na te wskazania, ale muszą je uznać za własne i wprowadzić do swoich badań. Chociaż pojawiają się już odpowiednie próby interpretacji tych wyzwań na poziomie metody teologii ${ }^{26}$, nie jest łatwo w sposób jednoznaczny określić, w jaki sposób można uwzględnić te zadania w teologii, ale zadanie uczynienia jej nauką bardziej ewangelizacyjną i bardziej ekumeniczną jawi się jako oczywiste. Nie oznacza to bynajmniej, jak daje się czasami słyszeć, dążenia do „uproszczenia” teologii pod względem językowym bądź treściowym. Niepowodzenia proponowanej kiedyś tak zwanej teologii kerygmatycznej najlepiej dowodzą, że takie rozwiązanie nie będzie

24 Por. Eklezjalny wymiar poznania teologicznego. Materiaty z sympozjum wykładowców teologii fundamentalnej, Kraków, 3-5.04. 2002, red. T. Dzidek, Kraków 2003.

25 „Dwa wielkie wyzwania, które w pewnej mierze zamykają w sobie całe życie dzisiejszego Kościoła, to nowa ewangelizacja i ekumenizm. Są one ściśle ze sobą związane, co jest szczególnie widoczne w krajach, w których żyje wiele różnych wspólnot chrześcijańskich": Jan Paweł II, Ewangelizacja $i$ ekumenizm, „L'Osservatore Romano” (pol.) 10 (1996), nr 2, s. 35.

26 Por. A. Staglianò, La teologia „che serve”. Sul compito scientifico ecclesiale del teologo per la nuova evangelizzazione, Torino 1996; J. L. Illanes Maestre, Desafíos teológicos de la nueva evangelización en el horizonte del terer milenio, Madrid 1999. 
skuteczne ${ }^{27}$. W ślad za papieżem można powiedzieć, że może tutaj chodzić o „odnowę form wyrazu”, gdyż ona pozwala, „aby można było przekazywać współczesnemu człowiekowi ewangeliczne orędzie w jego niezmienionym sensie" 28 . Wydaje się, że najlepszą drogą, która prowadzi do takiej odnowy, byłoby uprawianie teologii w oparciu o pierwotne rozumienie „katolickości” w odniesieniu do prawdy chrześcijańskiej. Oznacza ono, że tak należy przedstawiać prawdę chrześcijańską, by jawiła się jako prawda „dla wszystkich”. Zbyt często $\mathrm{w}$ interpretacji postawy katolickiej wychodzi się od przekonania, że katolickie jest to, co jest wspólne wszystkim a w takim ujęciu, biorąc pod uwagę jego ograniczoność i powierzchowność, raczej niewiele może być rzeczy autentycznie katolickich $^{29}$.

Jeszcze raz jawi się w tym miejscu pierwszorzędne znaczenie ujmowania teologii w jej odniesieniu do prawdy. Takie ujęcie może przyczynić się do „katolickiego” zaktualizowania wiary chrześcijańskiej, to znaczy ukazywania jej jako otwartej na i dla wszystkich. Dobrze pojęty uniwersalizm jest najlepszą apologetyką, która sprawia, że Kościół nie tylko najbardziej autentycznie czyta „znaki czasu”, ale także sam staje się autentycznym „znakiem czasu” dla świata.

Z tych założeń wynika zarazem, że prawda jest również tym, co decyduje o misyjności zarówno wiary, jak i samej teologii. Właśnie dlatego, że wiara chrześcijańska opiera się na prawdzie, jest ze swej natury misyjna, czyli zmierza do tego, by docierać do wszystkich ludzi. Joseph Ratzinger tak wyjaśnia aspekt misyjny wiary chrześcijańskiej: „Może ona być misyjna jedynie wtedy, gdy rzeczywiście przekracza wszystkie tradycje i jest wezwaniem do rozumu, zbliżaniem się do samej prawdy. Misyjna musi być także dlatego,

27 Por. C. Colombo, Teologia ed evangelizzazione, „La Scuola Cattolica” 78 (1950), s. 302-324.

28 Jan Paweł II, enc. Ut unum sint, 19.

29 O znaczeniu ekumenizmu dla rozwoju teologii por. D. Valentini, L'unità dei cristiani, fattore di rinnovamento teologico ed ecclesiale. Prospettiva cattolica, [w:] Fermenti nella teologia alle soglie del terzo millennio, s. 76-97. 
że człowiek jest przeznaczony do tego, by rozpoznawać rzeczywistość i także jego odpowiedź na pytania ostateczne ma być kształtowana przez prawdę, a nie jedynie tradycyjnie"30.

Te same uwagi dotyczą oczywiście ekumenizmu, który jest niczym innym, jak „drogą prawdy”, na którą wchodzą wyznania chrześcijańskie, aby szukać jedności. Warunkiem jedności wiary jest oczywiście komunia w prawdzie. Papież Jan Paweł II pyta w encyklice Ut unum sint: „W Ciele Chrystusa, który jest drogą, prawdą i życiem, któż mógłby uważać, że dopuszczalne jest pojednanie osiągnięte kosztem prawdy? (nr 18). A w odpowiedzi stwierdza: „Elementem, który decyduje o komunii w prawdzie, jest bowiem znaczenie tejże prawdy" ( $\mathrm{nr}$ 19).

Jeśli chodzi o eklezjalną misję teologii w sensie ad extra, to trzeba powiedzieć, że jej pierwszorzędnym punktem zainteresowania musi być współczesna kultura, oczywiście w bardzo szerokim znaczeniu. Chodzi o taką wizję kultury, która pierwszorzędnie obejmuje także cały zakres filozofii współczesnych, gdyż filozofia zawsze odgrywa w kulturze rolę pierwszoplanową i jakby organizującą, a drugorzędnie obejmuje także szeroko dzisiaj dyskutowany problem międzyreligijny. Ważnym kontekstem tego dialogu stają się dzisiaj także rozmaite nauki, z niebagatelną w nich rolą nauk przyrodniczych, ale wydaje się, że należy je w pewien sposób złączyć z filozofią, gdyż to ona odgrywa niezastąpioną pośredniczącą rolę $\mathrm{w}$ ich zbliżeniu do teologii, a więc pojawia się tutaj raczej problem filozofii nauki jako partnera dialogu dla teologii ${ }^{31}$.

Może zaskakiwać postawienie filozofii przed religiami, ale na sensowność takiego ujęcia zagadnienia wskazuje - po pierwsze historyczne doświadczenie Kościoła. Otóż pierwotny Kościół prowadził pierwszorzędnie dialog z kulturą starożytną, a nie prowadził dialogu z religiami starożytnymi ze względu na niebezpieczeństwo synkretyzmu. Po drugie - odniesienie do filozofii sytuuje się oczywiście na poziomie prawdy, a więc na tym poziomie, który teologia

30 J. Ratzinger, Prawda w teologii, tłum. M. Mijalska, Kraków 2001, s. 28.

31 Por. A. Dulles, El oficio de la teología. Del símbolo al sistema, Barcelona 2003, s. $157-170$. 
uznaje za podstawowy poziom podejmowanych przez siebie problemów. Na takie ujęcie zagadnienia wskazuje zresztą papież Jan Paweł II w encyklice Fides et ratio ${ }^{32}$.

Doświadczenie spotkania międzyreligijnego, oprócz wielu kwestii, zwłaszcza dyskutowanej dzisiaj kwestii możliwego znaczenia zbawczego religii niechrześcijańskich, stawia dzisiaj bardzo poważne zagadnienie treściowe, które sytuuje się na pograniczu teologii biblijnej i dogmatycznej, a mianowicie: jak ująć uniwersalne znaczenie Pisma Świętego właśnie w kontekście różnych kultur i religii. Jest to kwestia, która zdaje się z kolei warunkować określenie uniwersalnego znaczenia objawienia Bożego i Kościoła.

\subsection{NAUCZANIE TEOLOGII}

Teologia w swojej funkcji pozostaje niezmiennie scientia salutis i takie jest jej podstawowe znaczenie. Niemniej jednak teologia jako nauka może być nauczana w różny sposób zależnie od celu, który się przed nią stawia, nie tracąc w tym swojej tożsamości. Problem ten staje się szczególnie widoczny dzisiaj, gdy teologia stała się dyscypliną nauczaną w strukturze universitatis, a to oznacza także, że ta sytuacja określa pewne wyzwania odnośnie do sposobu jej nauczania. Cel nie uświęca środków, ale pozwala na ich odpowiednie określenie i dobór, mający na celu osiągnięcie wyznaczonego jej celu. Ta nowa sytuacja zdaje się proponować refleksje nad zasadniczą kwestią: czy ta teologia ma być nauczana w taki sam sposób jak teologia w seminariach duchownych, gdzie kształci się kandydatów do kapłaństwa, czy też powinno się jej nadać inne oblicze?

Ważne uwagi na ten temat możemy znaleźć w nauczaniu papieża Jana Pawła II, dla którego zarówno nauczanie teologii, jak i kwestia uniwersytetu ma znaczenie niemal centralne w ramach wskazań

32 Pozwolę sobie odesłać do mojego opracowania: Dialog z kulturami. Aktualność, trudności i kryteria, [w:] Wyzwania moralne przełomu tysiacleci, red. J. Nagórny, A. Derdziuk, Lublin 1999, s. 69-97; w wersji poszerzonej por. Dialogo con le culture. Attualità e criteri alla luce della Fides et ratio, „Annales Theologici” 15 (2001), s. 161-200. 
o charakterze intelektualnym, które rozwija i które przedstawia w różnych instytutach akademickich całego świata ${ }^{33}$. Z tego nauczania można więc dość łatwo wywnioskować, że istnieje na obecnym etapie rozwoju teologii potrzeba dwukierunkowego nauczania teologii. Jedno dotyczy wspomnianych już instytucji formujących do kapłaństwa i życia zakonnego. Teologia nauczana w takich instytutach powinna mieć przede wszystkim charakter formacyjny i duszpasterski, z naciskiem kładzionym na dyscypliny, które taki charakter posiadają, przy oczywistym w takim przypadku otwarciu jej na problemy świata, w którym żyje Kościół. Taka teologia powinna uwzględniać w sposób szczególny to, co kształtuje życie Kościoła i poszczególnych wierzących.

Jeśli chodzi o teologię ściśle uniwersytecką, która kieruje się przede wszystkim do ludzi świeckich albo dotyczy wyższych stopni specjalizacji, to powinna ona uwzględnić dwojaki cel, w którym wyrazi się jej służba eklezjalna ${ }^{34}$. Najpierw powinna to być teologia, której droga jest kwestia „światopoglądu” chrześcijańskiego, czyli taka, która uzdalnia do chrześcijańskiego interpretowania całokształtu zjawisk zachodzących w świecie oraz starająca się wykorzystywać te interpretacje tak, by kształtować chrześcijański obraz świata, a więc nie może ona abstrahować od zdrowo apologetycznego ujmowania zagadnień, skoro chrześcijanin ma wobec świata zdawać sprawę z nadziei, która go ożywia (por. 1 P 3, 15). Następnie powinna to być teologia, która poważnie i wszechstronnie traktuje dialog z innymi naukami, gdyż to w decydującym stopniu uzasadnia jej miejsce na uniwersytecie oraz może przyczynić się do wypełnienia tej luki w świecie naukowym, jakim jest brak podstawowego przekonania o „jedności wiedzy”. W takim znaczeniu teologia będzie mogła z kolei spełnić swoją rolę wychowawczą, społeczną, a nawet polityczną, którą niejednokrotnie już decydująco odegrała w historii.

33 Por. G. Tanzella-Nitti, Passione per la verità e responsabilità del sapere. Un'idea di università nel magistero di Giovanni Paolo II, Casale Monferrato 1998. Por. A. Dulles, El oficio de la teología, s. 171-186. 


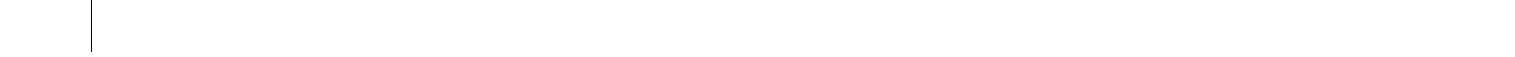




\section{ROZDZIAŁ III}

米

\section{Aktualność teologii apofatycznej?}

Funkcja apofatyczna - bądź negatywna - teologii polega na uwypukleniu zasadniczej nieadekwatności naszych przedstawień i naszych wypowiedzi w relacji do tajemnicy Boga. W apofatyzmie chodzi więc o krytyczne czuwanie nad wyznaniem wiary, mające na celu eliminowanie wszelkich dążeń zmierzających do utożsamienia Boga jako przedmiotu gramatycznego dyskursu religijnego z Bogiem żywym, który poprzedza słowo i przekracza wszelki dyskurs ludzki. Greckie słowo apophasis oznacza proces mający na celu podkreślenie tego drugiego aspektu. Teologia apofatyczna sytuuje swoje stwierdzenia na polu, które ogranicza się do pewności negatywnej wierzącego, czyli mówiącej, jak nie jest.

Ten aspekt teologii wrażliwej na swoje własne ograniczenia z bardzo wielu powodów nie tylko nie przestaje dzisiaj fascynować, lecz także znajduje się w centrum uwagi wielu zajmujących się religią, teologią czy językiem religijnym. Apofatyzm ujawnia więc dzisiaj nową aktualność, która zdaje się stanowić odpowiedź na schyłek systemów dogmatycznych, na rozwój lingwistyki, którego jesteśmy dzisiaj świadkami, na liczne kwestie związane z agnostycyzmem, ateizmem i tak zwaną „śmiercią Boga”, a w końcu zdaje się nawiązywać do myśli mistycznej - nie tylko chrześcijańskiej, ale także żydowskiej, muzułmańskiej czy też związanej z wielkimi religiami wschodnimi, która dzisiaj znalazła się w polu zainteresowań wielu dyscyplin naukowych. 
Patrząc na wypowiedzi dotyczące apofatyzmu, musimy powiedzieć, że często w to pojęcie włącza się arbitralnie przyjęte założenia teologiczne bądź wprowadza się treści sprzeczne między sobą i z samą doktryną chrześcijańską, w wyniku czego dochodzi do jego nadinterpretacji i nadużyć. Aby określić kierunki zainteresowania tym zagadnieniem i wyznaczyć jego ramy teologiczne, trzeba spojrzeć na tradycyjne ujęcie kwestii apofatyzmu w teologii chrześcijańskiej, szczególnie związanej z chrześcijańskim Wschodem, z którego to pojęcie się wywodzi, chociaż jest ono obecne również w tradycji łacińskiej, na co nie zawsze zwraca się uwagę bądź arbitralnie uznaje za nieautentyczne jego stosowanie w tej tradycji, na przykład u św. Tomasza z Akwinu.

\section{1. ŹRÓDŁA TEOLOGII APOFATYCZNEJ}

W oparciu o samą etymologię słowa apophasis można stwierdzić, że postępowanie apofatyczne rozróżnia między tym, co człowiek może powiedzieć i tym, czego nie wolno mu mówić, jeśli pyta się o swoją relację z Bogiem i o Boga w sobie. Święty Tomasz z Akwinu wyklucza, że w tej kwestii w ogóle może chodzić o jednoznaczne orzekanie ${ }^{1}$. Analogia atrybucji (przyporządkowania), która najlepiej określa charakter podejmowanych refleksji teologicznych, zakłada jako swoją istotną część negację wychodzącą z przekonania, że „sposób bycia przedmiotu nie jest sposobem bycia poznającego"2. Rzeczywiście zatem „celem poznania ludzkiego w kwestii Boga jest to, aby wiedzieć, iż nie zna się Boga”’. Apofatyzm oznacza więc, że wolność Boga wymyka się wszelkim próbom uchwycenia jej w sposób ostateczny przez wolność stworzoną.

Kwestia ma swoje zakotwiczenie biblijne, które dostrzegła dzisiejsza egzegeza, dzięki czemu szeroko zajmuje się kwestiami poznawalności i doświadczenia Boga. Współczesne próby odczytywania tekstu biblijnego bardzo mocno akcentują więc kwestie związane

\footnotetext{
Tomasz z Akwinu, Summa theologiae, I q. 13 a. 5.

Tamże, I q. 12 a. 7 ad 3.

Tomasz z Akwinu, De potentia, q. 7 a. 5 ad 14.
} 
z apofatyzmem, który charakteryzuje samą Biblię. Uznanie mistycznej inności Boga zakłada podwójną negację, a mianowicie, że po pierwsze - Bóg nie miesza się ze światem oraz - po drugie Bóg w żadnym wypadku jest niesprowadzalny do ludzkich obrazów. Odkrywając Boga jako całkowicie innego, czyli „świętego” - jak mówi o Nim Biblia - człowiek biblijny czuwa nad tym, by nie wejść na drogę dysponowania Nim jako przedmiotem, a w szczególności by nie zamknąć go w systemie swoich przedstawień.

Dla wypowiedzenia tego dystansu - nieprzystawalności - Boga i człowieka, geniusz żydowski odwołuje się do pojęć konkretnych, a nie metafizycznych. Czytamy u Deutero-Izajasza: „Prawdziwie Ty jesteś Bogiem ukrytym, Boże Izraela, Zbawco!” (Iz 45, 15) ${ }^{4}$. Człowiek może uchwycić tylko znaki Jego bliskości: płonący krzew, słup ognia, obłok, trzęsienie ziemi na Synaju. Gdy Mojżesz wyraża pragnienie oglądania oblicza Bożego, słyszy następującą odpowiedź: „Nie będziesz mógł oglądać mojego oblicza, gdyż żaden człowiek nie może oglądać mojego oblicza i pozostać przy życiu" (Wj 33, 20). A potem precyzuje: „A gdy cofnę dłoń, ujrzysz mnie z tyłu, lecz oblicza mojego nie ukaże tobie" (Wj 33, 23). Uznanie przejścia Boga, pewność Jego czynnej obecności oznacza zobaczenie „pleców” Boga - nie można Mu się „przyjrzeć” twarzą w twarz, gdyż oznaczałoby to już pewien typ posiadania, przywłaszczenia Go sobie i zatrzymania dla siebie. Teofanie biblijne są wielkimi manifestacjami niewidzialnego Boga. Wynika z tego absolutny zakaz wszelkich plastycznych przedstawień Boga ${ }^{5}$. Długa walka proroków z praktykami bałwochwalczymi doprowadzi ostatecznie - po powrocie z wygnania - do oczyszczającej centralizacji kultu w świątyni skoncentrowanego na shekina, która oznacza miejsce, w którym zamieszka Jego imię (por. Pwt 12, 11). Trzeba tutaj jednak zauważyć, że zakaz adorowania przedstawień Boga nie oznacza jednak zwrotu do kultu niematerialnego - czyli nie oznacza protestu przeciw kultowi zewnętrznemu i związanemu z tym, co materialne - jak również nie

4 Interpretatorzy żydowscy tłumaczą tę wypowiedź inaczej.

5 Por. Wj 20, 4; 34, 17; Kpł 19, 4; 26, 1; Pwt 4, 15-20; 27, 15. 
ma w nim eliminowania słowa wypowiadanego do Boga i o Bogu, a nawet następuje stopniowo jego znaczna promocja.

Powyższe uwagi prowadzą nas do zwrócenia uwagi także na inne teksty biblijne, szczególnie te dotyczące człowieka w ogóle i człowieka Jezusa. Nie możemy więc zapomnieć, że poemat kapłański o stworzeniu każe Bogu wypowiedzieć następujące słowa: „Uczyńmy człowieka na Nasz obraz, podobnego Nam" (Rdz 1, 26). Stanowią one centralny punkt antropologii biblijnej. Nowy Testament przedstawia Jezusa jako najwyższy obraz Boga niewidzialnego (por. 2 Kor 4, 4; Kol 1, 15; Hbr 1, 3). Kto Go widzi, widzi Ojca (por. J 14, 9). Mamy tutaj oczywiście do czynienia z oglądem „pośrednim” Boga. Wynika on z faktu, że oblicze Boga objawia się w uniżeniu, gdyż Jezus zjawił się w postaci Sługi (por. Flp 2, 6-8). Kenoza i krzyż - poprzez które Bóg przeznacza nas, „abyśmy się stali na wzór obrazu Jego Syna” $(\operatorname{Rz} 8,29)$ - wskazują na negatywność związaną z naszą kondycją jako stworzeń i grzeszników.

W XVII wieku Pierre de Bérulle zinterpretował wcielenie Słowa Bożego jako Jego tajemnicę wyniszczenia przez miłość: „natura Boża jest nieskończenie odległa od natury ludzkiej i będzie taką zawsze, jeśli miłość nie zjednoczy wewnętrznie natury Bożej z naturą ludzką"6. Chciał podkreślić, że w relacjach człowieka z Bogiem wszystko zależy od Bożej inicjatywy, szczególnie inicjatywy miłości, która jako jedyna pozwala na przekroczenie dystansu między Bogiem i człowiekiem. Wyrażając się filozoficznie, Hegel widział w tragedii Kalwarii nie tylko śmierć człowieka, lecz także „śmierć Boga”, która jako jedyna może dokonać przekroczenia granicy świata Boskiego i świata ludzkiego. Wielu filozofów wyprowadzi z tego jako konsekwencję przekonanie, że Ukrzyżowany wziął na siebie całe „naturalne” poznanie Boga, a więc stał się właściwą „teologią naturalną”. Początek tego ujęcia sytuuje się w aksjomacie Lutra: Crux Christi tota theologia est.

Niewidzialny Bóg żywy jest niepojęty dla ducha ludzkiego. Wychodząc od tej zasady, św. Atanazy utrzymywał więc, że kwe-

6 Cyt. za P. Cochois, Bérulle et l'École française, Paris 1963, s. 87. 
stia „jak?” w odniesieniu do wiecznego zrodzenia Syna przez Ojca musi być uznana za rzecz bezbożną. Jego współczesny, św. Efrem Syryjczyk, mocno i zdecydowanie odrzuca oskarżenie o to, że chciał racjonalnie uzasadnić niezgłębioną tajemnicę Boga. Na końcu epoki patrystycznej św. Jan Damasceński stwierdza: „Jest rzeczą niemożliwą powiedzieć, czym Bóg jest w swojej istocie. [...] On nie jest niczym z tego, co jest. Nie oznacza to jednak, że Go nie ma, ale że jest ponad wszystkim, co jest, i ponad samym bytem. To, co przekracza byt, przekracza także poznanie" . Na Zachodzie św. Augustyn, a potem teologia scholastyczna opierają się na przekonaniu, że człowiek może poznać istnienie Boga, ale Bóg w sobie pozostaje niepoznawalny. Święty Tomasz mówi więc: „Boga nie określa się jako nieistniejącego, tak jakby nie istniał w żaden sposób, ale dlatego, że będąc swoim istnieniem, przewyższa wszystko, co istnieje. Nie wynika z tego zatem, że nie może być poznany w żaden sposób, lecz że wykracza poza wszelkie poznanie, co znaczy, że nie można Go pojąć w pełni”" Absolutna inność Boga czyni więc z via negationis obowiązkowy sposób postępowania w dążeniu do rozumienia wiary.

\section{PODWÓJNE DZIEDZICTWO DIONIZEGO AREOPAGITY}

Właściwym twórcą teologii apofatycznej jest anonimowy autor traktatu O imionach Bożych, zredagowanego po grecku i znanego od VII wieku. Autor chrześcijański tego dzieła kształtował się w szkole Plotyna i Proklosa, a przedstawił się jako Dionizy Areopagita, uczeń św. Pawła (por. Dz 17, 34). Oprócz „imion Bożych” analizuje w perspektywie neoplatońskiej hierarchiczną strukturę kosmosu w dziełach: Hierarchia niebiańska i Hierarchia kościelna. Zstępującemu ruchowi, który emanuje z Boga i dochodzi aż do materii, odpowiada duchowe wstępowanie człowieka do Boga, które obejmuje trzy etapy: oczyszczenie, oświecenie i zjednoczenie. Ten ostatni etap pozwala duszy zjednoczyć się z Bogiem w „świetlistej ciemności”

7 Jan Damasceński, De fide orthodoxa I, 4: PG 94, 799-800.

8 Tomasz z Akwinu, Summa theologiae, I q. 12 a. 1 ad 3. 
kontemplacji. Taki jest przedmiot ostatniego traktatu, którym jest Teologia mistyczna. Te dzieła o charakterze teologicznym i duchowym ukształtowały podwójne dziedzictwo Dionizego, a mianowicie teologiczne i duchowe. Na to dwojakie dziedzictwo zwracamy tutaj uwagę, gdyż zbyt często jest ono niezauważane, w wyniku czego jego wymiar duchowy bywa mieszany z wymiarem ściśle teologicznym. Szczególnie często widzi się, jak wymiar duchowy zostaje bezkrytycznie nałożony na wymiar teologiczny, co służy wielu autorom do krytykowania racjonalności teologicznej. Najlepszym dowodem na konieczność odpowiedniego rozróżnienia jest to, że wybitni zwolennicy apofatyzmu byli równocześnie wybitnymi przedstawicielami teologii systematycznej, na przykład św. Bazyli Wielki czy św. Grzegorz z Nyssy.

Promieniowanie myśli Dionizego było bardzo dalekosiężne, zarówno na Zachodzie, jak i na Wschodzie, przede wszystkim za sprawą Maksyma Wyznawcy († 662) i Jana Szkota Eriugeny († ok. 877). W odróżnieniu od Maksyma, który skoncentrował się na dziedzictwie duchowym Dionizego, Szkot Eriugena, tłumacz na łacinę dzieł Dionizego, podjął i rozwinął głównie kwestie filozoficzne i teologiczne, które zarówno wywołały wiele kontrowersji, jak i - na dłuższą metę - okazały się decydujące dla rozwoju teologii średniowiecznej ${ }^{9}$. Podkreślając znaczenie Corpus Areopagiticum, nie można zapomnieć, że nie była to jedyna inspiracja dla teologii apofatycznej w średniowieczu. Podstawowa dla apofatyzmu idea Boga niepojętego, związanego z tym samym kręgiem myśli neoplatońskiej, oddziaływała także za pośrednictwem tekstów nawiązujących do starożytnego hermetyzmu, który znalazł wielu kontynuatorów, wśród których wybijają się Bernard Silvestre i Jan z Salisbury.

Co stanowi ośrodek traktatu Imiona Boskie? Dionizy tak formułuje zasadniczą trudność, którą bierze pod uwagę w swoim dziele: „A przecież jeśli Bóg Przewyższa każde rozumowanie i wszelką wiedzę i jest usadowiony wyżej niż wszelki intelekt i substancja, jeżeli obejmuje i skupia, i jednoczy, i poprzedza wszystko, sam pozostając

9 Por. E. von Ivanka, La signification historique du Corpus Areopagiticum, „Recherches de Science Religieuse” 36 (1949), s. 1-24. 
przy tym całkowicie nieuchwytnym dla wszystkiego, i nie podlega ani postrzeżeniom zmysłowym, ani wyobrażeniom, ani mniemaniom, nie można Go nazwać, zrozumieć, dotknąć i poznać - to jakże możemy napisać nasz traktat Imiona boskie, skoro udowodniliśmy już wcześniej, że nadsubstancjalna Boskość nie daje się wyrazić i że przerasta każde imię?"10. Odpowiedź na to pytanie zawiera jakby w zarodku cały późniejszy rozwój teologii apofatycznej. Boga w sobie nie mogą uchwycić ani słowa, ani myśli. Jednak, używając rozmaitych darów pochodzących od Niego, intelekty stworzone są w pewnej mierze w stanie okr eślić Prawdę, która przekracza wszelką prawdę: „Tej nadsubstancjalnej Boskiej Zwierzchności [...] nie nazwie nikt, kto kocha prawdę przenoszącą każdą prawdę, ani rozumem, ani mocą, ani intelektem, ani życiem, ani substancją, ponieważ Ona w sposób najwyższy przekracza każdą właściwość, ruch, życie, wyobrażenie, mniemanie, imię, rozum, myślenie, pojmowanie, substancję, spoczynek, trwanie, zjednoczenie, granicę, nieograniczoność - jednym słowem, wszystko, co jest wśród bytów"11. Pouczeni w ten sposób teologowie wielbią Boskość „jako bezimienną, i pod wszystkimi imionami”, a zarazem "ponad wszelkim imieniem"12. Paradoks wynika z faktu, że Bóg jest Stwórcą wszystkich rzeczy - przyczyną transcendentną, a więc nieznaną, ale równocześnie przyczyną uniwersalną, „stosownie więc do tego musi być sławiona i nazywana imionami wszystkich bytów"13.

W naszej epoce, w której nauki o języku stawiają podmiot niejako „naprzeciw” języka i w nowy sposób zadają pytania o relacje między słowem i rzeczą, pojawiająca się u Dionizego kwestia Boga „niepojętego", a więc i „niewymownego” zyskuje nową aktualność. Przy jej podejmowaniu trzeba pamiętać jednak o tym, że człowiek jest zarazem zdolny do wyznawania i wzywania Boga (kwestia „wielu imion"), chociaż są to akty słowne, w których zawarta jest projekcja

10 Pseudo-Dionizy Areopagita, Imiona boskie $(1,5)$, [w:] tegoż, Pisma teologiczne, tłum. M. Dzielska, Kraków 2005, s. 222.

11 Tamże, s. 223.

12 Tamże $(1,6)$, s. 223.

13 Tamże $(1,7)$, s. 225. 
jego bytu osobowego, jego podmiotowości i wolności. Koniecznym, choć - jak już zostało zaznaczone - ograniczonym zadaniem rozumu jest opracowanie pojęć i zastosowanie ich w ramach spójnego dyskursu. Przed racjonalnością teologiczną stoi więc zadanie oszacowania posiadanych narzędzi w relacji do dążeń, jakie wzbudza wiara $\mathrm{w}$ podmiocie.

Kwestia ta jest od początku, choć $\mathrm{w}$ różnym stopniu, obecna w teologii chrześcijańskiej, gdyż bardzo szybko została zauważona w ramach refleksji teologicznych. Wypracowano również wiele programów do jej systematycznego podjęcia. Ta trudna misja teologii na sposób aporii została sformułowana przez św. Bazylego Wielkiego: „Dążenie do uwielbienia Boga jest zakorzenione w sercu każdej istoty obdarzonej rozumem. Jednak wszystkie one są niezdolne do godnego mówienia o Bogu"14. Święty Augustyn powołuje się $\mathrm{w}$ tej kwestii na postępowanie mające raczej charakter heurystyczny: „Chcemy szukać Go, aby Go znaleźć; chcemy szukać Go, ponieważ znaleźliśmy Go. Jeśli chce się Go szukać, aby Go znaleźć, ponieważ jest ukryty, to chce się Go szukać, ponieważ znalazło się Go, ponieważ jest niewyczerpany"15.

Ze swej strony Dionizy proponuje metodę, którą można określić mianem „dialektycznej”. Stosując do Boga pojęcia zaczerpnięte z potocznego doświadczenia, teolog apofatyczny jest przede wszystkim w stanie zgrupować je w antynomie. Na drodze tego postępowania pojęcia korygują się wzajemnie, a duch ludzki jest chroniony przed pokusą zredukowania do zamkniętej wiedzy transcendencji Boga. Dziewiąty rozdział Imion Boskich ilustruje metodę w oparciu o cztery grupy pojęć: wielkość-małość, tożsamość-odmienność, podobieństwo-niepodobieństwo, spoczynek-ruch.

Wynika z tego, że propozycja teologii apofatycznej ma charakter paradoksalny, chociaż nie jest przedsięwzięciem „pustym” i beznadziejnym. Kiedy więc jasno dostrzega ograniczenia postępowania dyskursywnego, teolog stosuje ją w swoim specyficznym osądzie intelektualnym, a w ten sposób wchodzi na drogę prowadzącą go

14 Bazyli Wielki, Homilia XV, De fide, 1: PG 31, 464.

15 Augustyn, In Ioannis Evangelium tractatus, 63,1: PL 35, 1803. 
do Boga. Teologia apofatyczna nie polega więc na przemilczaniu ani na odwołaniu się do niepraktykowalnych pojęć i procedur. Tym, co $\mathrm{z}$ teologicznego punktu widzenia uzasadnia to postępowanie, jest przede wszystkim zagadnienie stworzenia, które wskazuje na istnienie relacji między Bogiem i człowiekiem-światem, a więc także pewną odpowiedniość między tymi dwoma nieprzystawalnymi rzeczywistościami. Jednak to nie uzasadnia jeszcze pewności, jaka mimo wszystko cechuje teologię. Poszukując odpowiedzi na to pytanie, dochodzimy do drugiego aspektu dziedzictwa dionizyjskiego, które stanowi jego nieodzowne dopełnienie i wyjaśnienie.

\section{DROGA MISTYCZNA}

Nie tylko krótki traktat Teologia mistyczna, ale cały długi traktat Imiona Boskie Dionizy podporządkowuje refleksji nad kontemplacją, która stanowi zresztą główne zagadnienie wszystkich jego dzieł, zgodnie z "prawem”, które sformułował w następujący sposób: „I tu także niech od początku naszych badań zobowiąże nas prawo zawarte w Piśmie Świętym, że prawd powiedzianych o Bogu nie ujawnia się $\mathrm{w}$ «zwodzących przekonywaniem słowach ludzkiej mądrości, lecz ukazując moc» daną świętym autorom przez Ducha Świętego, dzięki której dostępujemy w sposób niewyrażalny i niepojęty zjednoczenia z tym, co nie daje się nazwać i poznać, w stopniu znacznie większym niż wszystko, co możemy osiągnąć naszymi racjonalnymi i intelektualnymi mocami i energiami"16.

Apofatyzm poprzedza wzywanie Boga i do niego prowadzi oznacza to, że dzieło rozumu wpisuje się w tę wewnętrzną relację Boga i człowieka, której uprzywilejowaną formą jest modlitwa. Co więcej - w ramach tej relacji wiara "mówiona” do drugiej osoby może dostarczyć egzystencjalnej odpowiedzi na pytania, na które pozornie nie ma odpowiedzi. „Na początku każdej naszej czynności, a szczególnie gdy zaczynamy rozważać rzeczy boskie, należy zaczynać od modlitwy, nie po to, by przyciągnąć do nas tę moc,

16 Pseudo-Dionizy Areopagita, Imiona Boskie $(1,1)$, s. 217. 
która jest we wszystkim i nigdzie jej nie ma, lecz żeby rozmyślaniami o rzeczach boskich i pobożnymi prośbami oddać się w jej ręce i zjednoczyć się z nią"17. Trzeba więc stwierdzić, że - w ujęciu Dionizego - krytyka języka religijnego i praktyka modlitwy stanowią dwie komplementarne formy jednej drogi postępowania teologicznego. Dlatego właśnie jego myśl stała się pokarmem tak dla autorów duchowych i mistyków, jak i dla zawodowych teologów.

Oczywiście istnieją kierunki mistyczne w taoizmie, hinduizmie, buddyzmie, judaizmie i islamie, ale na terenie chrześcijańskim doświadczenie mistyczne łączy się ze strukturą doktrynalną wiary jako faktem pierwotnym. Doktryna chrześcijańska weryfikuje chrześcijańskie doświadczenie mistyczne. Ponieważ teologia Dionizego zbudowana jest na tym właśnie schemacie - oczywiście wraz z innymi autorami, takimi jak Orygenes, św. Grzegorz z Nyssy i św. Augustyn, chociaż pod wieloma względami została wyrażona bardziej bezpośrednio i systematycznie - jego wpływ okazał się determinujący w historii duchowości chrześcijańskiej.

Wychodząc od dzieł Dionizego, począwszy od XII wieku Europa, została objęta fermentem duchowym niemającym sobie wcześniej równego, który przedłużył się na całe drugie tysiąclecie. W kręgu bizantyńskim - wywołanym na tym samym gruncie - najbardziej wpływowym dziełem duchowym jest prawdopodobnie dzieło Symeona Nowego Teologa († 1022). Klasyczny okres mistyki wschodniej otworzył się na hezychazm, zilustrowany kategoriami dionizyjskimi przez Grzegorza Palamasa. W oczach tego ostatniego poznanie Boga jest umożliwiane przez dar Ducha udzielony stworzeniom. W tym założeniu odzwierciedla się pierwotne założenie teologiczne zastosowane w Corpus Areopagiticum.

$\mathrm{Na}$ Zachodzie wspomniany ferment duchowo-mistyczny został zapoczątkowany w łonie tradycji benedyktyńskiej i augustyńskiej, do której należą potem bardzo zróżnicowane osobowości: św. Bernard z Clairvaux, Hugo i Ryszard z opactwa św. Wiktora czy też Hildegarda z Bingen i Elżbieta z Schönau. Począwszy od XIII wieku, ruch zostaje

17 Tamże (3, 1), s. 240. 
zdominowany przez krąg franciszkański: św. Franciszek i św. Klara z Asyżu, św. Bonawentura, bł. Aniela z Foligno, Katarzyna z Genui oraz krąg dominikański: św. Dominik, św. Albert Wielki, św. Tomasz z Akwinu, Thierry z Freibergu, Mistrz Eckhart, Jan Tauler, Dominik Suzo, św. Katarzyna ze Sieny. Równolegle zrodziły się w kręgu flamandzkim nowe prądy duchowe: Béguines, Jan Ruysbroek, szkola z Groenendael, Devotio moderna i Frères de la vie commune. W Hiszpanii w szesnastym wieku duchowość karmelitańska inspiruje się św. Janem od Krzyża i św. Teresą z Ávili, autorami arcydzieł mistycznych. W następnym wieku szkoła francuska zdominowana przez Pierre’a de Bérulle’a odwołuje się do wcześniejszych źródeł, koncentrując swoją uwagę na tajemnicy Słowa Wcielonego.

Tym, co jest wspólne wszystkim tym grupom, jest nawiązanie do tradycji dionizjskiej; tym natomiast, co ubogaca jego pojęcie teologii apofatycznej, jest ścisłe nałożenie relacji interpersonalnej na racjonalne postępowanie dyskursywne, które ma konsekwencje zarówno duchowe, jak i teologiczne. Otóż człowiek „duchowy” wykorzystuje w swojej wędrówce do Boga zasoby swojej wyobraźni i swojej uczuciowości, ale z żywą świadomością inności i transcendencji, które są właściwe partnerowi Boskiemu, tej inności i transcendencji, które opisuje teologia. Zawsze Bóg jest tym, który podejmuje inicjatywę i który - jeśli zostaje przyjęty - obejmuje cały ludzki byt, dostarczając mu nowego typu poznania, zarazem doświadczalnego i kosztowalnego. Ale to nie wszystko - zjednoczenie, do którego zmierza mistyka, przechodzi przez doświadczenie „nocy”, która jest śmiercią dla zmysłów, grzechu, pasji ziemskich, czyli - mówiąc ogólnie dla tego wszystkiego, co nie jest Bogiem.

Noc mistyczna wskazuje potem na konieczność oczyszczenia naszych wyobrażeń i naszych pojęć, które tracą swoją adekwatność w doświadczeniu zjednoczenia z Bogiem. Mistrz Eckhart i jego dwaj główni uczniowie, Jan Tauler i Henryk Suzo, okazali się szczególnie wrażliwi na te formy oczyszczenia teologicznego, jakie odkrywa się w doświadczeniu duchowym. Rzeczywiście - jako dominikanie otrzymali najpierw formację, która uczyniła z nich teologów scholastycznych, o czym świadczą ich traktaty teologiczne. Potem, głównie jako kierownicy duchowi, doświadczyli radykalnej niewy- 
starczalności i nieadekwatności swoich zasobów intelektualnych wobec boskiego Absolutu przeżywanego przez człowieka duchowego. Zuchwałość języka ich traktatów duchowych i ich przepowiadania ma więc właściwie tylko jeden cel, a mianowicie - ukazać koniecznie niewystarczalność dyskursu teologicznego w osiągnięciu dostępu do etapu „zjednoczenia”, które jest celem człowieka duchowego. Interpretując tę kwestię, Yves Congar słusznie zauważa: „Gdy autorzy duchowi mówią: «Jestem niczym», «Stworzenie jest niczym», to nie zamierzają sformułować wypowiedzi metafizycznej odnoszącej się do bycia lub nie-bycia rzeczy, ale wyrazić minioną (należącą do przeszłości) postawę duchową"18.

Jako przykład można przytoczyć następującą wypowiedź Mistrza Eckharta: „Największą rzeczą, której człowiek może się wyrzec, jest wyrzekanie się Boga dla Boga; wyrzeka się on wszystkiego, co mógł wziąć od Boga, i wyrzeka się wszystkiego, co Bóg mógł mu dać, i wszystkiego, co mógł od Boga otrzymać. Wyrzekając się tego, wyrzeka się Boga dla Boga, a wtedy pozostaje mu Bóg taki, jaki istniejąc, jest sam w sobie, a nie na sposób, w jaki jest przyjmowany czy osiągany, lecz w bytowości, którą Bóg jest sam w sobie"19. Można zrozumieć, że takie sformułowania mogły budzić emocje i krytykę z powodu swojej oczywistej dwuznaczności. Jest jednak istotne w tej wypowiedzi to, że Eckhartowi nie chodzi na pierwszym miejscu o Boga „w Jego czystym bycie”, ale o Boga „otrzymanego" bądź „przyjętego", to znaczy o nadmierne zaufanie, jakie możemy przyznać zwyczajnym sposobom myślenia o relacji człowieka z Bogiem. Warto zauważyć, że wśród potępionych zdań Mistrza Eckharta nie ma zdań zaczerpniętych z jego traktatów teologiczno-scholastycznych, ale są wyłącznie zdania zaczerpnięte z jego kazań.

Ten wymóg przekroczenia czegoś w rodzaju powłoki czysto pojęciowej w ramach doświadczenia duchowego zostanie rozwinięty w swoich ostatecznych konsekwencjach przez bł. Henryka Suzo,

18 Y. Congar, Langage des spirituels et langage des théologiens, [w:] La mystique rhénane. Colloque de Strassbourg, 16-19 mai 1961, Paris 1963, s. 23.

19 Mistrz Eckhart, Kazanie 13: Qui audit me, [w:] tegoż, Kazania i traktaty, tłum. J. Prokopiuk, Warszawa 1988, s. 186. 
innego przedstawiciela mistyki nadreńskiej, który nie zawaha się zastosować do Boga pojęcia „nicości”20.

Wielu spośród współczesnych interpretatorów pism z omawianego kręgu mistycznego nie zauważa tego postępowania metodologicznego, gdy porównuje i łatwo utożsamia mistykę chrześcijańską na przykład z mistyką buddyjską. To samo dotyczy powoływania się na te pisma przez rozmaite kierunki agnostyczne bądź ateistyczne, zwłaszcza w kręgu tak zwanego "ateizmu religijnego".

Święty Jan od Krzyża jest tym autorem mistycznym, który zbiera dziedzictwo swoich poprzedników i nadaje doświadczeniu mistycznemu opis pełen subtelności i równowagi. W Nocy ciemnej pokazuje, w jaki sposób Boża inicjatywa dokonuje oczyszczenia zmysłów i ducha, przy czym również warto zauważyć, iż punktem odniesienia jego refleksji są dzieła Dionizego. Pisze więc na temat „ciemnej nocy kontemplacji”: „W tej nocy nie tylko ro zu m oczyszcza się ze swego światła i wola ze swoich odczuć, lecz również i pa mięć ze swoich rozważań i poznawań. Ona również może być bowiem unicestwiona pod względem wszystkich swych rozważań i poznawań, by się spełniło w tym oczyszczeniu to, co mówi o sobie Dawid: «A ja wniwecz obrócony byłem i nie wiedziałem». To «nie wiedziałem» odnosi się do owego zapomnienia i zaniku pamięci, spowodowanego wewnętrznym skupieniem, w którym kontemplacja pochłania duszę. Dla przygotowania i przysposobienia duszy według jej władz do rzeczy boskich i do zjednoczenia miłości potrzeba, aby najpierw została ona wraz ze swymi władzami pogrążona w tym Boskim i ciemnym duchowym świetle kontemplacji. Tym samym została ogołocona ze wszystkich przywiązań i pojmowań dotyczących stworzeń. Trwanie tego oczyszczenia uzależnione jest od jego intensywności. - Albowiem im częściej i bardziej wnikliwie wchodzi to światło Boże w duszę, tym więcej ją zaciemnia, opróżnia i unicestwia odnośnie do jej pojmowań i odczuć cząstkowych, dotyczących zarówno rzeczy ziemskich, jak i niebieskich. I z drugiej strony, jeśli to światło z mniejszą czystością i prostotą ją przenika, oczyszcza

20 E. Suso, Il libretto della verità, Milano 1997, s. 47. 
ją słabiej i mniej zaciemnia. Wydaje się rzeczą nie do wiary twierdzenie, że nadprzyrodzone i boskie światło tym bardziej zaciemnia duszę, im samo w sobie jest czystsze i jaśniejsze, i że również mniej zaciemnia, gdy jest słabsze. Można to jednak dobrze zrozumieć, jeśli się przypomni twierdzenie Filozofa [...], a mianowicie, że rzeczy nadprzyrodzone tym ciemniejsze są dla naszego zrozumienia, im same w sobie są jaśniejsze i oczywistsze"21.

To wymagające oczyszczenie duchowe, które opisuje i proponuje św. Jan od Krzyża, któremu często nadaje się zbyt jednostronnie miano „bierności”, nie ma nic wspólnego z propozycjami ucieczki od pojęć czy też łatwej rezygnacji z doktryny, propagowanymi przez rozmaite tandetne „mistyki”. Droga zjednoczenia łączy się z realizmem ewangelicznym, łącznie z jej wymiarem doktrynalnym, który stanowi jej podstawę i weryfikację. Także św. Teresa z Ávili, która osiągnęła niezwykły poziom życia kontemplacyjnego, nie przestała demaskować pobożności odcieleśnionej i opróżnionej z solidności doktrynalnej.

\section{ZASTOSOWANIE APOFATYZMU}

W ramach zbieżności i różnorodności wspomnianych tutaj kierunków duchowych lekcje, jakich nam udzielają, zdają się wszystkie zmierzać do takiego zastosowania apofatyzmu, który także dzisiaj może potwierdzić swój twórczy charakter w ramach racjonalności teologicznej. Teologia apofatyczna zakłada i rozwija zastosowanie takiej metody postępowania racjonalnego, która opiera się na czymś w rodzaju przeskoku epistemologicznego i hermeneutycznego.

Na takie zastosowanie wskazuje już analogiczny sposób postępowania, jaki jest stosowany w innych dziedzinach nauki. Można więc rozróżnić w nich dwa wielkie sposoby postępowania intelektualnego, które niejako dzielą dziedziny nauki na dwie wielkie rodziny duchowe. Pierwszą rodzinę określa metoda polegająca na przechodzeniu od tego, co nieznane, do tego, co znane - jest to logika

21 Jan od Krzyża, Noc ciemna, [w:] tegoż, Dzieła, tłum. B. Smyrak, Kraków 19864, s. $462-463$. 
opierająca się na zasadzie tożsamości i niesprzeczności. Druga rodzina - odwrotnie - rodzi się z postępowania, które ma charakter „różnicujący”. Chodzi w nim o uchwycenie różnicy, odwrócenie zagadnień, wywołanie napięcia czy przeciwstawiania, czyli „wprowadzenie dystansu", które dostarcza rozumowi ludzkiemu prawie nieograniczonej różnorodności punktów widzenia. możliwości konfrontacji i kryteriów analizy. Takie postępowanie, chociaż niesprecyzowane metodologicznie, okazuje się narzędziem bodaj najlepiej dostosowanym do złożoności rzeczywistości. Teologia apofatyczna $\mathrm{w}$ pewnym sensie wpisuje się $\mathrm{w}$ ten drugi typ postępowania.

Teoretycy dialektyki często odwołują się do procedury „przeskoku”, którą nazywają „momentem negatywnym”, oraz podają rozmaite przykłady jej pozytywnej weryfikacji w różnych dziedzinach życia i nauki. W historii odkryć naukowych można więc zauważyć, że decydujący postęp dokonuje się na ogół wtedy, gdy dokonuje się odrzucenia albo przynajmniej „wzięcia w nawias”, czyli zawiesza branie pod uwagę, wcześniejszych danych. Chodzi mianowicie o ujęcie zagadnienia jakby z przeciwnej strony. Genialny odkrywca zaczyna od zakwestionowania powszechnie przyjętych wyników i wyjaśnień, ponieważ przeszkadzają one obserwatorowi widzieć i rozumieć fakty w inny sposób. W taki sam sposób wybitni filozofowie Platon, Arystoteles, Kartezjusz, Kant czy Heidegger - oparli swoje filozofowanie na zdystansowaniu się od systemów poprzednich. Zrelatywizowanie jednych "prawd” umożliwiło im nowy dostęp do "prawdy”. Pewne rzeczy oczywiste przestają jawić się jako oczywiste, gdy po prostu bardziej przenikliwy niż inne umysł zdoła wykazać, że były one tylko hipotezami i że można je zastąpić hipotezami bardziej zadowalającymi. W ostatnim czasie zwłaszcza nauki o człowieku rozwijają się w oparciu o dokonywanie z uzasadnionych powodów przeskoków w proponowanych dotychczas wyjaśnieniach. We wszystkich więc dziedzinach wiedzy "moment negatywny” ożywia funkcję krytyczną rozumu, która jest wspólnym motorem innowacji filozoficznych, naukowych, technologicznych, artystycznych, a także teologicznych - co interesuje nas tutaj najbardziej.

Jeśli chodzi o tradycję apofatyczną, to trzeba od razu powiedzieć, że dokonuje ona przeskoku bardziej hermeneutycznego niż 
epistemologicznego, a mianowicie jej zasadniczy problem polega na rozróżnieniu między cele m ludzkiego dążenia religijnego, czyli poszukiwaniem sensu, a środkami stosowanymi przez rozum do jego ujęcia tematycznego, a więc chodzi o rozróżnienie między samym podmiotem i narzędziami, jakie ma on do dyspozycji. Uznanie "dystansu” między tymi dwoma „biegunami" hermeneutycznymi ma za zadanie strzeżenie zarazem specyficznego celu-sensu ludzkich dążeń religijnych oraz konsystencji struktur antropologicznych, które są dla nich typowe, w tym struktury poznawczej ${ }^{22}$. Wprowadzenie rozróżnienia nie oznacza oczywiście separacji i stwierdzenia nieprzystawalności, ponieważ podmiot i rozum przenikają się wzajemnie. Podstawowe znaczenie w tym wypadku ma doprowadzenie do tego, aby każda $\mathrm{z}$ tych dwóch instancji uznała relacje współzależności z tą drugą oraz starała się ją odpowiednio uporządkowywać w zależności od pojawiania się nowych okoliczności. W ten sposób definicje dogmatyczne a także teologia w ogóle - w niczym nie ograniczają eklezjalnego sensu wyznania wiary, czyli nie kwestionują, że celem, do którego ono ma prowadzić, jest żywy Bóg. Święty Tomasz z Akwinu ujmuje to bardzo przejrzyście: „Akt (wiary) wierzącego nie odnosi się do tego, co się wypowiada, ale do rzeczywistości (wypowiadanej)"23. Należąc do porządku środków, pozostają one po stronie tego, czym żyją świadomi wierzący, a więc nie naruszają ani nie ograniczają w niczym Boga. Problem polega więc na stwierdzeniu przeskoku hermeneutycznego w dogmatach - i w teologii - ale zarazem uznaje ich konieczność antropologiczną, gdyż bez nich transcendencja celu nie mogłaby być ani uchwycona, ani przywoływana jako instancja krytyczna.

Wśród środków używanych przez rozum zwróciliśmy już uwagę na pojęcia i pierwszoplanową rolę, jaką odgrywają w każdej teologii. Prawdę mówiąc, nacisk tradycji apofatycznej na relatywność języka pojęciowego w dużej części wyjaśnia się znaczącym wpływem filozofii greckiej. Można by przypuszczać, że ta problematyka nie miałaby

22 Problem, na który szczególnie wrażliwy był Karl Rahner.

23 Tomasz z Akwinu, Summa theologiae II-II q. 1 a. 2 ad 2. Por. KKK 170. 
takiej samej nośności w innych tradycjach kulturowych, na przykład w świecie semickim. Jakkolwiek by było, teologowie chrześcijańscy właściwie od początku nie przestają pytać się o ten przeskok, jaki zawarty jest w ich wywodach między tym, w co wierzy Kościół, czyli Bogiem żywym, a jego wrażeniem pojęciowym. Raz wskazują na ten przeskok, postępując drogą gromadzenia pojęć i stosowania pojęć z kręgu via eminentiae, by w ten sposób, odwołując się do bogactw języka, swoje wypowiedzi usytuować niejako na granicach jego możliwości, za którymi jest tylko Bóg. Innym razem, odwołując się do Dionizego, wykorzystują w języku teologicznym system antynomii pojęciowych, aby zasugerować, że wiara w jakiś sposób anuluje samowystarczalność każdego pojęcia wziętego w sobie. Jeszcze innym razem - i jest to przypadek bardzo częsty - aparat pojęciowy ustępuje bardziej lub mniej miejsca innym środkom wyrazu: obrazom, symbolom, metaforom itd. Pojawiają się w ten sposób nowe "przeskoki”, które ze swej strony domagają się dostosowanego traktowania hermeneutycznego. Jeśli mówi się dzisiaj wiele o fide ex visu, która ma mieć szczególny związek z obrazami, zarówno starożytnymi, jak i współczesnymi, to ta problematyka domaga się wypracowania odpowiedniej hermeneutyki religijnej obrazu, co oznacza, najprościej mówiąc, że patrzeć też trzeba umieć.

Mamy dzisiaj do czynienia ze zwrotem do apofatyzmu, który przynajmniej w części - jest spowodowany krytyką pojęć z punktu widzenia współczesnej lingwistyki i filozofii analitycznej. Krytyka pojęć pociąga za sobą oczywiście zakwestionowanie dyskursu. Coś podobnego spowodowała w średniowieczu logika i filozofia Arystotelesa. Teologia scholastyczna nie przyjęła wtedy na siebie zadania zdystansowania się wobec dyskursu, ale zaczęła przepracowywanie go pod kątem metodologicznym, które nie było oczywiście łatwe. Trzeba jednak zauważyć, że podjęcie tego zadania poszło dwutorowo - w sposób spekulatywny i w sposób duchowy. To autorzy duchowi byli pierwsi, ponieważ to oni wskazali na nowe drogi prowadzące do Boga - nowe w znaczeniu uwzględnienia nowego kontekstu kulturowego i społecznego. W dziedzinie przystosowywania się do nowych czasów i podejmowania nowych wyzwań autorzy duchowi i mistyczni mają więcej osiągnięć niż 
teologowie spekulatywni, gdyż ci drudzy zazwyczaj systematyzują i opracowują intelektualnie to, co ci pierwsi już przeżyli. Święty Tomasz z Akwinu byłby nie do pomyślenia, jeśli św. Dominik nie otwarłby nowych dróg w zmienionym świecie, którymi ten drugi mógł pójść. Doświadczenie historyczne potwierdza, że ludzie duchowi, a więc ci, którzy swoim życiem dokonali przeskoku między tym, w co wierzą i czym żyją, mogli wnieść znaczący wkład do otwarcia nowych dróg „wstępowania” duszy do Boga i w Bogu, pobudzając do refleksji nad sobą i swoją drogą życia. Inspirując się Biblią, mistycy nadreńscy i hiszpańscy w swoich refleksjach odwołali się między innymi do zapomnianych przez większość scholastyki rodzajów literackich, takich jak poematy, przypowieści, apologie, epopeje, a tym samym w sposób naturalny otwarli nowe perspektywy refleksji systematycznej.

Trzeba w tym miejscu także zauważyć, że u teologów apofatycznych uwaga zwrócona na ograniczenia rozumu dyskursywnego jest szczególnie ostra z powodu ich dużej wrażliwości na to, co możemy nazwać „duchem systemu”, czyli dążenie do zamknięcia wszystkiego, łącznie z Bogiem, w racjonalnym schemacie, często zaczerpniętym z jakiejś filozofii. Ta czujność szczególnie charakteryzuje mistyków późnego średniowiecza w ich postawie odrzucenia, pod wieloma względami przekornego, wielkich syntez teologicznych z XII i XIII wieku. Czegoś podobnego, choć bardziej systematycznie, dokonał później Kierkegaard w odniesieniu do systemu Hegla. Chociaż duński filozof nie może być zaliczony do teologów, nie jest mu obce to, czym jest teologia apofatyczna. Demaskuje on konsekwentnie heglowskiego ducha systemu, łącznie z krytyką ducha śmiertelnej powagi. Jego ironia jest szczególnie skutecznym egzystencjalnym sposobem praktykowania przeskoku hermeneutycznego. Jest na przykład godne uwagi to, że historyk idei użył schematów teologii negatywnej do ukazania genezy romantyzmu ${ }^{24}$.

Idąc jeszcze dalej, trzeba zauważyć, że to teologia apofatyczna przyczyniła się do ukształtowania takiego rozumienia języka, które

24 Por. G. Gusdorf, Du néat à Dieu dans le savoir romantique, Paris 1983, szczególnie s. 115-126. 
dystansuje się do teorii nominalistycznych. Po Dionizym podstawową kwestią w różnych wyrażeniach apofatyzmu jest kwestia tego, by wiedzieć, czy i jak należy mówi ć, kiedy uświadamiamy sobie mistyczną inność Boga. Wychodząc z tego przekonania, różni autorzy podkreślają znaczenie milczenia, które jest sposobem mówienia, a zwłaszcza jest warunkiem autentyzmu wypowiadanego słowa. Rzeczywiście, to milczenie poprzedza wolny wybór rezygnacji z pustego i banalnego słowa. Dyscyplina apofatyczna nie wyczerpuje się więc we wprowadzeniu rozróżnienia między słowami i rzeczami, ale ma charakter dogłębnie duchowy. Tym, czym teologia apofatyczna żywi się jak w swoim źródle, a w którym zapoczątkowuje się także intencjonalność świadomości, jest doświadczenie duchowe, które kładzie nacisk na żywą relację człowieka z B og i em. Otwiera się w ten sposób na doświadczenie mistyczne. Wyjaśnia się tutaj także miejsce, jakie zajmuje sfera afektywności w języku autorów duchowych. W takiej mierze, w jakiej zostaje dowartościowana relacja, emocje i uczucia wyrażają się z taką samą naturalnością, jak w tekstach biblijnych. Na przykład Pieśń nad Pieśniami, jest - po Księdze psalmów - księgą biblijną najczęściej cytowaną przez św. Jana od Krzyża. Takie wykorzystanie tekstu biblijnego znajduje więc swoje uzasadnienie w samej zastosowanej metodzie teologicznej. 


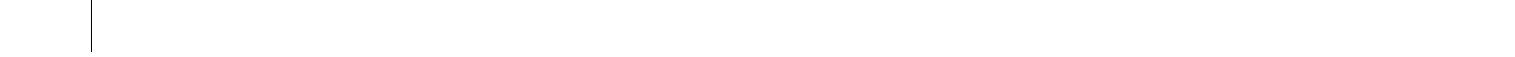




\title{
ROZDZIAŁ IV
}

\author{
米 \\ Teologia drogą do mądrości. \\ Metoda teologiczna \\ kardynała Josepha Ratzingera
}

\section{W DRODZE DO MĄDROŚCI}

„Ubi Ratzinger, ibi hilaritas - Gdzie Ratzinger, tam pogoda ducha" - głosi jedno z adagiów, które sformułowano w kręgu licznych uczniów i przyjaciół papieża Benedykta XVI. Ta pogodność daje się zresztą łatwo zauważyć, gdy czytamy rozmaite pisma teologa, biskupa i kardynała, a w końcu papieża z Bawarii. Ten łagodny i budzący zaufanie stan ducha, którym promieniuje on sam i jego dzieło, nie wynika bynajmniej z niezauważania przez niego burzliwych wyzwań i dotkliwych dramatów dzisiejszego świata oraz trudności, z którymi zmaga się Kościół. Kilka lat temu, w czasie jakiegoś spotkania, nawiązując do gorszących zjawisk mających miejsce w dzisiejszym Kościele, kard. Ratzinger z osobistym bólem i niezwykłą wprost szczerością, która zasmuciła słuchaczy, powiedział po prostu: „Jakże się cieszę, że jestem już stary; problemy zostają wam, młodym - współczuję wam". Na pewno nie mógł wtedy przypuszczać, że to jemu, "prostemu robotnikowi winnicy”, „niespodzianka Opatrzności", jak mówił papież święty Jan XXIII, powierzy na koniec jego ziemskiej wędrówki „troskę o wszystkie Kościoły” wraz 
z wszystkimi problemami, z którymi one się zmagają. A może właśnie dlatego, że bezpretensjonalnie i skromnie patrzył na swój osobisty wkład w dzieło kościelne, Opatrzność zleciła mu ten najcięższy urząd, jaki istnieje w Kościele i na ziemi?

Gdy powtarzamy: „Ubi Ratzinger, ibi hilaritas”, to chcąc nadać bliższą treść temu zdaniu, możemy je w znacznym stopniu zestawić z perfecta laetitia - doskonałą radością, o której mówi św. Franciszek z Asyżu i do której każe dążyć swoim uczniom. Jest w treści tego stwierdzenia zawarta idea dogłębnej i odważnej akceptacji świata, która pozwala zawsze widzieć w nim twórczą obecność dobroci człowieka i łaski Bożej, nawet wtedy gdy nieprzenikniony mrok i dotkliwe zimno, będące symbolami w pełni realnego zła, trzymają go w mocnym, niemal zniewalającym ucisku. Jest to coś w rodzaju obserwującego, a więc do pewnego stopnia dystansującego się patrzenia „z wysoka” - nie „z góry”! - na to wszystko, co dzieje się w człowieku, w Kościele i w świecie, patrzenia, które jest możliwe i twórcze zarazem, gdy nadaje się swoim doświadczeniom fundamentalne odniesienie eschatologiczne. Jest to coś w rodzaju konsekwentnej wędrówki „od Boga do Boga przez Chrystusa”.

Powyższe zestawienie, łączące hilaritas z perfecta laetitia, jest tym bardziej uprawnione, że św. Franciszek jest dogłębnie obecny w kluczowej pracy w dorobku teologicznym kard. Ratzingera, a mianowicie w jego rozprawie habilitacyjnej poświęconej teologii historii u św. Bonawentury, w której nie waha się uznać go - za Walterem Niggiem - za „średniowieczny obraz Chrystusa”. Mówiąc bardziej teologicznie, św. Franciszek jest dla niego osobową syntezą przeżywania więzi łączącej metafizykę, objawienie, historię i eschatologię. Tak samo uczynił zresztą Bonawentura, wielki scholastyk franciszkański, gdy doprowadził do znamiennego i organicznego przeniknięcia swojej teologii osobą i doświadczeniem Biedaczyny z Asyżu, czyniąc go jej ośrodkiem, natchnieniem i wypełnieniem.

Aby głębiej wejść w zaproponowany w tytule temat, trzeba jeszcze, przynajmniej ogólnie, sięgnąć do relacji zachodzącej między

1 J. Ratzinger, San Bonawentura. La teologia della storia, Firenze 1992, s. 32. 
teologią i mądrością. W średniowieczu toczyła się poważna i żywiołowa dysputa, uwarunkowana przemianami zachodzącymi w ówczesnej nauce i kulturze, zwłaszcza wpływem Arystotelesa, dotycząca tego, czy teologia jest bardziej wiedzą, czy mądrością. Święty Tomasz z Akwinu, wierny Arystotelesowi, zdecydowanie i w jego duchu bronił statusu naukowego teologii, chociaż równocześnie nie wahał się stwierdzić, że „wiedza święta jest w najwyższym stopniu mądrością", ponieważ pozwala uporządkować wszelką rzeczywistość i wszelkie doświadczenia w świetle najwyższej zasady, która je organizuje, czyli Boga. Również Bonawentura poszedł po tej samej linii, chociaż jego rozumienie mądrości jest bardziej osobowe, a tym samym bardziej bezpośrednie. Wynikało to z faktu, że był sceptycznie nastawiony do filozofii, zwłaszcza arystotelesowskiej, widząc niewątpliwe zamieszanie, które wywoływała. Nie wahał się jej nazwać w duchu apokaliptycznym „dymem wychodzącym z otchłani” ${ }^{2}$ czy też „nierządnicą”. Reagował zdecydowanie: „Nie można kochać nierządnicy i odrzucać przez to oblubienicy”, przy czym oblubienicą jest dla niego "mądrość-Chrystus” obecny w duszy. Dla Bonawentury mądrość jest takim uporządkowaniem wszelkiej rzeczywistości, które przede wszystkim pozwala „zakosztować Chrystusa", będącego jej źródłem, ośrodkiem i wypełnieniem, przenikającym każdą jej tkankę i każdy ruch. Patrząc na Franciszka, Bonawentura zadaje przenikliwe pytanie: „Na cóż służy wiele wiedzy, jeśli się mało kosztuje”. Nie odwołuje się do abstrakcyjnej zasady uporządkowania rzeczywistości, ale do żywej Osoby, która stanowi duchowy ośrodek wszystkiego, oraz do doświadczenia relacji z Nią w wielorakich miejscach ludzkiego poszukiwania Boga: stworzenie, Pismo Święte, wspólnota ludzka, oczekiwanie eschatologiczne itd. Utożsamiając się z tym rodzajem mądrości, kard. Ratzinger stwierdził w pewnej chwili, że w swojej teologii dąży nade wszystko do uwypuklenia „specyficznej instancji wiary chrześcijańskiej, która nie wskazuje po prostu człowiekowi drogi do tego, co wiecz-

2 Bonawentura, Collationes in Hexaëmeron VI, 5.

3 Tamże, XIX, 18. 
ne, ale do tego Boga, który działa w czasie i historii" więc o Boga, stanowiącego żywe centrum świata i życia, do którego człowiek może zbliżyć się osobowo w swoim zwyczajnym życiu i którego może uchwycić przez wiarę jako swojego Boga, a więc "zakosztować" Go, mówiąc językiem Bonawentury.

\section{CHRYSTOCENTRYZM}

W ten sposób dochodzimy do tego, co stało się i co jest istotne, w najbardziej tradycyjnym i autentycznym znaczeniu tego słowa, dla kard. Ratzingera. To, co dla niego jest rzeczywiście istotne, wyraża zdecydowanie następujące zdanie: „«Wystarczająca» jest tylko rzeczywistość Chrystusa" dziane w kontekście dyskusji nad teologiczną kwestią „materialnej wystarczalności” Pisma Świętego, czyli nad luterańską zasadą sola Scriptura, stanowi coś w rodzaju opcji fundamentalnej jego teologii i osobistego doświadczenia, które niejako posumował w konferencji wygłoszonej w Subiaco 1 kwietnia 2005 roku. Było to w przeddzień śmierci papieża Jana Pawła II i kilkanaście dni przed nowym konklawe ${ }^{6}$. Kilkakrotnie przypomniał tę opcję również w swoich ostatnich wypowiedziach. Jest to opcja, która - jak potwierdza wspomniana konferencja - ma swoje niewątpliwe źródła w Regule św. Benedykta, który daje swoim uczniom nad wyraz jednoznaczne wskazania: „Niczego nie przedkładać nad miłość Chrystusa” oraz: „Niech nic nigdy nie będzie dla nich [mnichów] ważniejsze od Chrystusa" ${ }^{8}$. W tym duchu, z niezwykłą mocą, mówił w czasie inauguracji pontyfikatu: „Dopiero wówczas, gdy spotykamy w Chrystusie żywego Boga, poznajemy, czym jest życie. [...] Nie ma nic piękniejszego, niż zostać dosięgniętym przez Ewangelię,

\footnotetext{
4 J. Ratzinger, San Bonawentura, s. 12.

5 K. Rahner, J. Ratzinger, Rivelazione e Tradizione, Brescia 1970, s. 41.

6 Por. J. Ratzinger, Europa Benedykta w kryzysie kultur, tłum. W. Dzierża, Częstochowa 2005, s. 41-72.

7 Benedykt, Reguła 4, 21.

8 Tamże, 72, 11.
} 
przez Chrystusa. Nie ma nic piękniejszego, niż poznać Go i dzielić się z innymi przyjaźnią z Nim"

Cała wędrówka duchowa, teologiczna i eklezjalna kard. Ratzingera jest energicznym, nieunikającym stwierdzeń i postaw apologetycznych uznaniem Jezusa Chrystusa za „efektywną rzeczywistość, która staje się wydarzeniem w objawieniu chrześcijańskim"10 ${ }^{10}$. On jest unicum rzeczywiście wystarczającym, gdyż może zapewnić nie tylko spójność logiczną, lecz także ostateczne zadowolenie spojrzeniu, które krytycznie wnika w rzeczywistość i stara się określić jej sens. $\mathrm{Z}$ tego powodu od samego początku kieruje się w swoim myśleniu ideą, że objawienie jest nieodłączne od Boga żywego i że dynamicznie zwraca się ono do żywej osoby, do której dochodzi. Ratzinger tak streszcza swoje teologiczne przekonanie w tej dziedzinie, do którego doszedł, studiując św. Bonawenturę: „«Objawienie» jest [...] pojęciem związanym z działaniem i oznacza działanie, poprzez które ukazuje się Bóg, a nie obiektywny wynik tego działania. Biorąc to pod uwagę, do pojęcia «objawienie» należy również zaliczyć podmiot otrzymujący objawienie: gdzie objawienie nie jest przez nikogo przyjęte, tam nie było żadnego objawienia, bo tam nic nie zostało ujawnione, odkryte. Sama idea objawienia zakłada kogoś, kto wejdzie w jego posiadanie"11.

Z tego ośrodka chrystologicznego w sposób bezpośredni wypływa ciągła uwaga kierowana na Kościół, czego dowodzi wyznanie: „Moim pierwotnym tematem był Kościół i ten wątek jest we wszystkim obecny"12. Jest on w jego rozumieniu nade wszystko żywym organizmem działającym w historii ludzi i narodów, zrodzonym z otwartego na krzyżu serca Chrystusa. Szczególne i wewnętrzne powiązanie między objawieniem Bożym i historią, którym żyje

9 Benedykt XVI, Przemówienie w czasie Mszy świętej z okazji inauguracji pontyfikatu (24 kwietnia 2005 r.), „L’Osservatore Romano” (pol.) 26 (2005), nr 6, s. 12.

10 K. Rahner, J. Ratzinger, Rivelazione e Tradizione, s. 40.

11 J. Ratzinger, Moje życie, oprac. W. Wiśniowski, Częstochowa 2005³, s. 85.

12 Tenże, Sól ziemi. Chrześcijaństwo i Kościót katolicki na przetomie tysiacleci. Z Kardynatem [...] rozmawia Peter Seewald, tłum. G. Sowiński, Kraków 1997, s. 55 . 
Kościół, wyrastające najpierw z osobistego doświadczenia wiary przeżywanej w rodzinie, w parafii, w seminarium, w posłudze kapłańskiej i biskupiej, stanowi jakby złotą nić splatającą także wszystkie pisma Ratzingera. To jest początek ciągłości i miara ewolucji jego myślenia, a równocześnie jest to ogólna cecha charakterystyczna jego metody teologicznej.

Spójrzmy teraz, jak się ona rozwija, i spróbujmy wydobyć jej zasadnicze elementy.

\section{KULTURA}

Pierwszy z tych elementów dotyczy - według kard. Ratzingera sposobu proponowania, w języku dostępnym dla dzisiejszego człowieka, przesłania wiary. Jest to taki sposób, który w żadnym wypad$\mathrm{ku}$ nie rezygnuje $\mathrm{z}$ danych dogmatycznych, a nawet nadaje im zdecydowane pierwszeństwo $\mathrm{w}$ wierze. To pierwszeństwo wynika z głębokiego przemyślenia kwestii prawdy i jej prymatu w życiu indywidualnym i społecznym człowieka, biorąc za punkt wyjścia współczesny sceptycyzm w tym względzie, obejmujący zarówno istnienie prawdy, jak i możliwości jej poznania. Kardynał zwierzał się: „Problematyka prawdy nie od razu miała dla mnie tak fundamentalne znaczenie. Dopiero w toku swej duchowej wędrówki wyraźnie zdałem sobie sprawę z pytania, czy - zważywszy na wszystkie nasze ograniczenia - nie uzurpujemy sobie czegoś, mówiąc, że możemy poznać prawdę. Zadałem sobie również pytanie, czy nie byłoby może lepiej, gdybyśmy w ogóle porzucili tę kategorię. Rozwijając te kwestie, pojąłem, że rezygnacja z prawdy niczego nie rozwiązuje, wprost przeciwnie, prowadzi do dyktatury dowolności. Wszystko, co wówczas pozostaje, jest tylko kwestią naszej decyzji i przedmiotem wymiany. Człowiek sam pozbawia się godności, gdy nie może poznawać prawdy, gdy wszystko jest właściwie tylko owocem indywidualnej czy zespołowej decyzji. Na tej drodze jasno zdałem sobie sprawę, że pojęcie prawdy nie może dla nas zaginąć, że musi pozostać główną kategorią - mimo wszelkich zagrożeń, mimo wszelkich niebezpieczeństw, które niewątpliwie implikuje. Że musi pozostać jako wymóg, który nie daje nam żadnych praw, 
wręcz przeciwnie, domaga się od nas pokory i posłuszeństwa, ale zarazem może nas zaprowadzić na drogę wspólnoty. W toku długich zmagań z sytuacją duchową współczesnego człowieka stał się dla mnie widoczny ów prymat prawdy, który, jak powiedziałem, nie daje się ująć czysto abstrakcyjnie i naturalną koleją rzeczy domaga się, by go oprawić w mądrość"13.

Łączność przesłania wiary z dogmatem-prawdą opiera się przede wszystkim na takiej koncepcji dogmatu, według której „oddziałuje on w strukturze teologii jako siła twórcza”, a nie jako „więzy, negacja i ograniczenie"14. Wymiar kulturowy związany z faktem chrześcijańskim nie jest więc pojmowany tylko zewnętrznie jako czynnik pośredniczący między objawieniem i historią, ale - zachowując należyte rozróżnienie - należy wewnętrznie do „ruchu”, przez który wydarzenie Jezusa Chrystusa, udzielając się w faktycznej rzeczywistości, stanowi wezwanie skierowane do człowieka i historii. W takim ujęciu teologia nie jest czymś odcieleśnionym, wyrwanym z kontekstu życia i abstrakcyjnym. Stara się ona, na ile to możliwe, tworzyć ścisłe relacje między wiarą chrześcijańską i całą teraźniejszością oraz najbardziej osobistymi pytaniami zadawanymi przez człowieka. Tworzenie relacji nie oznacza oczywiście łatwego uzgadniania doktryny z panującą mentalnością czy też rezygnowania z wiary na rzecz kultury i jej oczekiwań. Taka postawa prowadzi kard. Ratzingera do „wystawienia się” na krytyczną konfrontację z teraźniejszością zarówno Kościoła, jak i społeczeństwa. Może warto uzmysłowić sobie, że w dwóch ostatnich dziesięcioleciach - po papieżu Janie Pawle II - należy on do najbardziej krytykowanych ludzi w Kościele i poza nim za swoje poglądy teologiczne i formułowane diagnozy kulturowe. Ta jego konfrontacyjna i apologetyczna - w dobrym znaczeniu tego słowa - postawa nie obniża jakości naukowej jego wypowiedzi ani nie pomniejsza ich zdolności oddziaływania na dzisiejszy świat. Przeciwnie, jego wypowiedzi stają się jeszcze atrakcyjniejsze, będąc czytane nawet w kręgach głęboko laickich. Można się z nimi nie zgadzać, ale nie można ich ignorować.

\footnotetext{
13 Tamże, s. 56-57.

14 Tenże, Moje życie, s. 60 .
} 
Wymownego przykładu zastosowania teologii w powyższym znaczeniu dostarcza konferencja wygłoszona przez kard. Ratzingera w bazylice św. Jana na Lateranie 5 marca 1997 roku. Wychodząc od opowiadania o kuszeniach Jezusa, doszedł do kuszenia związanego z odczuwaniem głodu przez Jezusa. Bardzo poważnie traktuje głód Jezusa i problem głodu na świecie; stwierdza więc: „Czy jest coś bardziej tragicznego, coś, co w większym stopniu sprzeciwia się wierze w Boga dobrego i wierze w odkupiciela ludzi niż głód ludzkości? Czy nie powinna to być właśnie droga do uznania Odkupiciela przed światem i dla świata, że On daje mu chleb i zaspokaja głód każdego?"15. Takie pytania nie stają się bynajmniej dla niego okazją do sformułowania jakiegoś programu czy manifestu ekonomicznego i politycznego, w którym zaproponowałby spektakularne rozwiązanie tego problemu, a tym samym wzbudził powszechny aplauz. Nie wchodzi na drogę, którą niejednokrotnie idą także teologowie i pasterze, którzy byliby gotowi - za Wielkim Inkwizytorem Dostojewskiego - zamknąć kościoły, chwycić za karabin, zawiesić Ewangelię, a w końcu nawet zrezygnować z Chrystusa, by rzucić się w wir "skutecznego", jak twierdzą, rozwiązania ludzkich problemów. Ich dumne uzasadnienie takich postaw brzmi klasycznie: „Primum vivere, deinde philosophari”.

Ratzinger postępuje całkowicie odmiennie. Odpowiadając na sformułowane pytania, nie waha się zdecydowanie potwierdzić, wystawiając się na ostrą krytykę, stanowiska, którym żyje Kościół i które on uznaje za swoje. Mówi więc, powołując się na Alfreda Delpa, niemieckiego jezuitę męczennika: „Chleb jest ważny, wolność jest ważniejsza, ale czymś najważniejszym jest adoracja”16.

Cała wielka konfrontacja z „teologią wyzwolenia”, która naznaczyła początek urzędowania kard. Ratzingera w Kongregacji Nauki Wiary, dotyczyła właśnie tego problemu: co jest pierwsze, wiara i jej specyfika czy kwestia społeczna? Czy można zrezygnować z prawdy na rzecz praktyki wyzwoleńczej?

15 Tenże, Patrzeć na Chrystusa, by wybrać życie, [w:] J. Ratzinger, J. Królikowski, Z Chrystusem w historii. Rozważania chrystologiczne, Kraków 1999, s. 33.

16 Tamże, s. 34 . 
Udzielenie odpowiedzi na pytania i wyzwania stawiane przez rzeczywistość ludzką nie oznacza postawienia się immanentnie na poziomie tej rzeczywistości, aby tylko w jej świetle podjąć właściwe poszukiwania. Głoszenie wiary nie oznacza przystosowywania jej treści do wymagań i oczekiwań danego czasu. Wiara musi widzieć wszystko „odgórnie”, czyli mądrościowo, zapewniając we wszystkim prymat Boga i broniąc Jego najwyższych praw. Tylko w ten sposób staje się po stronie człowieka i można znaleźć adekwatne odpowiedzi na zadawane przez jego rzeczywistość pytania. W taki sposób kard. Ratzinger widzi drogę do skutecznej obrony człowieka, jego życia, kultury, ekonomii, polityki, a więc całej jego sfery społecznej, której w ostatnich latach poświęcił tak wiele refleksji i zabiegów. W tej perspektywie sytuuje się także jego bogata refleksja nad Europą i jej aktualną sytuacją duchową.

\section{PATRZEĆ NA CHRYSTUSA}

Drugim elementem charakteryzującym wrażliwość duchową kard. Ratzingera, a zarazem elementem jego metody teologicznej, jest to, co w pewnym sensie stanowi genezę tej metody. Można powiedzieć, że jest nim „zasada ascetyczna”, rozumiana jako mądrościowa synteza życia i wiary czy też życia zanurzonego w wierze. Ta asceza, czyli spojrzenie na rzeczywistość i podjęcie jej w świetle wiary, polega na osobistym wysiłku upodobnienia się do tajemnicy Jezusa Chrystusa pośród codziennych doświadczeń. Widać to wyraźnie w wypowiedziach kard. Ratzingera na temat wiary, modlitwy i liturgii. W Soli ziemi syntetyzująco wyznaje on: „Obcowanie z Bogiem dla mnie jest już koniecznością. Bo tak jak każdego dnia musimy oddychać, tak jak każdego dnia potrzebujemy światła i musimy jeść, tak jak każdego dnia potrzebujemy również przyjaźni, potrzebujemy niektórych ludzi, tak i obcowanie z Bogiem stanowi jeden z absolutnie fundamentalnych elementów mego życia. Gdyby Bóg przestał nagle istnieć, moja dusza nie miałaby czym oddychać" ${ }^{17}$.

17 J. Ratzinger, Sól ziemi, s. 9. 
To upodobnienie, do którego w sensie ścisłym jest powołany każdy człowiek, jest dla kard. Ratzingera dążeniem konkretnym, egzystencjalnym i systematycznym. Rodzi to u niego poczucie pewnego spełnienia, mimo że osiągnął rezultaty w innej dziedzinie niż zamierzał. Nie traci z tego powodu radości życia i coraz bardziej wnika w tajemnicę Jezusa Chrystusa, który sakramentalnie ofiaruje się człowiekowi, by kształtować jego codzienne relacje, okoliczności i zadania, które pozostają do spełnienia. Tylko upodobnienie do Chrystusa może uzasadnić takie wyznanie, w którym kardynał ustosunkował się do konieczności rezygnacji ze swojej pierwszej miłości, którą była teologia akademicka, na rzecz posługi pasterskiej. Tak mówi o „cenie”, którą za to zapłacił: „W moim przypadku ceną było to, że, by tak rzec, nie w pełni mogłem realizować swe dawniejsze plany, to znaczy istotnie współuczestniczyć myślą i słowem w wielkim duchowym dyskursie naszej epoki, rozwijać własne dzieło. Musiałem zejść na poziom realnych konfliktów i wydarzeń. Musiałem odsunąć na bok znaczną cześć swych zainteresowań i po prostu zająć się służbą, przyjąć ją jako swe zadanie. Musiałem się uwolnić od myśli, że oto trzeba coś bezwarunkowo napisać czy przeczytać. Musiałem uznać, że tu jest moje zadanie". I dodaje: „Tak, jestem pogodny, bo nie miałoby sensu buntować się przeciw sobie i swemu życiu. Myślę, że udało mi się jednak dokonać czegoś sensownego, jakkolwiek w innej dziedzinie, niż planowałem. I jestem naprawdę wdzięczny za to życie, które dał mi i ukształtował Bóg"18.

Aby uzasadnić sobie to przejście do nowego zadania i je przyjąć, kard. Ratzinger proponuje bardzo ciekawą teologię dotyczącą traktowania spełnianego aktualnie zadania, jakiekolwiek by ono nie było. Powinno być ono traktowane w perspektywie osobistej teraźniejszości, czyli stać się po prostu częścią życia w danej chwili, gdyż ona jest najważniejsza, bez nostalgicznego wracania do przeszłości i bez uciekania do przyszłości, które nosi na sobie znamię myślenia utopijnego, którego Ratzinger niemal organicznie nie znosi.

18 Tamże, s. 100. 
Tak pisze: „Teraźniejszość nie jest konkretną określoną datą, ona jest tym «teraz» jakiegoś życia, i to «teraz» może być długie albo krótkie. Dla mnie to, co rozpoczęło się przez nałożenie rąk podczas święceń biskupich w monachijskiej katedrze, ciągle jest jeszcze tym «teraz» mojego życia"19.

Dążenie do takiej syntezy, a nawet jej osiągnięcie, nie eliminuje oczywiście dramatycznych sytuacji i pojawiania się pytań, które niejednokrotnie głęboko naznaczyły życie kard. Ratzingera i jego refleksję, o czym świadczą różne pisma, zwłaszcza autobiografia Moje $\dot{z} y c i e$, ale - podobnie jak u św. Augustyna - to wszystko wyzwala $\mathrm{w}$ nim po prostu nowe pragnienia i otwiera na nowe poszukiwania. W wielu wypadkach dostrzegamy, że w swoich pismach rozmawia sam z sobą, życzliwie pozostawiając efekty tej rozmowy do dyspozycji czytelnika.

Wszystkie pisma kard. Ratzingera, a nawet sama jego koncepcja teologii, są naznaczone rysem osobistej zażyłości z Jezusem Chrystusem i realizmem ujmowania rzeczywistości, z jej dramatami i bólami, z jej radościami i nadziejami. To wyjaśnia, dlaczego obca była dla niego neoscholastyka, z której ironizuje, wspominając swojego profesora filozofii Arnolda Wilmsena: „Udał się [...] do Rzymu i tam w filozofii tomistycznej odnalazł to, czego szukał. Teraz jednakże sam nie wydawał się być poszukiwaczem, lecz - stając wobec stawianych mu pytań - namiętnym obrońcą tego, co już odnalazł. My zaś, jako ludzie młodzi, stawialiśmy wiele pytań"20. Jako osobistą, dostosowaną do swojej wrażliwości, obrał inną drogę: „Dlatego zawsze czymś bardzo ważnym była dla mnie egzegeza. Nie potrafię sobie wyobrazić czysto filozoficznej teologii. Punktem wyjścia jest słowo. Punktem wyjścia jest to, że wierzymy słowu Bożemu, że próbujemy je rzeczywiście poznać i zrozumieć, że staramy się je potem myśleć za wielkimi mistrzami wiary. Stąd moja teologia stoi pod znakiem Biblii, a także pod znakiem ojców Kościoła, zwłaszcza św. Augustyna" ${ }^{21}$.

\footnotetext{
19 Tenże, Moje życie, s. 138.

20 Tamże, s. 51.

21 Tenże, Sól ziemi, s. 69.
} 
W tym kontekście zrodziło się także głębokie przekonanie kard. Ratzingera, że teologia jest ściśle związana z osobistą świętością teologa - że jest jej właściwym środowiskiem i warunkiem skuteczności posługi myślenia. Być może wpłynął na to ujęcie Hans Urs von Balthasar. Ratzinger zauważa, że w historii teologia sięgnęła swoich szczytów wtedy, gdy umiała czerpać z żywego źródła świętości, czego wymownym dowodem są głębokie więzi łączące teologów ze świętymi. Święty Antoni opat był bijącym źródłem teologii dla św. Atanazego, św. Benedykt dla św. Grzegorza Wielkiego, św. Franciszek - jak już wspomniano - dla św. Bonawentury, św. Jan Kasjan i św. Dominik dla św. Tomasza z Akwinu. Dlatego Ratzinger ze spokojem wyznaje: „Nigdy nie starałem się stworzyć własnego systemu, jakiejś odrębnej teologii. Swą myślą chcę po prostu podążać za wiarą Kościoła, co przede wszystkim znaczy: podążać za wielkimi myślicielami wiary - właśnie to można nazwać specyfiką mojej teologii"22.

Na tym tle wyjaśnia się pierwszeństwo dane przez kard. Ratzingera soteriologii oraz pewna jej specyfika. Wykład soteriologiczny nie jest dla niego rozważaniem warunków i możliwości, które sprawiły, że Bóg mógł zbawić ludzkość, ale oznacza mówienie o moi m-naszym zbawieniu. Mówienie o łasce nie oznacza szukania "egzystencjału nadprzyrodzonego", które również zachowuje swoją wartość, ale jest spojrzeniem na Chrystusa i przyjęciem ofiarowanego człowiekowi życia, aby wprowadzić go na drogę szukania upodobnienia do Niego. Eschatologia nie jest dla niego odległym wypełnieniem losów świata, ale osobistym i osobowym przeznaczeniem konkretnego człowieka, które spełnia się dzień po dniu.

\section{WERYFIKACJA EKLEZJALNA}

Jeśli genezą metody teologicznej kard. Ratzingera jest osobiste upodobnienie do Chrystusa jako konkretna zasada ascetyczna, to Kościół stanowi dla niego - w ramach tej metody - kryterium

22 Tamże, s. 55-56. 
weryfikujące autentyczność refleksji i działania chrześcijańskiego. Stąd tak formułuje swoje Credo, które właściwie jest tylko streszczeniem Credo kościelnego: „Wierzę w Boga w Chrystusie, obecnym w Kościele, [...] w tym kierunku staram się prowadzić swoje życie"23.

Kościół jest rozumiany przez niego jako miejsce wydarzenia, które dokonuje się w historii: „Pamięć Kościoła, Kościół jako pamięć, jest więc miejscem wszelkiej wiary. Kościół przeżywa czasy, z wzlotami i upadkami, zawsze jednak jako wspólna przestrzeń wiary”24. W tym znaczeniu Kościół nie jest zgrupowaniem ludzi, które wywodzi się z jakiejś nieokreślonej bliżej przeszłości. Należy do samego wydarzenia objawienia, wypełnionego w Jezusie Chrystusie. Kościół jest - jak wskazuje Pawłowe określenie „Ciało Chrystusa” - komunią wiernych oraz „reprezentuje obecność i trwałą stałość - byt Chrystusa w świecie" ${ }^{25}$. W tym Ciele Chrystus zwołuje ludzi i gromadzi ich w lud, czyniąc ich uczestnikami swojej odkupieńczej mocy i swego boskiego życia. Nawiązując do tego przekonania w czasie inauguracji pontyfikatu, już jako Benedykt XVI mówił: „My wszyscy jesteśmy wspólnotą świętych, my - ochrzczeni w imię Ojca, Syna i Ducha Świętego, my - żyjący dzięki darowi Ciała i Krwi Chrystusa, poprzez który On pragnie nas przemienić i upodobnić do siebie. Tak, Kościół jest żywy"26. W trakcie tego przemówienia, budząc entuzjazm wśród zebranych na Placu św. Piotra, jeszcze kilkakrotnie powtórzył: „Kościół jest żywy”.

Właśnie tak rozumiany Kościół stanowi kryterium weryfikacji myślenia i działania. Staje się to jasne, gdy zestawimy Kościół z kategorią doświadczenia. Ratzinger często mówi o „Kościele jako środowisku doświadczenia" ${ }^{27}$. Pojęcie doświadczenia wyprowadza on ze studium wielkich ojców i doktorów Kościoła, dokonując jego

\footnotetext{
23 Tamże, s. 99.

24 Tenże, Elementi di teologia fondamentale, Brescia 1986, s. 20.

25 K. Rahner, J. Ratzinger, Rivelazione e Tradizione, s. 41.

26 Benedykt XVI, Przemówienie w czasie Mszy świętej z okazji inauguracji pontyfikatu, s. 10.

27 J. Ratzinger, Elementi di teologia fondamentale, s. 90 (por. s. 81-95).
} 
konfrontacji z współczesnymi filozofami i teologami. To doświadczenie obejmuje najpierw ciągłe zwracanie uwagi na sposób, w jaki problemy, kwestie, pytania, oczekiwania, nadzieje i lęki człowieka sytuują się w konkretnej sytuacji, w której się znajduje. Stwierdza następnie, że w Kościele temu doświadczeniu przysługuje pewne pierwszeństwo w stosunku do instytucji i praw. Ta koncepcja Kościoła jako środowiska doświadczenia pozwala Ratzingerowi ujmować Kościól jako „podmiot”, który działa w historii oraz weryfikuje dobroć wszelkiego myślenia i wszelkiej praktyki wierzących.

W tym kontekście sytuuje się także wielka i doniosła egzystencjalnie kwestia Eucharystii, która stanowi ośrodek refleksji eklezjologicznej kard. Ratzingera. Celebracja eucharystyczna pozwala najpełniej i najskuteczniej uchwycić naturę Kościoła. Opiera się ona, jak przypomina od początku i z naciskiem geniusz chrześcijański, na pojęciu sakra me ntu. Właśnie dlatego, że doświadczenie eklezjalne jest doświadczeniem sakramentalnym, „raz na zawsze” wydarzenia Chrystusa spotyka się z człowiekiem w każdej epoce historycznej, w każdym „dzisiaj”. W sakramentach Kościół znajduje i przeżywa pełne aktualizowanie się logiki wcielenia, a równocześnie jego ciągłe odradzanie się w sercu osoby. W sakramentach urzeczywistnia się współczesność wiecznej prawdy, którą jest Bóg, oraz tej natury dramatycznej, skończonej, chociaż uzdolnionej do uchwycenia tego, co nieskończone, którą jest człowiek. W każdej chwili historii prawda chrześcijańska jest współczesna z wolnością człowieka, któremu jest głoszona. To jest racja, która sprawia, że wiara nie jest obca wobec człowieka jakiejkolwiek epoki historycznej. „Rozwód” między Bogiem i człowiekiem weryfikuje się tylko tam, gdzie dokonuje się jakiejś redukcji istoty chrześcijaństwa bądź się nią manipuluje.

Kardynał Ratzinger nie waha się więc mówić o ostateczności, uniwersalności i pełni wydarzenia Jezusa Chrystusa oraz o jego zdolności dokonywania przewartościowania we wszystkim. Wyjątkowo widać to przekonanie w jego traktacie poświęconym eschatologii. Bardzo wyraźnie widać to przekonanie również w rozważaniach Ratzingera na temat kultury. Kultura jest dla niego owocem czegoś w rodzaju „zderzenia” z rzeczywistością podmiotu eklezjal- 
nego, który przeżywa wcielenie każdego ochrzczonego w Jezusa Chrystusa. W takiej wizji kultury treści i podmiot osiągają całe swoje właściwe znaczenie w doświadczeniu. Można adekwatnie przekazać treści, gdy są one przeżywane przez podmiot, który je ma i przekazuje. W odniesieniu do posługi kapłańskiej kard. Ratzinger tak wyjaśniał tę zasadę: „Czytałem anegdotę o prawosławnym księdzu, który powiedział: Tak się staram, a ludzie mnie nie słuchają, śpią albo w ogóle nie przychodzą, widocznie coś źle mówię. Przypadek ten egzemplifikuje doświadczenia, które stają się udziałem również innych kapłanów. To bardzo ważne, by sam kapłan miał, dzięki żywemu słowu, wewnętrzny stosunek do Pisma Świętego, do Chrystusa, by wewnętrznie przetwarzał wiarę jako człowiek tej epoki, w której żyje i która jest jego epoką - z której nie może przecież uciec. A gdy potrafi wyrażać wiarę poprzez swą osobistą głębię, wtedy nowe brzmienie samo się pojawia" 28 .

Taka komunikacja staje się więc zaproszeniem do osobowej komunii - najskuteczniej i najłatwiej komunikuje się treści w środowisku wspólnego doświadczenia, którego horyzontem jest cała rzeczywistość, bez żadnych ograniczeń i zastrzeżeń. Nawiązując do praktyki Kościoła starożytnego, kard. Ratzinger stwierdza, że chodzi o to, by „rzeczywiste zaproszenie do doświadczenia nie było niczym innym mówiąc naszym ludzkim językiem - jak misjonarską siłą pierwotnego Kościoła" ${ }^{29}$. To założenie sprawia, że dla Ratzingera centralną kwestią w misji Kościoła jest katecheza, która ma wybitne znaczenie kulturotwórcze. To jest właściwe miejsce udziału Kościoła w przemianie świata. Ona promuje twórcze znaczenie rozumu w wierze, a więc rozwiązuje egzystencjalnie jedno z najbardziej aktualnych dzisiaj zagadnień, będąc odpowiedzią na zamieszanie społeczno-kulturowe wywoływane przez rozpowszechniony nihilizm. Ta sama wizja relacji między wiarą, historią i kulturą stała u podstaw szerokiego zaangażowania kard. Ratzingera w debaty dotyczące rozmaitych kwestii politycznych, ekonomicznych i kulturowych.

28 Tenże, Sól ziemi, s. 224.

29 Tenże, Patrzac na Chrystusa. Ćwiczenia w wierze, nadziei, miłości, tłum. W. Kaiser, Warszawa 1991, s. 25. 
Jeśli mowa o doświadczeniu wiary i jej weryfikacji eklezjalnej, to nie sposób nie nawiązać tutaj do jeszcze jednej kwestii ważnej dla kard. Ratzingera, najpierw jako teologa, a potem jako prefekta Kongregacji Nauki Wiary, a mianowicie kwestii eklezjalnego wymiaru teologii. Kwestia ta jest tym pilniejsza, że w obecnej wizji nauki w ogóle została wyeliminowana kwestia autorytetu, będąca w znacznej części efektem wyeliminowania kwestii prawdy. Również w teologii w znacznej mierze została zakwestionowana rola autorytetu, czyli Urzędu Nauczycielskiego Kościoła. Ratzinger tak podsumowuje aktualny stan rzeczy w tej dziedzinie: „Wewnętrzna konieczność i to, co pozytywne w Urzędzie Nauczycielskim, utraciły dziś swoją oczywistość także w ogólnej świadomości teologicznej. Autorytet Kościoła ukazuje się dziś jako instancja naukowa, która w zasadzie, zgodnie z logiką nauki, nie powinna istnieć" ${ }^{30}$.

Nie wchodząc w szczegółowe zaprezentowanie sposobu ujmowania tego zagadnienia przez kard. Ratzingera, który jest bardzo rozbudowany i ma wiele zastosowań, warto zwrócić uwagę na punkt wyjścia jego propozycji. Ratzinger wychodzi więc od podstawowego znaczenia Kościoła jako nowego podmiotu, do którego zostaje wcielony każdy wierzący poprzez chrzest. Tylko żywa i czynna obecność w tym podmiocie, zapoczątkowana przez chrzest, jest źródłem poznania prawd wiary, uczestniczenia w nich oraz ich coraz głębszego rozumienia. Wynika to z samej natury wiary chrześcijańskiej, która pierwszorzędnie - jak wyraźnie pokazuje celebracja chrztu - jest „wiarą eklezjalną”, a dopiero drugorzędnie jest „wiarą indywidualną”. Pisał kard. Ratzinger: „Nie ma wiary bez Kościoła. $[\ldots]$ «Ja» wyznania wiary chrześcijańskiej nie jest wyizolowanym «ja» jednostki, ale zbiorowym «ja» Kościoła. Kiedy mówię: «ja wierzę», oznacza to, że przekraczam granice mojej podmiotowości, by zintegrować się z «ja» Kościoła, a równocześnie integruję się z jego wiedzą, przekraczając granice czasu. Akt wiary jest zawsze aktem, przez który wchodzi się w komunię z całością. Jest aktem komunii, przez który pozwalamy się zintegrować z komunią świadków,

30 Tenże, Prawda $w$ teologii, s. 52. 
a w ten sposób przez nich dotykamy tego, co niedotykalne, słyszymy to, co niesłyszalne, widzimy to, co niewidzialne. [...] Nasza wiara jest ze swej istoty aktem wypełnianym z całym Kościołem" ${ }^{31}$.

Jak chrześcijanin przez swoją osobistą wiarę uczestniczy w wierze Kościoła, tak teolog w wierze Kościoła otrzymuje zasadniczy dostęp do treści, które bada i które jawią mu się w ich pierwotnym znaczeniu. Teolog nie tworzy treści wiary, ale je odkrywa w wierze Kościoła i w tej wierze powinien dążyć do ich rozumienia. Dlatego Kościół jest właściwym miejscem i kryterium uprawiania teologii oraz ostateczną instancją jej wyników i propozycji.

Jest możliwe dojście do mądrości porządkującej całą rzeczywistość i wszelkie nasze doświadczenia, mądrości, którą jest Jezus Chrystus, jeśli idzie się drogą odważnej i konsekwentnej teologii; co więcej - można tej mądrości już teraz zakosztować, jeśli tą drogą idzie się wytrwale, patrząc na Kościół i świat. A oto ostatecznie chodzi.

31 Tenże, Przekazywanie i źródta wiary, [w:] Powstanie i znaczenie Katechizmu Kościoła Katolickiego, s. 77. 


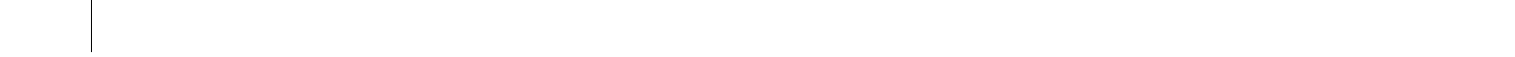




\section{ROZDZIA $\mathrm{V}$}

\section{米 \\ Teologia jako nauka poszukująca sensu, wolności i mądrości}

Spośród pojęć użytych w tytule być może tylko „poszukiwanie” może zostać uznane za współnaturalne z mentalnością naszych czasów. Na pewno wszyscy ludzie, nawet jeśli nie zawsze w sposób refleksyjny, czegoś szukają. Mogą się więc zdefiniować jako poszukujący. Pojęcie nauki, chociaż zajmuje poczesne miejsce w dzisiejszym życiu społecznym i kulturze współczesnej, mimo wszystko nie odznacza się wyraźnym uniwersalizmem, ponieważ na ogół nauka jest definiowana w ramach zawężonego ujęcia metodologicznego, wyróżniającego się stosowaniem metody matematycznej, dając niekwestionowane pierwszeństwo naukom przyrodniczym z wyraźnie widoczną szkodą dla nauk humanistycznych. Swoisty „imperializm" tej metody badawczej doprowadził do sytuacji, w której każda dyscyplina naukowa nieopierająca się wprost na matematyce jest uważana za pseudonaukową, a jeśli któraś usiłuje obronić swoją naukową pozycję, najczęściej czyni to przez włączenie matematyki do swojego postępowania metodologicznego ${ }^{1}$. Na przykład psychologia, definiowana w przeszłości jako „nauka o duszy”, w znacznym stopniu stała się nauką o tym, co wyliczalne w ludzkich

1 Por. G. Cottier, Les chemins de la raison. Questions d'epistemologie theologique et philosophique, Saint-Maur 1997, s. 223-232. 
zachowaniach. Czy jednak wolność, która stoi u podstaw ludzkich zachowań, uzasadnia taką redukcję? Czy wolność da się opisać przy pomocy matematyki? Trudno się potem dziwić, że chciałoby się bezbłędnie wyliczyć efekt osiągniętego przez naukę poznania, najczęściej odnosząc go do „postępu” ekonomicznego i jednoznacznie określonej korzyści finansowej? Nie ulega wątpliwości, że w takim kontekście teologia, pretendująca do miana nauki i szukająca dla siebie miejsca pośród innych nauk, znajduje się w trudnej sytuacji metodologicznej i budzi podejrzenia, a niejednokrotnie poddawana jest także naciskom, których celem jest pozbawienie jej właściwej dla niej specyfiki, ograniczenie jej miejsca pośród innych nauk, a zatem także jej możliwego oddziaływania. Zresztą każdy uczciwy teolog zauważa "nieprzystawalność teologii do innych nauk", dlatego w punkcie wyjścia zgadza się na uprawianie nauki spotykającej się z niezrozumieniem.

Także włączone do tytułu pojęcia sensu, wolności i mądrości, które nie mają charakteru matematycznego i nie dadzą się wyliczyć, jawią się co najwyżej jako pewne „stany ducha”, którymi zainteresowanie może być zakwalifikowane jako hobby w czasie wolnym od zajęć, ewentualnie jako przedmiot refleksji emerytów patrzących na dobiegające powoli kresu życie. Oczywiście kwestie sensu, wolności i mądrości pojawiają się w filozofii, która samookreślała się kiedyś jako „umiłowanie mądrości”, bądź też w psychologii, która dopracowała się $\mathrm{w}$ ramach swoich poszukiwań logoterapii, a więc w pewnym sensie „sensoterapii”, ale nie stanowią mimo wszystko pierwszorzędnego przedmiotu zainteresowań tych dziedzin nauki ${ }^{3}$.

Wychodząc od tych ogólnych obserwacji, musimy stwierdzić, że mówienie o teologii w takim kontekście nie jawi się jako coś prostego, łatwego ani szczególnie pociągającego. Nie oznacza to jednak, że my teologowie z nauką, którą kultywujemy, mamy łatwo wycofać się z nieprzychylnego świata albo zamknąć w getcie, w którym dzielilibyśmy swoje troski z przychylnymi jeszcze słuchaczami, którzy

2 K. Rahner, Doświadczenia katolickiego teologa, „Znak” 44 (1992) nr 2, s. 79.

3 Por. V.E. Frankl, Wola sensu. Założenia i zastosowania logoterapii, Warszawa 2010. 
nie wahają się iść pod prąd dominującej mentalności. Jako teologowie jesteśmy równocześnie pasterzami, nauczycielami, badaczami, wiernymi Kościoła, i ta wielowymiarowa tożsamość domaga się od nas otwarcia i obecności wszędzie tam, gdzie pojawiają się ludzkie pytania dotyczące Boga i człowieka ${ }^{4}$.

\section{UZASADNIENIE TEOLOGII W UJĘCIU ŚW. TOMASZA Z AKWINU}

Święty Tomasz z Akwinu był pierwszym filozofem i teologiem, który na długie stulecia nowocześnie zdefiniował naturę i metodę teologii oraz określił jej zadania w Kościele i miejsce pośród innych nauk. Jego ujęcie zostało przygotowane długą ewolucją rozumienia podstawowych pojęć chrześcijańskich, zwłaszcza pojęcia wiary, oraz poszukiwania relacji zachodzących między nią i podstawowymi rzeczywistościami ludzkimi, zwłaszcza rozumem i tym wszystkim, co on tworzy ${ }^{5}$. Sukces Akwinaty nie był więc przypadkowy, a wiele $\mathrm{z}$ jego osiągnięć stanowi trwałe i podstawowe dziedzictwo dzisiejszej teologii.

W tym miejscu zostaną przypomniane tylko ogólne założenia, na których oparł się on, opracowując monumentalne dzieło, jakim jest Summa theologiae. Sformułowane zostały one w słynnej kwestii pierwszej, z zwłaszcza w artykule pierwszym: Utrum sit necessarium praeter philosophicas disciplinas aliam doctrina haberi. Analizując więc pierwszy artykuł Sumy Tomaszowej, z łatwością zauważamy, że przyjęte przez niego założenia mają charakter dogłębnie antropologiczny, czyli, mówiąc ogólnie, wychodzą od tak zwanego konkretnego człowieka i tego człowieka mają na względzie ${ }^{6}$. Nawiązują do jego natury i jego podstawowych poszukiwań. Już z samego tego

4 Por. A. Chapelle, À lécole de la teologie, Bruxelles 2013, s. 23-33.

5 Por. U. Köpf, Die Anfange der theologischen Wissenschaftstheorie im 13. Jahrhundert, Tübingen 1974.

6 O oryginalności ujęcia Tomasza z Akwinu zob. [w:] S. Tugwell, Thomas Aquinas. Introduction, [w:] Albert and Thomas. Selected writings, ed. S. Tugwell, New York-Mahawah 1988, s. 199-351; M. D. Chenu, Święty Tomasz z Akwinu i teologia, tłum. A. Ziernicki, W. Szymona, Kraków 1997. 
powodu, że chodzi o pierwotne ludzkie poszukiwania, warto zwrócić uwagę na Tomaszową propozycję. Jak zauważyliśmy, poszukiwanie jest charakterystycznym rysem współczesnego człowieka, stawiającym go w najbardziej bezpośredniej ciągłości z człowiekiem należącym do minionych czasów i pokoleń. Rys ten wpisuje się głęboko w biblijną wizję człowieka, skoro poszukiwanie stanowi jeden z decydujących rysów starotestamentowego psalmisty, czyli człowieka modlącego się. Ważnym, niejako oficjalnym potwierdzeniem tego rysu człowieka w wizji chrześcijańskiej jest encyklika Fides et ratio papieża Jana Pawła II.

Święty Tomasz widzi zatem zasadniczo człowieka jako istotę poszukującą - mówiąc konkretniej, poszukującą prawdy o swoim celu ostatecznym i o drodze, która prowadzi do jego osiągnięcia. Do poznania tej prawdy uzdalnia go już sam rozum, a uprzywilejowaną drogą, która do tego prowadzi, jest filozofia. W czasach Akwinaty, dziedziczących przekonania wieków wcześniejszych, była ona uważana za najwyższą naukę, do uprawiania której zdolny jest człowiek posługujący się swoimi naturalnymi siłami poznawczymi. W afirmowaniu filozofii przez św. Tomasza widzimy otwartą afirmację naturalnych zdolności poznawczych człowieka, które stanowią odzwierciedlenie i wyrażenie go jako istoty rozumnej. Tym stwierdzeniem św. Tomasz potwierdza także pozytywne nastawienie chrześcijaństwa do całego porządku naturalnego, w którym zanurzony jest byt człowieka. Pozytywne uznanie tego porządku nie oznacza jednak równoczesnego uznania samowystarczalności bytowej oraz samowystarczalności poznawczej człowieka. Ten brak dotyka więc człowieka i ogranicza jego samorealizację. Wyjątkowo dotkliwe dla człowieka jest ograniczenie w odniesieniu do jego zdolności rozumowego poznania celu, do którego się kieruje i ma kierować, a którym jest Bóg. Ponieważ Bóg nieskończenie przekracza porządek naturalny, a więc człowieka i jego zdolności poznawcze, dlatego - aby człowiekowi pomóc w koniecznym dla niego poznaniu celu oraz drogi prowadzącej do niego - potrzebna jest „inna nauka”, to znaczy nauka „od Boga natchniona”, „pochodząca z objawienia Bożego". Oczywiście ta nauka nie zmierza tylko do uzupełnienia ludzkiego poznania, ale ma sens mocno egzystencjalny, 
którym jest zbawienie, czyli rzeczywiste osiągnięcie przez człowieka poszukiwanej pełni istnienia. Odnosi się do realnego spełnienia się człowieka w poznawanym celu. Teologia ma więc za zadanie pokazać człowiekowi, jak swoje pobudki i czyny zwracać do właściwego dla niego celu, ponieważ rzeczywiście może osiągnąć zbawienie, spełniając się w czynie. Można powiedzieć, że teologia, na miarę swoich możliwości, ma wpływać na kształt woli człowieka, która w osiągnięciu zbawienia odgrywa decydującą rolę. Teologia służy więc zaspokojeniu ludzkiego zwracania się do Boga, na które Bóg uprzednio i łaskawie odpowiada swoim objawieniem, czyli mówi o sobie i działa na rzecz człowieka ${ }^{7}$.

W swoim uzasadnieniu teologii św. Tomasz uwypukla jeszcze drugi problem, również o charakterze antropologicznym. W pierwszym przypadku, afirmując zdolności poznawcze człowieka niejako w sensie ogólnym, uwzględnił on fakt, że w ogóle te zdolności są ograniczone. Mamy więc tutaj odpowiedź na pewną charakterystykę ontologiczną dotyczącą człowieka w ogólności. Postawienie sprawy przez Akwinatę ma dalszy ciąg: zamierza on równocześnie wyeliminować coś w rodzaju ekskluzywizmu poznawczego. Jest on mianowicie świadomy, że poznanie Boga jest sprawą zasadniczą dla każdego człowieka, zarówno zdolnego, jak i mniej zdolnego pod względem urzeczywistniania tej wewnętrznej potrzeby. Przyjmuje on jako fakt, że zdolności człowieka nie tylko są ograniczone, ale ta ograniczoność jest również bardzo zróżnicowana. Aby wyeliminować uprzywilejowanie zdolniejszych w dziedzinie poznania Boga poznania o podstawowym znaczeniu dla każdego człowieka, skoro wszyscy pragną osiągnięcia zbawienia - św. Tomasz w objawieniu Bożym, które jest podstawą teologii, widzi możliwość zbawienia otwartą dla każdego człowieka. Stwierdza więc, że bez objawienia „prawdę o Bogu, tak jak ją ujmuje rozum, osiągnęliby nieliczni po długim czasie i z przymieszką wielu błędów". Większa dostępność i pewność wiedzy o Bogu, której potrzebuje człowiek

7 Benedykt XVI - J. Ratzinger, Formalne zasady chrześcijaństwa. Szkice do teologii fundamentalnej, tłum. W. Szymona, Poznań 2009, s. 425-435.

8 Tomasz z Akwinu, Summa theologiae I q. 1 a. 1. 
do osiągnięcia zbawienia, stanowi więc podstawę objawiającego działania Bożego.

Teologia jako „nauka święta”, wyrastająca z objawienia Bożego, jest nauką o Bogu, ale jej geneza i cel mają w najwyższym stopniu charakter antropocentryczny. Bierze ona przede wszystkim pod uwagę sytuację egzystencjalną człowieka w jej całokształcie - sytuację ontologiczną, psychologiczną, kulturową itd. - oraz jego uwarunkowania i zdolności intelektualne, zmierzając do tego, aby człowiek poznał Boga jako swój cel i odnalazł drogę do Niego. Potrzeba teologii jest podyktowana wewnętrzną sytuacją duchową człowieka, której najmocniejszym wyróżnikiem jest jego pragnienie zbawienia - tę sytuację i możliwość jej podjęcia w decydującym stopniu określa ludzka racjonalność.

Trzeba w tym miejscu oczywiście przypomnieć, że z punktu widzenia duchowego i eklezjalnego teologia nie jest najwyższą służbą na rzecz zbawienia człowieka. Służbę o takiej nośności spełnia przepowiadanie słowa Bożego, a więc kazanie. Przepowiadanie stanowi najwyższy rodzaj posługi na rzecz zbawienia człowieka, ze względu na to, że ma wewnętrzne uzdolnienie i nastawienie na prowadzenie do osiągnięcia tego celu. Teologia tego wprost nie czyni jej zadanie jest skromniejsze, polegające na przygotowaniu zdolności poznawczych wierzącego do przyjęcia orędzia zbawczego oraz pogotowaniu kaznodziei do jak najlepszego przekazywania treści objawionych, dostosowanych do poznania posiadanego przez człowieka i do zróżnicowanych zdolności w tej dziedzinie9.

Uzasadnienie Akwinaty zachowuje do dzisiaj wartość merytoryczną, opierając się na podstawowych i raczej niekwestionowanych założeniach i celach; co więcej, w dzisiejszym klimacie „zwrotu antropologicznego" jawi się nawet jako nowatorskie. Jakkolwiek uzasadnienie dane przez Akwinatę może być nieco nieczytelne, zwłaszcza w odniesieniu do kwestii celu, gdyż to pojęcie nie spełnia dzisiaj już tak zasadniczej funkcji filozoficznej i kulturowej jak w minionych epokach, gdy mowa o człowieku. Podobnie ma się

9 Por. J. P. Torrell, Thomas d'Aquin prédicateur, „Revue Thomiste” 82 (1982), s. $213-245$. 
rzecz, przynajmniej na pierwszy rzut oka, z kwestią zbawienia, które nie jawi się już jako naczelne pragnienie człowieka. Oczywiście jest to kwestia nadal ważna, ale sytuuje się pośród wielu innych ludzkich pragnień i poszukiwań. Z tego powodu w spojrzenie na człowieka wdarły się rozmaite zawirowania, wywoływane na przykład mitem samowystarczalności człowieka czy też przekonaniem o jakoby nieograniczonych zdolnościach poznawczych człowieka. Dlatego też spojrzenie na Boga i Jego objawienie, a więc i na teologię, i jej znaczenie w życiu wierzącego, poddawane jest redukcyjnym interpretacjom.

Mimo tej problematyczności uzasadnienie teologii jako nauki zaproponowane przez św. Tomasza z Akwinu zawiera elementy, które mogą być traktowane jako aktualne i inspirujące. Szczególnie aktualny i inspirujący może być antropologiczny punkt wyjścia w uzasadnianiu jej potrzeby. Wskazuje on na zasadność pytania, czy „nowy” - pod bardzo wieloma względami - człowiek odkrywa w sobie jakąś potrzebę, która domagałaby się interpretacji teologicznej, czyli opartej na Bogu. Jeśli zaś taka potrzeba się ujawnia, to pojawia się druga kwestia, bardzo zasadnicza dla Akwinaty, w jaki sposób na tę potrzebę dopowiedzieć, to znaczy jak ukazać Boga objawiającego się, by cieszyła się Nim nie tylko "garstka ludzi”, ale wszyscy. Można więc powiedzieć, że chodzi w tym przypadku o wypracowanie odpowiedniego języka w mówieniu o Bogu, aby czynić powszechnie dostępną treść teologiczną.

\section{OTWARTOŚĆ LUDZKICH POSZUKIWAŃ NA TEOLOGIĘ}

Spróbujmy więc zidentyfikować miejsca, w których uwidacznia się otwartość człowieka na Boga, a więc i na problem teologii. Jak zauważyliśmy na początku, pewnym znakiem rozpoznawczym dzisiejszego człowieka jest poszukiwanie. Człowiek poszukuje oczywiście wielu rzeczy, czyli przedmiot jego poszukiwań pozostaje nadzwyczaj urozmaicony. Niemniej jednak, wchodząc w głąb dzisiejszej kultury, a więc ogólnej sytuacji duchowej życia ludzkiego, da się zidentyfikować niektóre przedmioty tego poszukiwania, 
których poznanie wykracza poza dziedzinę nauk przyrodniczych, a ich określenia nie da się dokonać za pomocą nawet najbardziej wyszukanych narzędzi matematycznych. Dotarcie do tych przedmiotów i zajęcie się nimi wymaga głębszego namysłu egzystencjalnego i uwzględnienia bogatego dziedzictwa zgromadzonego w skarbnicy ludzkich doświadczeń - nie eksperymentów! - duchowych. Wydaje się więc, że szczególnie ważne może być zwrócenie uwagi na trzy sfery ludzkich poszukiwań, które zostały wskazane w tytule, to znaczy poszukiwanie sensu, poszukiwanie mądrości i poszukiwanie wolności (miłości).

\subsection{POSZUKIWANIE SENSU}

Wśród wielu pytań, które zadają ludzie wszystkich czasów, choć rozmaicie je formułują (jest ono na pewno przynajmniej pośrednio zawarte w postawionej przez św. Tomasza kwestii celu), jednym z częstszych i bardziej naglących jest na pewno pytanie o sens. Pojawia się ono zwłaszcza tam, gdzie człowiek w sposób bezpośredni spotyka się ze złem, i to zarówno fizycznym, jak i moralnym, a więc - mówiąc konkretniej - z cierpieniem i śmiercią jako najwyższym przejawem zła fizycznego oraz z grzechem jako najwyższym przejawem zła moralnego. Papież Jan Paweł II w encyklice Fides et ratio trafnie zauważył, że „wszystko to wystarcza, aby zmusić nas do dramatycznego pytania o sens" (nr 26). Warto zwrócić uwagę na to, iż papież nie waha się mówić o dramatyczności tej kwestii. Jest tak dlatego, że zło rzeczywiście wywołuje w człowieku najgłębiej wnikający i najbardziej niepokojący stan duchowy, który od wieków wstrząsa każdym i całym człowiekiem. Pytanie „Unde malum?” kładzie się mrocznym i niepokojącym cieniem na ludzkim losie.

Wobec dramatyczności swojej egzystencji człowiek podejmuje więc poszukiwanie odpowiedzi wyjaśniającej, mającej dać mu powód do życia, dokonywania wyborów, poświęcania się, dążenia do czegoś itd., a w końcu poddającego się przyjęcia cierpienia i śmierci z nadzieją, że nie są one ostatnim słowem wypowiadanym nad ludzkimi dziejami. Nawet jeśli ktoś twierdzi, że wszystko jest absurdem, a jedyną odpowiedzią na to, co spotyka człowieka 
jest „samobójstwo”, jak chciał Albert Camus, to i tak jest to świadectwo niepokojącego poszukiwania rozumienia siebie i historii, czyli poszukiwania sensu ${ }^{10}$.

O co więc chodzi w poszukiwaniu sensu? Najpierw chodzi ogólnie o znalezienie pewnego i godnego afirmacji kierunku, do którego można by się zwrócić, wychodząc z przekonania, że taki kierunek otworzy możliwość odpowiedniego, na miarę bycia człowiekiem, pokierowania swoim życiem. Po drugie, w sensie bardziej bezpośrednim, sens jest spokrewniony z prawdą, przede wszystkim prawdą rzeczywistości, prawdą bytu, prawdą egzystencji. Sens wskazuje w tym przypadku na to, co zrozumiałe, co daje wyjaśnienie, co jednoczy wielość rzeczy i wielość ludzkich doświadczeń, co uzasadnia wysiłek dokonywania odważnych i trudnych wyborów, co pozwala nadać pewność i jakąś stałość temu, co nieuchronnie przemija. Tak rozumiany sens wyłania się jako coś pierwotnego, co nie zależy od ludzkiej świadomości i ludzkiego rozumowania; skłania do sięgania do tego, co coraz bardziej podstawowe, co jest rzeczywistością ontologiczną, jak powiedziałaby filozofia klasyczna. W tym aspekcie sens różni się od znaczenia, jakie mają rzeczy i ludzkie działania, gdyż znaczenie na ogół zależy od wielu czynników, takich jak kultura, tradycja historyczna, sytuacja duchowa czasów itd. Odkrycie sensu czegoś domaga się ukazania głębszej prawdy, która jednak wymyka się temu, co można przeżyć i zobaczyć. Tymczasem jeśli chodzi o tę prawdę w jej ostatecznym fundamencie, a więc i o sens ostateczny, to trzeba stwierdzić, że wciąż na nowo wymyka się on człowiekowi, przekraczając wszelkie interpretacje, które wypracowuje i proponuje człowiek. Sama niejako natura sensu, zakorzeniając się w absolutnej głębi człowieka, jawi się jako powołanie do wzrastania w byciu czymś więcej, co ostatecznie jest nieosiągalne samo z siebie, a więc może być tylko da n e może być tylko objawione i musi być takie. Staje się to szczególnie ewidentne, gdy zestawimy to wszystko, co zostało powiedziane, z kwestią śmierci i grzechu.

10 Por. Th. De Koninck, Dire Dieu aujourd'hui, „Laval Théologique et Philosophique" 58 (2002), s. 503-530. 
W kolejnym aspekcie sens jawi się jako spokrewniony z wartością - z tym, co dobre. Tym, co określa sens ludzkiego bytu w jego działaniu, okazuje się dobro - jako to, co powszechnie i najwyżej upragnione, a co człowiek chce odzwierciedlić w swoim działaniu, dążąc do zapewnienia sobie trwania przekraczającego wąskie ramy ziemskiej egzystencji.

Dla chrześcijan jedyne pozytywne, logiczne i historycznie sprawdzone rozwiązanie problemu sensu ukazuje się w zmartwychwstaniu Jezusa Chrystusa, które jest zwycięstwem nad grzechem i śmiercią. Wiara chrześcijańska opiera się na tym jedynym, historycznym i cudownym wydarzeniu, widząc w nim najwyższą odpowiedź na pytanie o śmierć i grzech, która może okazać się zadowalająca dla człowieka, dostarczając mu racji życia i działania opartego na wybieraniu dobra, w którym dokonywałby przekroczenia siebie. Ludzkie pytanie o sens jest więc także pytaniem o Boga, który oferuje człowiekowi swoją odpowiedź, proponując mu oparcie na niej swego życia.

\subsection{POSZUKIWANIE WOLNOŚCI}

Do podstawowych poszukiwań, które głęboko fascynują, a zarazem głęboko niepokoją człowieka, należy poszukiwanie wolności. Z jednej więc strony rodzi się w każdym człowieku pragnienie dokonywania wyborów i podejmowania decyzji. Człowiek dzisiejszy dojrzał do przekonania, że w tej zakorzenionej w nim zdolności widzi najwyższy wyraz siebie. Możliwość dokonywania dobrowolnych wyborów utożsamiona jest $\mathrm{z}$ możliwością wyrażenia się człowieka jako człowieka, czyli „bycia sobą” - jak zwykło się dzisiaj mówić, choć jest to stwierdzenie dwuznaczne. Jest to zresztą przekonanie ściśle odpowiadające samej istocie chrześcijaństwa, które weszło w świat starożytny z rewolucyjnym orędziem powszechnej wolności. Zawdzięczamy go konkretnie św. Pawłowi, który w Liście do Galatów, interpretując skutki zbawczego dzieła Jezusa Chrystusa, stwierdza: „Ku wolności wyzwolił was Chrystus” $($ Ga 5,1$)$ - wyzwolił wszystkich: „Nie ma już Żyda ani poganina, nie ma już niewolnika ani człowieka wolnego, nie ma już mężczyzny 
ani kobiety, wszyscy bowiem jesteście kimś jednym w Chrystusie Jezusie" $\left(\mathrm{Ga} \mathrm{3,} \mathrm{28)}{ }^{11}\right.$.

Z drugiej jednak strony człowiek szukający wolności z łatwością zauważa, że urzeczywistnienie wolności, o której fundamentalnym znaczeniu jest przekonany, nie jest bynajmniej proste. Ograniczenie wolności powodowane jest obecnością drugiego człowieka i świata, a przede wszystkim niezdolnością do dokonywania wyborów „nieomylnych", to znaczy takich, które zawsze służyłyby człowiekowi, jego szczęściu i rozwojowi, a także wyrażały wspólnotę z innymi. Ludzkie czyny, mające być miarą i wyrazem wolności człowieka, są zarażone błędami, które sumienie demaskuje jako zło, dotkliwie kwestionujące samego człowieka i porządek, który go otacza. Człowiek nieustannie przegrywa „próbę wolności”, a tradycja religijna nazywa tę porażkę grzechem, stale akcentując jego dramat i jego destrukcyjne skutki.

Z poszukiwaniem wolności ściśle łączy się następnie poszukiwanie miłości, która już w najbardziej potocznym doświadczeniu ukazuje swoje ścisłe związki z wolnością, jawiąc się jako jej najwyższe ukierunkowanie. Człowiek pragnie kochać, a kochając, mówić: „Kocham, więc jestem”, jak trafnie wyraził tę potrzebę Wiaczesław Iwanow. Zarazem jednak ugina się pod ciężarem tego wyzwania, widząc jego rozmaite ograniczenia w dokonywanych wyborach, które nie dorastają do miary pragnienia, i ostateczne niespełnienie w ramach chęci i możliwości, którymi dysponuje. Rozmaite teorie miłości, które filozoficznie zbudowano i które potem próbowano nawet najbardziej rygorystycznie wprowadzać w życie, nie wytrzymały próby czasu i nie przeszły pozytywnie weryfikacji historycznej.

Czy jednak te pragnienia związane $\mathrm{z}$ osiągnięciem wolności miałyby być tylko mirażem, przejawem chorej wyobraźni, fantazją oderwaną od zwyczajnego życia? Czy wolność jest skazana na niespełnienie z powodu zła? Czy jest wirem wciągającym w pustkę i przebudzeniem szalonej fantazji, która rozmywa się w mgle bez przyszłości? Czy miłość, jawiąca się jako wzniosła i szlachetna

11 Por. S. Lyonnet, La carità pienezza della legge secondo san Paolo, Roma 1971, s. 79-96. 
rzeczywistość prowadząca do spełnienia ludzkiej osobowości, byłaby tylko ułudą, skazującą człowieka na zagubienie się w wirze coraz to nowych neuroz?

Wolność, jakkolwiek byśmy ją pojmowali i interpretowali, woła o wsparcie z zewnątrz, domaga się oczyszczenia, szuka oświecenia i pewności. Uczciwa refleksja filozoficzna, kierując się zasadą samego rozumu, już niejednokrotnie wykazała, że autentyczna wolność domaga się istnienia osobowego Absolutu ${ }^{12}$. Bez Boga powszechna wolność jest niemożliwa do przyjęcia i wprowadzenia w życie. $\mathrm{Na}$ to poszukiwanie filozoficzne nakłada się perspektywa chrześcijańska, proponująca trudną, ale realistyczną odpowiedź na ludzkie poszukiwanie wolności. Bóg i Jego zwycięska łaska przynoszą odpuszczenie grzechów, dokonując oczyszczenia ludzkiej wolności, uwalniając ją od ciężaru przegranych decyzji oraz uzdalniając ją do podejmowania decyzji w imię dobra, które wypełniają się w miłości. Oferując człowiekowi odpuszczenie grzechu i uwolnienie od winy, Bóg wprowadza człowieka na drogę miłości, jedyną, która może usatysfakcjonować człowieka w jego najwznioślejszych poszukiwaniach. Święty Paweł w Liście do Rzymian stwierdza z zachwytem, który może udzielić się człowiekowi wchodzącemu na tę drogę: „Miłość Boża została rozlana w sercach naszych przez Ducha Świętego, który został nam dany" $(5,5)$.

\subsection{POSZUKIWANIE MĄDROŚCI}

Doświadczenie, które wyraźnie i boleśnie niepokoi dzisiaj wielu ludzi, związane jest z nasilającym się w świecie i we wnętrzu człowieka chaosem. Dotyka on zarówno sfery osobistej człowieka, jak i całego „kosmosu”, w którym jest zanurzony, jak również sfery relacji społecznych i kulturowych, które stanowią jego właściwe środowisko życiowe. Postęp naukowy i techniczny nie rozwiązuje tego problemu; wręcz przeciwnie, pogłębia jeszcze bardziej dający

12 Por. C. Fabro, Riflessioni sulla libertà, Rimini 1983, s. 13-55; J. Królikowski, Zrehabilitować cnotę. Poszukiwania teologicznomoralne, Tarnów 2004, s. $17-44$. 
się odczuć chaos. Relacje społeczne i kulturowe nie poddają się łatwemu uporządkowaniu, mimo iż opracowuje się coraz to nowe „projekty”, które mają do tego przybliżać, i promulguje się coraz to nowe „prawa”, które stawiają sobie szczytne cele wprowadzenia porządku w relacje międzyludzkie. A człowiek i społeczeństwo i tak ulegają coraz większemu rozbiciu, jak z niepokojem zauważył już Fryderyk Nietzsche. W naszych czasach to rozbicie zaszło tak daleko, że zostało już podniesione do rangi kategorii definiującej współczesny świat. Bardzo wymownie zastosował tę kategorię do interpretacji współczesnego świata Aleksander Sołżenicyn w słynnej mowie wygłoszonej na Harvardzie 8 czerwca 1978 roku z okazji nadania mu doktoratu honoris causa.

Konsekwencją świata rozbitego, jak już słusznie zauważono, jest odradzanie się w mentalności współczesnej mitu Narcyza. Jego najbardziej wyrazistym przejawem jest redukowanie wszelkich zainteresowań i dążeń człowieka do samego siebie, a więc skrajny egoizm i pycha, przejawiające się w pokazywaniu swojej siły. Filozoficznie można by mówić o powrocie do tradycji presokratejskiej, który sprawia, że na nowo cnotę utożsamia się z siłą. Konsekwencją tego stanu rzeczy może być tylko dalsze rozbicie człowieka i społeczeństwa.

W takim kontekście staje się zrozumiałe, że człowiek podejmuje poszukiwania, które zmierzają do przywrócenia porządku w człowieku i w świecie, odwołując się do sprawdzonego środka, jakim jest mądrość. Dowodzi tego ciesząca się na całym świecie coraz większym zainteresowaniem literatura mądrościowa, która autentycznie rehabilituje mądrość jako naczelną zasadę życia i działania ludzkiego oraz fundament relacji społeczno-kulturowych. W klasycznym rozumieniu mądrość jest po prostu „porządkowaniem” wielości rzeczy i doświadczeń w oparciu o jak najwyższe pryncypium, przyczynę czy zasadę ${ }^{13}$.

W tym kontekście także otwiera się perspektywa teologiczna, która w ludzkie poszukiwania wnosi propozycję porządkowania wszelkiej rzeczywistości w świetle najwyższej zasady, którą jest

13 Por. C. Fabro, La teologia come scienza e come sapienza in san Tommaso, „Annales Theologici” 1 (1987), s. 95-105. 
Bóg ${ }^{14}$. Teologia jest mądrością. Święty Tomasz z Akwinu mówi nawet: „Spośród wszystkich mądrości ludzkich [teologia] w najwyższym stopniu jest mądrością, i to nie tylko pod pewnym względem, ale zasadniczo"15. Wyjaśnia to stwierdzenie w taki sposób: „Wiedza święta [teologia] orzeka najwłaściwiej o Bogu jako o najwyższej przyczynie, ponieważ orzeka o Nim nie tylko to, co jest poznawalne przez stworzenia - to poznali filozofowie - jak czytamy w Liście do Rzymian $(1,19)$ : «co można o Bogu poznać, jest im jawne», lecz także to, co znane jest Jemu samemu o Nim samym, a innym zostało przekazane przez objawienie. Mówi się zatem, że wiedza święta jest w najwyższym stopniu mądrością"16. Teologia może więc wnieść swój wkład do dzisiejszych poszukiwań i w tej perspektywie może być widziana we współczesnym kontekście antropologicznym i kulturowym.

\section{DOPEŁNIENIE METODYCZNE LUDZKICH POSZUKIWAŃ}

Przez proroka Izajasza Bóg kieruje do ludzi wymowne wezwanie: „Szukajcie Pana, gdy się pozwala znaleźć, wzywajcie Go, dopóki jest blisko" $(55,6)$. Człowiek nosi w sobie pragnienie Boga, pragnienie wypisane głęboko i wyraźnie w swoich własnych doświadczeniach i niepokojach. Pragnienie Boga nakłada się na ludzkie pragnienia, nakłada się tak bardzo, że stają się one wręcz współnaturalne. Pozwala to uznać, na co zwrócił już uwagę św. Augustyn, że Bóg jest rzeczywiście „blisko” i rzeczywiście „pozwala się znaleźć”. Trzeba tylko uważniej spojrzeć w siebie, w swoje odczucia, doznania, poszukiwania, niepokoje itd.

Teologia, od Boga natchniona i zaangażowana po ludzku, wychodzi metodycznie naprzeciw człowiekowi poszukującemu i zadającemu pytania, starając się te poszukiwania podjąć i zinterpretować

14 Wiele trafnych uwag o wymiarze mądrościowym teologii zob. w: J. Bolewski, Inicjacja Mądrości. Dla życia, duchowości, teologii, Poznań 2012.

15 Tomasz z Akwinu, Summa theologiae I q. 1 a. 6.

16 Tamże. 
jak najgłębiej oraz na nie naukowo odpowiedzieći ${ }^{17}$. Jest to możliwe i konieczne, ponieważ powaga człowieka i powaga jego poszukiwań domaga się, by była nauką, która będzie poważnie pod względem racjonalnym, czyli na miarę jego istoty i jego wymogów, traktować człowieka i wspierać go w poszukiwaniu sensu, wolności, mądrości, a więc ostatecznie także zbawienia.

17 Por. J. P. Jossua, Peut-on parler de Dieu?, Genéve 2006. 


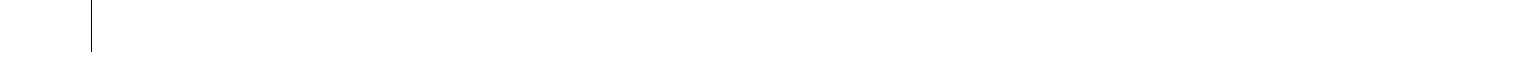




\section{ROZDZIAŁ VI}

\section{来 \\ Teologia wobec wymogu pastoralności}

\section{TEOLOGIA MIĘDZY NAUKOWOŚCIĄ I PASTORALNOŚCIĄ}

Pod adresem współczesnej teologii stawia się bardzo wiele, niekiedy nawet sprzecznych ze sobą, postulatów. Mówiąc tutaj o teologii, mam przede wszystkim na myśli te ologię sys te matyc zną, czyli teologię dogmatyczną, moralną i duchowości, która jest ośrodkiem całej teologii. Wydaje się, że większość z tych postulatów można by usystematyzować według dwóch biegunów, którymi są na u ko wość i pastoralność. Z jednej więc strony postuluje się, by teologia była staranna, systematyczna i uporządkowana pod względem nau kow ości. Chodzi w tym przypadku o jasne określenie jej natury i metody, które konstytuują każdą dziedzinę badawczą jako naukę, a potem konsekwentne kierowanie się wypracowaną metodą. Postulat uzupełniający dotyczy takiego naukowego uprawiania teologii, które pozwoli określić jej miejsce w stosunku do innych nauk. Jest to postulat, który stawia się zarówno wśród uprawiających teologię, czyli niejako „od wewnątrz", jak również jest to postulat rodzący się kręgach uczonych reprezentujących inne dziedziny nauki, czyli "z zewnątrz". Bardzo często jest to dyktowane potrzebą wzajemnego zrozumienia bądź nawiązania dialogu interdyscyplinarnego. 
To zaskakujące, ale w trakcie polskiej debaty nad włączeniem wydziałów teologii do struktur uniwersyteckich uzasadnienie najmocniejsze, czyli oparte na statusie naukowym teologii i jej uprawnionym metodycznie miejscu pośród innych nauk, nie zostało praktycznie zastosowane i wykorzystane. Odwoływano się najczęściej do tezy, że tak było w średniowieczu. Warto jednak zauważyć, że wydziały teologii na uniwersytetach średniowiecznych i późniejszych miały dobrze uzasadnioną pozycję naukową, opartą na solidnych założeniach metodologicznych, oraz wyraźnie określoną relację do innych wydziałów. Gdyby tego nie miały, to by ich tam nie było - astrologia też była na uniwersytetach, ale została usunięta, bo nie spełniała kryteriów metodologicznych, czyli nie broniła się jako nauka. O usunięciu teologii z uniwersytetów zdecydowały nie tylko kryteria oświeceniowe i wrogość wobec Kościoła, ale także kryzys teologii jako nauki. Dzisiaj wydziały teologii istniejące na wielu uniwersytetach na świecie często są marginalizowane właśnie z powodu wątłej bazy metodologicznej i działań prowadzonych w oparciu o wątpliwą naukowość. W większości przypadków winę za to ponoszą sami teologowie, którzy po prostu boją się refleksji nad naturą i metodą teologii. Kiedyś prawie każdy teolog był autorem jakiejś pracy na ten temat. W ramach „odnowionych" programów studiów teologicznych, także w Zasadach formacji kapłańskiej w Polsce, kwestia natury i metody w teologii została poważnie zepchnięta na margines. Problem urasta do tej miary, że nawet wprawni teologowie nie rozróżniają między metodą i metodologią.

$Z$ drugiej strony jako drugi biegun oczekiwań pod adresem teologii, formułuje się postulat jej większej pa st or a ln ości. Postulat ten pojawia się niemal powszechnie $\mathrm{w}$ kręgach związanych $\mathrm{z}$ formacją kapłańską. Jest to zrozumiałe, ponieważ studia teologiczne mają przygotować do pełnienia posługi duszpasterskiej. W kręgach świeckich studentów teologii mówi się raczej o „praktyczności” teologii, chociaż w gruncie rzeczy chodzi o to samo. Właściwie takim pomostem powinna być teologia pastoralna, ale ma ona ciągle problemy ze swoją tożsamością, jak i z określeniem treści, które chciałaby i powinna przekazać. Ciągle zdaje się ciążyć na niej syndrom jej genezy - przecież na początku była to „teologia państwowa”, 
która miała służyć zdyscyplinowaniu duchowieństwa w ramach destrukcyjnego józefinizmu. Nie ma więc naturalnie wykształconych korzeni teologicznych, które byłyby nośnikiem jej autentyczności. Kwestia, oczywiście, nie jest nowa, ponieważ już w średniowieczu dyskutowano, czy teologię należy uznać za scientia teoretica, czy scientia practica.

W postulacie pastoralności nie chodzi oczywiście o to, by cała teologię sprowadzić do teologii pastoralnej, którą w seminariach duchownych najczęściej rozumie się jako przygotowanie do pełnienia posługi kapłańskiej w parafii. W innych instytucjach naukowych, w których wykłada się teologię pastoralną, chodzi w niej najczęściej o jakiś rodzaj „eklezjologii egzystencjalnej”. Nawet jeśli pastoraliści nie zgadzają się na takie definiowanie ich dyscypliny, to jednak takie jej ujmowanie jest po prostu faktem. W postulacie pastoralności nie może również chodzić o tak zwaną „praktyczność”, widzianą w perspektywie pragmatyzmu, to znaczy o bezpośrednie zastosowanie czy też tak zwane „życiowe” ujęcie treści wiary i teologii. Już Arystoteles powiedział, że prawda jest praktyczna, dlatego że jest prawdą - prawda nie musi mieć praktycznego zastosowania, czyli czegoś w rodzaju „przelicznika praktycznego”. Teologia nie stałaby się bardziej pastoralna, gdyby zrezygnowała ze swojego języka czy gdyby go uprościła, jak postulują niektórzy. Tym bardziej pastoralność teologii nie wyraża się w tym, że teolog będzie pisał kazania, opracowywał materiały duszpasterskie i pomoce katechetyczne. O co więc chodzi w postulacie pastoralności? Nie ma jeszcze na to pytanie ani jednoznacznej, ani choćby ogólnie zarysowanej odpowiedzi. Tak zwana pastoralność jest często tylko pustym sloganem. Dlatego jest tym sensowniejsze, abyśmy spróbowali odpowiedzieć na to pytanie, nawet jeśli byłyby to tylko idee poddane wolnej dyskusji.

Aby poszukiwanie odpowiedzi na postulat pastoralności teologii było możliwie, sprecyzujmy w tym miejscu, co rozumiemy w ogóle przez pastoralność. Potem będziemy mogli w tym świetle patrzeć na to, czym jest i jaka powinna być teologia wrażliwa pastoralnie. Wyjdźmy więc od koncepcji wiary, czyli rzeczywistości najbardziej podstawowej dla refleksji metodologicznych o naturze i metodzie teologii. Jak rozumie się wiarę, tak również rozumie się teologię. 
Wiara, w swoim wymiarze zarówno indywidualnym, jak i wspólnotowym, jest rzeczywistością teologalną, która wyraża się (czy, mówiąc ściślej, powinna wyrazić się) a) w sposób u p or z ą d kow any, ponieważ nie jest jakimś impulsem, spontanicznością, pojedynczym aktem, ale postawą całościową, można by powiedzieć „opcją”, b) w sposób egzysten cjalny (hi s tor y cz ny), ponieważ jest rzeczywistością dotyczącą osoby i jej zaangażowania w dziejach świata, a wreszcie - c) w sposób nastawiony na osiągnięcie przez człowieka celu życia, którym jest wieczne zbawienie, który to cel ma być realizowany i antycypowany już tu i teraz. Osobowa aktualizacja tych trzech charakterystycznych elementów wiary sprawia, że wiara rzeczywiście jest tym, czym jest i ze względu na co jest. Można powiedzieć, że w tych trzech cechach wyraża się wymiar pr zedmi o to w y wiary, który określa również pastoralność pod względem przedmiotowym. Jeśli więc teologia, jako scientia fidei et salutis, ma być wrażliwa pastoralnie, to musi uwzględniać te cechy charakterystyczne wiary, czyli jej uporządkowanie (ordo, w sensie klasycznym; dzisiaj można by raczej mówić o „strukturze wiary”), jej egzystencjalność oraz jej własną celowość, aby przez to uwzględnienie wskazywać drogi do jej aktualizacji. Już sama intuicja podpowiada, że te znamiona wiary nadają jej w najwyższym stopniu charakter egzystencjalny. Jeśli więc teologia je uwzględni, z całą pewnością będzie miała wymiar pastoralny, to znaczy będzie realnie wpływać na aktualizowanie wiary. W pastoralności dobrze pojętej chodzi bowiem o to, by prowadzić wierzącego, jako jednostkę i jako wspólnotę, do uporządkowanego, egzystencjalnego i celowego aktualizowania wiary, czyli tego, by była ona tym, czym jest i ze względu na co jest.

Powiedzieliśmy dotychczas o przedmiotowym aspekcie wiary i wynikającej z tego wrażliwości pastoralnej. Ten aspekt domaga się uzupełnienia o aspekt formalny, czyli - najogólniej mówiąc o perspektywę, w której aspekt przedmiotowy będzie rozpatrywany. Tym, co określa wymiar formalny wiary, są „uwarunkowania” decydujące o jej urzeczywistnieniu, które wynikają z sytuacji, w których znajduje się wierzący, a które weryfikują się w biegu czasów. Syntetycznie ten wymiar wiary uchwycił św. Tomasz z Akwinu, stwierdzając: „Explicatio accidit nec mutat essentiam fidei, sic et 
variatio temporis determinat, non variat fidei - Wyjaśnienie nie osłabia ani nie modyfikuje istoty wiary, tak i zmiana czasów determinuje wiarę, a nie zmienia" ${ }^{18}$. W aspekcie formalnym wiary chodzi więc o uwzględnienie wpływu wywieranego na wiarę przez czynniki historyczno-kulturowe; do pewnego stopnia można mówić o jej „uwarunkowaniu czasoprzestrzennym”. Pastoralność rozpatrywana pod względem formalnym wskazuje zatem na potrzebę takiego uwzględniania czynników kulturowo-historycznych, w których żyje wierzący i Kościół oraz w których urzeczywistnia się wiara, by rzeczywiście wyrażała się ona w swojej autentyczności i mogła osiągnąć swój cel. Można powiedzieć, na przykład, że kwestia zbawienia, pozostając wciąż kwestią aktualną i pilną, domaga się takiego ujęcia, które odpowiadałoby współczesnej ludzkiej wrażliwości i aktualnym uwarunkowaniom; dzisiaj niewiele mówi już ludziom zbawienie rozumiane w perspektywie średniowiecznej.

Spróbujmy więc spojrzeć na teologię przez pryzmat tak rozumianej pastoralności oraz pokazać możliwości jej realizacji w nauczaniu i studiowaniu teologii. Zwróćmy więc uwagę na trzy kwestie: przedmiot teologii, jej treści oraz jakości duchowe w jej wykładzie. Chodzi o kwestie, które mogłyby stworzyć ogólne ramy dla pogłębienia wrażliwości pastoralnej teologii.

\section{PRZEDMIOT TEOLOGII}

Przyzwyczailiśmy się mówić bardzo pospiesznie i ogólnikowo, że przedmiotem teologii jest Bóg, i nazywać teologię po prostu nauką o Bogu. Jest to oczywiście prawdą i nie zamierzam tego kwestionować. Jednak w dzisiejszym świecie nie wystarczą już takie proste stwierdzenia. Chociaż słowo „Bóg” pozostaje niekwestionowanym i najwznioślejszym symbolem kultury zachodniej ${ }^{19}$, to jednak z wielu powodów i pod wieloma względami utraciło ono już tę niekwestionowaną i powszechnie znaną treść, jaką miało jeszcze niedawno. Wśród samych teologów pojawiają się wątpliwości co

18 Tomasz z Akwinu, In III Sententiarum d. 24 a. 1 q. 3 c.

19 Por. G. D. Kaufman, La question de Dieu aujourd'hui, Paris 1975, s. 119. 
do jego stosowania, czego dowodzi choćby posługiwanie się jego wątpliwymi synonimami. Najczęściej więc pojawia się w jego miejsce pojęcie Absolutu czy Rzeczywistości Najwyższej. Dochodzi do tego, że w taki sposób mówi się potem nawet w kazaniach lub modlitwie. Tak pojęty Bóg traci swoje imię, odniesienie do rzeczywistości ludzkiej, gubi się Jego działanie zbawcze, a więc pozostaje bez osobowego odniesienia do człowieka i sytuacji czasowej, w której on żyje; zostaje zakwestionowane Jego dogłębne zaangażowanie na rzecz człowieka ${ }^{20}$.

Można próbować sprecyzować i wyłożyć w sposób aktualizujący kwestię przedmiotu teologii. Historia rozwoju i interpretacji tego zagadnienia jest niezwykle pouczająca. Poszukiwania w tej dziedzinie zostały wielokrotnie podjęte i trafnie sformułowane również w nauczaniu papieża Jana Pawła II na temat teologii, które zasługuje na wielką uwagę ze względu na jego zasięg, częstotliwość, jak i wymiar doktrynalny. To nauczanie zostało potem wzmocnione przez deklarację Kongregacji Nauki Wiary o powołaniu teologa w Kościele Donum veritatis. Mówi więc ona, że przedmiotem teologii jest „Prawda, żywy Bóg i Jego objawiający się w Jezusie Chrystusie plan zbawienia" (nr 8).

Do tego określenia zostały włączone właściwie wszystkie elementy, które precyzują i aktualizują, wraz z odniesieniem do współczesnej wrażliwości, przedmiot teologii. Można powiedzieć, że to określenie opisuje go kontekście wrażliwości na perspektywę biblijną, a zarazem na wymagania współczesnej sytuacji duchowej. Pojęcie prawdy, mimo współczesnego zamieszania dotyczącego quaestio de veritate, ma podwójne odniesienie. Odsyła najpierw do Boga w Jego aspekcie prawdy, jako Veritas prima, na którym opiera się wybór wiary, którego człowiek poszukuje w swojej tęsknocie za prawdą i którą kieruje się w swoim życiu. Nie ulega wątpliwości, że w świetle Nowego Testamentu zbawienie człowieka polega na "poznaniu prawdy" (por. 1 Tm 2, 4). Bóg zwraca się do człowieka z orędziem Prawdy, mającej oczywiście charakter „zbawczy”,

20 Por. mój artykuł: Objawienie imienia Bożego i jego znaczenie egzystencjalno-teologiczne, „Tarnowskie Studia Teologiczne” 22 (2003), nr 2, s. 19-32. 
jak za wielowiekowym przekonaniem Kościoła stwierdził II Sobór Watykański w konstytucji Dei Verbum (nr 11). Taka prawda w najwyższym stopniu interesuje człowieka, ponieważ decyduje o jego życiu i jego ostatecznym przeznaczeniu. Pojęcie prawdy odsyła następnie do wspomnianego już aspektu uporządkowania właściwego dla wiary i jej aktualizacji. Odniesienie do prawdy w samym przedmiocie teologii ma w sobie również bardzo znaczącą nośność "dialogiczną", ponieważ wyraźnie otwiera teologię na inne nauki. Wszystkie nauki łączy poszukiwanie prawdy, nawet jeśli odwołują się one do innych kryteriów w jej określaniu. Z punktu widzenia współczesnej metodologii jest to zresztą uprawnione. W tej perspektywie warto wziąć pod uwagę postulat sformułowany przez Międzynarodową Komisję Teologiczną w dokumencie Komunia i stużba. Osoba ludzka stworzona na obraz Boży: „Na teologach, pełniących swoją służbę administratorów poznania, spoczywa zadanie usytuowania współczesnego poznania naukowego w ramach chrześcijańskiej wizji wszechświata stworzonego" (nr 66). Pojęcie prawdy łączy więc w jedną całość specyfikę objawienia chrześcijańskiego, instancję antropologiczną i kwestię naukowości.

W przytoczonym określeniu przedmiotu teologii ważne sprecyzowanie dotyczy samego Boga, chodzi mianowicie o „Boga żywego”, a więc nie jakiś bezosobowy i abstrakcyjny Absolut, oraz o Jego „konkretyzcję" zbawczo-chrystologiczną, czyli Boga Jezusa Chrystusa. Również w tym przypadku mamy do czynienia z niewątpliwym odniesieniem do zakorzenionego w myśli ojców tomistycznego rozumienia teologii jako scientia salutis, chociaż sformułowanego w sposób bardziej biblijny i egzystencjalny zarazem. Pomijając dyskusje dotyczące przedmiotu teologii, które toczono w ostatnim wieku, wydaje się, że ta propozycja stara się także odnieść do sytuacji duchowej dzisiejszego wierzącego, który zarówno odczuwa brak, jak również domaga się obecności Boga widzianego w relacji do swojego życia i do świata. Ujęcie tajemnicy Boga w perspektywie historii zbawienia wypełnionego w Jezusie Chrystusie nabiera więc szczególnej wymowy, gdyż wskazuje ona na zasadniczą więź istniejącą między Bogiem i człowiekiem oraz teocentrycznie ukierunkowuje całe życie człowieka. 
W czym wyrażałaby się pastoralność w tak ujmowanym przedmiocie teologii? Przede wszystkim tak rozumiana teologia w większym stopniu byłaby wiedzą ze względu na człowieka. Jakkolwiek tak zwany "zwrot antropologiczny” w teologii nie wytrzymuje próby czasu, to w ostatnim czasie okazało się, że w antropologii - jak stwierdził Karl Barth - rzeczywiście można „znaleźć coś teologicznie decydującego" ${ }^{21}$. Antropologia wniosła bardzo dużo do teologii, chociaż - wydaje się - zyskuje ona pełne znaczenie właśnie w perspektywie teologii, a zwłaszcza chrystologii. Warto jednak mieć na uwadze, że odpowiednio ujęta teologia wnosi bardzo wiele w życie człowieka, kształtując jego obraz i jego działanie; wnosi zaś szczególnie dużo, gdy ukazuje ścisłą więź zachodzącą między Bogiem i człowiekiem.

Jednym z zasadniczych problemów dzisiejszego Kościoła jest rozejście się dróg wiary i życia. Ich zjednoczenie - jak już zaznaczono - może dokonać się tylko na gruncie wykazania, że między tymi rzeczywistościami istnieje coś, co pozwoli je mocno połączyć. Takim czynnikiem może być właśnie kwestia zbawienia oraz pojęcie prawdy zbawczej, która spełnia rolę pośredniczącą między poznaniem i życiem, między prawdą i etosem. Siła tych pojęć wynika z faktu, że łączą one wymiar obiektywny, którym jest prawda, z wymiarem osobowym i działaniowym, którym jest zbawienie. Tak ujęta teologia może rzeczywiście wpływać na urzeczywistnianie wiary w jej aktualnym znaczeniu dla życia człowieka, jak i ze względu na to, co za jej pośrednictwem ma być ostatecznie osiągnięte w wieczności.

\section{TREŚĆ WYKŁADU TEOLOGICZNEGO}

Określony wyżej przedmiot teologii ma równocześnie bezpośrednie przełożenie na treści, które powinna dowartościować teologia w swoim wykładzie. Niejednokrotnie można odnieść wrażenie, że w dzisiejszej teologii systematycznej, podobnie jak i w rozmaitych dziedzinach nauczania religijnego, poszukuje się czegoś w rodzaju

21 K. Barth, Antologia, Milano 1983, s. 106. 
„zadziwienia świata". W związku z tym bardzo często podejmuje się jakieś „egzotyczne” zagadnienia, które niczego nie wnoszą do teologii w zarysowanym tutaj sensie, a pomija się zagadnienia zasadnicze i rzeczywiście formujące wiarę i życie chrześcijańskie. W ramach Zasad formacji kaptańskiej wyeliminowano bądź radykalnie ograniczono dziedziny wiedzy filozoficznej i teologicznej, które z tak rozumianym przedmiotem miały bardzo ścisły związek bądź do niego wprost należały; zlikwidowano na przykład filozofię religii, a wprowadzono religiologię, ograniczono wykłady z ety$\mathrm{ki}$, zmniejszono liczbę godzin w traktacie o stworzeniu, sakramentach, mariologii itd.

By wyjaśnić, na czym podlega problem, proponuję sięgnąć do wypowiedzi kard. Josepha Ratzingera: „Wiara nie ma trwałości sama przez się. Nie można jej po prostu zakładać jako czegoś już w sobie zamkniętego. Musi być przeżywana ciągle na nowo. A ponieważ jest aktem, który obejmuje wszystkie wymiary naszego życia, musi być także ciągle na nowo przemyśliwana i ciągle na nowo świadczona. Dlatego wielkie tematy wiary - Bóg, Chrystus, Duch Święty, łaska i grzech, sakramenty i Kościół, śmierć i życie wieczne - nigdy nie są tematami starymi. Są tematami, które ciągle przenikają nas coraz głębiej. Muszą na zawsze pozostać w centrum głoszenia, a więc i w centrum myśli teologicznej"22. Henri de Lubac mówił w podobnym sensie o zadaniach teologii: „Trzeba wyjaśniać, ciągle wyjaśniać - nawet ryzykując, że wyjaśnienia te są nudne, rozwlekłe, szkolarskie i ciężkie - najprostsze pojęcia"23.

Teologia musi zajmować się wciąż na nowo podstawowymi prawdami wiary. To jest jej pastoralność par excellence. Dla uzasadnienia tego faktu można odwołać się do bardzo znamiennego faktu. Podczas synodu biskupów z 1985 roku, poświęconego recepcji II soboru watykańskiego, liczni biskupi w swoich wypowiedziach szczerze zauważali, że wiele niepowodzeń w ich działalności duszpasterskiej wynika z tego, że nie mają one oparcia w treściach doktrynalnych. Próba wprowadzenia nowych propozycji duszpasterskich

22 J. Ratzinger, W co wierzy Kościót?, s. 117.

23 H. de Lubac, O naturze i tasce, s. 32. 
w oparciu o przesłanki socjologiczne bądź psychologiczne skończyła się niepowodzeniem. Dlatego właśnie jako antidotum zaproponowano wówczas opracowanie katechizmu dla Kościoła powszechnego, który wypełniłby ten dotkliwy brak. U nas reforma studiów teologicznych w ramach formacji kapłańskiej poszła po tej linii, która na Zachodzie już dawno upadła, czego dowiódł wspomniany synod. Jedyną dziedziną wiedzy, która została wzmocniona w odnowionych Zasadach formacji kapłańskiej, jest psychologia.

W dzisiejszej sytuacji duchowej powraca więc kwestia nadania pierwszeństwa prawdom, które określają, wskazują i utwierdzają drogę zbawienia. Mamy tutaj bardzo różnorodne możliwości i wzorce; sądzę, że powrót do Credo jako ośrodka teologii miałby decydujące znaczenie dla nadania wymiaru pastoralnego teologii. Urzeczywistnianie wiary w sposób niekwestionowany opiera się na tym, w co się wierzy.

Druga kwestia dotycząca treściowego aspektu teologii, która jawi się jako postulat ściśle związany z jej pastoralnością, dotyczy ukazania nierozerwalnej relacji zachodzącej między tym, kto wierzy, i tym, w co wierzy. Innymi słowy chodzi o wyjaśnianie aktu wiary i treści wiary w ich nierozdzielności. Może wydawać się to trochę abstrakcyjne, dlatego skonkretyzujmy zagadnienie. Otóż w wyznaniach wiary znajduje się formuła „ja wierzę”, jak również „my wierzymy". Mówimy więc o wierze jako akcie osobowym i darze Boga, czyli a kcie teologalnym. Wiara jest więc decyzją ukierunkowującą nasze życie - jest opcją egzystencjalną wywołującą skutki na wszystkich poziomach życia i aktualizuje się, gdy obejmuje całego człowieka. Ta wiara ma jednak treść: „Ja wierzę w B o ga”, a tego Boga ukazują konkretne treści doktrynalne - „prawdy wiary”.

Na czym polega problem? Zasadniczo na tym, że we współczesnej teologii istnieje dychotomia między tym, kto wierzy, i tym, w co on wierzy. Jest to dziedzictwo między innymi klasycznego podziału traktatów teologicznych. Mówiąc najogólniej, wykład wyglądał następująco. Najpierw w traktacie De fide bądź De virtutibus określano, czym jest wiara: aktem osobowym, rozumnym, wolnym, wspólnotowym itd., aby pokazać, że człowiek jest do niego zdolny i akt ten nie burzy jego struktury jako osoby. Następnie, skoro 
człowiek już wierzy i może wierzyć, to w takim razie przedstawiano przedmiot wiary w poszczególnych traktatach, czyli to, co powinien objąć swoją wiarą, czyli właściwie zaakceptować na gruncie swojej wiary. Aktu wiary nie łączono wstępnie z żadną konkretną treścią doktrynalną, która była zakładana niejako a priori; następnie w wykładzie poszczególnych traktatów do kwestii wiary już nie powracano, gdyż również a priori zakładano, że jest ona obecna. W takim wykładzie całej teologii, jak i poszczególnych traktatów, na ogół niebezpiecznie rozchodzi się związek między aktem wiary i treścią wiary. Aby przełamać tę dychotomię, trzeba by - tak sądzę - podejść do kwestii odwrotnie, drogą trochę trudniejszą i dłuższą, a mianowicie - wychodząc od treści wiary dojść do aktu wiary. Trzeba by zatem pokazać, w jaki sposób treści wiary wpływają na akt wiary i jakiego aktu wiary, w sensie jego przymiotów, się domagają. Po podjętych przeze mnie badaniach, opublikowanych w książce Uwarunkowania doktrynalne wiary, zatytułowanej w drugim wydaniu Credo. Przedmiotowe wymiary aktu wiary (Tarnów 2002), okazuje się, że postępując tą drogą, dochodzi się dokładnie do tych samych przymiotów, co w przypadku analizy aktu wiary w sobie ${ }^{24}$. Na przykład prawda wiary, mówiąca o stworzeniu świata przez Boga, bardzo jednoznacznie broni racjonalności i wolności człowieka w ogóle, a tym samym domaga się racjonalności i wolności wiary. Takie ujęcie pokazuje, że treść wiary niejako przystaje do człowieka i jego samego ma na względzie. Ponadto treść wiary rzeczywiście i najlepiej kształtuje to, jak człowiek wierzy i ma wierzyć.

W wykładzie teologii, wrażliwej na pastoralność, chodziłoby więc o możliwie szerokie ukazywanie, w jaki sposób poszczególne prawdy wiary kształtują rzeczywistość osobową i egzystencjalną oraz jak wpływają ukierunkowująco na podjęcie wędrówki zbawienia przez wierzącego.

W tym miejscu pojawia się również potrzeba dobrego opisania uwarunkowań osobowych, czasowych i sytuacyjnych, a więc

24 Por. K. Góźdź, Jezus. Twórca i Spetniciel naszej wiary, Lublin 2009, s. 219-225. 
szeroko rozumianego kontekstu, w którym żyje wierzący i Kościół. Prawdy wiary mogą być wyjaśniane skutecznie tylko i wyłącznie wtedy, gdy zna się kontekst kulturowo-społeczny i uwarunkowania, które wywołuje w człowieku, a które stanowią czynnik „determinujący wiarę", jak mówił św. Tomasz z Akwinu w przytoczonym na początku zdaniu.

Jeśli mówimy o treściach wiary i ich przedstawianiu w teologii, to pojawia się tutaj jeszcze jeden postulat o charakterze treściowo-metodologicznym. Chodzi o to, by ukazywać tajemnice wiary w ich wzajemnym powiązaniu i dopełnianiu się. Metoda teologiczna odwołuje się w tym przypadku do pryncypium określanego jako nexus mysteriorum. Jest to zasada znana już ojcom Kościoła. Święty Grzegorz z Nyssy stwierdził bardzo wymownie, że „siłą chrześcijaństwa” jest „wzajemna więź (koinonia) tajemnic i obyczajów"25. I Sobór Watykański, podając wskazania dotyczące ujmowania i przedstawiania treści wiary, zlecił teologom zadanie systematycznego szukania więzi zachodzących między poszczególnymi tajemnicami wiary, by na tym tle ukazywać wiarygodność wiary chrześcijańskiej i Kościoła ${ }^{26}$. Do zagadnienia powrócił papież Jan Paweł II w konstytucji apostolskiej Sapientia christia$n a($ art. $67 \mathbb{\$} 2)$.

Jednym z problematycznych aspektów dzisiejszej teologii, który wpływa również na obniżenie się jej wrażliwości pastoralnej, jest zbytnie rozbicie teologii. Wynika ono z przesadnego specjalizowania się teologów (teolog jednego zagadnienia/traktatu to nie teolog!), jak również bardzo zawężonych dążeń do syntezy teologii, która kiedyś była standardem. Dzieje się więc w praktyce tak, że na podstawowym poziomie studiów teologicznych student najczęściej nie jest w stanie dostrzec, w jaki sposób poszczególne traktaty teologiczne łączyłyby się ze sobą, jak by się wzajemnie uzupełniały i jak w całości miałyby kształtować rzeczywistość wiary. Ma to choćby taką konsekwencję, że i w duszpasterstwie sprowadza się wiarę do treści wybiórczych, czego dobrze dowodzi przepowiadanie

25 Grzegorz z Nyssy, Contra Eunomium: PG 45, 880B-C.

26 Por. I Sobór Watykański, konst. Dei Filius, cap. 4: DS 3016. 
kościelne, w którym brakuje integralności w wykładzie treści wiary, czy do bardzo zawężonego ich zastosowania, uzależnionego od osobistej wrażliwości duszpasterza.

W odpowiedzi na tę sytuację zachodzi potrzeba podjęcia wysiłku szukania wzajemnego przenikania się tajemnic wiary w ramach poszczególnych traktatów teologicznych. Ich dopełnieniem powinno stać się systematyczne podsumowanie poszczególnych cyklów studiów teologicznych odpowiednim wykładem syntetyzującym, który pokazałby właśnie jedność tajemnic wiary w perspektywie jedności życia chrześcijańskiego. Gdyby w tym dodatkowo mocno uwzględnić wątek egzystencjalny, przyczyniłoby się to do pokazania, w jaki sposób rzeczywistość teologiczna obejmuje całość życia ludzkiego, a więc byłby to ważny krok do pokazania jedności wiary, rozumianej całościowo, z życiem, również rozumianym w sposób całościowy. Byłby to ważny wkład wnoszony do kształtowania działalności duszpasterskiej w Kościele

\section{JAKOŚĆ DUCHOWA WYKŁADU}

Teologia jest wiedzą, do której natury należy jej przekazywanie. Wynika to z faktu, że jest to scientia fidei, a wiara ze swej natury domaga się przekazywania. Nikt nie wierzy tylko dla siebie, a więc nikt nie uprawia i nie studiuje teologii tylko dla siebie. Święty Tomasz z Akwinu widzi najwyższy poziom życia duchowego w „contemplata aliis tradere - to, co osiągnięte na drodze kontemplacji należy przekazywać innym" ${ }^{27}$. Aby skutecznie realizować przekaz w teologii, a tym samym kształtować nim rzeczywistość wiary i wpływać na jej aktualizowanie się, zachodzi potrzeba uwzględnienia w wykładzie teologii pewnych „jakości”, które można uznać za tkankę duchową jej tożsamości i rozwoju.

Pierwsza kwestia w praktycznym wykładzie teologii, która zasługuje na podkreślenie, dotyczy potrzeby nadania pierwszeństwa teologii systematycznej (spekulatywnej, kontemplacyjnej), w stosun-

27 Tomasz z Akwinu, Summa theologiae II-II q. 188 a. 6. 
ku do innych ujęć teologii. Święty Ignacy Loyola w Ćwiczeniach duchownych w regule jedenastej zapisał znamienne wskazanie: „Wychwalać naukę [teologii] pozytywnej i spekulatywnej. Jest bowiem raczej właściwością doktorów pozytywnych, na przykład świętego Hieronima, świętego Augustyna, świętego Grzegorza itd., wzbudzanie uczuć, żeby we wszystkim kochać Boga, naszego Pana, i służyć $\mathrm{Mu}$, natomiast cechą teologów scholastycznych, na przykład świętego Tomasza, świętego Bonawentury i Mistrza Sentencji itd., jest raczej określanie lub wyjaśnianie dla naszych czasów rzeczy koniecznych do zbawienia wiecznego i do lepszego zwalczania i ujawniania wszelkich błędów i fałszów"28.

Szczególna waga teologii spekulatywnej wynika z tego, że prowadzi ona do głębszego zrozumienia zagadnień dotyczących wiary. Teologia pozytywna (historyczna), która pokazuje, w jaki sposób wyłoniły się poszczególne kwestie doktrynalne, jest bardzo ważna, ponieważ kontekst pozwala na ich zrozumienie. Wiemy, jak bardzo ważny dla zrozumienia wypowiedzi dogmatycznych jest kontekst błędów, na które dawały one odpowiedź. Jest to jednak wiedza niejako in actu primo. Domaga się ona uzupełnienia, do którego dochodzi się na drodze kontemplacji intelektualnej, czyli dążenia do zrozumienia, mającego kluczowe znaczenie dla osobistego przyjęcia i przeżywania treści wiary.

W teologii nie wystarczy również samo odwoływanie się do autorytetu, jak w niejednym przypadku się proponuje, chcąc ułatwić sobie sprawę. Z punktu widzenia metodologicznego trzeba pamiętać, że powoływanie się na argument „z autorytetu” jest najsłabszym rodzajem uzasadniania i wyjaśniania. Trzeba stale mieć na względzie napomnienie sformułowane przez św. Tomasza z Akwinu: „Jeśli nauczyciel ukaże kwestię w oparciu o same argumenty z autorytetu, słuchacz zyska pewność, że tak jest rzeczywiście, ale nie zyska niczego na poziomie poznania lub rozumienia i odejdzie pusty" ${ }^{29}$. Mocne stwierdzenie, ale niezwykle prawdziwe. Można by z niego zrobić program nauczania teologii. Ma ono niewątpliwie także

28 Ignacy Loyola, Ćwiczenia duchowne, tłum. J. Ożóg, Kraków 1996, s. 150.

29 Tomasz z Akwinu, Quodlibet IV a. 18. 
wymiar pastoralny, skoro wiara ma być rozumna i rozumność jest warunkiem jej aktualizowania w codziennym życiu.

Nieodzowne z punktu widzenia pastoralnego byłoby włączenie do teologii następującego pryncypium: niczego nie zakładać, niczego nie narzucać, wszystko proponować. Rzeczma się tak, że zbyt często zakładamy, że wiele rzeczy w teologii jest po prostu znanych, zrozumiałych, oczywistych itd. Rezygnujemy więc z przedstawiania i wyjaśniania kwestii podstawowych, wstępnych, początkowych, wprowadzających. Oczywiście, nie rezygnując z tego, narażamy się - jak napisał Henri de Lubac - że nasze wykłady będą „nudne, rozwlekłe, szkolarskie i ciężkie”. Studenci teologii również nie chcą słuchać o tych kwestiach. Spotkałem studentów teologii, którzy chcieli poznać teologię von Balthasara lub Rahnera, a nie potrafili wymienić soborów powszechnych i problematyki, której dotyczyły.

Druga część wspomnianej zasady - niczego nie narzucać. Wielu teologów ulega dzisiaj pokusie nauczania swojej teologii, zapominając, że najpierw powinni wykładać rozumienie wiary Kościoła. Niejednokrotnie temu rozumieniu nadaje się zbyt osobiste i arbitralne interpretacje. W podstawowym cyklu studiów teologicznych powinno się zwracać wielką uwagę na ukazanie i właściwe zrozumienie tego, czego naucza Kościół. W ten sposób uniknęłoby się również niebezpieczeństwa nauczania czegokolwiek, ponieważ w takim przypadku należałoby wyjść od postawy poszukiwania, podstawowej postawy duchowej teologa.

Wyeliminowanie tych dwóch postaw zawężających i negatywnych przyczyniłoby się do przyjęcia zakorzenionej w Ewangelii postawy proponującej. Chodzi w niej nie tylko o tak zwane „pozytywne" przedstawianie treści wiary, ale o takie ich przedstawianie, które pokazałoby, że chodzi w nich o człowieka i są one dla człowieka jak najbardziej odpowiednie.

I wreszcie trzecia kwestia dotycząca jakości duchowej wykładu teologicznego. Musi to być wykład a polo ge ty c z ny, czyli nastawiony na zdecydowaną obronę wiary i doktryny chrześcijańskiej. Dzisiaj za mało uwzględnia się taki charakter wykład teologicznego i pomija się jego potrzebę w nowej sytuacji kulturowej i duchowej naszego świata. 
W 1934 roku Thomas S. Eliot w poemacie Chóry z „Opoki” pisał: „Kościół budowany jest zawsze, zawsze rujnowany od wewnątrz i atakowany z zewnątrz; Bo to jest prawo życia; pamiętajcie, że w czasach pomyślnych ludzie zaniedbywać będą świątynię, a czasu klęsk będą jej złożeczyć” ${ }^{30}$. Kilka lat temu René Girard pisał: „Ewangelie powinny nam pomóc $w$ przeciwstawieniu się nieodpartemu naciskowi antychrześcijańskich idei i doktryn, który wywierają na nas, skoro tylko stają się m od ne. [...] Wielu dzisiejszych chrześcijan uważa, że jest coś błędnego w obronie religii. Mówią [...] że jakoby jest ona religią autorytarną i despotyczną, z władzą narzucania swojej woli niewierzącym. Moja wizja obecnej sytuacji jest całkowicie inna. Wiara chrześcijańska jest atakowana ze wszystkich stron i ogromne siły komunikacji naszego wieku są istotnie zwrócone przeciw niej. W tej epoce nasza religia nie potrzebuje cenzorów, ale tego, by była broniona bardziej wyraźnie niż to było robione w ostatnich latach. Ci, którzy czują się zuchwali i oryginalni, powinni zdać sobie sprawę, że idą za jednym z najdalej sięgających i najbardziej okrutnych szaleństw całej historii" ${ }^{31}$.

Te wypowiedzi można zasadnie zakwalifikować jako „znak czasu”. Dlatego też trzeba w teologii wszechstronnie zapytać o to, na czym polegają dzisiejsze ataki na Kościół i jakie są ich założenia „teoretyczne”? To pozwoli później odpowiedzieć na pytanie, jak należy się im przeciwstawić? Uzasadnienia takiego teologicznego postawienia sprawy dostarcza znane sformułowanie z Pierwszego Listu św. Piotra: „Pana zaś Chrystusa uznajcie w sercach waszych za Świętego i bądźcie zawsze gotowi do obrony wobec każdego, kto domaga się od was uzasadnienia tej nadziei, która w was jest" $(3,15)$. Zdanie to nie tylko wskazuje na podstawę życia chrześcijańskiego i dostarcza jej uzasadnienia, ale także określa istotną wędrówkę, którą powinno podjąć życie chrześcijańskie, a szczególnie każda teologia. W każdym dziale wiedzy teologicznej jest zawsze

$30 \quad$ T. S. Eliot, W moim początku jest mój kres, przełożył, komentarzami i przypisami opatrzył A. Poniewierski, Warszawa 2007, s. 188.

31 R. Girard, La vittima e la folla. Violenza del mito e cristianesimo, Treviso 1998, s. $89,93$. 
miejsce, w którym zapoczątkowuje się i buduje ta dyscyplina, która pierwotnie - idąc po linii greckiego słowa, oznacza „odpowiedź na coś”, czyli „apologię" - została nazwana a pologetyką, a następnie, w optyce refleksji o podstawach, te ologią fundam en talną. Chociaż to przejście od apologetyki, która w pewnym okresie przyczyniła się do powstania tak zwanej teologii konfesyjnej, do teologii fundamentalnej może być uzasadnione samo w sobie, to jednak jest błędem zupełne wyeliminowanie z teologii jej wymiaru apologetycznego, który zawsze był w niej obecny. Pozytywne i proponujące przedstawianie treści wiary, na które zwrócono uwagę w kontekście II soboru watykańskiego, nie domaga się wyeliminowania mocnego uzasadnienia własnych przekonań religijnych w odniesieniu do innych czy też - co jeszcze gorsze - rezygnacji z wykazania błędu tezy przeciwnej. Święty Paweł w Liście do Filipian pisał, że zarówno on sam, jak i jego uczniowie uczestniczą w „obronie Ewangelii uzasadnionej dowodami" $(1,7)$. Bardzo wyraźnie nakazuje biskupowi Tymoteuszowi: „Wykazuj błąd, napominaj”, a dosłownie: „zawstydź, potęp” (2 Tm 4, 2).

Wymiar pastoralny zarysowanych wyżej jakości duchowych uprawiania teologii i wykładu teologicznego tkwi właśnie w tym, że mają one wzorcowy charakter dla urzeczywistniania autentycznego nauczania i działania w Kościele. Wszelka działalność duszpasterska w Kościele powinna odznaczać się tymi samymi przymiotami, które zostały tutaj pokazane w odniesieniu do teologii. W tym sensie teologia, jej nauczanie i studiowanie mogą mieć wymiar formacyjny, który przygotowuje i wprowadza do wszelkiej działalności eklezjalnej. 


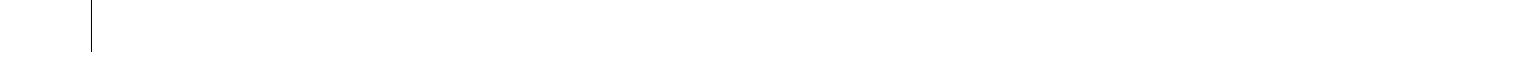


ROZDZIAŁ VII

米

\section{Nowa ewangelizacja a współczesne zawirowania antropologiczne}

Niecały miesiąc przed wyborem kard. Karola Wojtyły na Stolicę Piotrową, 22 września 1978 roku, w czasie wizyty biskupów polskich w Republice Federalnej Niemiec kard. Stefan Wyszyński wypowiedział w katedrze w Kolonii znamienne słowa: „Szukamy ewangelicznego języka, którym Episkopaty Europy mogłyby przemawiać do narodów, by zachować je w duchu miłości, sprawiedliwości i pokoju. Jest to język trudny, delikatny i oględny, ale niezbędny, abyśmy zdołali wypełnić wspólne zadanie ponownej ewangelizacji Europy"1. Wszystko wskazuje na to, że właśnie wtedy narodziła się idea nowej ewangelizacji, potwierdzona przez papieża Jana Pawła II w Nowej Hucie w czerwcu 1979 roku, a później ciągle rozwijana i pogłębiana. Idei papieskiej towarzyszyła od samego początku bogata refleksja teologiczna, która wypracowała wiele ciekawych propozycji dotyczaccych prowadzenia nowej ewangelizacji. Niestety, ciągle jeszcze brakuje jednoznacznej odpowiedzi, jak te ewangelizację rozumieć i jak ją podjąć w ramach działalności duszpasterskiej. Może efektem ostatniego synodu biskupów

1 Stefan Kardynat Wyszyński, Karol Kardynat Wojtyta. Spotkania w Republice Federalnej Niemiec, Poznań 1979, s. 44-45. 
będzie jakieś adekwatne sprecyzowanie tego zagadnienia, ponieważ taką intencję znajdujemy wyrażoną w Instrumentum laboris ${ }^{2}$.

\section{CO TO ZNACZY „NOWA” W ODNIESIENIU DO EWANGELIZACJI?}

Na nasz użytek trzeba w tym miejscu dokonać pewnego ogólniejszego sprecyzowania problematyki dotyczącej nowej ewangelizacji, szczególnie zaś trzeba zapytać, co znaczy w tym miejscu przymiotnik „nowa” i jakie są tego konsekwencje ${ }^{3}$. Mówiąc najprościej, ewangelizacja zawsze oznacza głoszenie Jezusa Chrystusa jako Zbawiciela wszystkich ludzi, prowadząc do osobistego przyjęcia Go przez wiarę, a także oznacza przekonujące pouczanie, jaką odpowiedź to przyjęcie powinno wzbudzić w człowieku, pozwalając mu realnie osiągnąć jego cel, którym jest zbawienie duszy (por. 1 P 1, 9). W tym ogólnym znaczeniu kwestia ewangelizacji nie budzi wątpliwości. Co jednak w odniesieniu do niej oznacza przymiotnik: nowa? Papież Jan Paweł II zaznaczył wyraźnie, że nie chodzi tutaj tylko o „ponowną” ewangelizację, czyli dokonanie, po upływie pewnego czasu, głoszenia Ewangelii po prostu ,jeszcze raz", by tam, gdzie przesłanie ewangeliczne zostało zapomniane lub pomniejszone, dokonać jego przypomnienia ${ }^{4}$. Takie ujęcie wydaje się zbyt proste i doświadczenia potwierdzają, że nie osiąga ono zamierzonego skutku. Dokonując wstępnego ukierunkowania nowej ewangelizacji, papież powiedział, iż chodzi o ewangelizację „nową w swym zapale, w swych metodach, w swym wyrazie”. Pozostaje jednak pytanie, kiedy te aspekty ewangelizacji będą rzeczywiście nowe.

2 Por. C. Parzyszek, Treść dokumentu „Instrumentum laboris” dla Synodu Biskupów o nowej ewangelizacji, „Ateneum Kapłańskie” 159 (2012), s. 491-502.

3 Por. R. Fisichella, La nuova evangelizzazione. Una sfida per uscire dall'indifferenza, Milano 2011.

4 Por. Jan Paweł II, Przemówienie do Rady Konferencji Episkopatów Ameryki Łacińskiej (CELAM) w Port-au-Prince (9 marca 1983 r.), „L'Osservatore Romano" (pol.) 4 (1983), nr 4, s. 29.

5 Tamże. 
Dla wydobycia nowości ewangelizacji, której domagał się papież Jan Paweł II i której wymaganie przypomina swoim słowem i decyzjami instytucjonalnymi, przede wszystkim powołaniem Papieskiej Rady ds. krzewienia Nowej Ewangelizacji, papież Benedykt XVI, zachodzi najpierw potrzeba spojrzenia historycznego na ewangelizację, by zapytać, w jaki sposób przebiegała ona w kolejnych wiekach, z czego wynikały jej sukcesy i czym były powodowane także doznawane porażki. Wydaje się, że niestety w poszukiwaniach dotyczących nowej ewangelizacji teologowie o tym po prostu zapomnieli, zbytnio przywiązując się do formułowania własnych propozycji, które miałyby nowatorsko wypełnić treścią papieską propozycję. Magisterium historiae jawi się tymczasem jako niezastąpione dla zmierzenia się z nową ewangelizacją. Próbę takiego spojrzenia, pozwalającą na wyprowadzenie ważnych wniosków, zaprezentowałem w innym miejscu, dlatego tutaj odwołam się tylko do dwóch wniosków ${ }^{6}$. Po pierwsze, nowych ewangelizacji w ciągu wieków było już bardzo wiele. Właściwie każda epoka, która wyróżniła się w dziejach ewangelizacji, jest naznaczona jakąś nową gorliwością czy też nowymi metodami i formami głoszenia Jezusa Chrystusa. Jest to pewna s tała, która powtarza się w dziejach Kościoła, nawet jeśli nigdy nie nazywano tych zjawisk „nową ewangelizacją”. Po drugie, tym, co wpisuje się w tę nowość, ukierunkowując nowy zapał, nowe metody i formy wyrazu, jest przede wszystkim wrażliwość na kontekst antropologiczno-kulturowy, w którym takie głoszenie się dokonuje. Jeden i ten sam Jezus Chrystus jest głoszony ludziom na gruncie odczytywania ich specyficznej otwartości na Niego i na Jego orędzie zbawcze. Znalezienie takiej otwartości nadaje po prostu „ton” prowadzonej ewangelizacji. Nowość ewangelizacji jest więc związana w punkcie wyjścia z pewną analizą antropologiczną oraz kulturową, która stanowi bezpośredni kontekst ewangelizacji, niejednokrotnie decydujący o tym, jakie przybierze ona formy i jakie zastosuje metody. Można w tym przypadku mówić o pojawianiu się w poszczególnych epokach czegoś w rodzaju interpretacji

6 Por. J. Królikowski, Doświadczenie świętych w dziejach Kościoła i nowa ewangelizacja, „Teologia w Polsce” 8 (2014), nr 1, s. 5-18. 
transkulturowej, nawet jeśli takie określenie nigdzie nie występuje. Co mam na myśli? Przez interpretację transkulturową rozumiem postawienie w centrum prowadzonych analiz dotyczących jakiegoś okresu czasu rozumienia filozoficznego (przede wszystkim metafizycznego) kultury danego czasu i wydobycie z niej perspektywy określającej jej istotę, nie dając się zwieść przez jej częściowe, a nawet tylko drugorzędne aspekty. Kultura jest najlepszym obrazem człowieka każdej epoki. Celem takiej analizy jest określenie sposobu zajęcia wobec tej kultury stanowiska na miarę człowieka, a w przypadku działań ewangelizacyjnych znalezienie w niej jakiejś wewnętrznej otwartości na orędzie ewangeliczne.

Kultura w swojej całości jest zbiorem wydarzeń, sposobów postępowania, zjawisk, wytworów ludzkich, sposobów korzystania z nich, które nieustannie splatają się ze sobą. Filozofia natomiast, będąc zjawiskiem refleksyjnym, oznacza próbę zobiektywizowanego uchwycenia tej całości, mając na względzie wprowadzenie jej do ludzkiej pamięci i kształtowanie za jej pośrednictwem przyjmowanych przez człowieka postaw. Interpretacja transkulturowa stara się więc rozumieć elementy kultury za pośrednictwem pojęć, które zawsze zakładają odniesienie do człowieka oraz do jego wrażliwości, przede wszystkim o charakterze metafizycznym i etycznym. Taka interpretacja jest niezastąpionym elementem rozumienia człowieka w konkretnej epoce dziejowej, w której jest zanurzony i która wywiera na niego swój wpływ. Takie rozumienie jest właściwie elementem organizującym metodologii przekazu jakiejkolwiek treści, jeśli zakłada się, że powinien być skuteczny. Dzisiejsze nauki, które zajmują się przekazem treści i wypracowują jego strategie, stwierdzają tę prawidłowość, czyniąc z niej niemal jedyny dogmat. Jeśli chce się skutecznie coś przekazywać, trzeba przede wszystkim rozumieć całościowo kontekst, w którym żyje człowiek i który pozwala odkryć jego specyficzną wrażliwość, by dostrzec, w jaki sposób jest on otwarty na treść do przekazania.

Tym, co stawia wymagania każdemu przekazowi i co go decydująco warunkuje, jest więc kontekst kulturowy. Ewangelizacja, która, właściwie biorąc, jest przekazem, nie może tego faktu nie uwzględniać w swojej metodzie. Ciągle mając tę samą treść, którą 
jest Jezus Chrystus Zbawiciel, urzeczywistnia się ona w nieustannie zmieniającym się kontekście, który bezpośrednio wpływa na wrażliwość człowieka, a tym samym warunkuje przyjmowanie przez niego przekazywanych mu treści. Przychodzą więc nowe pokolenia żyjące w nowym klimacie kulturowym i odznaczające się nową wrażliwością. Jeśli zatem chce się im przekazać coś istotnego, trzeba przede wszystkim zbadać aktualną kulturę, w której zostali ukształtowani i w której żyją, by móc określić wrażliwość poszczególnych ludzi, a tym samym także opowiedzieć na pytanie, w którym miejscu ta wrażliwość jest otwarta na Jezusa Chrystusa.

W świetle tego, co zostało tu powiedziane - moim zdaniem nowa ewangelizacja jest fundamentalnie kwestią o charakterze filozoficzno-teologicznym. W decydującym stopniu chodzi w niej o to, by w oparciu o analizę transkulturową, patrząc na dzisiejszego człowieka zanurzonego w bardzo specyficznym świecie z jego własną sytuacją duchową i kulturową, zapytać, w jaki sposób jest on otwarty na Ewangelię Jezusa Chrystusa. Dopiero na tym tle można efektywnie poszukiwać nowego zapału, nowych metod i nowych form. Że jest otwarty, jest faktem oczywistym. Trzeba tę otwartość tylko bliżej określić, a tym samym odpowiedzieć, jak uwzględniając ją i wiążąc ją z zaproponowaną metodą działania, można przekazywać konkretnemu człowiekowi Jezusa Chrystusa i Jego orędzie. Magisterium historiae dowodzi, że właśnie tak czyniono $\mathrm{w}$ ewangelizacji prowadzonej w przeszłości. Potwierdzają to choćby kazania, w których przejrzyście widać, że właśnie zależnie od aktualnego kontekstu kulturowego konkretyzowano przekaz orędzia chrześcijańskiego. Na przykład raz bardziej zwracano uwagę na Jezusa Chrystusa jako źródło nadziei, innym razem jako Pantokratora, któremu podlega cały kosmos, innym razem jako Lekarza, leczącego rozmaite ludzkie choroby, a jeszcze innym razem, w epokach chaosu obyczajowego, ukazywano Chrystusa jako Prawodawcę itd. Jakiego Jezusa Chrystusa oczekuje dzisiejszy świat? W którym „miejscu”, patrząc na dzisiejszego człowieka, widać tę otwartość i wrażliwość, która poniekąd na Niego oczekuje i stanowi punkt wyjścia do przyjęcia Go, by potem złączyć z Nim całe swoje życie? 


\section{DZISIEJSZY CZŁOWIEK}

Podstawowym problemem kulturowym i przedmiotem poszukiwań na polu kultury jest i powinien być dzisiaj człowiek. Ta wnikliwa obserwacja Kanta zachowuje ciągle swoją aktualność i nie należy jej lekceważyć ${ }^{7}$. Z wyżej przytoczonych racji trzeba ją uwzględnić także w podejmowaniu zagadnień dotyczących ewangelizacji. Celem głoszenia Jezusa Chrystusa jest przede wszystkim to, aby człowiek był zbawiony. Ewangelizacja zmierza do odnalezienia przez człowieka samego siebie, a zbawienie - odczytywane w kluczu antropologicznym - nie jest niczym innym niż osiągnięciem przez człowieka ludzkiej pełni, która jest możliwa tylko w Bogu. Zbawienie jest drogą prowadzącą do osiągnięcia pełnego człowieczeństwa. Już św. Ignacy Antiocheński bardzo jednoznacznie odkrył ten fakt, gdy pisał w liście do Rzymian: „Wybaczcie mi, bracia, nie przeszkadzajcie mi żyć, nie chciejcie, abym umarł; tego, kto pragnie należeć do Boga, nie wydawajcie światu, ani nie zwódźcie go materią. Dopuśćcie, bym otrzymał czyste światło. Kiedy tam dojdę, stanę się człowiekiem. Pozwólcie mi naśladować mękę mojego Boga".

Na czym polega dzisiaj zasadniczy problem kulturowy? Przede wszystkim na tym, że nie mamy do dyspozycji jakiejś ogólnie akceptowanej antropologii filozoficznej, która formułowałaby jasną odpowiedź na pytanie, kim jest człowiek - kim jest przynajmniej w najogólniejszym znaczeniu, to znaczy wskazującą, co wyróżnia człowieka i co jest wspólne wszystkim ludziom. Oczywiście chodzi o odpowiedź uwzględniającą aktualne pytania, niepokoje i aspiracje człowieka. Już w 1926 roku Max Scheler w eseju Człowiek i historia pisał: "Jeśli istnieje jakieś zadanie filozoficzne, którego rozwiązania nasza epoka domaga się wyjątkowo pilnie, to jest nim [opracowanie] filozoficznej antropologii”" Wiek później możemy powiedzieć tylko,

7 Por. I. Kant, Anthropologie in pragmatischer Hinsicht, [w:] Kant's gesammelte Schriften, t. 7, Berlin 1917, s. 119.

8 Ignacy Antiocheński, List do Rzymian (6, 2-3), [w:] Pierwsi świadkowie. Pisma Ojców Apostolskich, tłum. A. Świderkówna, Kraków 1998², s. 130.

$9 \quad$ M. Scheler, Pisma z antropologii filozoficznej i teorii wiedzy, s. 150. 
że ten postulat jest jeszcze pilniejszy ze względu na to, co zostało nazwane w tytule zawirowaniami antropologicznymi. Paradoksem jest tylko to, że wszystko stało się w wieku, który upłynął pod znakiem „zwrotu antropologicznego". Ten brak antropologii filozoficznej ma swoje niebezpieczne konsekwencje także dla teologii i nauczania kościelnego ${ }^{10}$.

Owszem, refleksji antropologicznej mamy dzisiaj wiele, ale jej zasadniczym brakiem jest to, że chwyta tylko jakieś fragmenty człowieka, że bardzo często zajmuje się sprawami peryferyjnymi, podnosząc je do rangi sztuki, ale nie chwyta całego człowieka i każdego człowieka w jego własnym czasie i środowisku. Na usprawiedliwienie mówi się, że taka refleksja antropologiczna jest odzwierciedleniem „rozbicia” człowieka, które jawi się jako pewien ogólniejszy fakt. Diagnoza powtarza się od dziesięcioleci. Aleksander Sołżenicyn swoje przemówienie, niewygłoszone wprawdzie, przygotowane z okazji przyznania mu nagrody Nobla w 1970 roku, zatytułował Świat w rozsypce, przy czym tytułowym światem jest po prostu człowiek ${ }^{11}$. Papież Jan Paweł II nawiązał wyraźnie do tej niepokojącej diagnozy w encyklice Fides et ratio, która jest apelem skierowanym do filozofów i teologów, by na poważnie zająć się dzisiejszym człowiekiem. Taka diagnoza jest dzisiaj dość powszechnie podzielana, nawet w kręgu tych, którzy do tej sytuacji doprowadzili, a teraz tęsknią za jednością człowieka i świata ${ }^{12}$.

Czy „rozbicie”, o którym mówi się w rozmaitych uwagach antropologicznych, można jednak uznać za differentia specifica człowieka? Oczywiście, że nie, gdyż jest to tylko jedna z okoliczności dzisiejszego świata i jedno z doświadczeń, które nakładają się na ludzką egzystencję. Perspektywa "rozbicia” może jednak rzeczywiście wiele wnieść do pogłębionego, na miarę nowych czasów

10 Por. Jan Paweł II, Przemówienie do uczestników Międzynarodowego Kongresu Teologii Moralnej (10 kwietnia 1986 r.), „L’Osservatore Romano” (pol.) 7 (1986), nr 5, s. 10.

11 Por. A. Sołżenicyn, Niewygtoszone przemówienie z okazji przyznania Nagrody Nobla za rok 1970, „Literatura na Świecie” 1994, nr 9, s. 308-324.

12 Por. J. F. Lyotard, La Confession d'Augustin, Paris 1998. 
i nowych wyzwań, rozumienia człowieka. Takie postawienie sprawy potrzebuje jednak uszczegółowionej odpowiedzi.

Na czym polega rozbicie dzisiejszego człowieka? W tym miejscu zamierzam wskazać tylko na jego podstawowe przejawy, będące znakiem zawirowań antropologicznych, których uwzględnienie wydaje się szczególnie znaczące w odniesieniu do kwestii ewangelizacji.

Pierwszy przejaw zilustruję cytatem z mało znanej wypowiedzi kard. Karola Wojtyły, sformułowanej w prywatnym liście do Henri de Lubaca: „Poświęcam moje bardzo rzadkie wolne chwile pracy, która leży mi na sercu, a która dotyczy metafizycznego znaczenia i misterium osoby. Wydaje mi się, że debata rozgrywa się obecnie na tym polu. Zło naszych czasów polega na pierwszym miejscu na rodzaju degradacji, rozcieńczeniu fundamentalnej jedyności osoby ludzkiej. To zło ma miejsce bardziej w porządku metafizycznym niż moralnym. Tej niekiedy planowanej dezintegracji ze strony ideologii ateistycznych musimy przeciwstawić, zamiast bezpłodnych polemik, coś w rodzaju «rekapitulacji» nienaruszalnego misterium osoby"13.

Mimo iż jest to uwaga, która została sformułowana pięćdziesiąt lat temu, dzisiaj jest ona aktualna w jeszcze większym stopniu. $\mathrm{Na}$ naszych oczach traci na znaczeniu antropologicznym, etycznym, kulturowym, prawnym itd. pojęcie osoby. Na próżno szukać go na przykład w Karcie Praw Podstawowych Unii Europejskiej. Fakt ten rodzi proste pytanie - czy „osobnik”, o którym mówi Karta, może być podmiotem i przedmiotem ustawodawstwa? W ten sposób, pomijając wszystkie inne aspekty, rozmywa się we współczesnej cywilizacji i kulturze jedyność człowieka. Nie chodzi tu o wykazywanie tego faktu, bo jest on raczej ewidentny, ale raczej o jego stwierdzenie. Jest więc pewne, że przejawem człowieka "rozbitego" jest odmawianie mu bycia osobą, czyli przymiotu niepowtarzalności, jedyności, wyjątkowości, godności, a tym samym także wynikających z tego szczególnych prerogatyw, zwłaszcza moralnych, kulturowych i prawnych, jak i odpowiadających im zobowiązań. Jesteśmy bardzo dalecy od uznania za św. Tomaszem z Akwinu,

13 H. de Lubac, Mémoire sur l’occasion à mes écrits, Namur $1992^{2}$, s. 176. 
że człowiek jako istota mająca duszę i dzięki niej, a więc jako osoba, quodammodo est omnia ${ }^{14}$. To samo przekonanie można znaleźć również u Kanta, jeśli ktoś woli trzymać się jego antropologii, chociaż nie jest ono tak wyraźnie skonkretyzowane jak u Akwinaty.

Uznanie człowieka za osobę pociąga za sobą wiele konsekwencji jest podstawowym warunkiem podjęcia zaangażowania na rzecz siebie i na rzecz każdego człowieka, przede wszystkim w aspekcie osiągnięcia przez niego jego pełni i zapewnienia mu należnej ochrony. Można zdecydowanie powiedzieć, że osoba jest po prostu zobowiązaniem dla siebie i dla innych.

Drugim defektem dzisiejszej antropologii, rozbijającym integralne spojrzenie na człowieka, a tym samym sprawiającym, że poszukiwania antropologiczne mało wpływają na rzeczywistość, a zwłaszcza sytuację duchową naszych czasów, jest pomijanie w ich ramach kwestii „celu” człowieka - mówiąc językiem bardziej metafizycznym, bądź też jego „sensu” - mówiąc językiem bardziej fenomenologicznym. Święty Tomasz z Akwinu trafnie zauważył, że cel stanowi causa causarum, to znaczy jest przyczyną wszystkich przyczyn ${ }^{15}$. Już za pośrednictwem poszukiwań psychologicznych, co też na przykład uczyniono w ramach psychologii humanistycznej, można wykazać, że przypadku celu (sensu) mamy do czynienia z kluczową sprawą interesującą, a przede wszystkim integrującą bytowo i działaniowo człowieka, a zatem powinna być to również kluczowa sprawa antropologii filozoficznej i teologicznej. Tym, co - niestety - zdominowało współczesną antropologię, jest kwestia przyczyny sprawczej causa efficiens, a tym samym człowiek, nieco upraszczając, zostaje sprowadzony do robotnika, a nawet do robota.

Trzecim problemem, jawiącym się jako poważny brak we współczesnych poszukiwaniach antropologicznych, jest rozbicie wewnętrznej relacji zachodzącej między bytem i działaniem w człowieku, a tym samym utrata pewności etycznej. Jest to zrozumiałe, jeśli uwzględni się, że metafizyka jest dzisiaj w odwrocie, a opowiadanie się za jej potrzebą jest traktowane jako rodzaj „reakcyjności”

14 Por. np. Tomasz z Akwinu, De veritate q. 1 a. 1 co.

15 Por. tamże, q. 21 a. 3 arg. 3. 
w myśleniu ${ }^{16}$. Tego typu rozbicie degraduje z kolei wolność człowieka, której podstawowym i najwyższym wyrazem jest cnota, będąca „najwyższym rozumem”, jak trafnie stwierdził Zygmunt Krasiński w Psalmach przyszłości. Z rozbicia tej jedności dochodzi się do apoteozy grzechu, czyli w gruncie rzeczy ludzkiej pychy, a życie w świecie staje się nieludzkie. Gdy w 1991 roku papież Jan Paweł II przybył do Polski z orędziem wolności na miarę nowych czasów, wolności budowanej w oparciu o etos wyrażony w Dekalogu, powiedział wówczas: „To jest perspektywa naszych czasów. Pomiędzy wolnością, do której Chrystus nas wyzwolił i stale wyzwala, a odejściem od Chrystusa w imię tak często bardzo głośno propagowanej wolności. Wolność, do której Chrystus nas wyzwolił, to jedna droga. Druga droga to wolność od Chrystusa"17. Niejaki Dawid Warszawski na łamach „Gazety Wyborczej” z dnia 13 czerwca 1991 roku napisał polemicznie w kontekście papieskiej wizyty: „Wolność jest niepodzielna i zawiera w sobie wolność grzechu - a tylko człowiek wolny może być moralny". Można zapytać, czy była to tylko wypowiedź skierowane przeciw papieżowi, czy też przeciwko Temu, którego papież reprezentuje? W każdym razie była to otwarta deklaracja antychrześcijańska, a nawet antyludzka.

Z kwestią wolności i jej rozumienia jest ściśle powiązana kwestia antropologiczno-etyczna, jaką jest kwestia pokory. Możemy ją, a właściwie brak jej stawiania, uznać za czwarty przejaw zawirowania antropologicznego we współczesnej kulturze. Dzisiejsza sytuacja mocno wpływa na degradację pokory - wracamy w pewnym sensie do czasów presokratejskich, kiedy pokora była widziana jako słabość, a tym samym była odrzucana jako niegodna człowieka. Nobilitacja pychy (hybris) jest zjawiskiem bardzo widocznym we współczesnej kulturze. Warto mieć na względzie, że to przewartościowanie ma daleko idący wpływ na sytuację wiary chrześcijańskiej w świecie, ponieważ zakłada on pokorę jako właściwe miejsce

16 Por. J. Habermas, Nachmetaphisisches Denken. Philosophische Aufsätze, Frankfurt am Main 1988, s. 44.

17 Jan Paweł II, Homilia wygłoszona w czasie Mszy świętej w Olsztynie (6 czerwca 1991 r.), „L'Osservatore Romano” (pol.) 12 (1991), nr 5, s. 60. 
swoich narodzin i warunek swojego dojrzewania, pozostając oczywiście pierwszym warunkiem postawienia w ogóle przez człowieka problemu Boga. Warto w tym miejscu przytoczyć kilka zdań ze św. Tomasza z Akwinu, które podkreślają znaczenie pokory w życiu człowieka: Humilitas facit hominem capacem Dei ${ }^{18}$; Humilitas dicitur spiritualis aedifici fundamentum ${ }^{19}$; Ubi humilitas, ibi sapientia ${ }^{20}$; Tota enim lex nova consistit in duabus: in mansuetudine et humilitate ${ }^{21}$.

Wreszcie piąty problem, którego boją się współczesne poszukiwania antropologiczne, a tym samym boi się go współczesna kultura, co widać aź nadto wyraźnie, jest problem śmierci. Jest to tymczasem dla człowieka problem istotny w najbardziej ścisłym i radykalnym znaczeniu tego słowa. Śmierć dotyczy każdego człowieka i każdy, nawet jeśli nie od początku życia, jest nią żywotnie zainteresowany. Wobec niej, jak św. Augustyn wobec śmierci swojego przyjaciela, sam dla siebie staje się problemem ${ }^{22}$. Od poważnej antropologii wymaga się zatem, aby nie dyspensowała się od zajęcia się tym problemem odwołując się do epikurejskiego stanowiska, według którego, jeśli żyjemy, to śmierć nie ma znaczenia, a jeśli umarliśmy, to już przestała mieć znaczenie. Nie można również dramatu śmierci sprowadzić do groteski, jak czynią dzisiejsze media i kinematografia. Takie ujęcie jest poniżające dla autentycznego myślenia o nastawieniu egzystencjalnym, które przecież pretenduje do integralnego mówienia o człowieku, chwytając najbardziej krytyczne momenty jego egzystencji.

\section{PROPOZYCJE}

Karl Barth powiedział kiedyś słusznie, że w antropologii można „znaleźć coś teologicznie decydującego" ${ }^{23}$. Analizując zagadnienie

\footnotetext{
18 Tomasz z Akwinu, Super Matthaeum XI, 3.

19 Tenże, Summa theologiae II-II q. 5 a. 2.

20 Tenże, Super Matthaeum XI, 3.

21 Tamże.

22 Por. Augustyn, Wyznania (4, 4-8), tłum. Z. Kubiak, Warszawa 1992, s. 97-104.

23 K. Barth, Antologia, Milano 1983, s. 106.
} 
nowej ewangelizacji, można z pełnym przekonaniem odnieść do niej to, co powiedział szwajcarski teolog. Z antropologii można wyprowadzić wiele decydujących wniosków i postulatów pod adresem ewangelizacji. Antropologia widziana w szerszym kontekście kulturowym pokazuje nam otwartość człowieka na orędzie zbawcze oraz wyznacza pewne „współrzędne”, w których powinno się głosić treści chrześcijańskie. Chcąc mówić do człowieka w sposób zrozumiały i przekonujący, trzeba poniekąd zejść do jego poziomu i uwzględniać jego wrażliwość. O tej prawidłowości wiadomo od wieków, czego potwierdzenia można szukać już w pismach starego Arystotelesa. Ten poziom pozwala uchwycić refleksja antropologiczna.

Co wynika ze spojrzenia transkulturowego na ogólną sytuację, w której znajduje się dzisiejszy człowiek? Moim zdaniem rzecz bardzo obiecująca. Warto przede wszystkim odnotować, że właśnie te zasadnicze elementy, które opisują rozbicie dzisiejszego człowieka i wpływają na zawirowania we współczesnej antropologii, są zarazem tymi swoistymi „szczelinami” kulturowymi, w których wyraża się otwartość dzisiejszego człowieka na wiarę chrześcijańską. Zachowuje ona swój potencjał antropologiczny, czyniący ją stale nową, zdolną do wzbudzania nowych dzieł. „Słabe” punkty dzisiejszej sytuacji kulturowej i antropologicznej są równocześnie tymi, które u większości ludzi budzą wyjątkowe zainteresowanie i pobudzają do podejmowania nowych poszukiwań, tymczasem żadna współczesna wizja antropologiczno-kulturowa nie udziela w tej materii spójnych i satysfakcjonujących wyjaśnień. Dlatego dzisiejszy kontekst może być nawet widziany jako szczególna szansa dla ewangelizacji, ponieważ w orędziu ewangelicznym te słabe punkty nie tylko są uwzględniane, ale otrzymują bardzo szeroką odpowiedź, chwytającą istotnie ludzką wrażliwość i uwzględniającą ludzkie niepokoje. Co więcej, wiara chrześcijańska jawi się jako odpowiedź na te właśnie problemy, które zostały wyżej pokazane, niejako dostrzegając w nich kluczowe wyzwania, jakie stają przed człowiekiem.

W tym miejscu zwrócę ogólnie uwagę na niektóre aspekty treściowe orędzia chrześcijańskiego, które wychodzą naprzeciw dzisiejszej sytuacji kulturowej i poszukiwaniom współczesnego człowieka. 
Na pierwszym miejscu, w sensie ogólnym, należy podkreślić, że orędzie chrześcijańskie zawiera w sobie bardzo zasadnicze przesłanie antropologiczne, nastawione na osiągnięcie przez człowieka wewnętrznej pełni, integralności i spójności, obejmującej wszystkie etapy i wymiary jego życia. Byłoby dobrze, gdyby w ramach nowej ewangelizacji podkreślić, że chodzi w niej właśnie o człowieka i jego pełnię, która jest możliwa do osiągnięcia tylko w ramach osobistej relacji z Bogiem. Już w deklaracji końcowej ogłoszonej przez Specjalne Zgromadzenie Synodu Biskupów poświęconego Europie (1991) z dużym wyczuciem personalistycznym zapisano na temat nowej ewangelizacji: „Ta ewangelizacja jest świadomie nazwana nową, ponieważ Duch Święty ciągle ukazuje nowość słowa Bożego i duchowo ożywia ludzi (por. $1 \mathrm{~J} 3$, 2). Jest ona również nowa, ponieważ nie jest związana na stałe z żadną określoną cywilizacją, jako że Ewangelia Jezusa Chrystusa może promieniować na wszystkie kultury. Prawda, że «Bóg cię kocha, Chrystus przyszedł dla ciebie», stanowi istotę ewangelizacji” ${ }^{24}$. To „dla ciebie”, czyli bezpośrednie zwrócenie się Boga do człowieka, powinno być widziane jako bardzo ważny element głoszenia orędzia chrześcijańskiego, odpowiadający zapotrzebowaniu człowieka na uznanie jego indywidualności i potrzeby bezpośredniości. Oznacza ono między innymi, że człowiek w osobistej i osobowej relacji z Bogiem i Jezusem Chrystusem znajduje swój fundament bytowy, umożliwiający mu jego spełnie$n^{25}$. W tym miejscu można także sformułować przestrogę dotyczącą unikania w głoszeniu chrześcijańskim wszelkich ogólników antropologicznych, ponieważ oddalają one realnego człowieka od głoszonych treści, rozmywając je w abstrakcji odległej od ludzkich odczuć i poszukiwań, degradującej potrzebę nawiązania komunikacji i bezpośredniości, jak stale podkreślał Søren Kierkegaard.

24 Specjalne Zgromadzenie Synodu Biskupów poświęconego Europie (1991), Deklaracja końcowa Abyśmy byli świadkami Chrystusa, który nas wyzwolit, II, 3, „L'Osservatore Romano” (pol.) 13 (1992), nr 1, s. 47. Deklaracja cytuje w tym miejscu adhortację Jana Pawła II Christifideles laici, 34.

25 Por. J. Królikowski, Jezus Chrystus objawia człowieka człowiekowi, „Tarnowskie Studia Teologiczne" 30 (2011), nr 2, s. 55-70. 
Orędzie chrześcijańskie jest następnie orędziem, które wyraźnie ukazuje jedyność człowieka i jej broni, gwarantując nie tylko jej zachowanie, ale także ostateczne wypełnienie w najwyższym stopniu. Na straży tego faktu stoi pojęcie osoby. Człowiek pierwotnie nie jest jednostką, nie jest osobnikiem ani nawet nie jest podmiotem, ale jest istotą mającą byt przez się, wyrażający się w tym, że jest jeden ciałem i duszą, otwarty na ty ludzkie, szczególnie w wymiarze relacji mężczyzna-kobieta, oraz na Ty boskie, w którym osiąga swoją pełnię. Osoba jest poniekąd wszystkim, co potwierdza swoimi indywidualnymi i niepowtarzalnymi relacjami, za pośrednictwem których urzeczywistnia się także jako jednostka i jako podmiot.

W punkcie wyjścia wiara chrześcijańska jest nastawiona celowo, a więc już z samego tego powodu jest w najwyższym stopniu sens otwórcza. W tym znaczeniu jawi się jako odpowiedź na pytanie najbardziej nurtujące ludzi naszych czasów, którzy zanurzeni w świecie przedmiotów i zmuszani do coraz cięższej pracy, pytają o sens swojej osobistej egzystencji i sens istnienia człowieka w ogóle. Biorąc pod uwagę zarówno natarczywość tego pytania, jak i niejednokrotnie pojawiające się patologie, wynikające z tego, że brakuje na nie odpowiedzi, możemy pokornie, ale również zdecydowanie powiedzieć, że w tym wszystkim odżywa ukryte wołanie o wiarę chrześcijańską. Bardzo wyraźnie ukazał tę perspektywę wiary papież Jan Paweł II w encyklice Fides et ratio.

Etyczny wymiar chrześcijaństwa, chociaż stale jest naznaczony prowokującym pytaniem, sformułowanym już przez apostołów: "Jakże to możliwe?", również odznacza się dużą siłą oddziaływania i przekonywania. Należałoby w jego prezentowaniu zwrócić większą uwagę na to, w jaki sposób etos odpowiada godności człowieka i jak ją potwierdza oraz w jakim znaczeniu ma on wymiar uniwersalny, to znaczy jest skierowany do każdego człowieka i dla każdego możliwy do realizacji. Wydaje się, że w tej chwili właśnie w tym punkcie sytuuje się najsłabszy punkt głoszenia kościelnego, gdyż mało zwraca się uwagę na ten właśnie godnościowy potencjał etosu ewangelicznego. W głoszeniu etosu trzeba także zwracać uwagę na jego pewność, która rodzi się na gruncie jego odpowiedniości dla człowieka i sposobu osiągnięcia pełnej wolności. 
Aby pokazać wymiar godnościowy i uniwersalny etosu chrześcijańskiego, w jego centrum należy postawić kwestię wolności, która jest kwestią typowo chrześcijańską, gdyż to orędzie ewangeliczne jako pierwsze zwróciło się do człowieka z „prawem wolności" (Jk 2, 12) i tylko to orędzie daje spójną i uniwersalną odpowiedź na pytanie, w jaki sposób człowiek może wyrazić się jako istota wolna, a w końcu osiągnąć pełnię wolności. Oczywiście, aby ta odpowiedź zyskała odpowiednie uznanie i przyjęcie nastawione na urzeczywistnienie egzystencjalne, domaga się pogłębienia metafizycznego. W tym punkcie kryje się także ważna inspiracja do spojrzenia na śmierć człowieka, która musi być stale widziana jako quaestio princeps wszelkich poszukiwań antropologicznych i religijnych. Człowiek, ponieważ jest wolny, może stanąć godnie wobec tego wyzwania, jakim jest śmierć, a także odkryć, że śmierć nie jest końcem. 


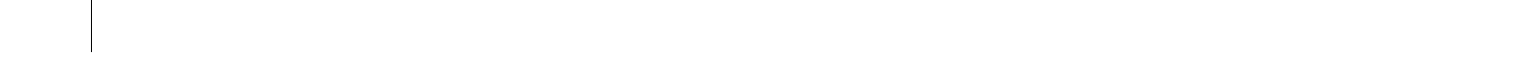


ROZDZIAE VIII

米

\section{Teologia między ortodoksją i ortopraksją}

\section{ROZZIEW MIĘDZY TEORIĄ I PRAKTYKĄ}

Podejmowany problem dotyczy metody teologii systematycznej, w której pojęcia or todoksji i or to praksji często znajdują się w stanie napięcia, a nawet wprost przeciwstawienia, przede wszystkim w takiej mierze, $\mathrm{w}$ jakiej przez ortodoksję rozumie się przylgnięcie do prawdy wiary jako czystej wypowiedzi doktrynalnej, a przez praktykę rozumie się samo przeżycie apojęciowe, konkretne i historyczne wiary, bądź czyste działanie przekształcające struktury społeczne.

Geneza historyczna tego bardzo podstawowego problemu jest niezwykle złożona, przy czym jest również pewne, że pozostaje sprawą bardzo pilną przekroczenie rozejścia się dróg ortodoksji i ortopraksji. Wystarczy tutaj wspomnieć, że to rozejście się zostało zapoczątkowane w kontekście postępującej intelektualizacji teologii. Działo się to najpierw w wyniku odpowiadania przez teologię na wymogi statusu naukowego, którego domaga się jej obecność na uniwersytecie. Na tę intelektualizację niewątpliwy wpływ miało przyjęcie i rozpowszechnienie arystotelesowskiego pojęcia nauki, a następnie rozwinęła się ona w kontekście utrwalania się nowożyt- 
nej świadomości krytycznej. Ta świadomość zmierzała od początku do rozbicia dwumianu: fides (auctoritas) - ratio, który stanowił organiczną jedność u swoich początków, czyli wtedy gdy wiara była traktowana jako słuchanie i percepcja refleksyjna: intellectus fidei i fides quaerens intellectum. Efektem tego rozbicia jest przyznanie każdemu z dwóch biegunów tego dwumianu odrębnych kompetencji w odniesieniu do odrębnych dziedzin rzeczywistości, w następstwie czego doszło do wydzielenia dwóch sfer poznawczych: sfery racjonalno-naukowej (nauki przyrodnicze) i sfery podlegającej naukom humanistycznym, do której została włączona wiara pozbawiona racjonalności oraz zdominowana przez mistycyzm fideistyczno-apojęciowy. W tym kontekście, w metodzie teologii, obrona specyficznego statusu intelektualnego miała odniesienie zarówno do wymogu obrony własnej naukowości, jak i wymogu obrony noetycznych treści wiary w jej wartościach uniwersalnych i trwałych.

To podwójne zadanie prowadziło jednak teologię akademicką do oddalenia się od kultury czasu, będącego wynikiem kultywowania kategorii pojęciowych, które okazywały się coraz bardziej obce i nie pozwalały się zintegrować. Rzeczywiście, wobec historycznej koncepcji prawdy, która zaczęła zagrażać uniwersalnej wartości stwierdzeń wiary i jawiła się jako wielka apostazja czasów nowożytnych, teologia dążyła do wzięcia na siebie roli obronnej w stosunku do wiary. W ten sposób stopniowo utrwalała rygoryzm własnego języka, zamykając się coraz bardziej w obronie ortodoksji rządzonej koncepcją prawdy rozumianej jako „poprawność wypowiedzi dogmatycznych". Coraz bardziej odczuwana w Kościele troska o ocalenie obiektywnych treści wiary (fides quae) przed ich zarażeniem i rozbiciem dzięki surowej ochronie pojęciowej znalazła wtedy oparcie w neoscholastycznej metodzie teologicznej, uważanej w ramach tego zadania za coraz bardziej funkcjonalną i nieodzowną do obrony wiary. Rosnąca opozycja wobec prądów myśli nowożytnej wchodzącej do Kościoła, szczególnie w ramach modernizmu, czyniła tę tendencję szczególnie widoczną.

W tej sytuacji, której cechą charakterystyczną była dominująca troska o ortodoksję doktrynalną, zakres praktyki i doświadczenia wiary pozostawał coraz bardziej wyobcowany z teologii akademic- 
kiej i był coraz bardziej przejmowany przez tak zwaną te ologię praktycz ną, która wychodząc od swojego pierwotnego zadania, jakim była formacja pasterzy, i przechodząc przez pierwsze dążenia do określenia statusu uniwersyteckiego, szła jednak po omacku, starając się przezwyciężyć coraz bliższe niebezpieczeństwo pewnego pragmatyzmu duszpasterskiego związanego ze strukturą dyskursu nienaukowego. Aż do II soboru watykańskiego pogłębiał się rozziew między metodą teologii bardziej zatroskanej o ortodoksję czysto doktrynalną, związaną z precyzyjnymi formułami, niepodlegającymi biegowi wydarzeń ludzkich, jako pewnym punktem odniesienia dla obrony wiary przed herezją i metodą praktycznego dyskursu teologicznego, zdominowanego uwagą skierowaną na człowieka, do którego się zwraca. Tak zwany „zwrot antropologiczny" okazał się czynnikiem rzeczywiście decydującym dla teologii. Stwierdzenie Rudolfa Bultmanna: „Jeśli chce się mówić o Bogu, to musi się mówić o człowieku"1, nie budzi dzisiaj niczyjej wątpliwości.

Wobec tej problematycznej sytuacji II Sobór Watykański uwypuklił potrzebę odnowionej metody dogmatycznej, która odzwierciedlałaby bardziej dynamiczną świadomość Kościoła oraz stale zwróconą - z jednej strony - na wydarzenie chrystologiczne swoich początków, z których czerpie swoją tożsamość, a z drugiej strony na świat, do którego zwraca się jego posłanie. Dlatego więc, jeśli pierwotne słowo objawienia na nowo odzyskało swoje pierwszorzędne miejsce w teologii, stając się jego "duszą"2, sytuacja przeżywana przez podmiot wiary i sytuacja adresatów głoszenia chrześcijańskiego stała się równie ważna. W tym kontekście formuła dogmatyczna nabrała nowego znaczenia - nie jest już ani punktem wyjścia, ani punktem dojścia dyskursu teologicznego, ale raczej koniecznym momentem pośrednim, istotnie związanym z przeszłością i teraźniejszością Kościoła oraz otwartym na jego przyszłość.

Jest jasne, że problem metody teologii dogmatycznej odzwierciedla w tym kontekście istotne i ciągłe zadanie przekazywania

1 R. Bultmann, Welchen Sinn hat es von Gott zu reden?, [w:] tegoż, Glauben und Verstehen. Gesammelte Aufsätze, t. 1, Tübingen 1933, s. 28.

2 Por. II Sobór Watykański, konst. Dei Verbum, 24. 
i języka (hermeneutyki), które jest zarazem doktrynalne i praktyczne. Ten podwójny wymóg został zauważony przez papieża Pawła VI w przemówieniu otwierającym drugą sesję soboru, gdy stwierdzał, że czyni swoim ukierunkowanie dane przez swojego poprzednika Jana XXIII, w przekonaniu, że doktryna chrześcijańska nie powinna być tylko prawdą badaną przez rozum oświecony przez wiarę, ale powinna być słowem rodzącym życie i działanie, przez co nie należy ograniczać autorytetu Kościoła do potępienia błędów, które go obrażają, ale trzeba go rozciągnąć na głoszenie nauczania pozytywnego i żywotnego, którym on jest płodny ${ }^{3}$.

Wymóg odwołania się teologii do doświadczenia i do „praktyki” życia wiary w jego wielorakich formach wyrazu - zarówno duchowych, jak i kulturowych, zarówno indywidualnych, jak i wspólnotowych i społecznych, powraca stale w naszych czasach nie tylko z powodu posłania duszpasterskiego Kościoła i duszpasterskiego charakteru jego nauczania, ale także z powodu potrzeb wyłaniających się w ramach wspólnot chrześcijańskich zaangażowanych w różnych częściach świata w przekształcanie struktur społecznych. W tym wypadku teologia jest rozumiana nie tyle jako dyskurs intelektualny wiary o historii, ile jako "praktyka” w historii.

Miejsce społeczne, w którym teolog uprawia teologię, oddziałuje zatem na miejsce epistemologiczne, czyli na to, jak uprawia teologię, w wyniku czego to, co czynić, staje się przedmiotem tego, co myśleć. Pod takimi naciskami język ortopraksji jest narażony na przyjęcie znaczenia antytetycznego w stosunku do ortodoksji i do treści noetycznych, jakie prawda wiary niesie ze sobą, wpływając na niebezpieczne zachwianie równowagi w metodzie teologii, opowiadając się w sposób bardziej lub mniej bezpośredni za absolutną dominacją praktyki. Widać to na przykład w następującej wypowiedzi: „W obecnej sytuacji jesteśmy zmuszeni do rozwinięcia praktycznych modeli działania, nie mogąc oczekiwać pomocy ze strony ortodoksji. Wskazania ortodoksji są co najwyżej więzami [...] dlatego w miejsce ortodoksji związanej

3 Por. Paweł VI, Przemówienie Salvete, Fratres (29 września 1963), „Acta Apostolicae Sedis" 55 (1963), s. 854-858. 
w swoich schematach ze strukturami społecznymi i z przekroczonymi kontekstami duchowymi - przynajmniej w chwili obecnej powinna wyjść na pierwsze miejsce ortopraksja, która podtrzymuje wiarę przy życiu i dostarcza nowej podstawy życia dla przekształcenia ortodoksji, która stała się bezpłodna i została wydziedziczona"4.

\section{Z DOŚWIADCZEŃ PIERWOTNEGO CHRZEŚCIJAŃSTWA}

Zanim przejdziemy do wyznaczenia na dzisiaj teologii dogmatycznej niektórych kryteriów dotyczących relacji między ortodoksją i ortopraksją, nieodzowne będzie spojrzenie na pierwotną koncepcję prawdy i poprawności wiary $y^{5}$, jak również na koncepcję h ere zji w pierwotnym chrześcijaństwie ${ }^{6}$. Mamy już do dyspozycji znaczące wyniki badań w tej dziedzinie.

\subsection{IDEA PRAWDY}

Jeśli chodzi o ideę prawdy w Piśmie Świętym i w chrześcijaństwie pierwotnym, to trzeba zauważyć, że nie jest ona formułowana wyłącznie na gruncie czysto metafizycznym i logicznym. Prawda biblijna nie oznacza przede wszystkim sposobu bycia rzeczy, dotyczącego ich istoty poza czasem, ani nie oznacza też poprawności wypowiedzi. Pojęcia emunah i emet, które Septuaginta tłumaczy jako pistis i aletheia, wyrażają przede wszystkim postawę osób, które są stałe i mocne, jeśli odpowiadają na oczekiwania, jakie są wobec nich formułowane. Prawda odnosi się przede wszystkim do rzeczywistości, która wypełnia się w działaniu, przez co ktoś nie pomniejsza konkretnego oczekiwania lub wymagania

4 H. Halbfas, Linguaggis ed esperienza nell'insegnamento della religione, RomaBrescia 1970, s. 13-14.

5 Zasadnicze znaczenie posiada w tej kwestii: I. de la Potterie, La vérité dans saint Jean, t. 1-2, Rome 1977.

6 Por. G. L. Prestige, Fathers and heretics. Six studies in dogmatic faith with prologue and epilogue, London 1958; M. Simonetti, Ortodossia ed eresia tra I e II secolo, Soveria Mannelli 1994. 
kierowanego pod jego adresem oraz potwierdza tę ufność, jaka jest w nim pokładana. Łączy się ona ze słowe m i aktualizuje się w słowie, o ile okazuje się skuteczne, tworząc to, co oznacza?

W przypadku Boga emunah jest determinacją i wiernością, z jaką Bóg Izraela dotrzymuje danego raz słowa oraz prowadzi do wypełnienia w historii tego, co powiedział. Stara się wypowiedzieć nośność historyczno-konkretną wydarzenia, które okazuje się prawdziwe w czasie. Chodzi w niej zawsze o coś, co wydarzyło się lub się wydarzy, a nie o coś, co z natury jest, jest tak i tak powinno być. Prawda, podobnie jak całe objawienie, jest w Biblii rzeczywistością traktowaną jako historia ${ }^{8}$. Prawda domaga się więc urzeczywistnienia w czasie i w biegu wydarzeń. W ten sposób „prawdą Bożą" jest to mówienie i to działanie, które potwierdza, że Bóg jest Bogiem ${ }^{9}$ - przez swoje słowo i swoje działanie Bóg potwierdza swój byt. Emeth Jahve odnosi się do Jego stałej wierności przymierzu: "Dziełem Jego są sprawiedliwość i słuszność" (Ps 110, 7; 115, 1-3).

Możemy powiedzieć, że w starożytnej koncepcji żydowskiej prawda wyraża nie tylko byt w sobie i przez się rzeczy, ale też ufność, jaką wyrażają ludzie lub Bóg w swoim sposobie działania. Wynika z tego charakterystyczny aspekt żydowskiego pojęcia prawdy, która nie tylko może być poznana, powiedziana, usłyszana bądź ewentualnie niepoznana, ukryta lub odrzucona, ale powinna być wprowadzona w czyn - powinna wypełnić się, czyli dojść do pełni. W tym kontekście prawda jawi się jako r ze czywist ość historyczna i postawa praktyczna, faktyczna, które są nierozdzielnie ze sobą połączone. To odwołanie się do "czynić”, do „dokonywać się” otwiera koncepcję prawdy na przyszłość. Prawda nie jest czymś, co w jakiś sposób znajduje się pod lub za rzeczami i co osiąga swoją rzeczywistość wewnętrzną, wnikając w głąb rzeczy; prawdą jest to, co okaże się w przyszłości.

7 Szczególnie odzwierciedla się ta kwestia w psalmach; por. Ps 33, 9; 147, 15; Iz 48, 13.

8 Por. L. A. Schökel, Carattere storico della rivelazione, [w:] Atti della Settimana Biblica, t. 20, Brescia 1970, s. 31-56.

9 Por. Pwt 7, 9; Ps 36, 6; Iz 49, 7. 
W tym kontekście „prawda Boga” jest wydarzeniem, w którym konkretyzuje się plan zbawczy, obejmujący nie tylko zewnętrzną rzeczywistość faktów, ale odsłonięcie go za pośrednictwem słów poprzez które dokonujące się wydarzenie może być rozumiane jako "czyn Boży”. Nawet jeśli w tekstach biblijnych z późniejszego okresu wyraźnie dochodzi do głosu pewna tendencja obiektywizująca, w wyniku której pod wpływem tradycji mądrościowej prawda zostaje związana z nakazami Bożymi wyrażonymi w Torze (por. Ps 119), to nigdy nie zostaje zagubione tło „praktyczne” idei prawdy, która zakłada właśnie „czynienie” (aletheian poiein).

W Nowym Testamencie prawda Boża koncentruje się na wydarzeniu chrystologicznym jako szczycie samopotwierdzenia i wierności Boga Jego obietnicom, które wszystkie stały się „tak” (2 Kor 1, 20), dla których Jezus Chrystus jest „Amen” (Ap 3, 14). On jest „Prawdą” $(J 1,14 ; 14,6)$. W tym znaczeniu „prawda Ewangelii” lub „Ewangelia prawdy" (Ga 2, 5.14; Ef 1, 3; Kol 1, 5) wyraża głoszenie najwyższego wydarzenia, jakim jest działanie mocy Bożej w Jezusie Chrystusie uwielbionym. Nawet jeśli św. Paweł stosuje słowo „Ewangelia”, by określić nim „przekazaną naukę” (por. Rz 1, 1-2; 1 Kor 15, 3-5) - tę tendencję spotyka się szczególnie w listach pasterskich, w których pojęcie prawdy przyjmuje znaczenie „zdrowej nauki” ${ }^{10}$ - to jednak prawda Ewangelii nie redukuje się po prostu do poprawnej wypowiedzi. Treścią „zdrowej nauki” są centralne wydarzenia zbawcze (por. $1 \mathrm{Tm} 1,15$ ) i taka nauka narzuca się na mocy przepowiadania, które ogłasza prawo Boże na ziemi. Nauka pozostaje zawsze w relacji do postępowania moralnego ${ }^{11}$.

Jeśli więc - z jednej strony - „prawda” jako „zdrowa nauka” chroni praktykę wiary od błędów, to jest przecież prawdą, że poznanie prawdy nigdy nie przekształca się $\mathrm{w}$ wiedzę pojęciową - ona jest mądrością, która działa w życiu. Jest to praktyka, która określa więc bycie $\mathrm{w}$ prawdzie ${ }^{12}$. Szczególnie Jan kładzie nacisk na rolę prawdy w życiu wierzących. Prawda nie jest przedmiotem czystej kontem-

10 Por. 1 Tm 1, 10; 6, 3; 2 Tm 1, 13; 4, 3; Tt 1, 9.13; 2, 1.8 .

11 Por. Rz 12, 1-2; Flp 4, 8-9.

12 Por. X. Léon-Dufour, Agire secondo il Vangelo, Bologna 2003, s. 61-68. 
placji intelektualnej, ale domaga się elementu praktycznego, który ściśle łączy się z „czynieniem” lub „byciem czynionym”, co oznacza „czynienie własną prawdy, którą jest Chrystus”, „chodząc w prawdzie” (2 J 4; 3 J 3, 4). Ta „prawa wiara” jako praktyczne przylgnięcie do prawdy, którą jest sam Jezus Chrystus, dzięki której praktycznie dochodzi się do poznania „zdrowej nauki”, zakłada także życie w miłości braterskiej ${ }^{13}$ i życie w komunii z „my” apostolskim, bez którego nie ma komunii z prawdą „życia wiecznego” (1 J 1, 3). Nie przypadkiem właśnie $\mathrm{w}$ listach pasterskich, w których zauważa się akcent kładziony na znaczenie „zdrowej nauki”, stwierdza się ważność miłości, w wyniku czego ten, kto nie troszczy się o swoich braci, odrzucił wiarę i jest gorszy od niewiernego ${ }^{14}$.

\subsection{PRAKTYKA MIŁOŚCI}

Ważność praktyki miłości dla „prawej wiary” - ortodoksji - ukazuje się, wychodząc od chrześcijaństwa pierwotnego i przez długą część ery chrześcijańskiej, bardzo bezpośrednio w sposobie myślenia o wierze i herezji. Jak przekonująco wykazał Yves Congar, pojęcie wiary i her ezji w całym pierwszym tysiącleciu, w średniowieczu i jeszcze na początku epoki nowożytnej było bardziej eklezjologiczne niż dogmatyczne ${ }^{15}$. Nacisk kładziono nie tyle na jakąś określoną dziedzinę, o raczej ściśle określonych granicach, wypowiedzi „obiektywnych” odnośnie do treści wiary, ile raczej na postawę „podmiotową" samej wiary (fides qua) lub - odpowiednio - niewierności. Kościół i jego jedność były traktowane jako miejsce lub podstawowy sakrament zbawienia, dzięki czemu to, co nie zgadzało się z wiarą lub praktyką wspólnoty, było uważane za heretyckie. Idea herezji nie różniła się tak jasno od schizmy - kto zrywał ze wspólnotą kościelną, temu brakowało czystości wiary. Oznacza to, że herezja jest błędem doktrynalnym, wynikającym z zerwania komunii

13 Por. Jk 2, 14-19; 1 J 2, 4-6.9-10; 1 Kor 13, 2; 8, 2.

14 Por. 1 Tm 5, 8.

15 Por. Y. Congar, L'hérésie, déchirement de l'unité, [w:] L'Eglise est une. Hommage à Moehler, ed. P. Chaillet, Paris 1939, s. 255-269. 
eklezjalnej. Prawa wiara i praktyka komunii w miłości warunkują się wzajemnie w życiu Kościoła. Dopiero po Ockhamie i po reformacji herezja została zdefiniowana przede wszystkim z punktu widzenia noetycznego, jako doktryna, która przeciwstawia się bezpośrednio i na zasadzie przeciwieństwa prawdzie objawionej przez Boga i autentycznie podawanej przez Kościół.

Ta mocno zobiektywizowana definicja herezji, nawet jeśli nie uwypukla elementu praktycznego postawy podmiotowej wierzącego, utrzymuje jednak istotne odniesienie do Kościoła wierzącego, który w swoim akcie nauczycielskim podaje do wierzenia określoną doktrynę jako objawioną. W każdym razie zostają w ten sposób uwypuklone aspekty "praktyczne” "prawej wiary” i błędu w prawdzie.

\subsection{ORTODOKSJA JAKO POSTAWA}

„Prawa wiara” i herezja nie tylko charakteryzują się poprawnością lub błędem w wypowiedzi wiary wziętej jako taka obiektywnie, ale także postawą praktyczną tego, kto uznaje takie stwierdzenie, przez co zasadnie można powiedzieć za Piusem IX: „Ta sama wypowiedź jest katolicka na ustach katolika i heretycka na ustach heretyka".

Aby zdać sobie sprawę z ważności tego stwierdzenia, trzeba uwzględnić sposób, w jaki dochodzi się do herezji, a to z kolei pokazuje nam - na zasadzie przeciwieństwa - w jaki sposób trwa się w ortodoksji. Jeśli jest prawdą - jak zauważył Newman - że herezja wynika z przyjęcia elementu prawdziwego, ale wyizolowanego z całości innych prawd i opisanego w sposób jednostronny, to ortodoksja jest definiowana jako postawa przylgnięcia do całości wydarzenia Prawdy objawionej, źródła wszystkich wypowiedzi zarówno kerygmatycznych, jak i doktrynalnych ${ }^{16}$. To przylgnięcie do całości Prawdy objawionej może jednak mieć miejsce tylko w komunii Kościoła, w którym jest obecna Prawda - wydarzenie w swojej całości. Oznacza to równocześnie, że nie można mieć prawej wiary poza i ponad aktualnym świadectwem Kościoła, który wyraża

16 Por. J. H. Newman, O rozwoju doktryny chrześcijańskiej, tłum. J. W. Zielińska, Warszawa 1957, s. 40. 
ją w swoim języku, i że ortodoksja nie może być zredukowana do uznania za prawdziwe samych dogmatów. Oznaczałoby to zredukowanie wiary do kwestii intelektualnej, podczas gdy wiara obejmuje całego człowieka, zarówno w wymiarze indywidualnym, jak i społecznym jego egzystencji.

\subsection{ORTODOKSJA I WSPÓLNOTA KOŚCIOŁA}

Powyższe stwierdzenia prowadzą do sformułowania ważnego kryterium hermeneutycznego, które łączy w sposób nierozdzielny epistemologię wiary w jej stwierdzeniach dogmatycznych, a więc ortodoksją w wierze, z przylgnięciem "praktycznym” do wspólnoty Kościoła jako miejsca teologicznego, w którym dokonuje się formułowanie, a następuje zrozumienie formuł noetycznych. Można więc powiedzieć, że teologia wyizolowana ze wspólnoty jest błędna z definicji. Przylgnięcie do wspólnoty eklezjalnej nie konstytuuje się jednak tylko na mocy przylgnięcia intelektualnego do formuł słownych jej doktryny, ale raczej poprzez przylgnięcie praktyczne do wydarzenia Słowa w niej żyjącego. Chrześcijaństwo pierwotne pokazuje nam bardzo jasno, jak „prawa wiara” (ortodoksja) i „prawa praktyka" (ortopraksja) były nierozerwalnie złączone ze sobą. Na początku kryteria ocen odnośnie do komunii Kościoła nie były ani po prostu doktrynalne, ani po prostu dyscyplinarne. Stawiano na pierwszym miejscu jedność symboliczną, która urzeczywistniała się we wspólnocie wiary jako zasadzie wspólnego życia i działania. Zakładało to prawą praktykę w prawdzie, miłości i sprawiedliwości. Nie mógł więc - na przykład - być uważany za pozostającego w komunii Kościoła i prawdy ten, kto prześladował ubogiego.

Wewnętrzne powiązanie między praktyką Kościoła i jego stwierdzeniami doktrynalnymi uwidacznia się także w wielu wątkach rozwoju dogmatycznego. Została już przekroczona koncepcja, według której rozwój dogmatu byłby wynikiem postępu logiki formalnej zastosowanej do pewnych stwierdzeń doktrynalnych, które były powtarzane i wyjaśniane. Zanim będzie systemem wypowiedzi które do niego niewątpliwie należą - objawienie jest Słowem-rzeczywistością. Kościół nie tylko ma do dyspozycji język mówiony 
i pojęcia, aby nawiązać kontakt $\mathrm{z}$ tą rzeczywistością, ale także ma praktykę swojego życia wiary i miłości, jak również swoje życie kultyczno-sakramentalne, które niesie w sobie wewnętrzną treść doktrynalną, przynajmniej pośrednio. Trafnie ujmuje to zagadnienie konstytucja Dei Verbum II Soboru Watykańskiego, gdy stwierdza: „Kościół w swojej doktrynie, w życiu i kulcie przedłuża i przekazuje wszystkim pokoleniom wszystko, czym jest i w co wierzy" (nr 8).

Samo życie chrześcijańskie jest więc nasycone poznaniem mądrościowym, które przekazuje dogmat. Kościół jest pierwotnym i podstawowym miejscem prawdy chrześcijańskiej - podmiotem, w którym objawienie jest otrzymywane i zachowywane w sposób nienaruszony, nie w sensie czysto biernym, ale poprzez jego pogłębianie i jego aktualizację w konkretnym życiu. Kościół nigdy nie uznał za doktrynę wiary niczego poza tym, co już wyznawał jako przedmiot swojej wiary. Ten fakt znajduje szczególne odzwierciedlenie w modlitwie liturgicznej. Zostało już wielokrotnie wykazane, że w Kościele starożytnym dogmatem mogło być tylko to, co mogło być liturgią, czego wyrazem stało się skodyfikowanie pryncypium: lex orandi - lex credendi $i^{17}$. Oznacza ono, że teologia otrzymuje od liturgii swój impuls witalny, a liturgia - ze swej strony - służy celebracji tajemnicy. W liturgii rozbrzmiewa więc słowo, a następnie to słowo staje się hymnos. Liturgia jest więc dogmatem, który przyjął postać modlitwy, a teologia, która stara się go zrozumieć, jest doksologią ${ }^{18}$.Zanim dojdzie się do świadomego, jasnego i określonego wyrażenia prawdy wiary, Kościół już nosi tę prawdę, choć jeszcze nie została ona ujęta w konkretnej formule, w swoim życiu i rzeczywiście nią żyje. To poprzez praktykę swojego życia, do którego należą sformułowania wiary, kształtuje on

17 Por. A. Dulles, El oficio de la teología. Del símbolo al sistema, Barcelona 2003, s. 217-230.

18 Ten aspekt dogmatu i teologii jest szczególnie podkreślany przez teologów należących do tradycji wschodniej. Por. D. Staniloaë, Il genio dell'Ortodossia, Milano 1986, s. 110-125; S. Bułgakow, Prawosławie. Zarys nauki Kościota prawosławnego, tłum. H. Paprocki, Białystok-Warszawa 1992, s. 115-125. Por. także G. Wainwright, Doxology. The praise of God in worship, doctrine and life, New York 1980. 
najbardziej bezpośrednio i nieustannie spotkanie z wydarzeniem Jezusa Chrystusa - Prawdą osobową, która stale jest przekazywana w akcie żywej Tradycji. Z tego powodu św. Tomasz stwierdzał, że praxis Ecclesiae, kierowana przez Ducha Świętego, stanowi kryterium sądu o prawdzie ${ }^{19}$.

\section{PROPOZYCJE}

Z powyższych refleksji wyłania się kilka zasadniczych propozycji pod adresem współczesnej teologii, jeśli chce - a powinna zachować równowagę między ortodoksją i ortopraksją, to znaczy z jednej strony przylgnać do prawdy, a z drugiej - kształtować konkretne życie zarówno Kościoła, jak i poszczególnych wierzących. Teologii przez długi czas udawało się spełniać ten trudny postulat, dzięki czemu prawda pozostawała czymś żywym w Kościele, a życie w sposób naturalny szukało prawdy. Wobec dzisiejszego rozziewu tych dwóch aspektów życia Kościoła, odbijającego się niekorzystnie zarówno na teorii, jak i praktyce, warto sięgnąć do doświadczeń Kościoła w tym względzie. Szczególne znaczenie posiada w tym względzie doświadczenie Kościoła pierwotnego.

a. Aby więc mogła postępować synteza ortodoksji i ortopraksji, teologia powinna starać się bardziej zakorzenić w konkretnym życiu Kościoła. Postulat ten łączy się ze zwróceniem uwagi na samą naturę teologii jako nauki kościelnej - jako taka ma ona stale brać pod uwagę Kościół nie tylko w aspekcie jego wypowiedzi doktrynalnych, ale także w aspekcie jego wewnętrznego życia. Życie Kościoła jest miejscem, do którego powinien zejść teolog, aby odkryć w nim żywą tkankę wiary oraz aktualne problemy, z którymi wiara musi się zmagać w swoim życiu i w swoim rozwoju. Takie podejście pozwoli teologii zbliżyć się do życia oraz włączyć się w jego interpretację i rozwój. Poza tym, ponieważ życie Kościoła nie jest nieomylne w swoich przejawach, teolog powinien podjąć się interpretacji różnych aspektów tego życia, by przyczyniać się do jego oczyszczenia,

19 Por. Tomasz z Akwinu, Summa theologiae II-II q. 10 a. 12; III q. 66 a. 10. 
a jeśli trzeba także do wyeliminowania niektórych z tych form, jeśli są błędne.

b. Na gruncie tego zbliżenia się do życia Kościoła wyłania się także funkcja pośrednicząca teologii, na którą tak wielką uwagę zwracał papież Paweł VI w swoich wypowiedziach na temat teologii kierowanych do teologów ${ }^{20}$. Otóż ta funkcja pośrednicząca ma swoje odniesienie najpierw do Urzędu Nauczycielskiego Kościoła. Zadaniem teologa jest informowanie tego urzędu na temat tego, czym żyje Lud Boży, by w ten sposób pogłębiała się wiedza, jaką na temat jego życia mają pasterze, na gruncie której mogą rozwijać swoje przepowiadanie i działania duszpasterskie. $Z$ drugiej strony, zadaniem teologa jest spełnianie funkcji pośredniczącej między pasterzami i wiernymi, a mianowicie - przez wyjaśnianie i przekazywanie tego, czego naucza Urząd Nauczycielski, oraz przez dowartościowanie pytań, które zadają wierni. Między tymi dwoma jakby biegunami sytuuje się pozycja teologa; podjęcie wymagań, jakie stają przed nim zarówno z jednej, jak i z drugiej strony, ma konkretny związek z tym, w co wierzy i czym żyje cały Kościól. Ponieważ zostaje w takim ujęciu objęte całe życie Kościoła, w aspekcie zarówno teorii, jak i praktyki, dlatego też ma ono wpływ na dokonanie ich syntezy.

c. Teologia staje się nauką syntetyzującą ortodoksję i ortopraksję, jeśli uwzględnia to zadanie, które wyznaczył jej papież Jan XXIII i które przypominają kolejni papieże, a mianowicie - odczytywanie z naków czasu u ${ }^{21}$. Znaki czasu są konkretnymi wyzwaniami, nie tylko o charakterze wewnątrzkościelnym, które skłaniają teologię do zadawania pytań o ich naturę i o ich logos. Zawiera się więc w nich potrzeba zinterpretowania ich w świetle prawdy chrześcijańskiej.

20 Synteza tej problematyki została przedstawiona w dokumencie Międzynarodowej Komisji Teologicznej Urzad Nauczycielski Kościoła i teologia (1976), [w:] Od wiary do teologii. Dokumenty Międzynarodowej Komisji Teologicznej 1969-1996, red. J. Królikowski, Kraków 2000, s. 55-69.

21 Por. I. Korzeniowski, I segni dei tempi nel pensiero di Giovanni Paolo II, Roma 1997; S. Bielecki, Teologia znaków czasu, Kielce 2006; Teologia znaków czasu. Dogmatycy wobec polskiego „dziš” Kościoła, red. K. Góźdź, K. Michalczak, Poznań 2008. 
Z drugiej zaś strony znaki czasu są rzeczywistościami egzystencjalnymi, które trzeba uwzględnić w praktyce kościelnej, ale by mogły zostać faktycznie w niej uwzględnione, zachodzi potrzeba sformułowania sposobów tego uwzględnienia. Oznacza to pilną potrzebę żywego łączenia teorii i praktyki, gdyż tylko w takim przypadku podjęcie znaków czasu będzie rzeczywiste i owocne.

d. Nie bez znaczenia dla nowej syntezy teorii i praktyki w teologii pozostają formułowane pod jej adresem postulaty bliższego zajęcia się kwestiami związanymi wprost z życiem Kościoła, w jego aspektach najsubtelniejszych i najbardziej duchowych, jak na przykład: wiara, świadectwo, świętość, doświadczenie duchowe i mistyczne, życie wspólnot i świętych jako locus theologicus itd. Analiza tych praktycznych rzeczywistości może, z jednej strony, służyć ich pogłębieniu, którego niewątpliwie dzisiaj potrzeba, gdyż często teologia systematyczna poświęca im niewiele uwagi, a z drugiej może przyczynić się do zaangażowania się teologów w bardziej bezpośrednie - z praktycznego punktu widzenia - kształtowanie tych rzeczywistości eklezjalnych. 


\section{ROZDZIAE IX}

\section{米 \\ Ojcowie Kościoła i teologia}

Ojcowie Kościoła są żywi i ciągle do nas przemawiają żywym głosem poprzez swoje pisma. $Z$ tej racji obcowanie $\mathrm{z}$ ich utworami jest niezbędne i niczym niezastąpione.

ks. Franciszek Drączkowski ${ }^{1}$

W teologii współczesnej w odniesieniu do ojców Kościoła daje się zauważyć żywo pulsujące napięcie. $Z$ jednej więc strony studiowano i nadal studiuje się ojców Kościoła z intencją odnowienia teologii katolickiej poprzez powrót do źródeł (ressourcement), najpierw w polemice z teologią neoscholastyczną, a dzisiaj w polemice z teologiami zbyt filozoficznymi i abstrakcyjnymi. Do najbardziej reprezentatywnych przedstawicieli tego kierunku, którzy stali się równocześnie twórcami programu neopatrystycznego w teologii katolickiej, należą: Odo Casel, Hugo Rahner, Henri de Lubac, Jean Daniélou. Z drugiej jednak strony po II soborze watykańskim wszedł żywo do teologii program określany ogólnie jako aggiornamento, czyli najogólniej mówiąc „przystosowanie”, z którym jest związane pewne dystansowanie się w stosunku do przeszłości i minionej

1 F. Drączkowski, Patrologia, Pelplin-Lublin 1998, s. 6. 
tradycji teologicznej, a więc także w stosunku do epoki patrystycznej, z tą intencją, by zrobić więcej miejsca dla bezpośredniej relacji między objawieniem Bożym i obecną chwilą historyczną, czyli uprzywilejować Pismo Święte, czyniąc je „duszą teologii”. Wydaje się jednak, że nawet mając na względzie ten drugi problem i jego oczywiste znaczenie w dynamicznie zmieniającym się kontekście kulturowym i cywilizacyjnym, nigdy nie należy rezygnować z powrotu do źródeł i jego kontynuowania, gdyż wielokrotnie właśnie taki powrót stawał się okazją i inspiracją dla twórczych reform. Warto zauważyć, że na II soborze watykańskim najbardziej wpływową rolę odegrali teologowie, którzy opierali program odnowy Kościoła na powrocie do najbardziej autentycznej Tradycji Kościoła ${ }^{2}$. To napięcie stanowi ważne wyzwanie między innymi dla nauczania teologii patrystycznej i do włączenia jej do różnych dziedzin teologicznych.

Zarysowane napięcie domaga się interpretacji teologicznej. Aby nie trzeba było go interpretować w taki sposób, że dokona się likwidacji któregoś z jego biegunów, trzeba przede wszystkim wyjaśnić i rozwinąć relację, jaka - z jednej strony - zachodzi między ojcami Kościoła i Pismem Świętym, a z drugiej strony między ojcami i Tradycją Kościoła. W szczególności chodzi o to, by rozstrzygnąć, czy ojcowie Kościoła stanowią jakąś przeszkodę dla rozumienia Pisma Świętego, czy też są dla niego zasadniczym kluczem interpretacyjnym oraz czy należą oni do Tradycji Kościoła w taki sam sposób, jak inne epoki teologii, czy też mają w niej jakąś własną odrębność. Tylko podając spójne i możliwie rozstrzygające rozwiązanie tych dwóch kwestii, będzie można także określić, czy i w jaki sposób mogą nadal być ważnym, a nawet nieodzownym punktem odniesienia dla teologii współczesnej. Chodzi więc o wyjaśnienie tego, co stwierdza konstytucja soborowa o objawieniu Bożym Dei Verbum, idąc po linii wcześniejszej Tradycji Kościoła (por. nr 8, 12, 23). Chodzi ponadto o przekroczenie rozpowszechnionej interpretacji

2 Por. K. H. Neufeld, Vescovi e teologi al servizio del Concilio Vaticano II, [w:] Vaticano II: bilancio e prospettive. Venticinque anni dopo (1962-1987), a cura di R. Latourelle, t. 1, Assisi 1988², s. 83-109. Autor omawia znaczenie teologii wypracowanej przez H. de Lubaca w ramach II Soboru Watykańskiego. 
historycznej, która w ojcach Kościoła widzi świadków odległej przeszłości, których należy studiować, ale tylko przy pomocy metod historycznych. Chodzi o pokazanie, że - jak stwierdza Georges Florovsky, czołowy przedstawiciel prawosławnej teologii neopatrystycznej - „świadectwo Ojców zawiera coś więcej niż charakter historyczny. Świadectwo Ojców należy w sensie właściwym i całkowitym do samej syntezy wiary ortodoksyjnej"3. Podjęcie i wyjaśnienie tej kwestii ma także znaczący wymiar ekumeniczny, który ma do odegrania poważną rolę w relacjach z Kościołami chrześcijańskiego Wschodu, które chętnie definiują się jako „Kościoły ojców”4.

\section{OJCOWIE KOŚCIOŁA W TEOLOGII KATOLICKIEJ}

W świetle tradycyjnej teologii katolickiej możemy powiedzieć, że jak Nowy Testament nie przeciwstawia się Staremu, ale mają się one do siebie tak, jak duch do litery, czyli stanowią wewnętrznie opartą jedność, tak zwrócenie się do ojców Kościoła nie oznacza w teologii powrotu do Prawa wbrew Pismu Świętemu rozumianemu jako łaska, ale to właśnie oni są tymi, którzy pierwszorzędnie przyczynili się do wydobycia i ukazania Ducha Bożego, kryjącego się pod literą Pisma. Rola ojców Kościoła w teologii współczesnej wynika więc przede wszystkim z tego wkładu, jaki mogą wnieść do rozwiązania żywotnego dla wiary problemu interpretacji słowa Bożego, to znaczy ukazania relacji zachodzących między lekturą historyczno-cielesną i lekturą aktualizująco-duchową Biblii ${ }^{5}$.

3 G. Florovsky, Grégoire Palamas et la patristique, „Istina” 8 (1961-1962), s. 116.

4 Por. B. Petrà, La Chiesa dei Padri. Breve introduzione all'Ortodossia, Bologna 1998, s. 23-32.

5 Por. Y. Congar, Les saints Pères, organs privilégiés de la Tradition, „Irenikon” 35 (1962), s. 479-498; J. Ratzinger, Die Bedeutung der Väter für die gegenwärtige Theologie, „Theologische Quartalschrift” 148 (1968), s. 257-282 (tł. polskie w: J. Ratzinger, Formalne zasady chrześcijaństwa. Szkice do teologii fundamentalnej, tłum. W. Szymona, Poznań 2009, s. 178-203); A. Orbe, Lo studio dei Padri della Chiesa nella formazione sacerdotale, [w:] Vaticano II: bilancio e prospettive, t. 2, s. 1366-1380. Por. także W. Löser, Im Geiste des Origenes. Hans Urs von Balthasar als Interpret der Theologie der Kirchenväter, Frankfurt 1976; Ch. Kannengieser, Alla scuola dei Padri. Balthasar alle prese con 
Jak zatem można ściślej określić tę ich rolę? Trzeba najpierw powiedzieć, że na ojców Kościoła można spojrzeć w dwojaki sposób - sposób historyczny i sposób dogmatyczny. Historyk ma przede wszystkim zadanie wszechstronnego i krytycznego badania różnych tekstów, wnikając poprawnie w ich sens dosłowny jako ich sens podstawowy - podobnie jak ma to miejsce w przypadku sensu dosłownego Pisma Świętego. Historyk ma doprowadzić do swoistego „rozróżnienia” tekstów. Natomiast na dogmatyku spoczywa zadanie określenia - ponad literą - gdzie sytuuje się jedność tych tekstów, a gdzie jej brakuje, w czym łączą się one ze sobą, a w czym tej łączności brakuje. Wyniki, do których dochodzi się w ramach historii i dogmatyki, mogą różnić się między sobą, ale w ramach wiary i życia Kościoła można rozwiązać problem pewnej „alternatywności" zachodzącej między egzegezą historyczną i egzegezą dogmatyczną, czy też - mówiąc bardziej ogólnie - między egzegezą biblijną i dogmatykąa .

Ta alternatywność budzi wiele niepokoju, a nawet sporów w teologii współczesnej, dlatego trzeba na nią zawsze zwracać uwagę. Ojcowie, którzy podchodzili do tekstu biblijnego bez tego dylematu, powinni więc być w stanie udzielić pomocy teologii współczesnej w przezwyciężeniu tego dylematu. Oczywiście w dzisiejszej sytuacji metodologicznej, szukając jedności egzegezy i dogmatyki, historii i aktualności, nie można uniknąć przejścia przez fazę ich rozróżnienia metodologicznego. Jest więc konieczne, aby zarówno historyk, jak i dogmatyk uwzględnił ojców jako świadków, mających swoje historyczne usytuowanie; z drugiej jednak strony trzeba uznać, że jak nie jest aż tak bardzo trudno, także na drodze historycznej,

la teologia patristica, [w:] Hans Urs von Balthasar. Figura e opera, a cura di K. Lehman, W. Kasper, Casale Monferrato 1991, s. 109-117.

6 Na temat istoty tego problemu pisze papież Benedykt XVI w przedmowie do swojej książki o Jezusie z Nazaretu. Por. Benedykt XVI, Jezus z Nazaretu, t. 1: Od chrztu w Jordanie do Przemienienia, tłum. W. Szymona, Kraków 2007, s. 5-15. Szerzej na ten temat w: A. Dulles, El oficio de la teología. Del símbolo al sistema, Barcelona 2003, s. 231-245. Systematyczne ujęcie zagadnienia w: R. Guardini, Pismo Święte i nauka wiary. Poznanie duchowe, które otrzymuje się $w$ darze, tłum. K. Czuba, Kielce 2002. 
dojść do zobaczenia jedności Pisma Świętego ${ }^{7}$, tak nie jest niemożliwe zrozumieć dogmatycznie, na czym polega unanimis consensus patrum w doktrynie chrześcijańskiej i jak dzisiaj ten consensus może stać się normatywny dla teologii, ponieważ takie zadanie wyznaczają mu wskazania formułowane w nauczaniu Kościoła ${ }^{8}$.

Praktycznych przykładów, które mogą pokazać sposób rozumienia tej kwestii, jest wiele. Właściwie analiza rozwoju każdej z wielkich kwestii doktrynalnych mogłaby posłużyć za przykład. Gdy weźmiemy więc pod uwagę jakieś zagadnienie i jego opracowanie pojęciowe, przy pomocy którego je wyrażono, to pierwszą dostrzeganą rzeczą jest zróżnicowanie stanowisk w danej kwestii prezentowane przez ojców Kościoła. Większe bądź mniejsze różnice, jakie zaznaczają się między poszczególnymi stanowiskami, raz są wyrazem uprawnionego pluralizmu, innym razem wskazują na ujęcia niewystarczające, a także zawierają ujęcia obiektywnie błędne. Nigdy nie sprzyjało i nie sprzyja wierze ignorowanie i ukrywanie błędów, jakie pojawiły się w przeszłości, ponieważ to nie przeszłość sama w sobie ma wartość, ale jej wkład w poszukiwanie prawdy, która nie da się zamknąć w żadnym dążeniu historycznym zmierzającym do jej wyrażenia. Miał rację św. Cyprian, gdy stwierdzał: „Nam antiquitas sine veritate vetustas erroris est" ${ }^{\prime \prime}$. Tym, co służy wierze, jest dążenie do określenia i wydobycia tej autentycznej i jednorodnej linii rozwoju doktrynalnego, które nie tyle wyraża się w literze rozmaitych wypowiedzi, ale raczej w ich duchu. Można go odkryć nawet tam, gdzie są zajmowane nawet skrajnie przeciwne stanowiska, jeśli są wyprowadzane z tych samych przesłanek.

Pytanie dotyczące aktualności ojców stawia nas więc wobec potrzeby nowego spojrzenia na dwa światy - świat wiary i świat nauki, w perspektywie, która widzi ich fundamentalną jedność. Trzeba oczywiście

7 Jeśli chodzi o kwestie dotyczące jedności Pisma Świętego, zwłaszcza Nowego Testamentu, por. J. N. Aletti, Jésus-Christ fait-il l'unité du Nouveau Testament?, Paris 1994.

8 Por. Pius XII, enc. Divino afflante Spiritu: DS 3831.

9 Cyprian, Epistula 74, 9. Tłumaczenie polskie: Cyprian, Listy, tłum. W. Szołdrski, Warszawa 1969, s. 279: „Albowiem zwyczaj bez prawdy jest zastarzałym błędem". 
zaznaczyć, że w tym wypadku mamy do czynienia z nową wersją dysputy scholastycznej na temat relacji między auctoritas i ratio ${ }^{10}$. Pojednawcze zadanie współczesnego historyka polega więc na wolnym od przesądów wydobyciu w równej mierze zarówno heterodoksji, jak i ortodoksji rozmaitych wypowiedzi, ale przy podstawowym założeniu i świadomości, że właśnie wtedy, gdy odkrywa się różne braki, będące wynikiem zagubienia sensus fidei Kościoła i zerwania więzi ze wspólnotą eklezjalną, korzysta na tym prawda, gdyż bardzo konkretnie widzi się wtedy, które ujęcia prowadzą do błędów. W tym miejscu widać więc, że to nieprzejednany konserwatyzm prowadzi do podziału Kościoła i do zaciemnienia jego nauczania. Tylko ten, kto dokonuje inteligentnie i krytycznie nowych interpretacji, jest tym, który najlepiej przyczynia się do jedności i wzrostu Kościoła.

Nawiązując do kwestii interpretacji Pisma Świętego, trzeba powiedzieć, że nowożytna egzegeza biblijna dogłębnie odczuła na sobie pojawienie się ahistorycznego rozumienia, jakie nadano w okresie oświecenia nauce i technice, dla których nie ma znaczenia proces historyczny, poprzez który dochodzi się do osiągnięcia poznania, które zostaje następnie zastosowane praktycznie. I tak historia odkrycia fal elektromagnetycznych nie ma najmniejszego znaczenia dla ich zastosowania praktycznego. Jeśli chodzi natomiast o nauki humanistyczne, to historia każdej z nich w większym bądź mniejszym stopniu określa jej istotę. W autentycznej filozofii zawsze będzie obowiązywała znajomość Platona i Arystotelesa. Z tego samego powodu interpretacja Pisma Świętego wypracowana przez ojców Kościoła nie może być traktowana jako pozbawiona znaczenia w aktualnej teologii i egzegezie. Mimo uprawiania egzegezy - niejako jeszcze przedkrytycznej - ojcowie Kościoła są świadkami Tradycji właśnie w tym sensie, że ich interpretacja Biblii jest naznaczona autorytetem, który przekracza ramy samej filologii. W tym sensie na przykład komentarz Orygenesa do Ewangelii św. Jana będzie zawsze kluczowym tekstem dla egzegety i teologa zmagającego się z tym tekstem. W kierunku takiego ujęcia idzie podwójne kryterium sformułowane

10 Por. M. D. Chenu, La théologie au douzième siècle, Paris 1957, s. 353-357. 
przez Sobór Trydencki i I Sobór Watykański, które - z jednej strony - stwierdzają trwałe znaczenie Tradycji dla procesu rozumienia i wyjaśnienia Pisma Świętego, a z drugiej wskazują na ojców, będących świadkami Tradycji, jako na interpretatorów Biblii ${ }^{11}$.

W tym kontekście pojawia się kwestia dotycząca tego, w jakiej mierze i w jakim znaczeniu ojcowie Kościoła są świadkami Tradycji rozumianej jako zjawisko pneumatologiczne - która autentycznie interpretuje Pismo Święte. Czy zatem ojcowie i Tradycja są tym samym? Pewna część współczesnych teologów katolickich, sytuując się w przejściu od ressourcement do aggiornamento, popełniła błąd polegający na utożsamieniu pojęć Tradycji i teologii patrystycznej, co przyniosło szkodę zwłaszcza tej ostatniej. Wydaje się, że na przykład dla Josefa Ruperta Geiselmanna Tradycja nie jest niczym innym, jak tylko żywą obecnością Pisma Świętego w Kościele, w niczym nie różniąc się jakościowo od teologii patrystycznej i ograniczając się do wyrażania go w aktualnym życiu Kościoła ${ }^{12}$. Podobne ujęcia są obecne w teologii prawosławnej. Takie jednak ujęcie oznacza, że Tradycja z jednej strony utożsamia się z Pismem Świętym, a z drugiej jest ona taka sama jakościowo w każdym czasie. Oznacza to, że analizowanie przeszłości jest po prostu nieużyteczne, gdyż wystarczy odnieść się za każdym razem wyłącznie do Pisma Świętego, które samo w sobie jest w pełni „wystarczające”"13.

11 W konstytucji dogmatycznej Dei Filius I Soboru Watykańskiego czytamy: „W sprawach wiary i moralności, należących do gmachu nauki chrześcijańskiej, za prawdziwy sens Pisma Świętego należy przyjmować taki, jaki utrzymywała i utrzymuje święta Matka Kościół, do której należy osądzanie o prawdziwym sensie i wyjaśnianiu świętych pism. Nikomu zatem nie wolno wyjaśniać Pisma Świętego przeciw temu sensowi albo też przeciw jednomyślnej zgodzie ojców" (Dokumenty Soborów Powszechnych: tekst taciński i polski, t. 4: (1511-1870): Lateran V, Trydent, Watykan I, układ i oprac. A. Baron, H. Pietras, Kraków 2004, s. 897).

12 Por. J. R. Geiselmann, Das Konzil von Trient über das Verhältnis der Hl. Schrift und der nich geschriebenen Traditionen, [w:] Die mündliche Überlieferung, hrsg. von M. Schmaus, München 1957, s. 123-206, tutaj s. 184-193.

13 Por. P. O'Callaghan, Sola Scriptura o tota Scriptura? Una riflessione sul principio formale della teologia protestante, [w:] La Sacra Scrittura anima della teologia, a cura di M. Tábet, Città del Vaticano 1999, s. 147-168. 
Inną konsekwencją tej koncepcji jest to, że z jednej strony przeszłość pomaga tylko w bardziej wewnętrznym zrozumieniu świadectwa biblijnego, a z drugiej - że teologia patrystyczna nie ma innego znaczenia niż teologia w każdej innej epoce Kościoła. Zatem weryfikuje się w tym przypadku podwójna redukcja - redukcja Tradycji do Pisma Świętego oraz redukcja ojców do ogólnej tradycji teologicznej. Nie można zaakceptować żadnej z tych redukcji ze względu na ich jednostronność, ale trzeba przyznać ojcom takie miejsce, jakie należy się im jako niezastąpionym i nieprzekraczalnym nauczycielom jedności Pisma Świętego, wiary i Kościoła.

Na redukcyjne podejście do ojców Kościoła ma wpływ pojawianie się także innych propozycji teologicznych. W teologii katolickiej po ogłoszeniu dogmatów maryjnych w 1854 i w 1950 roku oraz w bezpośrednim związku z nimi, pojawiła się propozycja, według której brak świadectw biblijnych i historycznych w danej kwestii może zostać zastąpiony pogłębieniem systematyczno-spekulatywnym. Jakaś doktryna, by mogła zostać uznana za prawdziwą, nie potrzebuje należeć od samego początku do dziedzictwa wiary Kościoła, ale wystarcza, by wyłoniła się w pewnym momencie jego historii i została uznana $w$ jego świadomości za objawioną i przyjęta jako taka. W takim ujęciu mamy do czynienia $\mathrm{z}$ ahistorycznym rozumieniem Tradycji, które prowadzi do pomniejszenia znaczenia ojców, a nawet do zrezygnowania $\mathrm{z}$ nich zarówno w egzegezie, jak i w dogmatyce, gdyż ich świadectwo zostaje pozbawione znaczenia normatywnego.

Wyżej opisane redukcje, pierwsza związana z historyzmem, a druga $\mathrm{z}$ fideizmem, jakie pojawiły się w środowisku katolickim, powinny zostać przezwyciężone przez odwołanie się do dwóch możliwości-zadań teologii. Chodzi mianowicie o możliwość-zadanie nadania teologii nośności historycznej, broniąc ją zarazem przed ahistorycznym sposobem postępowania, jak czynią nauki przyrodnicze, jak również przed czystym historyzmem, który rozbija jedność wiary. Druga możliwość-zadanie dotyczy aktualizowania teologii ojców mimo ich uwarunkowań i ograniczeń historycznych. Innymi słowy, jeśli nie zaangażuje się teologii ojców na tych dwóch frontach, to w sposób nieunikniony utracą swoją uprzywilejowaną 
pozycję jako szczególni interpretatorzy Pisma Świętego i autorytatywni świadkowie Tradycji, a ściślej mówiąc jako świadkowie i interpretatorzy Pisma Świętego w niepodzielonym Kościele pierwotnym, a więc także jako nauczyciele ekumenizmu. $Z$ tego natomiast punktu widzenia stanowią oni wielką pomoc, ponieważ są, oczywiście, teologami katolickimi, ale nie tylko rzymskokatolickimi. Z tego powodu stanowią także ważny punkt odniesienia dla prawosławia i dla protestantyzmu, chociaż $\mathrm{w}$ obydwu przypadkach problem ojców staje w inny sposób.

\section{OJCOWIE KOŚCIOŁA I EKUMENIZM}

Kwestia miejsca ojców Kościoła w ramach ekumenizmu jest problematyczna, zwłaszcza w relacji z protestantyzmem. Podczas gdy teologia wschodnia chce być przede wszystkim teologią patrystyczną, to teologia reformowana zajmuje w tej kwestii stanowiska przeciwstawne. Melanchton i Kalwin starali się wykazać, że reformacja była zgodna z duchem ojców Kościoła, a tym samym przeciwna teologii średniowiecznej, którą mocno atakowali. Natomiast Luter stał na stanowisku, że zepsucie doktryny zaczęło się szybko już u ojców, tak że ich studiowanie uznał za stratę czasu. Lekceważył ponadto ojców z powodu stosowania metody alegorycznej w egzegezie, która jego zdaniem przyczyniała się do zaciemniania prawdziwego sensu Pisma Świętego.

W protestantyzmie współczesnym widzimy raczej rozpowszechnienie się stanowiska pośredniego, które stara się - idąc po linii Melanchtona - uwypuklić znaczenie ojców. W tym przedsięwzięciu nie idzie się jednak po linii dowartościowania ich eklezjalności, ale na ogół sytuuje się na gruncie egzegezy, widząc w nich interpretatorów Pisma Świętego. To ujęcie jest jednak dalece niewystarczające, ponieważ bardzo zawęża teologiczną pozycję ojców. W tej sytuacji trzeba więc jasno odpowiedzieć na pytanie, czy ułatwiają oni, czy utrudniają dostęp do Pisma Świętego. Z katolickiego punktu widzenia chodzi o udzielenie takiej odpowiedzi, która pozwoli uznać, że ojcowie tak interpretowali Pismo Święte, że nie oddalali się przy tym od jego prarozumienia eklezjalnego, w wyniku czego rozdzielanie 
dwóch aspektów byłoby postępowaniem niezgadzającym się z ich globalną postawą duchową. Obecny protestantyzm w swojej złożoności właśnie dlatego, że nie uznaje eklezjalności ojców, niemającej znamienia rzymskokatolickiego, które rozwinęło się w następnych epokach na Zachodzie, nie wydaje się sprzyjać systematycznemu zbliżeniu do pryncypium Kościoła katolickiego.

Ojcowie Kościoła nie wydają się więc odgrywać większej roli w ekumenizmie zachodnim i ich faktyczne wykorzystanie na obecnym etapie ekumenizmu jest bardzo nikłe. Nie przeszkadza to jednak w tym, by Kościół katolicki, usiłując stać się bardziej ekumeniczny od wewnątrz, to znaczy w swojej duchowości ekumenicznej, rozwijał swoją komunię z ojcami, by stawać się bardziej katolickim, a tym samym bardziej uzdolnionym do ekumenizmu. Będzie to droga prowadząca do szerszego otwierania się na ekumenizm z Kościołami prawosławnymi, który ma znaczący wymiar patrystyczny i który musi ciągle zmierzać do pogłębienia, jeśli ma się przyczynić do rzeczywistego zjednoczenia Kościołów.

Po tym, co zostało do tej pory powiedziane, trzeba przejść do pozytywnego wyjaśnienia i określenia, kim są ojcowie dla Kościoła katolickiego. Takie określenie jest nieodzowne z punktu widzenia ekumenicznego, ponieważ w decydującym stopniu pokazuje, na czym polega jedność Kościoła i jakie może być znaczenie ojców w poszukiwaniu przyszłej jedności. Chodzi więc o odpowiedź na pytanie, kto z katolickiego punktu widzenia jest uznawany za „ojca Kościoła”. W tym momencie jest już jasne, że ojcowie są autentycznymi i autorytatywnymi interpretatorami Pisma Świętego, nie tyle jako filolodzy, ale dlatego i w takiej mierze, w jakiej wyrazili wiarę Kościoła w sposób jakościowo determinujący dla jego następnego rozwoju historycznego, czyli chodzi o uzasadnienie, że są także kimś „więcej”. Takie stwierdzenie domaga się jednak dalszego sprecyzowania.

\section{POJĘCIE OJCÓW KOŚCIOŁA I ICH AUTORYTET}

Aby odpowiedzieć na pytanie, kim są ojcowie Kościoła, trzeba przede wszystkim ocenić to, co w Kościele i w teologii dokonało się 
w ciągu wieków dzielących epokę patrystyczną od epoki obecnej, oraz zauważyć realistycznie, że od jakiegoś czasu także dla Kościoła katolickiego ojcowie są ojcami tylko pośrednio, ponieważ można powiedzieć, że tych ojców poniekąd przybyło. Mówi się więc już dzisiaj o „średniowiecznych ojcach Kościoła”, co ma uzasadnienie o tyle, że aktualnie Kościół i teologia są w znacznym stopniu ukształtowane właśnie przez nich. W taki sam sposób także teologia ewangelicka ma swoich „ojców” - od Lutra po liberalnych twórców metody krytycznej, którzy stali się prawdziwymi interpretatorami i pośrednikami Biblii i którym przypisuje się rolę zbieżną z rolą ojców w pierwszych wiekach. Oznacza to, że uległo rozmyciu pojęcie wspólnych ojców - podzieleni chrześcijanie mają swoich własnych, niejako partykularnych ojców. Także w tym fakcie wyraża się podział Kościoła, który, widoczny w tym miejscu, jest przekazywany dalej. Rzeczywiście jest faktem, że „nauczono się myśleć i mówić o różnych «ojcach»"14. Co więcej, nawet tam, gdzie w Kościele przypisuje się wielkie znaczenie ojcom z pierwszych wieków, samo rozumienie ojców uległo modyfikacji, najczęściej ze szkodą dla ich autorytetu w dziedzinie wiary. Wydaje się więc, że przed teologią współczesną pojawia się pilne zadanie określenia tego, co decyduje o trwałym, a więc także uniwersalnym znaczeniu ojców. „Ojcowie średniowieczni” - jeśli zgodzimy się na takie określenie w stosunku do teologów średniowiecznych, na przykład św. Tomasza z Akwinu - czy też „ojcowie-twórcy” poszczególnych wyznań chrześcijańskich, są i pozostaną ojcami tylko w sensie cząstkowym, nawet jeśli ich zasięg jest bardzo rozległy, jak na przykład wspomnianych Tomasza z Akwinu czy Lutra. Chrześcijanie należący do różnych wyznań zaczną tak naprawdę rozumieć się na nowo, jeśli zaczną rozumieć ojców z pierwszych wieków. Ponieważ bliżsi czasowo ojcowie jednych nie mogą stać się ojcami dla drugich, trzeba zwrócić się do tych, którzy kiedyś byli ojcami jednych i drugich.

Jaki okres historyczny należy uznać za okres ojców chrześcijaństwa niepodzielonego? Odpowiedź na to pozornie akademickie

14 Por. J. Ratzinger, Die Bedeutung, s. 146. 
pytanie może przyczynić się do lepszego zrozumienia zarówno pojęcia „ojca Kościoła”, jak również „Kościoła ojców”. W odpowiedzi na to pytanie bardzo dużego znaczenia nabrała dyskusja, którą wywołał na początku lat sześćdziesiątych André Benoît ${ }^{15}$. Z jednej strony odrzucił czysto historyczne wcześniejsze próby opracowania definicji pojęcia, jak uczynił w XIX wieku Franz Overbeck. Z drugiej jednak strony krytykował także katolickie rozumienie ojców, odwołujące się do czterech klasycznych znamion:

- or to doksji, którą przeżywa wspólnota Kościoła;

- świętości zgodnej z rozumieniem starożytnego chrześcijaństwa;

- bezpośredniego u znania ze strony Kościoła;

- starożytności (antiquitas) ${ }^{16}$.

Mimo wielorakich krytyk podniesionych pod adresem tego tradycyjnego ujęcia wydaje się jednak, że właśnie weryfikacja tych znamion pozwala na wypracowanie definicji - zarówno chronologicznej, jak i jakościowej - pojęć ojca Kościoła i Kościoła ojców. Tutaj ograniczamy się do analizy pojęcia ortodoksji i starożytności, które mają pierwszorzędne znaczenie. To one pozwalają najlepiej określić to, co jest wspólne dla ojców.

\subsection{ORTODOKSJA OJCÓW KOŚCIOŁA}

Należy przede wszystkim stwierdzić, że teologia ojców nie jest wolna od rozmaitych błędów - dotyczy to nawet tych ojców, którzy są powszechnie uznani za „obrońców ortodoksji”. Trzeba jednak od razu zauważyć, że dostrzegane błędy mają różny charakter oraz mogą dotyczyć pojawiania się nowych kwestii lub są zauważane w procesie formacji doktryny dopiero w świetle jej późniejszego rozwoju. Niektóre błędy zostały odkryte szybko i jednoznacznie, podczas gdy inne ujawniły się dopiero w świetle błędnego rozwoju, jaki spowodowały. Oznacza to zatem, że kwestia ortodoksji nie tyle jest kwestią teologii osobistej, ile raczej ma charakter eklezjalny.

15 Por. A. Benoît, L'actualité des Pères de l'Église, Neuchâtel 1961.

16 Por. J. Czuj, Patrologia, Poznań 1954, s. 6-8; F. Drączkowski, Patrologia, s. 7-8. 
Każdy myśliciel może się odnosić bardziej lub mniej pozytywnie i konstruktywnie do doktryny wiary, która istnieje przed nim, ale tym bardziej znajdzie się w niebezpieczeństwie oddalenia się od tej doktryny, im bardziej będzie ufał sobie samemu. I na odwrót, jego teologia będzie tym bardziej owocna, im bardziej przekroczy siebie w kierunku Kościoła. Chodzi o to, by ograniczoność osobista była akceptowana i przekraczana w środowisku komunii eklezjalnej, czyli - jak mówią ojcowie - w uznaniu Kościoła za Matkę. Ta sytuacja sprawia również, że to, co jest dobre w teologii „osobistej”, może zostać przyjęte jako wspólne dziedzictwo wszystkich wierzących. Przyjęcie następuje nie dlatego, że coś powiedział taki czy inny sławny autor, ale dlatego, że ten czy inny autor był autentycznym i oryginalnym interpretatorem wiary Kościoła. Z tego punktu widzenia teologia Augustyna cieszy się w Kościele dominującą pozycją (nawet Tomasz z Akwinu jej nie zagraża) z powodu podjętego przez niego wysiłku wyrażenia, przy zaangażowaniu także jego bardzo oryginalnej osobowości, obiektywnej doktryny Kościoła. Dlatego również może przyczynić się do jej autentycznego rozwoju i rozwiązania kluczowych kwestii.

Obiektywna wartość doktryny (ortodoksji) zależy od miary jej uniwersalności, która wynika z równowagi między podmiotowością teologii i eklezjalnością wiary. Ta zasada zostaje potwierdzona w historii teologii następującej po epoce patrystycznej. Także czołowi teologowie epok późniejszych, będący synonimami ortodoksji, jak Tomasz z Akwinu, Bonawentura czy Robert Bellarmin, zawsze z powodów osobistych mogą być w jakiś sposób krytykowani jako teologowie, ale zachowują symboliczne i istotne znaczenie jako teologowie eklezjalni, to znaczy jako ci, którzy wpisują się w Kościół jako części, przez które wyraża się całość, i którzy nie wyrażają się inaczej, jak tylko jako części całości. Augustyn zrozumiał znaczenie tej zasady i uczynił ją swoją, podczas gdy np. Tertulian - z pewnego punktu widzenia - tego nie uczynił i oddalił się od Kościoła. Ojcowie są więc autentycznymi interpretatorami Pisma Świętego i wyjątkowo autorytatywnymi nośnikami Tradycji, to znaczy są wzorcowo ortodoksyjni, ponieważ są równocześnie oryginalni i eklezjalni. Nie dlatego, że wypracowali teologię 
bezdyskusyjną we wszystkich jej punktach, ale ponieważ zostali uznani za autentycznych interpretatorów wiary Kościoła, który ich poprzedził, do którego wnieśli swój wkład i któremu przyznali władzę korygowania, bezpośrednio lub po pewnym czasie, swoich teologii osobistych. Właśnie w tym uniwersalnym kontekście eklezjalnym, w którym poruszali się ojcowie, trzeba widzieć ich pierwszeństwo w stosunku do teologów należących do innych epok teologii, w których działano już w kontekście Kościoła podzielonego i opracowano teologie, które nawet pogłębiły podział, jak miało miejsce w przypadku tak zwanych teologii konfesyjnych po reformacji w XVI wieku.

Takie ujęcie oznacza pewną „relatywizację” wartości ojców, mającą na celu uwzględnienie korekt spowodowanych redukcjami katolickimi i reformowanymi, o których była mowa. Chodzi o to, by uważać poszczególnych ojców nie za niepodlegających żadnym zastrzeżeniom, ale za niewątpliwie ważnych w ich wzajemnej korelacji, a następnie w relatywności wszystkich w stosunku do Kościoła, który nadal wędruje w historii i pozostaje dla wszystkich przewodnikiem i nauczycielem. Krótko mówiąc, jest słuszne, aby także autentyczni nauczyciele zostali podporządkowani temu, co możemy nazwać instancją krytyczną Kościoła. Tylko w tym kontekście można stwierdzić, że ojcowie - tak zdefiniowani w odniesieniu do ortodoksji - uczynili także coś więcej niż nauczyciele eklezjalni w każdej innej epoce.

Pojawia się tutaj pytanie o to, do kiedy można mówić o ojcach $\mathrm{w}$ tym sensie i o specyficznym autorytecie, jaki mają w stosunku do innych epok wiary i teologii. Pozostaje więc zasadniczą kwestią przeanalizowanie znamienia starożytności, które ich definiuje.

\subsection{STAROŻYTNOŚĆ OJCÓW}

Jest rzeczą bardzo trudną ustalenie, kiedy kończy się starożytność chrześcijańska. Z drugiej strony szacunek dla przeszłości nie może mieć charakteru mitycznego ani muzealnego. W chrześcijaństwie starożytność nie oznacza większej bliskości w stosunku do źródła, jak uznaje Platon; nie oznacza także, że to, co zostało 
powiedziane później, oddala się stopniowo od czystości początków, w wyniku czego pojawia się konieczność oparcia się na przeszłości, by zachować te wartości, które w przeciwnym razie zostałyby utracone. W Kościele rzeczy wyglądają inaczej. Oczywiście także dla chrześcijan jest wiążące i normatywne wydarzenie pierwotne, które znajduje się w przeszłości, ale nie sytuuje się ono na tym samym poziomie co element pierwotny w micie, który nadaje autorytet temu, co starożytne, tylko dlatego, że takie jest. Historyczne działanie Boga jest rzeczywiście także ciągle nowe, w wyniku czego przekracza i jakby anuluje mit starożytności, obejmując element aktualności, który jest połączony z elementem pierwotnym w taki sposób, że z ich integracji wynika zawsze coś nowego. Na tym polega zasadnicza różnica między zasadą mityczną tradycji i zasadą Tradycji eklezjalnej, którą wypracowali ojcowie, a której istotą jest „teraźniejszość w wierze”17.

Ojcowie spełniają funkcję wiążącą i normatywną w Kościele w dziedzinie doktryny chrześcijańskiej, ale nie dlatego, że są po prostu „starożytni”, a więc chronologicznie bliżsi początkom, czyli Nowemu Testamentowi. Autorytatywność ich interpretacji biblijnej i świadectwa wiary, jaka z tego wynika, może wynikać tylko z faktu, że w szczególny sposób przynależą oni do wydarzenia pierwotnego bądź też są z nim związani w jakiś sposób wspólnotą, która ma znaczenie wyjątkowe pod względem teologicznym. Innymi słowy Pismo Święte i ojcowie należą do siebie nawzajem jak słowo i pierwotna odpowiedź, która utrwala słowo. Ponieważ rzeczywistość słowa zakłada relację mówienia i słuchania, tak że jeśli nie ma tego, kto słucha, słowo pozostaje nieskuteczne, także słowo Boże żyje i jest skuteczne tylko wtedy, gdy idzie za nim odpowiedź. Oczywiście słowo Boże zawsze przekracza możliwości ludzkiej odpowiedzi, dlatego też wysiłek Kościoła i jego teologii nastawiony na zrozumienie słowa powinien być podejmowany ciągle na nowo, nie może zostać zablokowany w żadnej fazie jego rozwoju. $\mathrm{Z}$ tego samego powodu jednak także słowa nie można rozumieć, abstrahując od

17 J. Ratzinger, Stowo Boga. Pismo - Tradycja - urzad, tłum. W. Szymona, Kraków 2008, s. 64. 
odpowiedzi, które zostały już udzielone na podstawie dokonanej recepcji i które stały się częścią integrującą siły tego słowa, także w przypadku, w którym taka odpowiedź może i powinna być krytykowana jako niewystarczająca. Trzeba w tym miejscu przyznać, że Kościół patrystyczny doszedł do odpowiedzi, które stały się podstawą dla odpowiedzi udzielanych w okresach późniejszych.

W tej perspektywie trzeba powrócić do początkowego pytania, które może wydawać się banalne, dotyczące granic chronologicznych epoki patrystycznej. Zbyt radykalne wydaje się ujęcie Basila Studera (zresztą bardzo szeroko akceptowane), który proponuje uznać rok 451, czyli rok soboru chalcedońskiego, za datę wyznaczającą koniec epoki patrystycznej. Łączy tę datę ze słynnym kanonem 28, mówiącym o przywilejach stolicy w Konstantynopolu, który zdaje się wyznaczać linię faktycznego podziału między Kościołem wschodnim i Kościołem zachodnim ${ }^{18}$. Idąc po linii zasady, według której ojcowie są nauczycielami Kościoła niepodzielonego, André Benoît zamyka epokę patrystyczną w roku 1054. Data ta wydaje się jednak zbyt przypadkowa, gdyż w rzeczywistości już od pewnego czasu na Wschodzie myślano w sposób inny niż na Zachodzie oraz istniały już liczne teologie „partykularne”, oddalające się od ducha teologii pierwszych wieków.

Trzeba więc stwierdzić, że epoka patrystyczna kończy się wraz z rozbiciem duchowym, na które wskazuje wędrówka ludów z jednej strony oraz inwazja arabska $\mathrm{z}$ drugiej strony. Wyraz eklezjalny tego faktu może być widziany w tym, że ojcowie zwrócili się do monarchii karolińskiej, burząc ostatecznie starożytną ekumenę, i że w relacji do powstania Kościołów pod pewnymi względami „państwowych” zaczęła kształtować się nowa świadomość w Kościele zachodnim. Określenie chronologiczne epoki patrystycznej należy związać więc z tym, co wydarzyło się w Kościele, a nie na odwrót. Ojcowie są nauczycielami teologii Kościoła niepodzielonego, a ich teologia jest eku menic z n a w pierwotnym znaczeniu tego słowa,

18 Por. B. Studer, Die Kirchenväter, [w:] Mysterium salutis, t. 1: Die Grundlagen heilsgschichtlicher Dogmatik, hrsg. von J. Feiner, M. Löhrer, EinsiedelnZürich-Köln 1965, s. 594. 
to znaczy należy do wszystkich. Oni są więc o j c a mi nie tylko dla jakiejś części, ale dla całego Kościoła - i właśnie dlatego są ojcami. Wydaje się, że właśnie dlatego teologia, która była teologią Kościoła zjednoczonego, może przyczynić się do odbudowania historycznej jedności Kościoła. Chociaż uznaje się Kościół katolicki za prawdziwego dziedzica teologii patrystycznej, jednak trzeba stwierdzić z przekonaniem, że cierpi on z powodu istniejącego podziału oraz będzie mógł podjąć w pełni swoje zadanie „katolickie”, gdy wszyscy chrześcijanie uznają konieczność teologii, która w swojej jedności i wielości będzie - z jednej strony - zwierciadłem, a z drugiej fundamentem jedności Kościoła w jedności jego wyrażeń historycznych, geograficznych oraz pojęciowych i organizacyjnych.

Decydujący i nieusuwalny wkład ojców - z punktu widzenia teoretycznego, jak i praktycznego - w opracowanie doktryny Kościoła wynika z ich szczególnego wkładu wniesionego do opracowania niektórych decydujących zagadnień dotyczących teologii eklezjalnej i teologii Kościoła. Wyodrębnienie tego specyficznego wkładu może mieć wartość - także dzisiaj - dla wszystkich chrześcijan, gdy właściwie musimy zmierzyć się z tymi samymi zagadnieniami, z którymi zmagali się ojcowie Kościoła.

\section{ZNACZENIE OJCÓW DLA TEOLOGII KATOLICKIEJ}

Jak już zostało wstępnie zaznaczone, ojcowie Kościoła odgrywają decydującą rolę $\mathrm{w}$ daniu podstaw wierze, ponieważ ich uprzywilejowana relacja z Pismem Świętym czyni ich również uprzywilejowanymi świadkami Tradycji Kościoła ${ }^{19}$. Jest to tym bardziej prawdziwe, że w Kościele Pismo Święte jest zawsze czytane - świadomie lub nie - w oparciu o myśl tych, którzy jako pierwsi podjęli prace

19 O znaczeniu ojców Kościoła w świetle wypowiedzi kościelnych zob. w: PawełVI, Przemówienie na otwarcie Instytutu Patrystycznego "Augustinianum” (4 maja 1970), „Vox Patrum” 4 (1983), s. 15-20; Jan Paweł II, Przemówienie do profesorów i studentów Instytutu Patrystycznego „Augustinianum” (8 maja 1982), „Vox Patrum” 4 (1983), s. 21-28; Kongregacja ds. Wychowania Katolickiego, Instrukcja o studium Ojców Kościoła w formacji kapłańskiej, „Vox Patrum” 10 (1990) t. 18, s. 7-39. 
zmierzające do zrozumienia słowa Bożego, które w pewnym sensie mogą być widziane jako demitologizacja ante litteram. Oczywiście, ponieważ możliwości odpowiedzi na wydarzenie Jezusa Chrystusa są bardzo szerokie, to wynika z tego, że odpowiedź mogłaby być inna, jeśli zamiast w świecie grecko-łacińskim rozwinęłaby się w innym środowisku kulturowym. Odpowiedzi, które dali ojcowie, zawierają więc w sobie zarówno coś historycznego i przejściowego, jak również coś definitywnego i nieodwołalnego. W cytowanej wyżej rozprawie André Benoît, a za nim Joseph Ratzinger wskazali na cztery kluczowe punkty, w których wyraża się pewna ostateczność, a więc i nieusuwalność, odpowiedzi danej przez ojców. Pośrednio zawiera się także kwestia piąta, a mianowicie dotycząca natury i warunków istnienia Kościoła. Ta propozycja jest szeroko akceptowana. W świetle najnowszych badań nad wkładem ojców Kościoła do teologii odpowiedź ta zyskuje wielorakie potwierdzenie. Opowiadam się za nią w szukaniu znaczenia ojców dla dzisiejszej teologii i życia Kościoła.

\subsection{KANON BIBLIJNY}

Czasu ojców i oczywiście Kościoła niepodzielonego sięga kanon Pisma Świętego. Było dziełem ojców dokonanie rozróżnienia między wieloma pismami żydowskimi i chrześcijańskimi, które doprowadziło do określenia, czym jest Scriptura i co się na nią składa ${ }^{20}$. Ukonstytuowanie się kanonu i ukonstytuowanie się Kościoła pierwotnego to dwa korelatywne aspekty właściwie jednego i tego samego procesu. Kanon, który tylko z tej racji, że jest owocem kompleksowej i niejednokrotnie bolesnej wędrówki rozróżniania i decyzji, może być traktowany także dzisiaj jako definitywny, byłby jednak nie do pomyślenia bez ojców. Przyjęcie kanonu powinno więc oznaczać zaakceptowanie teologii, która go wypracowała, oraz Kościoła, który doprowadził go do dojrzałości i przyjął za normę swojego

20 Por. B. Metzger, The Canon of the New Testament. Its origins, development and significance, Oxford 1987; L. M. McDonald, The formation of the Christian Biblical Canon, Nashville 1995. 
nauczania i życia. Mamy w tym wypadku do czynienia z pomnikowym osiągnięciem ojców, nawet jeśli kwestia kanonu zawsze była dyskutowana i w dalszym ciągu pozostaje przedmiotem ożywionej dyskusji ${ }^{21}$.

\subsection{REGULA FIDEI}

Kryterium zastosowane do wyboru ksiąg, które miały stać się Biblią, było następujące: kánon tês pisteos, regula fidei, regula veritatis $^{22}$. Pisma nie mogły być regułą same dla siebie, ale musiały być czytane w oparciu o kryterium, czyli o kanon, który potem ukonstytuował ze swej strony Biblię jako kanon. Regula fidei przedłużała się i krystalizowała w różnych symbolach, zwłaszcza soborowych, chociaż nie tylko, oraz w poszczególnych dogmatach, w oparciu o które Kościół coraz bardziej precyzował swoją tożsamość doktrynalną wierną Ewangeliii ${ }^{23}$. Kościół ojców stoi w ten sposób u początku podstawowych wyznań wiary mających istotne znaczenie dla całego chrześcijaństwa, zarówno ówczesnego, jak i późniejszego, a paradoksalnie także dla chrześcijaństwa podzielonego. Wyznawanie dzisiaj wiary oznacza nawiązanie kontaktu i komunii z ojcami, którzy jako pierwsi opracowali te formuły zarówno w celu pozytywnego wyrażenia wiary, jak i w celu zwalczenia błędów. Jednak to wyznawanie wiary oznacza także przyjęcie Kościoła, który stał za tymi symbolami, które - na równi z Pismem Świętym - nie są sformułowaniami niezależnymi od wspólnoty wierzącej, ale zakładają zrozumienie wiary całego Kościoła, w ramach którego narodziły się i dzięki któremu mogą zachować się przy życiu. Nieuznawanie tego byłoby szkodliwe nie tylko dla samozrozumienia Kościoła katolickiego, ale także dla dialogu ekumenicznego.

21 Por. Les canon des Écritures. Études historiques, exégétiques et systematiques, red. C. Theobald, Paris 1990.

22 Por. J. Królikowski, Zakorzenić się w Tradycji Kościoła. Dlaczego powinniśmy czytać Ojców Kościoła?, [w:] Świadkowie naszej Tradycji. Pisma Ojców Kościoła, tłum. W. Kania, red. J. Królikowski. Ł. Winczura, Tarnów 2000, s. 307-323. Por. B. Sesboüé, L'Évangile et la Tradition, Paris 2008, s. 97-110. 


\subsection{PIERWSZEŃSTWO LITURGII}

Lektura Pisma Świętego i wyznanie wiary zawsze były aktami liturgicznymi i doksologicznymi wspólnot kościelnych zjednoczonych w swoim życiu wokół Zmartwychwstałego ${ }^{24}$. W ten sposób Kościół starożytny wypracował i określił podstawowe formy liturgii, które należy traktować jak stały i nieusuwalny punkt odniesienia dla każdej odnowy liturgicznej. Wiadomo, że ruch liturgiczny - zarówno ze strony katolickiej, jak i protestanckiej - znalazł właśnie u ojców żywe źródła, które pozostają niezastąpione także w dzisiejszych potrzebach dotyczących uzasadnienia i rozwijania kultu Bożego.

Dlatego liturgia, która w imię „nowoczesności” odrzuciłaby więź z Tradycją, a więc z Kościołem starożytnym, w gruncie rzeczy nie ograniczyłaby się do wyzwolenia - co jest słuszne - z archaizmu, jak i romantyzmu obecnego w pewnej mierze w ruchu liturgicznym, ale odrzuciłby także więź z podstawowymi formami starożytnej modlitwy chrześcijańskiej, to znaczy z modlitwą eklezjalną każdego czasu. Jest to kwestia, której trzeba stale stawiać opór. Powinni na to zwrócić uwagę także protestanci, których liturgia od początku cierpi z powodu swojego oddalenia od wspólnego dziedzictwa liturgicznego. Oznacza to, że także w dziedzinie liturgii kryterium starożytnej Tradycji - Tradycji Kościoła jeszcze niepodzielonego jest drogą prowadzącą do jedności.

\subsection{TEOLOGIA FILOZOFICZNA}

Ojcowie uprawiali teologię, rozumiejąc ją jako philosophia, stawiając ją w perspektywie programu: credo ut intelligam oraz uznając w ten sposób swoją własną odpowiedzialność racjonalną w stosunku do wiary ${ }^{25}$. Ta metoda zachowała się w chrześcijaństwie aż do

24 Por. G. Wainwright, Doxology. The praise of God in worship, doctrine and life, dz. cyt.

25 O znaczeniu wypracowania przez ojców Kościoła podstaw metody teologicznej, to znaczy wykorzystania refleksji racjonalnej w poszukiwaniu rozumie- 
dzisiaj, mimo wielu różnic i napięć, które ją dotykają. To racjonalne ukierunkowanie wiary i teologii na początku nie było wcale oczywiste, ale szybko zostało przyjęte za faktyczne, ponieważ jego punktem odniesienia był starożytny świat grecko-rzymski, mocno dowartościowujący filozofię, który domagał się konfrontacji tego rodzaju. To ukierunkowanie racjonalne zachowało swoją wagę aż do dzisiaj w Kościele zachodnim. Idąc za tym programem, Kościół zachowuje swój wpływ ewangelizacyjny w całym świecie. „Racjonalizm” ojców i całej teologii przynosi owoce także wtedy, gdy jest krytykowany, jak czynią zwłaszcza protestanci, oraz niedoceniany, jak ma niejednokrotnie miejsce także w kręgach kościelnych. Co więcej, jedna z poważnych przyczyn dzisiejszych trudności wiary powinna być widziana w podwójnym fakcie: $w$ tym, że teologia zrezygnowała $\mathrm{z}$ konfrontacji z filozofią, oraz $\mathrm{w}$ tym, że sama filozofia w znacznym stopniu zrezygnowała ze swojego specyficznego, a właściwie najwyższego zadania, jakim jest dociekanie dotyczące bytu.

\subsection{EKLEZJALNOŚĆ OJCÓW}

Jak widać, wszystkie wymienione elementy dotyczące znaczenia ojców dla teologii mają jakiś związek z eklezjologią, ponieważ dotyczą tego, w co Kościół wierzy, oraz narzędzi, za pośrednictwem których wyraża swoją wiarę. W nich wyraża się trwałe znaczenie ojców w teraźniejszości i przyszłości teologii i wiary Kościoła. Wydaje się więc więcej niż logiczne zapytanie, jaką eklezjologię prezentują ojcowie, skoro prowadzi ich do tak konkretnych i tak trwałych rezultatów.

Ze wskazanych czterech punktów wynika, że im bardziej jest się w stanie pokazać, że ojcowie - mimo wielości stanowisk, a niekiedy błędów materialnych - są w stanie sformułować uniwersalną odpowiedź na uniwersalność Pisma Świętego, tym bardziej mogą mieć znaczenie jeszcze dzisiaj i w przyszłości jako nauczyciele Kościoła

nia wiary zob. w: J. H. Newman, Logika wiary, tłum. P. Boharczyk, Warszawa 1989, s. 121-128. Por. także J. Ratzinger, Nauczanie Ojców Kościoła w encyklice „Fides et ratio” Jana Pawta II, „Vox Patrum” 18 (1998), t. 34-35, s. 303-310. 
katolickiego i jako siła sprzyjająca jedności z Kościołami i wspólnotami eklezjalnymi. Jeśli zaś chodzi o średniowiecze i epokę nowożytną, to mimo większej precyzji dogmatycznej teologie tych epok mogą być rozmaicie kwestionowane z powodu ich zdecydowanie mniejszej uniwersalności, która, owszem, może być odzyskana, ale pod warunkiem że wierzący w Kościele w większym stopniu oddadzą się słuchaniu słowa Bożego i włączą w dialog, jaki z tym słowem nawiązali ojcowie. Istotny wkład ojców do teologii Kościoła ich czasu stanowi także zaproszenie do pracy ekumenicznej nad jednością dzisiejszego Kościoła. Mimo faktycznego prezentowania wielu eklezjologii, ojcowie są świadkami jedności doktryny chrześcijańskiej i Kościoła.

Można więc powiedzieć, że właśnie poznanie historyczne ojców pozwala stosować ich myśl i ich praktykę także w czasach obecnych. Przede wszystkim ten, kto wpisuje się w historię, może ją przekroczyć, a kto nie chce zdać sobie z niej sprawy, zostaje w niej uwięziony, tracąc tym samym wszelką szansę, aby czytać ją w sposób rzeczywiście historyczny, mimo że odwołuje się do metody historycznej. Komplementarnie ujmując, zażyłość z ojcami nie polega na czystej pracy katalogowania dotyczących ich faktów w muzeum, gromadzącym pamiątki z przeszłości. Ojcowie stanowią wspólną przeszłość wszystkich chrześcijan i w ponownym odkryciu tej wspólnoty znajduje się nadzieja przyszłości Kościoła oraz stojące przed nami zadanie pracy nad nią. W taki sposób poznanie przeszłości oznacza także przygotowywanie przyszłości, w której dojdzie do jednoczącego pojednania wszystkich chrześcijan.

\section{ZADANIA NA PRZYSZŁOŚĆ}

Program wyjścia na nowo od ojców, mając na względzie odnawianie Kościoła naszego czasu zgodnie z najlepszymi osiągnięciami współczesnych poszukiwań teologicznych, powinien polegać na inteligentnym i wytrwałym wysiłku stwierdzenia jedności wiary i Kościoła za pośrednictwem metody, która z badania historycznego prowadzi spontanicznie do dogmatu, nie usiłując sprowadzić historii do schematów dogmatyki, która została wypracowana w epokach 
późniejszych. Kościół katolicki stoi wobec odpowiedzialności, która wynika z jego dziedzictwa patrystycznego, nie zaciemniając jego ograniczeń. Odnowienie Kościoła musi być oczywiście powiązane z pogłębionym i odnowionym dowartościowaniem Pisma Świętego i ojców, ale tylko w takiej mierze, w jakiej sam Kościół żyje dzisiaj tym samym Duchem, który podpowiedział ojcom odpowiedź wiary i wyposażył ich w narzędzia intelektualne zdolne do zmierzenia się z pojawiającymi się kontrowersjami. Kościół rozwija się bowiem według dynamiki historycznej - jako Ciało Chrystusa żyje, porusza się, wzrasta i odnawia się w dziejach. Z jednej więc strony chrześcijaństwo nie może zostać dzisiaj wymyślone na nowo, odrzucając przeszłość; z drugiej strony nie może opierać się tylko na dosłownych stwierdzeniach Pisma Świętego lub na formach Kościoła wypracowanych przez ojców, ponieważ oznaczałoby to rezygnację z życia i przynoszenia nowych owoców.

Nadając więc podstawowe znaczenie Pismu Świętemu i ojcom, nie możemy ograniczać się tylko do powrotu do początków, jakie są zawarte w Piśmie Świętym i u ojców. Równie ważne jest to, co zostało wypracowane w późniejszych epokach. Rzeczywista ciągłość i tożsamość z początkiem jest obecna tylko tam, gdzie wspólnota żyje, rozwijając początek, i właśnie w ten sposób pełni posługę czuwania nad jego i swoją tożsamością. Ojcowie są oczywiście wzorem, za którym trzeba iść, ale nie można zatrzymać się na nich, ponieważ w każdym czasie Duch Święty tworzy rzeczy nowe, chociaż na gruncie tego, co zostało już powiedziane bądź uczynione. Przykładem tego jest II Sobór Watykański. Jego niewątpliwą zasługą jest odnowa eklezjologii katolickiej na gruncie struktury Kościoła patrystycznego, ale została ona dokonana w oparciu o sprecyzowania teologiczno-dogmatyczne dojrzałe w kolejnych epokach, w których nadal działał Duch Święty, a człowiek nadal dokonywał twórczego przyjęcia tego działania. Dynamiczna koncepcja Tradycji w Kościele zakłada dowartościowanie każdego słowa powiedzianego i zapisanego w przeszłości, ale domaga się równocześnie przekroczenia litery w teraźniejszości, w której działa Duch Święty. Tutaj ujawnia się zasadnicze ograniczenie dotyczące ojców. Jeśli nauczyliśmy się czegoś od nich, to właśnie po to, by żyć tym 
w dniu dzisiejszym, podejmując nasze własne zadania i wprowadzając w życie nasze osiągnięcia. Sięgamy więc do skarbów żywej Tradycji, ale mamy na względzie przede wszystkim teraźniejszość.

Drugi wątek, który zasługuje dzisiaj na szczególne dostrzeżenie, dotyczy tej wartości ojców, którą oni mają nie tylko jako poszczególni teologowie, ale jako eksponenci żywego Kościoła, który w swojej całości powiedział i uczynił coś definitywnego dla chrześcijan wszystkich czasów. Ta eklezjalność ojców przenika teologię i integruje jej funkcję eklezjalną. Zasada pneumatologiczna nieustannie jest obecna i operatywna w Kościele, nie została ona zamknięta wraz z epoką patrystyczną oraz domaga się, by ciągle na nowo wprowadzać ją w życie i stale szukać nowych możliwości realizacji tego zadania eklezjalnego.

Zwracanie się do ojców obejmuje więc dwie składowe: bezpośrednią wolę przyznania im prawdziwie uprzywilejowanego miejsca (jest w nich coś z definitywności samego objawienia) oraz bezpośrednią świadomość, że także oni są tylko etapem wędrówki Kościoła w czasie. Tylko w oparciu o te dwie zasady, podobnie jak Kościół w przeszłości uznał takiego czy innego teologa za swojego, Kościół każdego czasu ma kontynuować refleksję teologiczną nad depozytem wiary, a autentyczne i twórcze wyniki tej refleksji może przyjmować za część swojej nauki i zgadzać się na uleganie ich wpływowi. Warunkiem tego procesu jest eklezjalność refleksji teologicznej, jak dzięki eklezjalności obecna wiara chrześcijańska jest wiarą początków. Na gruncie zatem tego, co św. Augustyn nazywa „pamięcią” Kościoła, będzie on mógł zaakceptować każdego eksponenta myśli chrześcijańskiej zarówno w jego wielkości, jak i w jego ograniczeniach. 
ROZDZIA X

\section{来 \\ Teologiczne i duchowe znaczenie historii Kościoła}

Historia jest Wielką Tajemnicą i w swych kształtach, i w swej treści.

ks. Czesław S. Bartnik ${ }^{1}$

W podsumowaniu zachowującego ciągle aktualność studium na temat rozwoju pojęcia historii Kościoła Romuald Gustaw OFM pisał: „Myśl chrześcijańska obecnych czasów [...] w jakimś szczególnym sensie stanęła wobec problemu historii Kościoła, rozumiejąc ją przede wszystkim jako dyscyplinę służącą samouświadomieniu, poznaniu istoty i zasadniczych podstaw Kościoła, czynników jego wzrostu i rozwoju. Wypracowana przez współczesną eklezjologię definicja Kościoła, przyjmująca, iż jest on nowotestamentowym ludem Bożym, zmierzającym do realizacji królestwa Bożego na ziemi, a równocześnie istniejącym jako pełne tajemnicy Corpus Christi Mysticum, każe określić dzieje Kościoła jako proces realizacji tego królestwa, widziany w świetle transcendentnego planu Bożego. A zatem, jak słusznie zauważa Jedin:

1 C. S. Bartnik, Teologia historii, Lublin 1999, s. 9. 
«Heisgeschichte nie jest jedną, ale jedyną adekwatną interpretacją historii Kościoła». Jesteśmy więc niewątpliwie świadkami jakiejś bardzo żywej recepcji pojęcia historia sacra w historiografii kościelnej. I tak jak w starożytności chrześcijańskiej, jak w wiekach średnich i jak w dalszych okresach, tak i dziś historia Kościoła rozwijająca się w ramach tejże koncepcji może i powinna być jedną z nauk teologicznych, ważnym ogniwem w procesie zdobywania prawdy o Bogu i Jego Kościele”2.

Po ponad pięćdziesięciu latach od napisania tej uwagi okazuje się ona jeszcze wymowniejsza i aktualniejsza. Zostało wykazane w wielu miejscach, zarówno na gruncie refleksji filozoficzno-teologicznej ${ }^{3}$, jak i na gruncie badań ściśle historycznych, że historia Kościoła może wnieść bardzo znaczący wkład w poznanie Boga oraz w poznanie Kościoła w aspekcie jego natury i rozwoju oraz jego życia teologalnego, mającego charakter zbawczy. Historia pokazuje ponadto rzecz zasadniczą, a mianowicie zasięg i skuteczność oddziaływania prawdy o Bogu w historii oraz rezultaty, które życie teologalne przynosi w działaniu konkretnych wiernych. $\mathrm{Z}$ tego powodu badania dotyczące dziejów Kościoła niejednokrotnie bywają pomniejszane w swoim znaczeniu ze względów ideologicznych, a ich wartość dla kultury ogólnoludzkiej bywa w dużym zakresie kwestionowana. Mimo niesprzyjającego klimatu należy postawić na dalszy rozwój badań dotyczących dziejów Kościoła, zwłaszcza w jego wymiarze partykularnym i w jego wszelkiego rodzaju przejawach lokalnych, które chwytają życie wiary, będące ośrodkiem rzeczywistości Kościoła, w pełnej autentyczności, realizmie i znaczeniu osobowym. W wymiarze lokalnym Kościoła chwyta się niejako "na żywo" jego istotę, która niejednokrotnie wydaje się tak bardzo abstrakcyjna. Tylko przez poznawanie konkretnych i niepowtarzalnych doświadczeń osobowych - których źródłem jest wiara, a które urzeczywistniają się w środowisku Kościoła lokalnego - w tym

2 R. Gustaw, Rozwój pojęcia historii Kościoła. Od I do XVIII wieku, PoznańWarszawa-Lublin 1964, s. 89.

3 Por. P. Ricoeur, Pamięć, historia, zapomnienie, tłum. J. Margański, Kraków 2006. 
także doświadczeń historycznych, można wyjść poza stereotypy i chwycić coś z autentyczności życia wiary oraz wydobyć jego bezpośrednie skutki. Postępując tą drogą, można wzbogacić swoją wiedzę o dziedzictwie duchowym i zrozumieć, kim się jest za sprawą tego dziedzictwa. Kiedy otworzy się oczy na swoje własne dziedzictwo kościelne, odkrywa się zaskakujące znaczenie tego, co nas otacza, i wtedy można się zaangażować nie tylko w dalsze poznawanie tego dziedzictwa, ale także w jego przekształcanie i twórcze pomnażanie na miarę nowych czasów i nowych potrzeb, które te czasy wyzwalają. Wróżony przez Francisa Fukuyamę „koniec historii" jest ciągle daleki zarówno w życiu społecznym, jak i w życiu kościelnym ${ }^{4}$.

\section{HISTORIA JAKO POZNANIE}

W sensie ścisłym miano historii przysługuje systematycznemu opowiadaniu i krytycznej interpretacji wydarzeń godnych pamięci, które zdarzyły się pojedynczym ludziom albo społeczeństwom. Stefan Swieżawski tak określa historię: „Przeszłość związana z człowiekiem jest tym, co stanowi historię; ściślej, historia jest przeszłością człowieka. Jest to więc cała miniona rzeczywistość, związana z człowiekiem i jego działalnością - wszystko, co minęło, a co wchodziło w zakres materialnej i pozamaterialnej, jednostkowej i społecznej twórczości i wytwórczości człowieka"5. Małgorzata Borkowska OSB w czasie nadania jej tytułu doktora honoris causa przez Katolicki Uniwersytet Lubelski Jana Pawła II, podsumowując swoje rozległe badania historyczne, mówiła w takim samym duchu: „Historia to właśnie sprawa ludzi; przynajmniej tak ją rozumiem i tak ją pisałam. Ludzi; nie instytucji, nie przedmiotów, ale ludzi, którzy czegoś chcieli, coś sobie stawiali za cel, jakoś im to

4 Por. F. Fukuyama, Koniec historii, tłum. T. Bieroń, M. Wichrowski, Poznań $2000^{2}$.

5 S. Swieżawski, Zagadnienie historii filozofii, Warszawa 1966, s. 48. 
wychodziło mniej lub bardziej, i to jest właśnie pasjonujące: odkrywać, jak i dlaczego"6.

Historia jest autentycznym poznaniem, to znaczy rozumieniem ludzkiej przeszłości, która była teraźniejsza dla ludzi, którzy ją przeżyli. Nie jest możliwe oderwanie opowiadania o wydarzeniach z przeszłości od ich interpretacji, to znaczy od poglądu, który historyk ukształtował sobie na temat ich przebiegu. Sztuka pisania historii nazywa się historiografią - chodzi w niej o poznanie historyczne „przelane na papier”. Historiograf posługuje się swoją własną metodologią, którą można określić jako „badanie historyczne". Chodzi o wędrówkę intelektualną, która wychodzi od teraz, chwili nieuchwytnej, jak mówi św. Augustyn, pierwszy wielki filozof czasu, ale niezastąpionej dla określenia tego, czym są dzieje. Ta wędrówka ma jako bezpośredni przedmiot poznanie przeszłości, przy czym jest oczywiście zdolna do jego przyjęcia i zrozumienia, a rezultatem pośrednim tej wędrówki jest lepsze poznanie teraźniejszości, mające na celu zaprojektowanie przyszłości. W niektórych nurtach historiograficznych kwestionuje się takie znaczenie historii, traktując ją wyłącznie jako wiedzę o przeszłości, gdyż jakiekolwiek zwrócenie się do przyszłości miałoby być niespójne z metodą postępowania historycznego. Nie wydaje się jednak, by takie zawężenie było w pełni uzasadnione, ponieważ także doświadczenia historyczne są nośnikiem treści i wartości obiektywnych, które mogą służyć wyprowadzeniu i utrwaleniu pewnych ogólnych przekonań, funkcjonalnych dla teraźniejszości i przyszłości. Mówiąc filozoficznie, stawanie się zawsze zakłada jakąś metafizykę. Wstrzemięźliwe dążenie do uchwycenia przesłania wynikającego $\mathrm{z}$ wydarzeń przeszłych, gdy patrzy się na teraźniejszość, przy równoczesnym zwracaniu uwagi na przyszłość nie powinno być obce badaniu historycznemu. Takie znaczenie i taka rola nauki historycznej w środowisku kościelnym są tym bardziej uzasadnione, że także przedstawiciele tej nauki chcą realnie odpowiadać na potrzebę formacyjną nowych

6 M. Borkowska, Wystapienie, [w:] Katolicki Uniwersytet Lubelski Jana Pawła II, Siostra Małgorzata Borkowska OSB. Doktor honoris causa, Lublin 2011, s. 44 . 
pokoleń, gdyż może bardziej niż inni są oni świadomi, że w uprawianiu historii ostatecznie chodzi o człowieka. Sprawa historii to sprawa ludzkiej autentyczności dzisiaj i w przyszłości. Wynika to z podstawowego faktu, że „człowiek wyłania się z historii, żyje w jej łonie, stanowi jej centrum i sam jest historią"7.

Historia spełnia ważną funkcję antropologiczną. Zostało ponad wszelką wątpliwość wykazane, że nie ma wzrostu osoby bez konfrontacji z przeszłością. Jeśli to przekonanie podlega zakwestionowaniu, głównie na gruncie ideologicznym, czego niejednokrotnie jesteśmy dzisiaj świadkami, to doświadczenia codziennego życia ciągle na nowo wydobywają tę prawdę i pokazują jej żywotne odniesienia egzystencjalne. Ponieważ więc dziejowość jest podstawowym wymiarem człowieka oraz właściwością jego bytu i stawania się, poznanie tej dziejowości nie może być sprowadzone do działalności czysto mechanicznej, czyli do prostego notowania faktów w postaci suchego zapisu kronikarskiego. Myślenie historyczne lub, mówiąc ściślej, „zmysł historyczny” właściwy dla człowieka, to znaczy zdolność do żywego odczuwania upływającego czasu, w którym następują wydarzenia, których podmiotem jest człowiek, „obecnej” przeszłości jako przeszłości, jest szczególną kategorią duchową. Chociaż to odkrycie jest jednym z trwałych osiągnięć epoki nowożytnej, to jego podstaw trzeba szukać już w Starym Testamencie, dla którego pamięć, a więc historia, jest drogą prowadzącą do życia i przeżycia ${ }^{8}$. Biblia ze swoją koncepcją dziejów zainspirowała chrześcijańską teologię, w której namysł nad czasem i dziejami stanowi bardzo ważny obszar poszukiwań ${ }^{9}$. $\mathrm{Z}$ tego podstawowego znaczenia historii dla człowieka wynika również konieczność nauczenia się tego sposobu myślenia i obowiązkowy charakter tej dyscypliny w szkołach każdego typu i stopnia. W dalszych rozważaniach zostanie także pokazane znaczenie tej dziedziny nauki w ramach wszelkiego typu studiów kościelnych.

7 C. S. Bartnik, Historia ludzka i Chrystus. Szkice z chrześcijańskiej wizji dziejów, Katowice 1987, s. 5.

8 Por. J. L. Ska, La strada e la casa. Itinerari biblici, Bologna 2001, s. 55-63.

9 Por. A. Jankowski, Biblijna teologia czasu, Kraków 2004. 
Trzeba tutaj zaznaczyć, że rozumienie przeszłości nie jest osiągane raz na zawsze, ale ciągle musi być poddawane działaniom zmierzającym do jego odnowy. Dokonuje się ono za pośrednictwem tworzonych teorii, korzystając w ich opracowywaniu z poznanych faktów historycznych, które podlegają selekcji i weryfikacji. Nie ma faktów ustalonych raz na zawsze. Bardzo dobrze zilustrował tę kwestię Edward H. Carr, porównując zbieranie faktów historycznych do łowienia ryb: „Fakty nie zawsze wyglądają jak ryby na ladzie sprzedawcy. Przypominają raczej ryby pływające po bezkresnym i czasami kompletnie niedostępnym oceanie. To, do czego dotrze historyk, będzie zależało od przypadku, ale głównie od tego, w jakiej części oceanu zechce łowić i jaką zarzuci wędkę - te dwa czynniki zależą, oczywiście, od rodzaju ryby, na jaką ma ochotę"10.

Interpretacja nie polega na zrekonstruowaniu faktów, ale na ich odnalezieniu, by potem dokonać ich wiernego i poprawnego zreferowania, zgodnie z zachowanymi dokumentami, nie powodując jednak jakiegoś ich duszącego zacieśniania, jak dzieje się w h i s t o r y z m i e, który zwracając się wyłącznie do samych faktów i pretendując do znalezienia w nich wszelkiej prawdy, historię rozumianą jako r ze czywistość podporządkowuje historii rozumianej jako technika lub nawet, mówiąc mocniej, h is tor ię-r ze cz y wis to ść zastępuje przez h i st o ri ę-n a u kę. Jest to stanowisko, które w odniesieniu do dogmatu zaprezentował „ojciec modernizmu” - Alfred Loisy (18571940), którego tutaj wspominamy ze względu na żywotność sformułowanych przez niego propozycji ${ }^{11}$.

W ciągu ostatnich dwóch wieków w ramach swoich poszukiwań historycy doskonalili coraz bardziej wyszukane techniki badawcze, stosując w coraz szerszym zakresie swoje własne rygorystyczne metody, ale "prawda historyczna” w swojej całości nadal pozostaje nieosiągalna. Henri-Irénée Marrou pisze: „To niewiele, które

10 E. H. Carr, Historia. Czym jest. Wyktady im. George'a Macaulaya Trevelyana wygtoszone na uniwersytecie w Cambridge styczeń-marzec 1961, tłum. P. Kuś, Poznań 1999, s. 34-35.

11 Krytyka stanowiska modernistycznego w: M. Blondel, Filozoficzne wyzwania chrześcijaństwa, tłum. J. Fenrychowa, Kraków 1994, s. 35-43. 
nasza wiedza pozwala poznać, umożliwia nam uchwycenie struktury historii, a w swojej rzeczywistości konkretnej objawia ją jako strukturę o takiej złożoności, której myśl nigdy nie może wyczerpać i ująć, by zdefiniować wszystkie nieskończenie cienkie relacje. Historia nigdy nie jest prosta"12. Ponieważ wiedza historyczna jest kwalifikowana przez prawdę, którą jest w stanie osiągnąć, ten sam myśliciel zwraca uwagę na bardzo znaczący problem, sytuujący się po stronie badacza tej dziedziny rzeczywistości: „Wartość poznania historycznego jest $w$ bezpośrednim związku z bogactwem wewnętrznym, inteligencją, zaletami duchowymi historyka, który ją opracował"13. Innymi słowy, historia jest nieodłączna od historyka. Niestety, zbyt często ten element poznania historycznego bywa dzisiaj pomniejszany lub zapominany w imię tak zwanego obiektywizmu badań naukowych, gdy tymczasem należy on do podstawowych cech charakterystycznych poznania historycznego.

\section{HISTORIA KOŚCIOŁA I JEJ PRZEDMIOT}

Zamiast formułować jakąś jedną definicję Kościoła, z której ścisłego opracowania zrezygnowali już teologowie, za II Soborem Watykańskim wystarczy odwołać się do obrazów i metafor, którymi posługują się dla jego opisania Pismo Święte oraz tradycja patrystyczna i liturgiczna: lud Boży, nowy Izrael, Ciało Chrystusa, Oblubienica Chrystusa, matka, rola, dom itd. Tertulian zastosował do Kościoła metaforę łodzi, która odegrała wielka rolę w eklezjologii patrystycznej i w języku eklezjalnym powraca do dnia dzisiejszego.

Aby oznaczyć wzrost Kościoła w czasie i przestrzeni, zdecydowanie najlepsza jest metafora, do której szeroko odwołuje się św. Wincenty z Lerynu (Lérins, † 450). Dokonuje on zestawienia Kościoła z rozwijaniem się ciała ludzkiego i ziarna, które zawiera już wszystko, co decyduje o naturze tego, co z niego wyrośnie, i o jego właściwościach ${ }^{14}$. Oznacza to, że jak z ziarna pszenicznego

12 H. I. Marrou, Teologia della storia, Milano 1979², s. 28.

13 Tenże, La conoscenza storica, Bologna 1962, s. 104.

14 Por. Wincenty z Lerynu, Commonitorium 1, 23: PL 50, 668-669. 
kiełkuje i rozwija się źdźbło, w końcu zwieńczone kłosem, będące pszenicą, tak samo Kościół urzeczywistnia się w procesie historycznym w zmiennych formach, ale jego istota zawsze pozostaje taka sama. Podstawą reguły wiar y (regula fidei) pozostaje universitas, antiquitas i consensus: id teneamus, quod ubique, quod sempre, quod ab omnibus creditum est. Taka jest reguła tego, co katolickie ${ }^{15}$.

Organiczny wzrost Kościoła, zbudowanego na fundamencie apostołów (por. Ef 2, 10) i prowadzonego przez Ducha Świętego (por. J 16, 13), jest istotną kategorią historii Kościoła. W Kościele dokonuje się jednak równocześnie rzeczywisty rozwój, który można widzieć w liturgii i teologii, w prawie i organizacji, w doktrynie i samozrozumieniu. Rozumie się wtedy, dlaczego dekret Optatam totius II Soboru Watykańskiego na temat formacji kapłańskiej daje między innymi następujące zalecenie: „Teologię dogmatyczną należy tak rozplanować, aby najpierw przedstawić tematy biblijne. Dalej trzeba pokazać alumnom wkład Ojców Kościoła Wschodu i Zachodu w wierne przekazywanie i wyjaśnianie poszczególnych prawd objawienia oraz późniejszą historię dogmatu, jak też jej odniesienia do ogólnej historii Kościoła. [...] Podobnie podczas wykładania prawa kanonicznego i przekazywania historii Kościoła trzeba się odnosić do tajemnicy Kościoła zgodnie z Konstytucją dogmatyczną o Kościele" (nr 16).

W perspektywie teologicznej Kościół jest czymś boskim i jest przedmiotem wiary, i tak go widzi teolog; w optyce historyka, który go bada właściwą sobie metodą, Kościół jest natomiast jedną $\mathrm{z}$ wielu instytucji ludzkich. Pojawia się więc zasadnicze pytanie, czy historia Kościoła jest aspektem historii, czy też stanowi jedno z wielu źródeł poznania teologicznego. Słusznie można pytać, czy jest ona "miejscem teologicznym”, jak określił ją Melchior Cano (†1560), dokonując przełomowej systematyzacji różnych źródeł poznania teologicznego oraz ich klasyfikacji w oparciu o kryteria teologiczne ${ }^{16}$.

15 Tamże 1, 2: PL 50, 440.

16 Por. B. Körner, Melchior Cano. De locis theologicis. Ein Beitrag zur Theologie Erkenntnislehre, Graz 1994. 
Chociaż Kościół ma wymiar boski, ma jednak za przedmiot rzeczywiste dzieje. Zaczyna się wraz z Jezusem Chrystusem, który przyszedł na świat, a więc także wszedł w dzieje, przez wcielenie. Jego życie, Jego nauczanie i oddziaływanie tego wydarzenia przedłużają się aż do naszych dni. Sam Jezus zapowiedział, że Jego słowa nie przeminą (por. Mt 24, 35) i Jego królestwo będzie się rozszerzać i rosnąć w sposób przekraczający ludzkie oczekiwania (por. Mt 13; 28, 19).

Wychodząc od tej specyfiki, począwszy od początku formowania się Nowego Testamentu aż do II soboru watykańskiego, ma miejsce debata o relacji zachodzącej między teologią i historią, która zapewne nigdy nie zostanie rozstrzygnięta raz na zawsze. Wielu wybitnych historyków Kościoła ${ }^{17}$ sytuuje badania w bezpośrednim kontekście teologicznym i broni takiego charakteru swojej pracy. Inni zaś, domagając się autonomii teologii, sytuują historię Kościoła tylko w ramach dyscyplin historycznych. Joseph Lortz, którego autorytet nie budzi wątpliwości, stwierdza zdecydowanie: „Historia Kościoła jest teologią"18. Roger Aubert we wprowadzeniu do znanej w Polsce pięciotomowej Historii Kościota, która w oryginalnym tytule francuskim nosi miano „nowej”, pisał: „Nie mogą istnieć dwa rodzaje historii Kościoła - jedna inspirowana przez teologię, a druga nie. Jest tylko jedna historia Kościoła, prawdziwa, ta sama dla wszystkich, albowiem w istocie nie ma dwóch prawd: jednej - naukowej, a drugiej - religijnej. Wszystko to, co jest prawdą naukowo dowiedzioną, jest prawdą bezwarunkową i nie budzącą zastrzeżeń, która jako taka obowiązuje zarówno katolików, jak i niekatolików, a zatem nie może się wykluczać wzajemnie z prawdą religijną, to znaczy z tym, co dane przez wiarę - jeśli uznajemy, że prawda religijna

17 Nie podzielam zdania tych historyków, którzy opowiadają się za his torią chrześcijaństwa, a nie za historią Kościoła, jak czyni na przykład Jerzy Kłoczowski i jego szkoła historyczna, ponieważ to Kościół jest podmiotem dziejów, a nie chrześcijaństwo, które należy raczej widzieć jako efekt działania Kościoła oparty na ideach, które głosi.

18 J. Lortz, Geschichte der Kirche in ideengeschichtlicher Betrachtung, t. 1: Altertum und Mittelalter, Münster 1962 (Cinisello Balsamo 1988, s. 8). 
jest tak samo w pełni prawdą"19. Hubert Jedin przyjmuje, że historia Kościoła jest teologią i historią, chociaż większy akcent kładzie na teologię, widząc w niej zarówno perspektywę organizującą badania historyczne, jak i kryterium weryfikujące ich wyniki ${ }^{20}$.

Dla poznania racji dwóch stron bardzo pouczająca może być korespondencja między Hubertem Jedinem i włoskim historykiem Kościoła z Uniwersytetu Laterańskiego w Rzymie, jakim był Michele Maccarone. 16 listopada 1975 roku Jedin pisał: „Historia Kościoła nie może być zrozumiana adekwatnie w swojej całości, jeśli nie uzna się, że Kościół ma boskie pochodzenie i jeśli oddziela się ją od teologii, jak czyni Conzemius w swoim artykule ${ }^{21}$, w zdecydowanej polemice przeciw koncepcji mojej i Iserloha. Badacz niewierzący może oczywiście z powodzeniem badać poszczególne kwestie z dziejów Kościoła - miało to miejsce dość często i nikt nie może i nie chce tego negować, ale skoro tylko podejmuje się wielkie i powiązane ze sobą zagadnienia zachodzi potrzeba osobistej relacji z przedmiotem historii Kościoła, a ściślej z pojęciem Kościoła zakorzenionym tylko w wierze i w teologii wierzącej. Jeśli idzie się, jak Conzemius, za skutkami wywartymi przez Jezusa Chrystusa w dziejach ludzkości, jeśli pogłębia się to wszystko, co odwołuje się do Niego (aż do najbardziej absurdalnych sekt), jest możliwa «historia chrześcijaństwa», ale nie historia Kościoła. Podtrzymuję więc moje przekonanie, że historia Kościoła jest teologią i historią. W relacji do Duchesne'a to oznacza: Duchesne ma rację, jeśli przyjmuje stosowanie bez zastrzeżeń metody historycznej; nie ma racji, jeśli całkowicie oddziela historię Kościoła od teologii. Dzisiaj nie podzielamy już wszystkich jego przekonań. Profesor, który wykłada historię Kościoła kandydatom do kapłaństwa, nie może uprawiać apologetyki, tak jak została ona odrzucona także przez Paschiniego, musi jednak uwypuklić, że historia Kościoła jest działaniem Bożym w procesie zbawienia,

19 R. Aubert, Wprowadzenie, [w:] J. Daniélou, H. I. Marrou, Historia Kościoła, t. 1: Od początków do roku 600, tłum. M. Tarnowska, Warszawa 1986, s. 5.

20 Por. H. Jedin, Chiesa della fede. Chiesa della storia, Brescia 1972, s. 51-65.

21 Conzemius, Kirchengeschichte als nichttheologische Disziplin, „Tübinger Theologische Quartalschrift” 155 (1975), s. 187-197. 
aby przekazać swoim studentom właściwe pojęcie Kościoła; musi nauczać w sposób «eklezjologiczny»".

27 listopada tego samego roku Maccarone odpowiadał: „Zerbi, Capitani i ja nie odmawialiśmy Miccoliemu (teraz, niestety, ateiście) prawomocności uprawiania historii Kościoła (to jest bowiem jego «historia religijna»), ale kwestionowaliśmy sposób, w jaki ją uprawiał, wybiórczy i oparty na odrzucaniu a priori istotnych elementów w historii Kościoła. Jeśli byłby to uwzględnił, mógłby uprawiać prawomocną i znaczącą historię Kościoła. Nie było konieczne, aby wychodził z założenia, że historia Kościoła jest «teologią», czy też, według twojej formuły, «teologią i historią», aby odmówić mu prawomocności uprawiania historii Kościoła i odsunąć go do historii chrześcijaństwa. Mamy bliskie przykłady, jak choćby Capitaniego, któremu nie można odmówić tytułu historyka Kościoła. Ze strony historyka Kościoła ważne jest uznanie, że w historii Kościoła jest także teologia, nie tylko historia ludzkiej instytucji - ale metodą pozostaje metoda historyczna luminis rationis, a nie metoda, którą powinien posługiwać się teolog, który wychodzi z objawienia. Dlatego uważam, że historia Kościoła nie jest «eklezjologią historyczną». Według mnie jest to istotne rozróżnienie między boską ekonomią Starego Testamentu, gdzie jest te okracja, to znaczy bezpośrednia interwencja Boga w historii pewnego narodu i jest historia salutis, oraz Nowym Testamentem, gdzie jest Kościół instytucja ludzka, której dzieje zależą od ludzi, przyznając Bogu tylko asystencję negatywną («non prevalebunt»)"22.

Historyk Kościoła przyjmuje od teologii przedmiot swoich badań, którym jest wzrost w czasie i przestrzeni Kościoła, założonego przez Jezusa Chrystusa. Materią dla jego badań jest Mistyczne Ciało Chrystusa, które jest czymś boskim i jest przedmiotem wiary.

22 Korespondencję wydał Mario Sensi w pracy: Monsignor Michele Maccarone e la Scuola storica lateranense, „Lateranum” 69 (2003), s. 343-400. Różne aspekty tej problematyki i jej reperkusje w badaniach dziejów Kościoła można poznać w oparciu o studia zebrane w: Qué es la historia de la Iglesia. Actas del XVI simposio international de teología de la Universidad de Navarra, eds. J. I. Saranyana, E. de la Lama, M. Lluch Baixauli, Pamplona 1996. 
Różni się więc od historyka religii, który traktuje Kościól jako jedną z wielu instytucji ludzkich i z tego wynika, jak napisał Jedin, że „historia Kościoła nie może być zrozumiana w swojej całości, jeśli nie uzna się Kościoła jako pochodzącego od Boga i jeśli oddziela się go od teologii"23. Aspekt teologiczny dotyczy jednak tylko jego boskiego początku, będącego dziełem Jezusa Chrystusa, jego struktury hierarchicznej i sakramentalnej, na której oparł go Jezus, i asystencji Ducha Świętego obiecanego uczniom przez Jezusa.

\section{DOJRZEWANIE HISTORIOGRAFII KOŚCIELNEJ}

Ojcem historiografii kościelnej jest Euzebiusz z Cezarei († 340). Jego Historia kościelna, będąca dokumentacją historyczną rozwoju pierwotnego Kościoła, dzieli się na dziesięć ksiąg. W pierwszej pokazuje, że ekonomia zbawienia ma początek w Jezusie Chrystusie, założycielu Kościoła. Nazywa on historią świętego i boskiego cesarstwa plan zbawienia, który urzeczywistnia się w Jezusie Chrystusie, aby doprowadzić do odnowy to wszystko, co zostało stworzone w niebie i na ziemi. Dlatego w pierwszym rozdziale Historii kościelnej Euzebiusz podkreśla: „Zacznę zaś nie od czego innego, lecz najpierw od ekonomii dotyczącej Zbawiciela i Pana naszego Jezusa Chrystusa Bożego Pomazańca" ${ }^{24}$. W języku greckich ojców Kościoła e k on o mia oznacza misję Jezusa Chrystusa wypełnioną przez przyjęcie człowieczeństwa, czyli całe Jego działanie zbawcze. Ekonomia, którą ojcowie łacińscy wyrażają słowem administratio, zajmuje się ludzkim aspektem Chrystusa i ma początek we wcieleniu; nie zajmuje się natomiast wprost aspektem boskim, który jest przedmiotem teologii. Historia Kościoła ma jednak do czynienia także z elementami niezmiennymi, jak tajemnica osoby i boskiej natury Jezusa Chrystusa. Wynika z tego szczególny charakter historii Kościoła - dyscypliny, która sytuuje się na szerokim polu teologii. Ponieważ Euzebiusz zajmuje się królestwem Chrystusa na ziemi,

23 H. Jedin, Introduzione alla storia della Chiesa, Brescia 1979, s. 35.

24 Euzebiusz z Cezarei, Historia kościelna $(1,1,2)$, tłum. A. Caba na podstawie tłumaczenia A. Lisieckiego, Kraków 2013, s. 17 (Źródła Myśli Teologicznej, 70). 
drogą zbawienia, jego dziejami, jego Historia kościelna jest kontynuacją Dziejów Apostolskich, będących pierwszym udokumentowanym opowiadaniem o „wspaniałych dziełach Bożych” wypełnionych w dziejach. Dlatego właśnie po opowiedzeniu w drugiej księdze historii pierwotnego Kościoła, od epoki apostolskiej aż do wojny żydowskiej (lata 65-66), podejmuje on zagadnienie następstwa biskupów jako kontynuatorów przepowiadania apostolskiego, biskupów zajmujących najbardziej prestiżowe stolice na Wschodzie: Jerozolimę, Antiochię i Aleksandrię. Dla Zachodu zostaje uwzględniony tylko Kościół rzymski (księgi III-V).

Rufin z Akwilei († 410) na prośbę Chromacjusza, biskupa Akwilei, przetłumaczył z greckiego na łacinę Historię kościelnq Euzebiusza z Cezarei, dokonując w niej pewnego przesunięcia akcentów. Zamierzeniem Rufina było nie tyle opowiedzenie o faktach samych w sobie, ile raczej pokazanie stopniowego utrwalania się królestwa Bożego.

Do pojęć opatrzności i łaski, obecnych już w historiografii Euzebiusza, św. Augustyn (354-430), biskup Hippony dodał przeciwstawienie „dwóch państw”. Stanowi ono swoistą zasadę dialektyczną, która pozwala na dokonanie w historii rozróżnienia między Kościołem i nie-Kościołem, między wybranymi i potępionymi. Augustyn identyfikuje w całych dziejach ludzkich, będących jakby wielką wędrówką, dwa państwa, które w czasie żyją, splatając się ze sobą, ale na końcu czasu zostaną definitywnie i na zawsze rozdzielone. Są to państwo Boże i państwo ziemskie zbudowane przez dwie różne miłości - miłość Boga i miłość siebie: „Dwie miłości więc powołały dwa państwa: miłość własna, posunięta aż do pogardy Boga, powołała państwo ziemskie; miłość Boga zaś, posunięta aż do pogardzenia sobą, powołała państwo niebieskie"25.

Dwa państwa mają wspólną tkankę dziejową, podczas gdy się rozwijają, ale na końcu ukażą się w tym, czym są rzeczywiście, rozdzielając się w sposób ostateczny i trwały. Na mocy tego dualizmu augustyńskiego dzieje nie są już prostym następowaniem po sobie

25 Augustyn De civitate Dei 14, 28 - tłum. pol.: O państwie Bożym przeciw poganom ksiag XXII, tłum. W. Kornatowski, t. 2, Warszawa 1977, s. 162. 
panowań, wojen, pasji, ale odzwierciedla się w nich postęp sprawy Bożej (causa Dei), o którą zmaga się pielgrzymujące państwo niebieskie w łonie państwa ziemskiego. Ksiądz Czesław S. Bartnik tak podsumowuje wizję św. Augustyna: „Pośród największych przeciwieństw i walk wszelkie nurty historyczne biegną, zwłaszcza dzięki Jezusowi Chrystusowi, ku Społeczności Bożej i, tutaj oczyściwszy się, osiągnąwszy udoskonalenie, przechodzą w Niebieskie Jeruzalem"26.

Wpracowane przez ojców Kościoła podstawy historiografii kościelnej przetrwały na Zachodzie właściwie aż do początków XIX wieku. Decydujące miejsce mieli w niej zapewnione papieże i biskupi. Dopiero Gabriel Le Bras zakwestionował ten odgórny sposób uprawiania historii, proponując sposób oddolny w ramach nowej szkoły, której sztandarowym wyrazem i organem stało się pismo „Annales”, którego tytuł stanowi na ogół również nazwę wypracowanego modelu uprawiania historiii ${ }^{27}$. Centrum badań zostało przeniesione z poziomu doktryn na poziom wspólnot o szerokim zasięgu, a nawet na poziom mas, mających na ogół charakter anonimowy. W ten sposób, szczególnie po II soborze watykańskim, uprawianie historii Kościoła według takiego modelu metodologicznego wniosło duży wkład w utrwalanie wizji Kościoła jako nowego Ludu Bożego - ludu mesjańskiego, którego Głową jest Chrystus ${ }^{28}$, podczas gdy hierarchia jest widziana w perspektywie służby pełnionej w ramach i na rzecz wiernych ${ }^{29}$.

Ze względu na dalsze wywody trzeba $\mathrm{w}$ tym miejscu zauważyć, że Jezus Chrystus obiecał pełną prawdę swojemu Kościołowi i Kościół katolicki obiektywnie tę prawdę posiada. Kościół katolicki jest jedynym, który mimo rozmaitych upadków i rozłamów

26 C. S. Bartnik, Historia ludzka i Chrystus, s. 198.

27 Por. J. Kłoczowski, Chrześcijaństwo i historia, Kraków 1990, s. 31-44; S. Lazar, Socjologia religii w ujęciu Gabriela Le Brasa, [w:] Christianitas et cultura Europae. Księga Jubileuszowa Profesora Jerzego Kłoczowskiego, red. H. Gapski, cz. 1, Lublin 1998, s. 765-770.

28 Por. II Sobór Watykański, konst. Lumen gentium, 9.

29 Warto prześledzić, w jaki sposób historiografia kościelna jest zależna od eklezjologii, a także w jaki sposób na nią wpływa. 
pozostał wierny temu wszystkiemu, co jest istotne na linii rozwoju zapoczątkowanego przez Chrystusa i apostołów. Nie oznacza to, że w Kościele katolickim dziedzictwo wiary zostało już wyrażone w sposób całkowity i ostateczny, szeroki i wolny, a w jeszcze mniejszym stopniu oznacza, że to dziedzictwo zostało subiektywnie przyjęte w sposób doskonały. Historia Kościoła dowodzi czegoś przeciwnego.

Jako dyscyplina naukowa historia Kościoła jest nauką, a więc jest poszukiwaniem i badaniem. Niezliczone są dziedziny i zagadnienia, którymi może się zajmować. To, czym się zajmuje, często jest zależne od pojawiających się okoliczności, na przykład przeżywanej rocznicy, a nierzadko zależy nawet od przypadku, jakim jest na przykład poszukiwanie tematu rozprawy akademickiej bądź znalezienie jakichś ciekawych dokumentów w archiwum parafialnym czy diecezjalnym. Znakomity włoski historyk Kościoła Giuseppe De Luca $(\dagger 1962)^{30}$ w czasie przemówienia zamykającego sympozjum włoskich archiwistów kościelnych, które odbyło się w dniach 5-8 listopada 1957 roku, mówił: „Rozumiem doskonale, że biskup powinien mieć swojego sędziego w trybunale, rozumiem, że biskup powinien mieć swoich profesorów w seminarium, ale nie rozumiem, absolutnie nie rozumiem, jak biskup może nie mieć swojego archiwisty w archiwum”. Stwierdziwszy, że „kapłan oddelegowany do archiwum, ale jedynie do archiwum, nie jest luksusem - jest koniecznością" na rzecz cywilizacji chrześcijańskiej, napominał uczestników sympozjum: „Nie chciałbym zachęcać was do dyletantyzmu, który jest utrwalonym nieszczęściem nas, kapłanów, w dziejach”. Zachęcał: „niech wasze studium, archiwum diecezji, parafii, bractwa, będą dla was dodatkiem do świątyni, przedłużeniem kościoła; [archiwum] było uzupełnieniem parafii dla Muratoriego, uzupełnieniem klasztoru dla Mabillona”. Podkreśliwszy, że „archiwum w strukturze kościelnej jest tym, czym pamięć jest w naszej strukturze psychologicznej”, i że „jak bez pamięci nie ma inteligencji,

30 Por. Don Giuseppe De Luca e la cultura italiana del Novecento. Atti del convegno nel centenario della nascita, Roma 22-24 ottobre 1998, a cura di P. Vian, Roma 2001. 
tak nie może być biskupa bez jego archiwum", kończył, wyznaczając kierunek nowego nurtu badawczego: „[Istnieje] inna historia, jak najbardziej przedziwna, ale tak samo pokorna: historia jakiegoś zaścianka, historia jakiegoś kościółka, historia jakiejś miejscowości, historia jakiegoś miasteczka, historia Kościoła w małych wiernych, w małych modlitwach. Powiem: historia pobożności - «zamilkł, a twarz jego była zasępiona...» (Dante, Czyściec 3, 45 $5^{31}$ )"32.

Każda wiedza musi mieć przedmiot, zdolność oraz narzędzia, aby go osiągnąć, i świadomość ograniczeń, gdyż każda wiedza ludzka jest poddana wewnętrznym ograniczeniom. Poznanie osiągane za pośrednictwem intelektu nie może być uważane za ostateczne. Nie posiadamy niczego w sposób ostateczny - posiadamy w sposób, który podlega doskonaleniu i to doskonalenie powinno być stale kontynuowane. W wypadku historii chodzi o dziedzinę, „która jest właściwa dla esprit de finesse, w którym dominuje świadomość istnienia różnych odcieni; nasza prawda pozostaje obca w stosunku do sumarycznego rygoryzmu ducha geometrycznego"33.

\section{DEONTOLOGIA HISTORYKA}

Narzędzia i metody badawcze, które określają jakość pracy historyka, są takie same dla wszystkich historyków, niezależnie od tego, jakimi dziedzinami rzeczywistości historycznej się zajmują. Deontologia zawodowa historyka opiera się na weryfikacji naukowej, jakiekolwiek byłyby jej założenia metodyczne.

Bardzo pouczające dla określenia deontologii historyka jest to, co podkreślił papież Leon XIII, dokonując przełomowego dzieła otwarcia archiwów watykańskich dla uczonych. W regulaminie z 1 maja 1884 roku wskazywał historykom katolickim jako drogę postępowania mądrość i prawość sumienia przedchrześcijańskiego, przy czym w krótkiej argumentacji na rzecz tego wskazania odwołał się do sfor-

31 Dante, Boska komedia, tłum. E. Porębowicz, Warszawa 1978, s. 196.

32 G. De Luca, Epilogo conclusivo al primo convegno di archivisti ecclesiastici, Roma, 8 novembre 1957, „Archiva Ecclesiae” 1 (1958), s. 134-146.

33 H. I. Marrou, La conoscenza storica, s. 225. 
mułowania, którego autorem jest Cyceron: „Primam esse historiae legem: ne quid falsi dicere audeat; deinde ne quid veri non audeat; ne qua suspicio gratiae sit in scribendo, ne qua simulatis" ${ }^{34}$. Historyk Kościoła musi jednak zwracać uwagę na rzecz zasadniczą, a mianowicie badając i odkrywając przypadkowe związki zachodzące między ważnymi wydarzeniami, powinien także dopuścić i uwzględnić czynniki transcendentne oddziałujące $\mathrm{w}$ wydarzeniach czy też mieć na względzie możliwość zjawisk nadzwyczajnych (np. cuda, doświadczenia mistyczne). Innymi słowy, historyk Kościoła powinien odznaczać się zmysłem prawd i wartości religijnych i duchowych, mimo że wykraczają poza jego bezpośrednią kompetencję, gdyż nie są przedmiotem badań opartych na metodzie historycznej, która ukierunkowuje badania naukowe wyłącznie na to, co może być zweryfikowane tylko po ludzku. Nie wystarczy więc przyjąć, że z przeszłości znamy tylko to, co jesteśmy w stanie zrozumieć na podstawie studium zachowanych dokumentów i że „historia jest prawdziwa w takiej mierze, w jakiej historykowi ukazują się ważne racje do uznania tego, co zrozumiał na podstawie dokumentów"35.

\section{NAUCZANIE HISTORII - METODA}

Jeśli przedmiot badania podejmowanego przez historyka Kościoła jest określany przez teologa, to historyk bada go za pomocą metody historycznej, różnej od metody teologicznej. Historia Kościoła ma uprawnioną odrębność, o której decyduje jej własna metoda badawcza. Przemiany zachodzące w rozumieniu tej metody nie mają większego znaczenia dla rozumienia tego zagadnienia.

Historia Kościoła bada wzrost Mistycznego Ciała Chrystusa, czyli żywego organizmu, który stopniowo rozwija się w czasie i przestrze$\mathrm{ni}^{36}$. Punktem wyjścia wiary chrześcijanina nie jest zbiór wypowie-

34 Leon XIII, Saepe numero considerantes (18 sierpnia 1883), „Acta Sanctae Sedis” 16 (1883-1884), s. 54 (całość dokumentu s. 49-57).

35 H. I. Marrou, La conoscenza storica, s. 235.

36 Na temat wzrostu (postępu) Kościoła w dziejach por. Ch. Journet, Le progrès de l'Église dans le temps, „Angelicum” 43 (1966), s. 3-20. 
dzi doktrynalnych, ale przede wszystkim osoba Jezusa Chrystusa, którego przyjmuje się przez wiarę, będącą bardzo specyficznym sposobem przyjęcia Go, oraz łączy się z Nim wewnętrznie, mając na względzie osiągnięcie osobistej przemiany, którą Chrystus ukazuje i urzeczywistnia w człowieku przez łaskę. Gdy to, co Boskie, w osobie Jezusa Chrystusa weszło w świat, nie zniszczyło kategorii naturalnego bytu i stawania się, ale im się poddało. Ciało mistyczne również w taki sam sposób rozwija się i wzrasta, ale, ponieważ nie jest wolne od chorób, doświadcza także regresu. Kościół Chrystusa nie jest rzeczywistością doskonałą pod każdym względem, ale ciągle potrzebuje oczyszczenia, prowadzącego do jego odnowy: „Ecclesia semper purificanda", jak stwierdza II Sobór Watykański w konstytucji Lumen gentium ( $\mathrm{nr} 8)^{37}$.

Mimo wszystko Kościół pozostał zawsze wierny swojej naturze, która wewnątrz jest niezmienna i trwała - to właśnie w odniesieniu do tego wnętrza zapewnił Chrystus swoich uczniów: „A bramy piekielne go nie przemoga" (Mt 16, 18). Jest to jeden z tych punktów, w których historia Kościoła staje się teologią, gdyż zakłada wiarę. Nie da się jednak wyprowadzić historii Kościoła z idei, nawet z tych objawionych; trzeba jej wytrwale i pokornie szukać w tym, co się dzieje, a więc w wydarzeniach, których podmiotem są zarówno pojedynczy wierni, jak i rozmaite wspólnoty. Historia Kościoła jest równocześnie historią i teologią - zgadzam się w tym ujęciu z Jedinem. Stąd autonomia metody naukowej historyka, która - jak przypomniał II Sobór Watykański - nie może wywoływać kryzysu w Kościele ani w wierzącym, czyli „z całkowitym zachowaniem praw osoby i wspólnoty, bądź to szczególnych, bądź uniwersalnych, w granicach dobra wspólnego" ${ }^{\prime 3}$.

W badaniach historycznych trzeba, między innymi, mieć odwagę intelektualną, by powiedzieć, że Kościół cierpi nie tylko z tego

37 Warto zwrócić uwagę, że II Sobór Watykański mówi o „odnowie” Kościoła (renovatio), a nie o jego „reformie”, jak na ogół się mówi w wypowiedziach na ten temat w teologii. Ostatni sobór nigdzie nie przyjął w znaczeniu dosłownym zasady: Ecclesia semper reformanda.

38 Por. II Sobór Watykański, konst. Gaudium et spes, 59. 
powodu, że jest prześladowany, ale także dlatego że jego dzieci są obciążone grzechami i rozmaitymi brakami. $Z$ tego powodu historia Kościoła jest pod pewnym względem także te ologią krzy$\dot{z}$ a. Wielokrotnie wracał do tego tematu papież Jan Paweł II w swoim nauczaniu o relacji obecnego Kościoła z przeszłością. Należy jednak podkreślić, że nigdy nie traktował tej kwestii autonomicznie - zawsze widział ją w ścisłej relacji z teologią świętości, gdyż tylko w ten sposób nabiera ona właściwego znaczenia i zachowuje ciągle aktualność w życiu Kościoła. Ogłaszając Jubileusz Roku 200o, w bulli Incarnationis misterium Jan Paweł II pisał: „Historia Kościoła jest historią świętości. Nowy Testament z mocą potwierdza tę cechę wyróżniającą ochrzczonych: są oni «święci» w takiej mierze, w jakiej odrywając się od świata podległego Złemu oddają się kultowi jedynego i prawdziwego Boga. Istotnie, świętość ta ujawnia się w życiu licznych świętych i błogosławionych, uznanych przez Kościół, a także w życiu ogromnej rzeszy bezimiennych mężczyzn i kobiet, których zliczyć nie sposób (por. Ap 7, 9). Ich życie potwierdza prawdę Ewangelii i daje światu widzialne świadectwo, że doskonałość jest możliwa. Trzeba jednak przyznać, że historia odnotowuje także niemało faktów, które z chrześcijańskiego punktu widzenia stanowią antyświadectwo. Ze względu na więź, która w Ciele mistycznym łączy nas z innymi, my wszyscy, choć nie ponosimy osobistej odpowiedzialności i nie pragniemy zastępować sądu Boga, który sam tylko zna ludzkie serca, dźwigamy ciężar błędów i win tych, którzy byli przed nami. Ale i my sami, synowie Kościoła, zgrzeszyliśmy, i dlatego oblicze Oblubienicy Chrystusa nie może jaśnieć pełnią blasku. Nasz grzech nie pozwolił Duchowi Świętemu działać w sercach wielu ludzi. Przez nasz brak wiary wielu pogrążyło się w zobojętnieniu i oddaliło od prawdziwego spotkania z Chrystusem" (nr 11).

Należy ponadto sprecyzować, że w celu właściwego wyprowadzania wniosków z badań historycznych oraz promowania poprawnego pojęcia Kościoła trzeba wyeliminować ciągle powracające w różnych wypowiedziach fałszywe rozróżnienie między „Kościołem idealnym” i „Kościołem faktycznym” - istnieje tylko jeden realny Kościół, to znaczy Kościół jako instytucja Boska i ludzka zarazem, 
która jest rzeczywistością historyczną. Kościół niewidzialny, który można uchwycić tylko przez wiarę, jest równocześnie widzialny i doświadczany historycznie. Obiektywna świętość Kościoła nie wyklucza ponadto grzechu członków Kościoła, zarówno u świeckich, jak i u pasterzy - grzech nie może pomniejszyć jedynej, danej przez Boga świętości Kościoła. Jesteśmy przekonani, że to, co dokonuje się w czasie, a więc konkretne wydarzenia, jest Boskie - Bóg jest Panem dziejów, Jego wola zbawcza kieruje światem, ale żeby ten plan osiągnął wypełnienie, Bóg może posłużyć się także błędami ludzi, dopuszczając je w swojej opatrzności.

Nauczanie historii Kościoła oznacza niewątpliwie prowadzenie do uświadomienia bogactwa i prawdy wiary katolickiej, która nie tylko zadowoliła intelektualnie wielką liczbę wyjątkowych ludzi, bardzo różniących się między sobą, należących do wszystkich czasów i wszystkich miejsc, ale także skłaniała ich do niezwykłych działań na wszystkich polach życia ducha. Nie można, oczywiście, zapominać o masach i o najdrobniejszych miejscach, w których ta prawda wywierała swoje twórcze skutki, dokonując przemiany obyczajów przez wskazanie człowiekowi właściwego celu, do którego powinien kierować się w dokonywanych wyborach. Takie ujęcie będzie stanowić autentyczną „apologię” Kościoła i będzie ukazywać pozytywnie jego miejsce w dziejach ludzkich. Nie oznacza to, że trzeba jednostronnie wywyższać przeszłość Kościoła i pesymistycznie patrzeć na teraźniejszość. Oznacza to po prostu, że trzeba mierzyć się z brakami i błędami, które popełnili i popełniają ludzie Kościoła, widząc w nich „ranę” zadawaną Kościołowi. Idąc za wezwaniem papieża Jana Pawła II, trzeba zmierzać stale do „oczyszczania pamięci”, odważnie i prawdziwie przedstawiając braki, mając w tym na względzie wyprowadzenie z nich jakiejś wyraźnej przestrogi na dziś i jutro. Tylko postępując zgodnie z tym założeniem, możemy oczekiwać od przeciwników większej ufności, gdy będziemy mówili o stronach pozytywnych Kościoła ${ }^{39}$.

39 Por. Międzynarodowa Komisja Teologiczna, Pamięć i pojednanie. Kościót i winy przeszłości, tłum. J. Królikowski, Kraków 2000. 


\section{TROSKA O ŹRÓDŁA}

Badanie i nauczanie historii Kościoła ma podwójny cel: poprawnie przekazywać wyniki badań nad minionymi dziejami - czyni się to, posługując się źródłami i historiografią - oraz wytrwale zachęcać do dalszych badań, najpierw studentów, ale także wszystkich, którzy są zainteresowani - a powinni być - dziejami wspólnoty, do której zostali włączeni przez chrzest. Chodzi o wędrówkę formacyjną, w której pierwszą rzeczą, nad którą trzeba pracować, jest poznanie dokumentów, czyli źródeł, z tym wszystkim, co miało związki z życiem i działalnością ludzi wierzących, a w ten sposób nawiązanie autentycznej więzi z przeszłością oraz ukształtowanie pamięci. Jak trafnie podkreślił Gerard Labuda, to „fakty źródłowe” stanowią "główne tworzywo «faktów historycznych»" ${ }^{40}$, czyli one są ośrodkiem poszukiwań historycznych.

Uznawszy, że historia Kościoła, jak każda dyscyplina, jest związana ze swymi ź ródła mi - pomniki, inskrypcje, dokumenty archiwalne i źródła literackie - na drugim miejscu należy uwzględnić, że w dalszym ciągu należy poszukiwać źródeł, mając na uwadze ich odkrycie i zabezpieczenie, oraz dokonywać ich krytyki i interpretacji. Badania historyczne potrzebują świadectw pisanych - świadectw rękopiśmiennych należy szukać we wszelkiego typu archiwach (niekiedy w bibliotekach), a świadectw drukowanych w bibliotekach. Historyk nie może improwizować i posługiwać się wiedzą nabytą „ze słyszenia" - musi nauczyć się poznawać źródła historyczne, mając na względzie ich naturę, genezę i oddziaływanie. Podstawowym działaniem poznawczym musi być heureza, czyli „odnalezienie, zebranie i opisanie wszystkiego, co ma stanowić podstawę źródłową dla odtwarzania dziejów" ${ }^{41}$, która pozostaje podstawowym aspektem poznania historycznego, a w sensie ogólniejszym także uczestniczenia w kulturze.

40 G. Labuda, O historykach. Kto jest kim w dziejopisarstwie polskim?, Poznań 2010, s. 30.

41 B. Kürbis, Cztery eseje o źródtoznawstwie, Poznań 2007, s. 108. 
Poszukiwaniu źródeł musi towarzyszyć analiza „bibliografii”. Przystępując do badania jakiegoś zagadnienia, trzeba zapoznać się z tym, co zostało na ten temat już napisane. Pozwala to, z jednej strony, oszczędzić czas, unikając powtarzania tego, co inni już udostępnili, a z drugiej strony pokazuje, których obszarów rzeczywistości jeszcze nie uwzględniono, a których zbadanie będzie mogło twórczo ubogacić osiągniętą wcześniej wiedzę.

W kontekście troski o źródła warto zwrócić uwagę na jeszcze jeden problem, który często bywa zapominany, a mianowicie na potrzebę coraz szerszego udostępniania źródeł, w tym także przygotowania edycji najważniejszych spośród nich. Dla uzasadnienia tej potrzeby przytoczę wypowiedź Brygidy Kürbis - jest to wypowiedź tym ważniejsza, że jej autorka w swoich badaniach historycznych wiele uwagi poświęciła właśnie opracowywaniu źródeł i ich analizie, niejednokrotnie wręcz przełomowej dla poznania historii Polski. Ze znawstwem popartym osobistym doświadczeniem tak więc pisze: „Nie tylko wielkie syntezy i skrupulatne prace analityczne, lecz także edycje tekstów i źródeł świadczą o poziomie nauki na danym etapie. Im rzetelniej słowo pisane i stan jego aktualnego poznania zostają przekazane do publicznego użytku, tym lepiej dla postępu nauki. Tym też lepszą szansę ma transmisja tych wyników do szerszej publiczności. Warto również na rolę dobrych edycji spojrzeć z perspektywy kultury narodowej. Kultura narodowa polega nie tylko na dorobku twórczym narodu, lecz także na pielęgnowaniu tego dorobku i przekazywaniu go kolejnym pokoleniom. Właśnie sztuka edytorska służy temu celowi zupełnie tak samo, jak znana wszystkim z tej funkcji konserwacja pomników sztuki. Mimo to sztukę edytorską traktuje się potocznie jako coś podrzędnego, a bywa też, że nie dostrzega się jej wcale" ${ }^{42}$. W pełni tę wypowiedź można odnieść do źródeł dotyczących historii Kościoła, zarówno Kościoła powszechnego, jak i każdego Kościoła lokalnego.

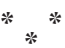

42 Tamże, s. 58. 
Zamiast zakończenia proponuję zapoznanie się z zasadami pisania o dziejach, które zaproponował na początku XIX wieku Euzebiusz Słowacki (1773-1814) ${ }^{43}$, ojciec Juliusza, gdyż mimo upływu czasu zachowują aktualność i mogą przydać się także współczesnym historiografom:

\section{Opowiadanie dziejów, czyli historia}

1. Historia jest jednem z najważniejszych pism rodzajów. Nie może więc być rzeczą obojętną sposób jej pisania. Retoryka względem tegoż podać powinna przepisy.

2. Uważać 1. należy człowieka, który się temu rodzajowi pisania poświęca, czego od niego wymagać mamy prawo: Sine ira et studio, quorum causa procul habeo (Tacyt, Annales 1,1). Wymagajmy tedy, aby dziejopis był zawsze wiernym czcicielem i ogłosicielem prawdy, szczery i bezstronny; 2. aby miał dar zgłębiania rzeczy i dalekiego widzenia; 3. aby żadna namiętność nie mieszała pokoju jego duszy, aby miał rozsądek górujący nad imaginacją; 4. aby miał potrzebne wiadomości i materiały, aby albo był oczewistym świadkiem, albo zbierał i pomnażał z krytyką powieści i podania dawne.

3. Historia zawiera pospolicie już to opowiadanie szczególnych przypadków, okoliczności i zdarzeń, już to wyprowadza je z ich źrzódeł i przyczyn, tudzież bada skutków następnych. Zawierać także może rozmowy i mowy osób ukazanych na scenie, które miały lub mieć mogły, opisanie miejsc, krajów i okolic; uwagi nad zbiegiem zdarzeń, ich wpływem, oświeceniem i charakterem szczególnych osób i całych narodów - słowem, to wszystko, co może wystawić dokładny obraz czasu i osób, których dzieje piszemy.

4. Chociaż historia zawiera opis rozmaitych zdarzeń, wymagamy w niej jednak jedności celu i zupełnej doskonałości skończenia.

43 Por. Stownik biograficzny historii Polski, t. 2, pod red. J. Chodery, F. Kiryka, Wrocław-Warszawa-Kraków 2005, s. 1407-1408. 
5. W malowaniu charakterów osób potrzeba ustanowić dokładnie stopnień wpływu, jaki te osoby miały na okoliczności i zdarzenia, powody i sprężyny ich postępków.

6. Jako w piśmie filozoficznem wolno jest na wsparcie prawdy użyć historii, tak też historykowi nie jest wzbroniono czynić uwagi nad zdarzenie, które opisuje, byle by w tem oszczędny, nie wpadł w ton deklamacyjnej gadatliwości.

7. Dozwolone mu są zboczenia do opisów rzeczy i zdarzeń, które się tyczą rzeczy i zdarzeń, które się tyczą rzeczy pryncypialnych, byle by autor nie tracił nigdy z oczu rzeczy celniejszej.

8. Jeżeli historią wstęp jaki, czyli przedmowa poprzedza, ta powinna być stosowna do rzeczy i użyteczna, to jest obeznawać czytelnika bądź z osobami, bądź z okolicznościami poprzedniczemi.

9. Porządek w pisaniu dziejów zachowywany jest dwojaki: 1. czasu, 2. rzeczy. Korzyści pierwszego i drugiego.

10. Zalety stylu: jasność, żywość, zwięzłość i godność.

11. Największą stylu ozdobą jest malowidło obrazów ${ }^{44}$.

44 E. Słowacki, Dzieła, t. 2, Wilno 1826, s. 26-27. 
ROZDZIAE XI

米

\section{Studium teologii i apostolat w świetle doświadczenia duchowego i teologii św. Tomasza z Akwinu}

Żyjemy w czasach nowego i szerokiego zainteresowania teologią oraz rozwoju akademickich studiów teologicznych. Jest to niewątpliwy znak czasu, który ma swoich przychylnych interpretatorów, łączących z nim wiele nadziei na przyszłość. Inni jednak stają po przeciwnej stronie, sprzeciwiając się akademickim studiom teologii, o czym świadczy powracająca debata o statusie naukowym teologii oraz o obecności i znaczeniu wydziałów teologii na uniwersytetach. Z wdzięcznością przyjmujemy możliwość udziału, jako wykładowcy i badacze, w tym wielkim wydarzeniu najpierw w ramach Instytutu Teologicznego w Tarnowie, a następnie w wyrosłym z niego Wydziale Teologicznym Sekcja w Tarnowie w ramach Papieskiej Akademii Teologicznej w Krakowie, obecnie Uniwersytetu Papieskiego Jana Pawła II. Cieszymy się, że kolejne pokolenia studentów zgłębiają wiedzę teologiczną, by potem wykorzystywać ją w życiu i w pracy zawodowej, którą podejmują. Oczywiście, zarówno praca naukowo-dydaktyczna, jak i studiowanie nie są wolne od trudności, dylematów, a nawet niepokojów, których źródłem są pytania o przyszłość, o znaczenie studiowania dla przyszłego życia, o możliwości podjęcia pracy itd. Niepewność 
wzbudzana przez zawirowania polityczne i ekonomiczne zawsze miała negatywny wpływ na jakość prowadzonych badań i gorliwość studiowania w każdej dziedzinie nauki. Z tym większym niepokojem przyjmujemy ekstrawagancje wielu reform wprowadzanych w ramach szkolnictwa wyższego, w których zapomina się, że podstawą owocnych badań i studiowania są nie tylko nowoczesne sale wykładowe i pomoce dydaktyczne, ale kultura bycia, wytrwałość i ciągłość podejmowanego wysiłku, pracowitość uczonych i studentów, a także zwykła uczciwość. Jednym słowem, w nauce decydujące znaczenie ma etos, a problemem jest to, że żyjemy w czasach, w których kryzys etosu jest wyjątkowo widoczny, a jego negatywne skutki są odczuwane także w dziedzinie prowadzonych badań naukowych i dydaktyki akademickiej. Problematyczne jest nie tylko to, że nie chce się tego uznać, ale - co jest jeszcze ważniejsze nie proponuje się drogi prowadzącej do naprawy, która może być tylko jedna - „zrehabilitowanie cnoty”, jak ponad sto lat temu trafnie wyraził się Max Scheler ${ }^{1}$.

$\mathrm{Na}$ ten ważny problem zwracali uwagę bp Wiktor Skworc albo niekiedy jego delegaci w mszach oprawianych $\mathrm{z}$ okazji inauguracji kolejnych lat akademickich. Niestety, trzeba to zdecydowanie powiedzieć, krąg słuchaczy padających wówczas ważnych wypowiedzi był na ogół bardzo ograniczony, sprowadzający się do kilkunastu przedstawicieli kadry naukowo-dydaktycznej i do nielicznej grupy studentów, w większość reprezentujących tarnowski wydział teologiczny. Można to uznać za jeszcze jedną oznakę kryzysu, o którym mowa. Pojawia się wiele pytań dotyczących istniejącej sytuacji oraz bezwzględna konieczność sformułowania propozycji dotyczących wyjścia z tego impasu.

W tym miejscu, mając na względzie sformułowanie jakiejś zrównoważonej propozycji w odniesieniu do istniejącego stanu rzeczy, proponuję spojrzeć na św. Tomasza z Akwinu, niewątpliwie wyjątkowego uczonego, dla którego służba nauce stała się drogą do osiągnięcia wybitnej świętości. Jego postawa etyczna, która odzwierciedla się

$1 \quad$ M. Scheler, Zur Rehabilitierung der Tugend (1913), [w:] tegoż, Vom Umsturz der Welte. Abhandlungen und Aufsätze, Bern 1955, s. 15. 
wyraźnie w jego pismach, dostarcza wielu inspiracji, które każdemu uczonemu i studentowi - nie tylko studentowi teologii - mogą pokazać drogę prowadzącą do świętości, a nawet do mistyki, czyli do najpełniejszego udziału w dziejach, do jakiego może dojść człowiek. Szczególne znaczenie przykład Doktora Anielskiego ma dla każdego teologa, zarówno badacza, jak i studenta, gdyż, jak słusznie zauważył Karl Rahner, ,jego teologia jest jego życiem duchowym, a jego życie duchowe jest jego teologią"

\section{STUDIUM I ASCEZA}

Jeśli chce się uchwycić zasadniczą wartość życia Tomasza z Akwinu, pierwszorzędną rację, dzięki której nabiera znaczenia wzorczego i ponadczasowego, trzeba wejść w sferę rozumu, ale nie rozumu oderwanego od życia i zamkniętego w myśleniu abstrakcyjnym, ale ożywianego przez duchowość bogatą w naukę i w autentyczne życie osobowe, które jest najwznioślejszą realizacją człowieka prawdziwie „intelektualnego”, to znaczy człowieka konsekwentnie żyjącego prawdą poszukiwaną, przyjmowaną, pogłębianą, adorowaną, przekazywaną z wytrwałością i miłością oraz niewahającą się przyjąć cierpienia ze względu na jej zwycięstwo ${ }^{3}$.

Nie ulega wątpliwości, że Akwinata był intelektualistą wiernym swojemu powołaniu i swojemu geniuszowi, dzięki czemu był także wolny od dewiacji, które przeszkadzałyby w twórczym kształtowaniu się jego myślenia ${ }^{4}$. Linia jego życia jest wyjątkowo prosta i jednolita, chociaż nie brakuje w niej także tego, co nadzwyczajne, co naznaczone jest dynamizmem i co staje się przygodą. Na jego życie składa się studium, nauczanie, dyskutowanie, pisanie rozpraw,

2 K. Rahner, Meditationen zur Kirchenjahr, Leipzig 1967, s. 112.

3 Wśród najnowszych biografii Akwinaty na szczególną uwagę zasługują: J. A. Weisheipl, Tomasz z Akwinu. Życie, myśl i dzieło, tłum. C. Wesołowski, Poznań 1984; R. Spiazzi, San Tommaso d’Aquino. Biografia documentata, Bologna 1997; J. P. Torrell, Tomasz z Akwinu. Człowiek i dzieło, tłum. A. Kuryś, Kęty 2008.

4 Na temat specyfiki intelektualizmu Tomasza z Akwinu można znaleźć przenikliwe uwagi w: P. Rousselot, L'intellectualisme de saint Thomas, Paris 1924. 
kariera profesorska, a więc obejmuje ono to wszystko, z czym kojarzy się intelektualizm, który kultywuje wiedzę i pracuje nad jej rozpowszechnianiem. Gdy jednak usiłujemy sięgnąć w głąb Tomasza, starając się odkryć jego zmysł wewnętrzny, siłę poruszającą, tchnienie, które go ożywia, możemy z radością stwierdzić, że myśl Tomasza była rzeczywiście „żywa”, że była gorąca i pulsująca duchem kochającym, że nigdy nie poddała się naciskowi schematów, abstrakcji i rozróżnień, które mogą spłycić i spłaszczyć każdą myśl, zepchnąć ją do sceptycyzmu, postawić na granicy nicości.

Wraz z Tomaszem wielki intelekt przeszedł pośród ludzi, ale towarzyszyło mu równie wielkie serce. Jego geniusz był wierny jego osobowemu powołaniu i okazał się bogaty w wyjątkowe rezultaty, ponieważ należał do świętego. Myśl Akwinaty wpisuje się więc organicznie w porządek jego świętości, stanowiąc jej pierwszorzędne tworzywo. Autentyczna ascetyka myśli stanowiła podstawę wewnętrzną dla jego studium i dla jego nauczania oraz naznaczyła jego wędrówkę doskonałości. Można powiedzieć, że on sam zawarł w swoich pismach konieczne i wyraźnie wyodrębnione elementy do zbudowania ram intelektualnych jego biografii jako świętego. Studium - stwierdza Tomasz - zakłada konsekwentne odniesienie myślowe do przedmiotów, które są materiałem poznania ${ }^{5}$. Jest to jakby napięcie ducha w kierunku prawdy, poryw witalny, który rodzi się z pragnienia jej osiągnięcia oraz pobudza poświęcenie i wysiłek, aż do kontemplacji i do oglądania przedmiotu w duchu ubogaconym dojrzałą myślą. Proces poznania prawdy i życia, które jej odpowiada, można opisać, odwołując się do trzech zasadniczych momentów, które konstytuują afirmację duchową w ascetyce myśli:

- moment oczyszczenia, polegający na wewnętrznym uporządkowaniu władz, które kierują życiem duchowym;

- moment poszukiwania, będący wysiłkiem przyjęcia prawdy kochanej i intensywnie osiąganej;

- moment kon templacji, polegający na unifikacji wewnętrznej w spokojnym posiadaniu prawdy i hojnym dzieleniu się nią z innymi.

5 Tomasz z Akwinu, Summa theologiae, II-II q. 166 a. 1 [dalej: STh]. 
1. W pierwszym momencie chodzi o osiągnięcie spokoju w świecie wewnętrznym za pośrednictwem cnót moralnych, które uporządkowują namiętności wywołujące w duszy rozproszenia, gdy zwracają ją do tego, co interesuje zmysły, zaniedbując to, co może być zrozumiane. Trzeba ponadto ukształtować relacje zewnętrzne i podejmowane zajęcia w pokoju, aby wyeliminować naciski zewnętrzne wywierane na ducha, oddalające go od jego spokojnej wędrówki do tego, co prawdziwe ${ }^{6}$. Jest to cały wysiłek ascetyczny oczyszczenia wewnętrznego i uporządkowania zewnętrznego, mogący urzeczywistnić się tylko przez praktykę cnót, które pozwalają osiągnąć pokój i czystość 7 . Trzeba rozciągnąć na cały własny świat panowanie rozumu aż do tego stopnia, by w każdej sferze bytu zajaśniało światło racjonalności. Wtedy urzeczywistnia się życie w pięknie, przede wszystkim dzięki praktykowaniu czystości, która bardziej niż jakakolwiek inna cnota uzdalnia człowieka do rozwijania życia myśli, ponieważ porządkuje te namiętności, które w decydującym stopniu ograniczają ducha, wpychając go w sferę zmysłowości, aż do najgorszych aberracji zmysłowych ${ }^{8}$.

Jeśli przedmiotem studium jest sam Bóg szukany przez duszę ponad wszystkimi innymi stworzeniami jako cel ostateczny życia intelektualnego, pokrywający się z rozwijającym się poszukiwaniem prawdy, wtedy czystość jest konieczna w jeszcze większym stopniu, ponieważ uwalnia ona duszę od wszelkich nieuporządkowanych uczuć wiążących ją ze światem ziemskim. Taka czystość jest osiągana przez praktykowanie cnót i przyjęcie darów Ducha Świętego, które kształtują prawość woli oraz uporządkowują namiętności (roztropność, sprawiedliwość, dzielność, wstrzemięźliwość oraz cnoty z nimi powiązane: pobożność, odwaga, bojaźń Boża). Chodzi także o czystość myśli, która oświeca spojrzenie wewnętrzne usiłujące uwolnić się od mrocznych obrazów, które wiążą człowieka z rzeczywistościami zmysłowymi, zagrażając coraz bardziej właściwej wizji rzeczywistości duchowych, szczególnie Boga, którego - jak

\footnotetext{
Por. STh II-II q. 180 a. 2.

Tamże, ad 2.

Por. tamże, ad 3.
} 
mówił Dionizy Areopagita - nie możemy widzieć inaczej jak tylko „przez zasłonę". Do tej czystości dochodzi się dzięki darowi rozumu, który pozwala wniknąć w prawdę Bożą, przezwyciężając wszelkie ograniczenia ziemskie i zmysłowe, które zaciemniają wewnętrzny blask tej prawdy ${ }^{9}$.

Ze względu na kontemplację Boga i w wysiłku upodobnienia do Niego powinno się dokonywać stopniowego oczyszczenia i umocnienia cnót moralnych, zgodnie z procesem określonym już w starożytności przez Plotyna i Makrobiusza, a przejętym przez Akwinatę, dzięki któremu życie moralne może osiągnąć w mędrcu stopnień pełnej kontemplującej stałości, odzwierciedlający w sposób możliwy do osiągnięcia przez człowieka wieczny wzór wewnętrznego życia Boga. Są to „cnoty tych, które wznoszą się i zmierzają do podobieństwa Bożego - są to cnoty oczyszczające". Reprezentują one przekroczenie życia „ziemskiego", skierowanego do ziemi, i zdecydowane ukierunkowanie do bytu Bożego. Wtedy roztropność przekracza zdecydowanie to, co światowe, i kieruje każdą myśl do światła Bożego; wstrzemięźliwość zostawia na boku, na ile to możliwe dla natury, także rzeczy użyteczne dla ciała; dzielność pozwala osiągnąć stałość $\mathrm{w}$ wysiłku ascetycznym zmierzającym do zerwania z tym, co cielesne i zmysłowe, aby skierować się do tego, co duchowe; sprawiedliwość utrwala duszę w prawej wędrówce do doskonałości, którą obrało się za program życia. Po zrealizowaniu tej drogi ma się „cnoty tych, którzy osiągnęli podobieństwo Boże - nazywają się one cnotami duszy już oczyszczonej". Podejmują one czyny w spokojnym klimacie już całkowicie przenikniętym przez świętość Bożą. Wtedy roztropność nie myśli, nie oddycha i nie widzi niczego innego oprócz tego, co boskie; wstrzemięźliwość ignoruje poruszenia woli skierowane do tego, co ziemskie; dzielność nie zna poruszeń namiętności; sprawiedliwość łączy trwałym paktem duszę z myślą Bożą w doskonałym naśladowaniu jej idei wzorczej, którą jest Słowo ${ }^{10}$.

Wraz z urzeczywistnianiem się tego procesu moralnego zostają uduchowione i coraz bardziej zuniwersalizowane pojęcia myśli,

9 Por. STh II-II q. 8 a. 7.

10 Por. STh I-II q. 61 a. 5. 
wydobywając z mrocznej materii żywe odczucie rzeczy - for mę, która jest odbiciem i dotknięciem tego, co Boskie. To odczucie przekracza rzeczy stworzone aż do osiągnięcia rzeczywistości nieskończonej, w której myśl spoczywa i raduje się posiadaniem światła nieśmiertelnego, a w odsłoniętym niebie cieszy się czystością widzenia.

Tomasz urzeczywistnił $\mathrm{w}$ sobie ten proces oczyszczenia wewnętrznego, zarówno moralnego, jak i intelektualnego, wypracowując harmonijny kompleks cnót. W swoim działaniu jawi się jako człowiek w pełni zrealizowany, dojrzały pod każdym względem. Wilhelm z Tocco, jego biograf, zapisał, że był on „najpokorniejszy w myśleniu o sobie, najczystszy w ciele i w duszy, pobożny w modlitwie i przewidujący w udzielaniu rad, łagodny w rozmowie, gorliwy $\mathrm{w}$ miłości, jasny $\mathrm{w}$ rozumowaniu, przenikliwy w myśleniu, pewny w osądzaniu, stały w pamiętaniu, niemal codziennie podniesiony ponad zmysły, lekceważący rzeczy doczesne, tak że jako człowiek wydawał się posiadać sprawności wszystkich cnót"11.

Uporządkowane i spokojne korzystanie z posiadanego geniuszu było możliwe dla Tomasza, ponieważ zawierało się w ramach i pod kierunkiem życia moralnego całkowicie zdyscyplinowanego. Praktykował on pokorę, która jest odpowiednim widzeniem siebie, a tym samym staje się także hamulcem dla ducha dążącego do samowywyższenia. Wyznał serdecznie: „Dziękuję Panu, ponieważ nigdy nie doświadczył mnie poruszeniem próżnej chwały z powodu mojej wiedzy, z powodu mojej pozycji nauczyciela, z powodu jakiegoś sukcesu szkolnego - jeśli niespodziewanie pojawiało się ono u mnie, szybko je oddalałem sądem rozumu". Tomasz był przekonany, że cała wiedza, jak każdy inny dar, pochodzi od Boga, a więc nie była dla niego powodem wywyższania się i chlubienia się jak rzeczą własną. Dlatego kierował się pokornym przekonaniem o sobie w rozmowach z innymi, które zawsze były pełne słodyczy i łagodności. Biograf zanotował, że zawsze był człowiekiem „dostępnym”

11 Wilhelm z Tocco, Vita sancti Thomae Aquinatis, ed. D. M. Prümmer, St. Maximin 1924, s. 97 [dalej: Vita]. Do tej fundamentalnej biografii Tomasza z Akwinu odwołujemy się w niniejszym opracowaniu. 
dla innych. Nie żył na jakichś niebotycznych szczytach myśli, otoczony murami, które oddzielałyby go od ludzi i od świata. Nie uznawał się za człowieka wyższego od innych czy też sławnego. Jego słowo było łagodne, łatwe, radosne, pełne cichości. Traktował swoich braci i studentów serdecznie i uczciwie. Zależnie od okoliczności umiał się dla nich poświęcić, jak na przykład wtedy, gdy w Bolonii pewien brat, spotkawszy go w wirydarzu, a nie znając go, poprosił, aby mu towarzyszył w wyjściu do miasta, zgodnie z poleceniem przełożonego, aby w takiej sytuacji zabrać ze sobą pierwszego napotkanego brata. Tomasz wyszedł ze współbratem do miasta, towarzysząc mu mimo trudności spowodowanych niedyspozycją fizyczną i mimo wymówek słyszanych z powodu powolności. Gdy ludzie zauważyli Tomasza, otoczyli go tłumnie, aby oddać mu uszanowanie, a współbrat poprosił go o wybaczenie. Tomasz ograniczył się do stwierdzenia, że w życiu zakonnym najważniejsze jest posłuszeństwo. Innym razem, zaatakowany grubiańsko na uniwersytecie w Paryżu przez nowego, początkującego mistrza, przemilczał sprawę, by nie zawstydzać - jak później wyznał studentom - owego nowicjusza. Wobec nacisku braci jednak następnego dnia spokojnie zwrócił zainteresowanemu uwagę, że - pomijając prawdę jego nauczanie nie mogło być przyjęte, ponieważ było przeciwne nauce soboru, a potem cierpliwie zdołał przekonać go o błędzie. Mistrzowie, którzy temu wszystkiemu towarzyszyli, mogli podziwiać - jak podkreśla Wilhelm - jego spokój ducha i łagodność słowa, o co nie jest łatwo także w dysputach teologicznych.

Tomasz był przejrzyście czysty. Został on utwierdzony w czystości w czasie uwięzienia w zamku w Monte San Giovanni, gdy zdecydowanie, kawałkiem polana wyjętego z paleniska, zwrócił się przeciw kusicielce, którą jego bracia przyprowadzili do jego pokoju, aby złamać jego opór w stosunku do rodziny, która chciała go odwieść od pójścia za braćmi żebrzącymi. Po tym zwycięstwie ogarnęła go tajemnicza siła, która uczyniła go odpornym na ataki demona nieczystości. Od tamtego wydarzenia zachowywał pewien dystans w stosunku do osób odmiennej płci i dziwił się, że ludzie poświęcający się kontemplacji i nauce Bożej mogli tracić czas na rozmowy z kobietami poza przypadkami konieczności i rozmowy 
duchowej ${ }^{12}$. Jego kierownicy sumienia mogli poświadczyć, że nie było w nim nigdy żadnego przyzwolenia na poruszenia nieczyste. Reginald z Piperno, przyjaciel i spowiednik Tomasza, wysłuchawszy jego spowiedzi w bliskości śmierci, powiedział, że jego sumienie było czyste jak pięcioletniego dziecka. Tomasz zrozumiał, że do duszy grzesznej nie może wejść mądrość i dlatego, poświęciwszy się całkowicie sprawom Bożym, nie pozwolił się dotknąć przez żadną brzydotę. Jego wewnętrzna jasność, która czyniła go zdolnym do wielkich wizji i bogatych syntez myślowych, była owocem jego czystości. Z jego osoby promieniował blask i wyzwalał moc ducha, który miał siebie w świetle - jego dusza była pełna pokoju.

Wysoki, wręcz olbrzym, z mocnymi ramionami, o głębokim i przenikliwym spojrzeniu - ale równocześnie spokojnym i jasnym jak u dziecka wolnego od złości, z wielką głową, z karnacją koloru pszenicy - jak zanotował Wilhelm - delikatny i wrażliwy na ból, Tomasz promieniował dokoła siebie niewinnością połączoną z mocą charakterystyczną dla wzniosłej osobowości, która zwracała uwagę ludzi z powodu jego wyższości intelektualnej i moralnej. Geniusz spotkał się w nim i dogłębnie połączył z cnotą. Było to owocem osiągnięcia pełni człowieczeństwa, promieniującego fascynacją i żywotnością z powodu wewnętrznego poczucia bycia człowiekiem spełnionym.

Jego zażyłość z prawdą czyniła go człowiekiem prostym, jasnym, prawym, wolnym od dwuznaczności. Nie poddawał się złu i zwalczał wszelki fałsz. Utrzymywał, że raczej należy pozwolić, by upadł świat, niż dopuścić się choćby najmniejszego kłamstwa. Z trudnością przyjmował grzech drugiego człowieka i gdy stawał wobec faktu czyjejś winy, opłakiwał ją, jakby to była jego własna wina. Jako człowiek stały i zdecydowany w obronie prawdy zwalczał błędy, ale z powodu wielkoduszności nie ulegał łatwej pokusie wyolbrzymiania błędów i win innych. Widział rzeczy małe w ich małości, nie czyniąc z nich gór. Nie wtrącał się w sprawy innych ludzi. Nie zajmował się sprawami banalnymi - chciał czuć się wolny w dążeniu do prawdy

$12 \quad$ Vita, s. 75. 
uniwersalnej. Zajęty studiowaniem osiągnął taki poziom łagodności, który jest właściwy tylko wielkim myślicielom, którzy prostymi oczami widzą świat i życie, nie komplikują zbytnio rzeczy i spraw, by nie stracić żywotności i powagi. Promieniował więc nieustannie poczuciem radości duchowej. Umiał współczuć i rozumieć, umiał poświęcać się i dawać, dzieląc z innymi uczucia duchowe i rozmaite jałmużny, ze świętą bezinteresownością i bez zwracania uwagi na siebie, jak czynią ludzie przeciętni. Życie w prawdzie było w nim nieustannie ożywiane i zapalane przez miłość.

Nie był przywiązany ani do siebie, ani do rzeczy tego świata. Zdecydowanie odrzucał wszelkie godności i przywileje; z wielką pociechą przyjął doznane objawienie, że umrze jako pokorny zakonnik, którym zdecydował się zostać w młodości. Nie szukał stanowisk w swoim zakonie, uważając, że żadne inne miejsce niż to, które posiada, czyli miejsce uczonego i nauczyciela, nie będzie dla niego lepsze do szukania prawdy ${ }^{13}$. Czując się autentycznym oblubieńcem wiecznej mądrości, w najmniejszym stopniu nie wzdychał za tym, co zostawił w świecie, ponieważ wiedział, że w mądrości ma wszystkie prawdziwe i największe dobra, które może osiągnąć człowiek. Pewnego dnia podczas powrotu z wycieczki studenci zapytali go, czy nie chciałby posiadać Paryża, który w całym swym pięknie rozciągał się przed nimi. Odpowiedział, że gdyby posiadał miasto i nim rządził, to nie mógłby poświęcić się kontemplacji Boga i cieszyć się duchowo i dlatego bardziej od Paryża chciałby mieć w tej chwili do dyspozycji homilie św. Jana Chryzostoma do Ewangelii św. Mateusza. W tym pragnieniu okazał się prawdziwym uczonym, a także prawdziwym świętym.

Idąc w sposób pokorny i ubogi za Chrystusem, zachowując posty i inne dominikańskie praktyki pokutne, skupiony w sobie, wolny od rozproszeń, Tomasz pokazywał na co dzień, na czym polega otwieranie się na nadprzyrodzony wpływ darów łaski. Jego natura była bogata w dary fizyczne, intelektualne i moralne, ale przede wszystkim łaska Boża decydowała o jego osobowej jakości i wznio-

13 Tamże, s. 137. 
słości. Ze spotkania darów natury i łaski rodziła się jego bogata osobowość, która w dziedzinie intelektualnej zaprezentowała niespotykaną subtelność geniuszu, pewność w wydawanych ocenach, wzniosłość nauczania, jasność widzenia problemów, przenikliwość tajemnicy świata i Boga. Pod działaniem Ducha Świętego jego duch był oświecany i prowadzony do świętości prawdy, aż do wyraźnego dostrzegania w niej tajemnicy samego Boga. Dar rozumu kwitł w jego czystej duszy. Tylko w ten sposób można wyjaśnić wzniosłość i subtelność jego myśli i wypracowanych syntez. Osiągnąwszy harmonię wewnętrzną, mógł spodziewać się po studium i kontemplacji, przy pomocy Bożej, dobrych wyników.

2. Studium, podobnie jak poszukiwanie i wysiłek przyswojenia sobie prawdy, było drugim momentem rozwoju intelektualnego św. Tomasza. Jak aktywność duchowa, tak też studium domaga się dyscypliny, którą możemy określić jako pilno ść. Należy ona do grupy cnót związanych z wstrzemięźliwością jako siłą kierująca ruchem wewnętrznym dążącym do poznania ${ }^{14}$. Jest to cnota moralna. Jeśli poznanie prawdy jest związane $\mathrm{z}$ rozumem, a więc należy do cnót intelektualnych (wiedza, rozum, mądrość) i jest wspierane odpowiednimi darami nadprzyrodzonymi, to pragnienie wiedzy jest zawsze aktem woli, która musi być umacniana w prawości, zarówno jeśli chodzi o przedmioty poznania, jak sposób dostosowania do nich wysiłku intelektualnego. Tomasz stwierdza lapidarnie: „Intelligo enim quia volo et utor omnibus potentiis quia volo", to znaczy „rozumiem, ponieważ chcę"15. Poznanie domaga się więc interwencji cnoty, która reguluje ten wysiłek i go kontroluj $\mathrm{e}^{16}$, aby nie stał się aktem pychy, która zgubiła pierwszych ludzi i przeciwko której św. Piotr Damian rzucał gromy, ale jest natomiast prawą służbą prawdzie i jej kultywowaniem, nadającą sens życiu człowieka stworzonego na obraz Boży, czyli rozumnego i zdolnego do duchowego podniesienia się aż do harmonijnego

\footnotetext{
14 Por. STh II-II q. 166 a. 2.

15 Tomasz z Akwinu, De malo, q. 6 corp.

16 Por. STh II-II q. 166 a. 2 ad 2.
} 
wpisania się w rzeczywistość świata, a w końcu do utożsamiającego udziału w życiu samego Boga.

Dusza człowieka dąży więc do poznania, ale to dążenie naturalne musi być hamowane, aby zachowało wolność od wszelkiej przesady i od wszelkich dewiacji. Trzeba równocześnie uwzględniać, że ciało, zawsze będące ciężarem dla duszy, zmierza do uniknięcia wysiłku badawczego i trudu związanego z zajmowaniem się sprawą myślenia. Również myślenie ma to do siebie, że u człowieka wywołuje „ból”. Niełatwo samo przez się satysfakcjonuje człowieka. Jest ono naznaczone trudem, znużeniem, zmęczeniem, szczególnie jeśli natura podsuwa człowiekowi swoje atrakcje, jeśli odczuwa, że instynkty buntują się i sugerują zajęcie się czymś bardziej atrakcyjnym, że zachęcają do zabawy, wspierane przez rzeczywiste lub domniemane potrzeby fizjologiczne i psychiczne rozluźnienia się i zasmakowania w odpoczynku.

Inną formą tej tendencji jest pragnienie działania, skutecznego, intensywnego, dynamicznego, bardziej pociągającego i satysfakcjonującego niż zajęcia poznawcze i naukowe. Czyż dzisiaj nie jest to zjawisko nad wyraz widoczne? Niepohamowany aktywizm, bez uporządkowania racjonalnego, co więcej, często prezentowany jako pasja antyintelektualna, jak wykazał na przykład Huizinga ${ }^{17}$. Także w dziedzinie religijnej i apostolskiej wyraźnie widać pojawianie się takiej pokusy, a życie pokazuje, jak bardzo trudno jest ją odrzucić. Na brak jej zdecydowanego zwalczania ma wpływ ogólna sytuacja duchowa panująca w naszych czasach.

Zachodzi więc bardziej zdecydowana konieczność oparcia się pokusom zabawy i działania oraz trwania w pracy ducha $\mathrm{z}$ tą vehementia intentionis, która należy do samego pojęcia "studium”. Wtedy prawdziwa ascetyka studiowania, kierowanego cnotą pilności, z jednej strony będzie hamować nieuporządkowane pragnienie wiedzy, a z drugiej będzie koncentrować na tym, co istotne, oraz zapalać do gorliwego podjęcia osobistego zadania poszukiwacza i sługi prawdy ${ }^{18}$.

17 Por. J. Huizinga, Homo ludens. Zabawa jako źródto kultury, tłum. M. Kurecka, W. Wirpsza, Warszawa 1985.

18 Por. STh II-II q. 166 a. 2 ad 3. 
Wiedza sama z siebie jest rzeczywistą wartością ludzką i jest rzeczą dobrą. Nie należy ani się jej bać, ani nią straszyć. Kościół zawsze dowartościowywał wiedzę świecką i traktował ją z szacunkiem i przyjaźnią, a jeśli się wypowiadał negatywnie na jej temat, to było to zawsze spowodowane jej przewartościowaniem. Wiedza jest święta, jak święta jest prawda. Tylko drugorzędnie może stać się zła, przede wszystkim z racji konsekwencji, w które mogą zostać przez nią spowodowane w człowieku skłonnym do złego posługiwania się nawet rzeczami największymi i najpiękniejszymi. Wiedza może prowadzić do pychy (scientia inflat - mówi św. Paweł [1 Kor 8, 1]) lub też można posłużyć się wiedzą, aby grzeszyć. Jest tragedią człowieka, jeśli osiągnięta wiedza służy mu do tego, by więcej grzeszyć, chociaż wiedza sama z siebie wynosi człowieka i używa on do jej osiągnięcia tych samych sił, które Bóg złożył w nim i w naturze, aby je stopniowo odkrywał. Wystarczy pomyśleć o wielu współczesnych wynalazkach, a szczególnie o możliwym użyciu atomu. Człowiek może zniszczyć siebie, jeśli w jego sercu nie będzie królowała cnota.

Według Tomasza pragnienie wiedzy może więc być złe, jeśli ktoś studiuje, mając na względzie złe użycie zdobytej wiedzy. Taka sytuacja zachodzi na przykład wtedy, gdy ktoś studiuje, by być podziwianym, by pokazać swoją wielkość, by otrzymywać pochwały i aplauzy lub by zadośćuczynić jakimś złym pragnieniom. Studiowanie może być złe także z innych powodów, na przykład gdy bardziej niż materie godne lub bardziej odpowiednie woli się studiować materię mniej użyteczną i godną, nieprzystającą do własnego powołania (na przykład jeśli kapłan czytałby literaturę świecką ze szkodą dla studium objawienia i teologii), gdy bada się świat widzialny, ale po to, by odkryć w nim jakieś tajemne moce pozwalające panować nad tym, co stworzone, na przykład demony czy tak zwane dzisiaj "duchy”, ponieważ w ten sposób pobudza się zabobon. Studiowanie jest złe, jeśli osiąga się poznanie stworzenia bez ukierunkowania go do właściwego dla niego celu, to znaczy do Boga (jak dzieje się w wielu dziedzinach wiedzy i kultury, które zwalczają wszelkie instancje religijne i wszelki teocentryczny sens życia). Studiowanie jest złe w końcu wtedy, gdy szuka się wiedzy ambicjonalnie, nie licząc się realistycznie z możliwościami swoich zdolności intelektualnych, narażając się 
w ten sposób na niebezpieczeństwo popełnienia błędu wbrew napomnieniu biblijnego mędrca: „Nie szukaj tego, co jest za wysokie dla ciebie, i nie badaj tego, co ponad twe siły. [...] Rzeczami niepotrzebnymi nie zajmuj się wiele i w wielu dziełach jego nie bądź ciekawy. [...] Wielu też ludzi omyliło mniemanie ich i myśli ich w próżności zatrzymało" (Koh 3, 22.24.26) ${ }^{19}$.

Tylko poznanie najwyższej Prawdy jest dobrem człowieka dobrem wolnym od jakiegokolwiek braku i pewnym w najwyższym stopniu, udoskonala ono ducha i daje mu udział w szczęściu. Poznanie innych prawd może zawierać zalążki zła, jeśli pragnienie poznania rzeczy niższych nie jest włączone w porządek poznania Boga, który jest celem życia ludzkiego ${ }^{20}$. Owszem, jest prawdą jak mówił Dionizy Areopagita - że racjonalność, to znaczy bycie odpowiednie do prawdy, jest dobrem człowieka. Człowiek w swojej racjonalności jest podobny do Boga. Poznając, w najwyższym stopniu osiąga to upodobnienie. Mówił Arystoteles, że Bóg kocha tych, którzy czczą rozum, ponieważ jest to oddanie chwały Bogu, twórcy rozumu i pierwszej przyczyny każdego aktu poznawczego. Racjonalność sama z siebie nie czyni jednak człowieka dobrym. Domaga się ona od człowieka, który studiuje, odpowiedniej postawy moralnej, to znaczy takiej, która na pierwszym miejscu stawia osobistą prawość i świętość. Wiedza staje się dobra i prawa tylko w głębi serca; o jej dobroci i prawości nie decydują osiągnięte rezultaty poznawcze, ale jakość formacji duchowej.

Kościół katolicki nigdy więc nie potępił wiedzy, a zwłaszcza filozofii, nawet jeśli ostrzegał przed błędami, które są w niej możliwe i które niejednokrotnie były i są przez nią szerzone. Tomasz streścił w kilku zwartych zdaniach starą tradycję, którą reprezentowali zarówno greccy ojcowie Kościoła, począwszy od Klemensa Aleksandryjskiego, jak i ojcowie łacińscy. Napisał tak: „Nauka filozofii jako taka jest godna pochwały i zalecenia z powodu prawdy, którą filozofowie dzięki objawieniu Bożemu pojęli”. W tym stwierdzeniu odnosi się wprost do św. Augustyna, który pisał: „Tych

19 Por. STh II-II q. 167 a. 2.

20 Por. tamże, ad 1. 
natomiast, którzy nazywają się filozofami, zwłaszcza platoników, nie tylko nie należy się obawiać, ale od nich, jako od nieprawnych posiadaczy, należy rewindykować to, co przypadkiem powiedzieli prawdziwego i odpowiadającego naszej wierze na nasz pożytek" ${ }^{21}$. Tomasz jednak dodaje: „Ponieważ niektórzy filozofowie nadużywają prawdy do zwalczania wiary, dlatego Apostoł ostrzega: «Baczcie, aby was kto nie zwiódł przez filozofię oraz przez czcze urojenia oparte na podaniach ludzkich [...] a nie na Chrystusie». Zaś Dionizy wyraża się o niektórych filozofach, że «w sposób nieświęty używają tego, co boskie, chcąc drogą nauki boskiej zniszczyć cześć należną Bogu»"22.

Nauka, szczególnie filozofia, jest rzeczą świętą i boską, ale staje się grzechem, gdy przestaje służyć miłości i adoracji Boga, opowiadając się po stronie tych, którzy Go odrzucają i tym sposobem prowadzą do zepsucia ludzi. Można więc w studium popełnić grzech przeciwny dobremu aktowi pilności - grzech zbytniej ciekawośc i. Według Tomasza jest on częstszy niż na ogół się uważa. Można popełnić go w wyżej wspomnianych formach, gdy zachodzi sytuacja zdrady prawego porządku i prawdziwego celu wiedzy. Można popełnić go także w poznaniu rzeczy zmysłowych, a więc w używaniu zmysłów, gdy studium tych rzeczywistości nie jest nastawione na nic użytecznego, ale raczej oddala od rozważania rzeczy wyższych bardziej korzystnego dla człowieka. Następuje wtedy degradacja życia wewnętrznego, sprowadzenie go do banałów w dziedzinie kultury i życia. Studium może być wprost ukierunkowane na coś złego, na przykład na podziwianie piękna rzeczy lub osoby, nawet dzieła sztuki, jeśli prowadzi do grzechu, czy też na obserwowanie drugiego człowieka, by potem o nim plotkować. W takich przypadkach mamy do czynienia z grzechami zbytniej ciekawości. Jeśli natomiast badanie rzeczy zmysłowych ma na celu - co jest naturalne - dostarczenie człowiekowi środków koniecznych do życia (technika, ekonomia, nauki przyrodnicze) lub osiągnięcie

21 Augustyn, De doctrina christiana = O nauce chrześcijańskiej (2, 40, 60), przełożył, wstępem i komentarzem opatrzył J. Sulowski, Warszawa 1989, s. 113. 
większego bogactwa duchowego w poznaniu prawdy, to praktykuje się pilność także w poznaniu rzeczy materialnych ${ }^{23}$.

Piękno ziemskie, widowiska, zabawy, które służą zmysłom, zainteresowanie sprawami innych, mogą być ubogaceniem albo zubożeniem duszy zależnie od tego, co zdominuje pragnienie widzenia, czucia, wiedzy ${ }^{24}$. Dlatego trzeba, aby ta dziedzina - podobnie jak dziedzina wiedzy naukowej i myśli praktycznej - została poddana cnocie.

Tomasz umiał zwrócić swojego ducha do poszukiwania najwyższych rzeczywistości racjonalnych, ukierunkowując tym samym poznanie rzeczy ziemskich i ludzkich na dobro. Wiadomo, jaki jest sens syntezy myślowej, którą zbudował jako mądry architekt. Uniwersalna prawda Boża jest w nim kontemplowana w sobie i w swoich śladach (vestigia) w świecie jako światło stworzenia. Praca intelektualna Tomasza była wielka i różnorodna, ale poddany dyscyplinie duchowej duszy bogatej i czystej nigdy nie zboczył z raz obranego właściwego kierunku i nie pomniejszył prawej intencji, która prowadziła w każdym aspekcie jego studium do Boga. Do badań nie skłaniały go ambicja ani próżność, ani nawet wola samoafirmacji, ale kult pierwszej i wiecznej Prawdy, chęć śpiewania ku jej chwale. Tym, co miało dla niego znaczenie, było służenie Prawdzie, a wszystko inne schodziło na dalszy plan, także rzeczy drogie i godne pochwały wartości. Poświęcając się studiowaniu, nawet wtedy gdy czuł nieuniknione pragnienie spokoju lub działania, trwał w swoim powołaniu. Owszem, działał, ponieważ często „konieczność miłości”, jak zwykł mawiać, wołała głosem silniejszym i wymagała rezygnacji z kontemplacji, ale nie oznaczało to rezygnacji z przyjętego i realizowanego powołania, zubażania dziedzictwa duchowego nagromadzonego za pośrednictwem studium i życia myśli.

Obdarzony wyjątkowym geniuszem i godną podziwu pamięcią, gotowością i szybkością osądu - jak mówi Wilhelm - pewnością spojrzenia, łatwością wyrażania się, starał się używać wszystkich

23 Por. STh II-II q. 167 a. 2.

24 Tamże, ad 2 i 3. 
danych mu zdolności do wytrwałego studium. Od dziecka, od pobytu na Monte Cassino, pokazał swój charakter nastawiony na myślenie, spokój i milczenie. Nie ulegał gwałtowności w mówieniu; był pobożny w modlitwie. Często widziano go z kartką w ręce, na której miał zanotowane wiadomości podawane w czasie lekcji. Jako student w Neapolu szybko pokazał swój przenikliwy geniusz i jego ciągłe wykorzystywanie, aż do prześcignięcia swoich mistrzów. W Paryżu i Kolonii, w szkole św. Alberta Wielkiego, dojrzało jego myślenie. Prostota i nastawienie medytacyjne pomagało mu w pełnym przyswojeniu sobie i pogłębianiu otrzymywanej nauki. Koledzy nazywali go „niemym wołem”. Sądzili nawet, że jest opóźniony w rozwoju. Prowadzone przez Tomasza notatki znalezione przypadkiem przez kolegę i sukces odniesiony w zleconej mu dyspucie akademickiej pozwoliły Albertowi na profetyczną zapowiedź, że jego „ryk” zostanie wkrótce usłyszany w całym świecie.

Jako profesor uniwersytecki Tomasz wyróżniał się swoją wiedzą i metodą, którą posługiwał się w nauczaniu. Nie powtarzał utrwalonych opinii i nie kompilował tekstów zaczerpniętych od innych. Odznaczał się siłą prawdy przyjętej i przeżywanej. Był sugestywny i pociągający. Pobudzał studentów do miłości wiedzy. Traktował jak stwierdził Wilhelm - nowe punkty doktryny nową metodą i odwołując się do nowych racji. Nie bał się nauczać i pisać nowych opinii, do których doszedł dzięki swojemu przenikliwemu osądowi i natchnieniu Bożemu ${ }^{25}$.

W studium, w nauczaniu i pisanych rozprawach Tomasz odznaczał się konsekwencją, umiarkowaniem, poprawnością, które zapewniały mu precyzję, głębię i równowagę w myśleniu. Nie poddawał się porywom i modom intelektualnym, nie pomniejszał ani nie powiększał sztucznie prawdy, nie deformował jej, ale starał się ją widzieć i pokazywać taką, jaką jest. Patrzył uważnie na rzeczy, a potem o nich mówił. Nie tworzył prawdy, ale ją odkrywał, a potem mówił o wynikach swoich odkryć. Nie zadowalał się opisywaniem rzeczy, ale patrzył w głąb i starał się chwycić sens rzeczy.

$25 \quad$ Vita, s. 81, 113. 
Jego ojczyzną intelektualną i duchową było to, co uniwersalne. Tym, co miało dla niego pierwszorzędne znaczenie, była idea, a nie fakty; oczywiście, faktów nie pomijał, ale starał się je odczytywać w świetle wyższej zasady. Poza wszelkim agnostycyzmem, który zamyka się w świecie empirycznym zjawisk bez możliwości przejścia do sfery transcendencji, jak również poza wszelkim abstrakcjonizmem, który traci kontakt z rzeczywistością. Tomasz odkrył analogiczną wartość stworzenia, które nosi w sobie podobieństwo Boże, czyli idealną wartość wieczną. Przez ciemność materii dochodził wytrwale do tej wartości istniejącej w głębi, znajdując w niej for mę jako uczestniczenie w prawdzie i pięknie Boga. Znajdując w Bogu by ci e jako solidną konsystencję stwórczą, a więc substancję rzeczywistości w świecie, pozostając daleko od wszelkiego a kos mizmu deprecjonującego świat. Będąc dogłębnie realistą, Tomasz wychodził od tego, co oczywiste, i poruszał się zawsze po linii tego, co realne, nie tracąc czasu na fantastyczne konstrukcje lub pozbawione realizmu systemy, które mieszają logikę z metafizyką, a to, co się myśli, z tym, co jest. Gdy potem rozum dochodził do spotkania się z wiarą, zmysł analogii konsekwentnie prowadził dalej jego dyskretnego i jasnego ducha, który w niczym nie porzucał rozumu ani w niczym nie pomniejszał wiary. Rozróżniając dobrze między dwoma porządkami, pokazywał ich harmonię opierającą się na pochodzeniu z tego samego źródła - wiecznej myśli Boga, Słowa, które obydwa porządki opromienia światłem intelektualnym, jak dwie różniące się od siebie formy, ale zbiegające się w objawianiu Bożym. Tomasz tworzył w ten sposób fundamentalną zasadę humanizmu chrześcijańskiego - prawdziwe rozwiązanie wiecznego problemu człowieka. Tomasz zasłużył w ten sposób na tytuł Doctor humanitatis, jaki został mu nadany przez papieża Jana Pawła $\mathrm{II}^{26}$.

Wszystko to było możliwe dzięki dyscyplinie wewnętrznej jego poszukiwania i jego wiedzy, kierowanych rozumem i impulsem łaski. Umiał przekroczyć przyciąganie tego, co przygodne i widzialne.

26 Por. Giovanni Paolo II, S. Tommaso „Doctor Humanitatis” guida perenne degli studi con I voti del IX Congresso Tomistico Internazionale (24-29 sett. 1990), Città del Vaticano 1990. 
Umiał wytrwale kontynuować studium, jak i swoje poszukiwanie prawdziwej pokuty. Umiał być pokorny wobec prawdy, czując lęk wobec powołania nauczycielskiego ${ }^{27}$, a jednak kochając je miłością oblubieńczą; stawiał najwyższą Prawdę ponad cząstkowymi prawdami „synów ludzkich”, które nie zdołały przyciągnąć go do siebie. Jego studium i jego myślenie były więc ważnym aspektem jego świętości. Była to świętość rozumu, który przenikał jego myśl i ukierunkowywał każdą poznaną prawdę stworzoną na żywą i transcendentną prawdę Bożą. Dla Tomasza studium było elementem wstępowania duchowego - było modlitwą.

3. Ostatnim etapem wędrówki wewnętrznej była dla Tomasza kontemplacja. Jest rzeczą konieczną, aby życie duchowe znalazło swoją jedność w „centrum” zbiegania się i promieniowania, które tworzy wokół siebie porządek i harmonię. Tym centrum może być tylko Bóg, najwyższa przyczyna każdej rzeczy, w świetle której można osądzać „z wysoka” ja i świat, historię i wydarzenia. Trzeba wznieść się bardzo wysoko, by móc widzieć we właściwym świetle, w jej wartości i w jej proporcjach każdą rzecz, małą i wielką - trzeba wznieść się na szczyty świata ducha, by zrozumieć świat, który otacza człowieka w jego codzienności.

Wtedy w tym, co stworzone, widzi się fascynującą zbieżność linii biegnących z różnych stron, jako wyrażenie ich pozytywności ontologicznych, by wszystkie spotkały się w Bogu. Wtedy całe życie dostosowuje się do tej wizji wewnętrznej jako porządek etyczny podtrzymywany przez szkielet metafizyczny. Duchowość sprawia przede wszystkim, że wszystkie wyrażenia bytu spotykają się w ruchu wstępującym, który zwieńcza spokojna kontemplacja Boga. Życie intelektualne zostaje wtedy przeniknięte przez miłość. Rodzi się z miłości jak z pierwszego impulsu, który skłania do poszukiwania i kontemplacji Boga; jest ciągle pobudzana przez miłość, która zapala rozum, nie pozwalając mu nigdy na zamknięcie się w tym, co osiągnięte; kończy się w miłości, która jest poznaniem stającym się życiem. Mądrość, będąca darem Ducha Świętego (oprócz

27 Por. Vita, s. 85. 
tego, że jest cnotą intelektualną), jednoczy organicznie ludzkie władze duchowe poznania i miłowania, a tym samym je udoskonala. Poznanie miłujące i miłość kontemplująca rodzą się z niej i dzięki niej rozwijają, wznosząc się aż do „dotknięcia” Boga, jakby osiągając jego tajemnicze doświadczenie, które jest non solum discens, sed et patiens divina, jak mówi Tomasz za Dionizym Areopagitą ${ }^{28}$. W tym doświadczeniu i jakby Boskiej pasji życie osiąga swoją jedność. Stąd widać potem całą panoramę wiedzy koncentrującej się na Bogu jako Prawdzie, całe rozwijanie się życia w Bogu jako Miłości, cały wszechświat zależący od podtrzymywania przez rozum i miłość za pośrednictwem Boga, będącego czystym Byciem, czystym Aktem, zasadą i celem każdej rzeczy, którego na szczytach ducha kontempluje się jako absolutną Tajemnicę (Ojca, Syna i Ducha Świętego), otoczoną ciemnością jaśniejącego światła, wprawdzie niewyrażalnego pojęciowo, ale dotykalnego duchowo w Jego wiecznym życiu myśli i miłości, w których uczestniczy dusza. Wokół tej zasady kształtuje się porządek wewnętrzny, harmonia tego, co ludzkie, a dusza osiąga szczęście nieporuszonego pokoju, czując się „dzieckiem Bożym"29.

Gdy przylgnięcie do Boga jest pełne, a dusza została napełniona światłem, jakby osiągnąwszy dojrzałość, otwiera się na komunikowanie owoców swojej kontemplacji. Jak odwieczne Słowo w łonie Trójcy Świętej nie tylko pochodzi od Ojca, ale także tchnie Ducha-Miłość, tak kontemplacja wewnętrzna napełnia się miłością zmierzającą do działania. Życie kontemplacyjne rozwija się w życie czynne. Modlitwa wyraża się w dziełach apostolskich. Myśl inspirowana przez miłość staje się życiem, nie zamykając się w sobie ani nie wyczerpując się w sobie, jak ma miejsce w wielu pozachrześcijańskich formach mistyki. Nie ma wtedy sprzeczności między tym, co wewnętrzne, i tym, co zewnętrzne, między taką czy inną formą życia, gdyż wtedy kontemplacja i działanie mają źródło w jedynym oceanie boskości kontemplowanej i kochanej, której służy się

28 Dionizy Areopagita, De divinis nominibus, c. 2; STh I-II q. 22 a. 3 ad 1; II-II q. 45 a. 2.

29 Por. STh II-II q. 45 a. 6. 
na wszystkich poziomach życia ${ }^{30}$. Nie ma już żadnej antynomii, ale jest tylko wibrująca, witalna synteza myśli i miłości.

Tomasz był in miro modo contemplativus, jak stwierdza jego biograf. Jego świętość była rzeczą rozumu, ale rozumu nieustannie poruszanego i podnoszonego przez miłość. Jak mądry architekt znalazł on punkt oparcia swojej syntezy naukowej i swojego życia. On, który od dziecka w opactwie na Monte Cassino uparcie pytał mnichów: „Powiedzcie mi, kim jest Bóg?”, uczynił z Boga kochanego, odkrywanego, posiadanego w głębokim milczeniu czystej duszy, centrum swojego życia i swojej myśli. Wiadomo, że jego Summa theologiae jest, jak zostało trafnie zauważone, jakby „biografią Boga” biografią kontemplowaną i przemodloną, która stała się osobistym życiem Tomasza. On za nią prawie zupełnie znika, aby zostawić całe miejsce przedmiotowi swojego wykładu. Wyszedłszy z siebie w ekstazie miłości, Tomasz robi miejsce Bogu, prawdziwemu Panu jego myśli. Jeśli pojawią się w Sumie czy też w innych dziełach jakieś ślady osobistego zaangażowania Tomasza - a takie również można znaleźć - to służą one tylko lepszemu wydobyciu tego, kim jest Bóg.

W życiu Tomasza na pewno były porywy, poruszenia, płacz, modlitwa prywatna i chórowa, posty, pokuta, wielka troska o Kościół i nieustanne pragnienie Boga. Miał swoje osobiste życie duchowe i posiadał nadzwyczajne dary. Niektóre z jego pism zostały napisane w ekstazie. Doświadczał także objawień. Często na modlitwie znajdował rozwiązania najtrudniejszych kwestii; mówił, że więcej zrozumiał u stóp Ukrzyżowanego niż dzięki książkom. Niekiedy ukazywali mu się święci, aby wyjaśnić mu trudne zdania z Pisma Świętego. Był prawie stale oderwany od tego, co zmysłowe, zjednoczony z Bogiem w tajemniczych obszarach czystego rozumu, tam gdzie nie ma dostępu żadna próżność tego świata. Był obdarzony duchem profetycznym, ale nigdy nie mówił o swoich doświadczeniach mistycznych ani nie uznawał ich za kryterium tego, czego nauczał. Gdy mówił, nie zwracał uwagi na siebie, ale troszczył się o przekazanie samej Prawdy - Boga.

30 Por. tamże, a. 3; q. 183 a. 4 ad 2; q. 188 a. 6. 
Wszystko, co mówił, wypływało jednak z serca przepełnionego Bogiem. W jego dziełach można znaleźć liczne ślady wskazujące na osiągnięte życie mistyczne. Rozpoznaje się w nich te same kwestie, o których rozmawiał z Ukrzyżowanym i z Maryją. W czasie oficjum, szczególnie w czasie komplety w okresie Wielkiego Postu, czuł, że jego serce uspokaja się, rozważając przemijalność rzeczy i życia ziemskiego. Pobudzając w sobie pragnienie Boga, poruszał się do łez. W czasie mszy płakał i wpadał w ekstazę. Dwa razy otrzymał od Ukrzyżowanego boską aprobatę: „Dobrze napisałeś o mnie, jakiej nagrody oczekujesz?” odpowiedział: „Tylko Ciebie, Panie!”31.

Pełnię kontemplacji, którą się cieszył, Tomasz przekazywał $\mathrm{w}$ swoim nauczaniu (sine invidia communico), w przepowiadaniu, w książkach, w rozmowach, w konsultacjach teologicznych i radach praktycznych ${ }^{32}$. Gdy przepowiadał w swoim słodkim dialekcie neapolitańskim, poruszał tłumy. Zostawiał wtedy na boku subtelne podziały scholastyczne i dzielił się myślą, która stała się życiem. Kierował się programem: contemplata aliis tradere ${ }^{33}$. Dotykał serc wiernych, dając im po prostu Boga. Jak zauważył Wilhelm, w Tomaszu dokonywał się jakby ruch kolisty: zaczynał od zwrócenia swojej myśli w kierunku Boga przez modlitwę, a kończył, zstępując od Boga do bliźniego za pośrednictwem nauczania, a potem od bliźniego znowu wznosił się do Boga, modląc się i kontemplując, by na nowo jeszcze raz zacząć taki witalny cyk ${ }^{34}$.

Gdy było konieczne, stawał się także polemistą, skoro mędrzec wie, że musi bronić prawdy i zwalczać błąd ${ }^{35}$. Jeśli nie on, to kto miałby to robić? W swoim życiu apostolskim Tomasz musiał podjąć wyjątkowo wiele walk z błędami, niejednokrotnie bardzo poważnymi. Jak napisał Chesterton, Tomasz przeszedł przez życie pośród wybuchających bomb. Jego dzieło nie ogranicza się jednak do tej funkcji negatywnej, choć i ona była owocem jego medytacji. Za

\footnotetext{
31 Por. Vita, s. 87, 103, 114, 116, 118, 130.

32 Por. tamże, s. 96, 108, 121.

33 STh II-II q. 188 a. 6.

34 Por. Vita, s. 122.

35 Por. Tomasz z Akwinu, Summa contra gentiles, 1, 1.
} 
każdym razem chodziło mu o wydobycie prawdy i ukazanie jej witalnego znaczenia dla człowieka.

Dary Ducha Świętego były wewnętrznym źródłem jego słowa. Jego odczuwanie tajemnicy czyniło go dyskretnym, dzięki czemu także w mówieniu o Bogu nie wykraczał poza pewne granice. Wewnętrzne oświecenie nadprzyrodzone uskrzydlało jednak jego rozumowanie, stające się pieśnią uwielbienia. Wtedy cała dusza Tomasza była poruszana słodkim i gorącym porywem. Jako teolog i poeta połączył w sobie przejrzystość nieba i głębię oceanu ${ }^{36}$. Poryw mistyczny był żywym wyrazem jego myśli. Był to rozum, który się modli; była to kontemplacja, która sięgała szczytowych możliwości człowieka i odsłaniała wszystkie swoje bogactwa i harmonie, wszystkie swoje blaski i całą swoją słodycz. Żywe słowa zrodzone z tej kontemplacji i zapisane w hymnach Tomasza wciąż tchną pobożnością i wzniosłością mistyki, z której się narodziły i której pozostają zwierciadłem. Są one ciągle szkołą doświadczenia duchowego dla kolejnych pokoleń, które spotykają się w nich z bijącym sercem Tomasza.

Przed śmiercią Tomasz podjął się ostatniego komentarza i wygłosił ostatnią lekcję, której przedmiotem był poemat o miłości: Pieśń nad pieśniami. Jego życie intelektualne w ten sposób symbolicznie zamykało się pod znakiem miłości, aby otworzyć się na widzenie. To było rzeczywiście życie, „życie żywe”, chciałoby się powiedzieć, a nie gra abstrakcji czy też, co gorsza, iluzji, nie zimna i bezduszna służba zamknięta na to, co ludzkie. Tomasz konsekwentnie zachował i potwierdzał swoje człowieczeństwo w sposób integralny i intensywny; podniósł je do Boga za pośrednictwem myśli i miłości. Jego myśl nie była bez miłości, a miłość nie była bez myśli, jak w Bogu, w którym Słowo nie jest bez Ducha, a Duch pochodzi od Słowa. I jak w Bogu, tak myśl-miłość w życiu Tomasza były działaniem, wielkim rozprzestrzenianiem dobra i światła.

Doszedłszy do szczytu, w pełni swojej dojrzałości ludzkiej i duchowej przechodził do wieczności. Przechodził do oglądania

36 Por. R. Wielockx, „Adoro te devote”. Zur Lösung einer alten Crux, „Annales Theologici" 21 (2007), s. 101-140. 
Boga-Prawdy, którego czcił usilną pracą rozumu, i Boga-Miłości, którego ukochał na co dzień. Przeszedłszy przez cienie, teraz może widzieć „twarzą w twarz”. Posiadł już w pełni to światło, które pewnego dnia porwało jego ducha, tak że nieodwołalnie odłożył pióro. Wobec prawdziwego oblicza Prawdy powiedział, że to wszystko, co napisał, jest tylko „słomą". Intelektualista na takim poziomie nie mógł umrzeć inaczej, jak tylko w klimacie pokory i milczenia.

\section{POSŁUGA SŁOWA}

Jezus Chrystus powierzył Kościołowi „posługę przepowiadania” $(\mathrm{Dz} 6,4)$, która polega na rozpowszechnianiu Jego prawdy w świecie i uświęcaniu nią świata ${ }^{37}$. W gruncie rzeczy jest to ciągłe przedłużanie w świecie posłania Jezusa Chrystusa (por. J 17, 18; 20, 21), służba prawdzie i dawane jej świadectwo (por. J 18, 37). Jest to wzniosły urząd i poważna odpowiedzialność, wokół których urzeczywistnia się cała posługa duszpasterska kapłanów i cały apostolat Kościoła - zarówno pasterzy, jak i świeckich - w świecie, jak mocno podkreślił II Sobór Watykański. Wszyscy powołani mogą także w tej działalności otrzymać światło z przykładu i nauki Akwinaty przekazującego prawdę, która stała się ciałem w Jezusie Chrystusie, na którego po wcieleniu możemy patrzeć jako na nasz przykład, aby „widzieć odbicie najczystszego i pełnego majestatu oblicza Boga"38 i aby odtwarzać w naszym ludzkim słowie - będącym narzędziem prawdy - słowo Boże.

1. Słowo ludzkie służące przepowiadaniu, podobnie jak słowo Boże, powinno być słowem pokornym. Pokora Chrystusa nie jest paradoksem, ale jest faktem. On jest Tym, który „będąc w postaci Bożej, nie uważał za grabież równości swej z Bogiem, ale wyniszczył sam siebie, przyjąwszy postać sługi, stawszy się podobnym do ludzi i postawą znaleziony jako człowiek. Sam się uniżył, stawszy się posłusznym aż do śmierci, a śmierci krzyżowej" (Flp 2, 6-8). On jest Tym, który „nauczył się posłuszeństwa z tego,

37 Por. G. Cottier, Uświęceni w prawdzie, tłum. M. Romanek, Poznań 1996.

38 Por. Klemens Rzymski, List do Kościoła w Koryncie, 36, 2. 
co wycierpiał" (Hbr 5, 8), który nie wstydził się być uznanym za ubogiego rzemieślnika, „syna cieśli”, „syna Józefa” (Mt 13, 55; Łk 4, 22). Można by powiedzieć dzisiejszym językiem, że Jezus jako człowiek w pełni uznawał swoje ograniczenia, co widać w Jego posłuszeństwie Ojcu, w odmowie objawienia dnia końca świata (por. Mk 13, 32) i w podejmowanym działaniu (por. J 5, 19). Uznaje i głosi boskie pochodzenie swojej myśli i swojej postawy "pokory” w pełnionej misji, która została Mu powierzona: „Moja nauka nie jest moja, ale tego, który mię posłał. Jeśli kto chce pełnić wolę Jego, dowie się o tej nauce, czy jest z Boga, czy też Ja sam za siebie mówię" (J 7, 16-18; por. 8, 50). Chodzi o pokorę „intelektualną”, która będąc odrzuceniem ambicji i wyniosłości, profanujących orędzie prawdy, jest także gwarancją samej prawdy, nienaruszonej przez snobizm, zadufanie w sobie, agresywność. Jezus, pokorny i posłuszny względem Ojca, jest także „cichy i pokornego serca” z ludźmi (Mt 2, 29).

To jest duch i wzór, który powinien wyróżniać każdego sługę prawdy. Sam Kościół został ustanowiony przez Chrystusa, aby kontynuować ewangelizację ubogich, to znaczy pokornych i cichych, którą On zapoczątkował. Kto jest wyniosły i pewny siebie, łatwo zdradza prawdę, podporządkowuje ją swojemu punktowi widzenia, chełpi się swoją myślą, dochodząc dobrowolnie do zaślepienia. Jest to dramat ludzki, do którego nawiązanie znajdujemy w Liście do Rzymian, gdy św. Paweł mówi o tych, którzy „poznawszy Boga, nie oddali Mu chwały jako Bogu ani nie dziękowali, ale znikczemnieli w myślach swoich i zaćmione jest ich bezrozumne serce" (1, 21-22). Ileż wyrosło herezji, ileż stoczono nieużytecznych walk, ileż prowadzono bezpłodnych polemik, ileż stracono czasu, z powodu braku pokory w poszukiwaniu i nauczaniu prawdy!

Miłość - odznaczająca się przymiotami, o których św. Paweł mówi w hymnie o miłości w Pierwszym Liście do Koryntian - do prawdy jest koniecznością, nawet poza własnym systemem i własnym piedestałem. Trzeba ją bardziej uznawać niż tych wszystkich, którzy aprobują wyniki naszych poszukiwań. Trzeba ciągle być świadomym, że prawdę posiadamy tylko w sposób częściowy i że nasz bliźni w pewnych punktach widzi prawdę wyraźniej i lepiej ją przekazuje. Trzeba stale kontrolować się, czy nie prezentuje się postawy 
nietykalnego i nieomylnego dogmatysty, gotowego uderzyć każdego, kto prezentuje inny pogląd czy punkt widzenia. Takie zjawisko widzimy bardzo wyraźnie na przykład wtedy, gdy zadeklarowani zwolennicy demokracji, mający ją nieustannie na ustach, nie znoszą ludzi prezentujących inne zdanie, nawet w banalnych kwestiach. Chodzi w gruncie rzeczy o bardzo prostą sprawę, a mianowicie o nauczenie się mądrości bez udawania i bez hipokryzji oraz o przekazywanie jej bez zarozumiałości i bez zazdrości (por. Mdr 7, 13). Tomasz i pod tym względem pozostaje wzniosłym wzorem.

Jest to postawa, którą trzeba przejąć się w życiu, jeśli chce się wzrastać w prawdzie i do prawdy skutecznie prowadzić innych. Zwłaszcza jako wykładowcy i kaznodzieje musimy zaczerpnąć mocy z zapomnianych dzisiaj cnót prostoty, pokory, łagodności, kontemplacji, modlitwy ${ }^{39}$.

Potrzeba pobożności, która wykracza poza czystą wiedzę, poza sferę myślenia, poza nasze ja. Nagroda jest nieskończenie wielka i to jest nasza nadzieja. Nagrodą, której można się spodziewać, gdy jest się pokornym i uczciwym sługą światła, jest radość $\mathrm{w}$ prawdzie i z prawdy (gaudium de veritate), jest płodność mądrości. Starotestamentowy mędrzec tak pochwala mądrość: „Nieprzebranym bowiem jest skarbem dla ludzi, a ci, którzy go używali, stali się uczestnikami boskiej przyjaźni, dla darów umiejętności zaleceni” (Mdr 7, 14). Arystoteles pisał: „Rozum jest czymś boskim w stosunku do człowieka", a życie zgodne z nim podnosi człowieka do boskości ${ }^{40}$.

Kto w Kościele i świecie ma zadanie nauczania i przepowiadania, musi dużo zastanawiać się nad swoją bardzo paradoksalną sytuacją, którą przypomina napomnienie ewangeliczne, aby nie chcieć być nazywanym „nauczycielem”, mimo że za takiego jest uważany i tak jest nazywany. Jezus mówi jednoznacznie: „Ale wy nie dajcie się nazywać: rabbi; albowiem jeden jest nauczyciel wasz. [...] Ani się nie nazywajcie nauczycielami, gdyż jeden jest nauczyciel wasz,

39 Por. H. U. von Balthasar, Wenn ihr nicht werdet wie dieses Kind, Ostfildern 1989.

$40 \quad$ Arystoteles, Etyka nikomachejska 10, 7 (1177b). 
Chrystus. Kto z was jest większy, niech będzie sługą waszym; kto by się zaś wywyższał, będzie uniżony; a kto by się uniżał, będzie wywyższony” (Mt 23, 8.10-12). Tomasz tak komentuje te słowa: „Co Jezus chce powiedzieć? Należy zauważyć, że właściwie nauczycielem jest ten, kto ma swoją naukę, a nie ten, kto przekazuje innym naukę przekazaną mu przez kogoś drugiego. Dlatego jest tylko jeden nauczyciel, to znaczy Bóg, który właściwie biorąc, ma swoją naukę. On ją ma jako twórca; podrzędnie są jednak liczni nauczyciele. Jeśli ty usiłujesz być autorytetem, szukasz tego, co należy do Boga, ale jeśli chcesz być sługą [nauki], szukasz tego, co jest właściwe pokorze. Dlatego [Jezus dodaje] największy wśród was będzie waszym sługą, czyli nie będzie chciał być niczym więcej niż sługą. Chrystus przypisuje sobie nauczanie, ponieważ On jest Słowem, i dlatego Jemu przysługuje nauczanie, ponieważ nikt nie naucza bez pośrednictwa słowa. Równocześnie jest nauczycielem według natury ludzkiej, ponieważ został posłany, aby nauczać" ${ }^{\prime 1}$.

Jakakolwiek jest dziedzina, której się naucza, nauczanie jest zawsze byciem rzecznikiem wiecznego Słowa, i bardzo trzeba uważać, aby go nie zafałszować. Trzeba o tym pamiętać przede wszystkim wtedy, gdy naucza się nauki Bożej. Pryncypium tego nauczania stanowi uznanie się za wiernego sługę Słowa, za pokornego siewcę prawdy, którą powierzył sam Bóg. Kaznodzieja, apostoł czy teolog, którzy kochałby bardziej siebie i swoją naukę niż Boga, który bardziej ceniłby swoje rozumowanie niż stwierdzenia Ewangelii, zdradza swoją misję, zapominając, że trzeba znać jedną tylko rzecz (unum necessarium), że trzeba szczycić się jedną mądrością i jedną tylko przekazywać: Jezusa, i to Jezusa Ukrzyżowanego (por. 1 Kor 1, 23; 2, 2). Warto pamiętać o tym, iż Tomasz za właściwą katedrę nauczycielską Chrystusa uznaje Jego krzyż - cathedra magistri docentis ${ }^{42}$. Tylko czerpiąc naukę z tej katedry, można się ustrzec tego, co ojcowie kapadoccy zdecydowanie demaskowali jako „bałwochwalstwo pojęć”.

$41 \quad$ Tomasz z Akwinu, Super Matthaeum, c. 23, 1; por. także STh I q. 117 a. 1 ad 1; De veritate, q. 11 a. 1.

42 STh III q. 46 a. 4. 
2. Słowo, które się przepowiada i którego się naucza, musi być następnie słowem świetlistym, to znaczy bogatym w światło i oświecającym. Funkcją słowa jest przekazywanie światła, wyrażanie pojęcia, w zrodzeniu którego myśl niejako przebija ciemność rzeczy, wydobywając z nich duszę prawdy, czyli formę. Słowo tego, kto został powołany przez Boga, kto w jakiś sposób otrzymał ze strony Kościoła mandat przekazywania prawdy ewangelicznej, powinno być szczególnym świadectwem dawanym Wiecznemu Światłu, wyraźną kontynuacją posłania Jezusa, który przyszedł, aby zaświadczyć o prawdzie (por. J 18, 37), poszerzaniem horyzontu ducha ludzkiego, aby zrozumieć całą wysokość i głębię Boga (por. Ef 3, 18); powinno być oświeceniem tego, kto przebywa w mroku (por. Łk 1, 79), rozdawaniem bogactw Chrystusa (por. Ef 3, 8), objawieniem ukrytej tajemnicy Boga (por. Ef 3, 9; Kol 1, 26).

Można powiedzieć, że w pewnych przypadkach słowo powinno nabierać także kształtu polemicznego, gdyż taki przymiot miało słowo Chrystusa, gdy wypowiadał się przeciw hipokryzji i przeciw niesprawiedliwości, czyli przeciwko dwóm przeszkodom uniemożliwiającym Bogu wejście do serca ludzkiego i do społeczeństwa. Widzimy, że przeciw tym dwóm grzechom trzeba dzisiaj koniecznie i z mocą walczyć, aby robić miejsce dla Boga. Słowo musi jednak być przede wszystkim świadectwem i objawieniem, musi być pogodne, jasne, wprowadzające pokój, jak czyni mądrość. Należy domagać się, by zdjęto maski z obliczy nowych faryzeuszy, którzy kryją się za sloganami wolności, demokracji, braterstwa, sprawiedliwości społecznej, nowego humanizmu, tolerancji itd. Trzeba jednak pamiętać, że samo demaskowanie błędu nie jest jeszcze budowaniem - budowanie może dokonywać się tylko w prawdzie. Prawda Boża przenika aż do głębi ducha; oświeca i rozbija najciemniejszą noc; daje prawdziwą wolność (por. J 8, 32). Trzeba wierzyć w prawdę i w Tego, który powiedział: „Ja jestem Prawdą!” (J 14, 6).

Aby słowo chrześcijańskie było świetliste i aby rozpraszało ciemności, tak jak słowo Jezusa musi rodzić się w głębi: „Boga nikt nigdy nie widział; jednorodzony Syn, który jest na łonie Ojca, On opowiedział” (J 1, 18). Trzeba długo przebywać na łonie Ojca, trzeba zanurzyć się w odpoczynku kontemplacji, aby móc mówić do innych 
o Jego cudowności i Jego wspaniałych dziełach. Trzeba tam często powracać, aby nie opróżniły się nasze cysterny. Ideałem mądrego chrześcijanina jest oświecająca kontemplacja, o której mówił Akwinata jako dziedzic klasyczności chrześcijańskiej, gdy formułował ideał życia "złożonego", to znaczy takiego, w którym kontemplacja rozwija się w działaniu, a działanie staje się służbą kontemplacji: Contemplari et contemplata aliis tradere ${ }^{43}$. Aby pełnić posługę oświecania, trzeba mieć światło, stale pozostając w kontakcie ze źródłem światła.

3. Jeśli chodzi o prawdę Bożą, to słowo, które ją przedstawia, musi być także pobożne. Jest oczywiste, że nie można mówić o Bogu i o tym, co Go dotyczy (teologia), jak mówi się o wzorze matematycznym czy o tekście literackim. Jeśli nie ma zagadnienia lub materii, które nie mogłyby wzbudzić pasji poszukiwania i pozwolić zagustować w dokonywanym odkryciu, to z jeszcze większą słusznością trzeba powiedzieć, że u początku apostolatu jest nauka Boża, która pochodzi z miłości i zmierza do wzbudzenia miłości, nauka, która musi zainteresować i przeniknąć całego człowieka, pozwalając mu zasmakować w rzeczywistości Bożej i wzbudzając w nim gorliwość o sprawę Bożą. To jest „sympatia z tym, co boskie”, jak za Dionizym mówił Tomasz ${ }^{44}$.

Chodzi o miłującą kontemplację, która zakłada, a zarazem rozwija zażyłość ducha z Bogiem na gruncie miłości nadprzyrodzonej, w której zanurza swoje korzenie wlany dar mądrości. Dusza wsparta w ten sposób przez działanie Ducha Świętego i zamieszkana przez Niego pod Jego wpływem, jakby za pośrednictwem niewymownej miłości, dochodzi do „kosztowania” Boga ${ }^{45}$. Jest to głębokie spojrzenie, które wnika w tajemnicę Boga, tam, gdzie tylko duch Boży może widzieć i wiedzieć. Jest to uczestniczenie człowieka w poznaniu integralnym i w doskonałej mądrości, przez którą Bóg poznaje swoje niezgłębione głębie (por. 1 Kor 2, 11). Wtedy człowiek kłania się całym sobą przed majestatem Przenajświętszej

\footnotetext{
43 STh II-II q. 179 a. 2 ad 2; q. 182 a. 2 ad 2; a. 4 ad 2; q. 188 a. 2 ad 1.

44 Dionizy Areopagita, De divinis nominibus, c. 4; STh II-II q. 45 a. 2.

45 Por. STh I q. 43 a. 5 ad 2.
} 
Trójcy. Jego dusza staje się orantką i adoratorką; cały jego byt zostaje przeniknięty i ożywiony spotkaniem z Bogiem. Z ducha szczerze i z czystością poświęconego pokornemu poszukiwaniu i miłującej kontemplacji rzeczywistości niebieskich wypływa słowo pełne świadomości i pobożności. Jest to słowo promieniujące przekonaniem i mądrością, które było modlitwą, zanim stało się kazaniem lub lekcją, i które zarówno jako modlitwa, jak również jako przepowiadanie jest zawsze śpiewem chwały Bożej. Ma zawsze charakterystyczną pieczęć - jakby echo, które zdaje się dobiegać z odległych obszarów. Kto go słucha, odkrywa niewątpliwie jego pochodzenie oraz otrzymuje z niego łaskę i radość. Coś takiego można rozpoznać w Magnificat Maryi.

Kto wypowiada słowo Boże, nie ogranicza się do oświecenia dokonywanego za pośrednictwem rozumu, ale musi zaangażować także swoje serce w działanie zmierzające do Boga: nie tylko do „Boga filozofów", do czystego Aktu i pierwszego Poruszyciela, ale do Boga żywego - „Boga Abrahama, Izaaka i Jakuba”, do „Słowa, które tchnie miłość" i które jako miłość daje się duszom, czyniąc je uczestnikami niewymownego smaku daru trynitarnego ${ }^{46}$. Nauczyciel chrześcijański powinien więc stale pamiętać, że miłość Jezusa przekracza wszelkie poznanie (por. Ef 3, 14) i że tylko dusza słodko zraniona przez miłość Ukrzyżowanego może wlać w tego, kto słucha, żywe i ożywiające poznanie Boga. Wtedy dopiero będzie mógł wypowiadać słowo podobne do słowa Jezusa, jedynego, doskonałego adoratora Ojca, słowo, które pochodzi z wysoka i które wnika w głąb, aby objawiać chwałę Bożą.

4. Nie ulega wątpliwości, że wypowiadane słowo, aby było skuteczne, musi być w końcu słowem ukrzyżow an y m, jak Jezus jest Słowem ukrzyżowanym. Został On ukrzyżowany dwa tysiące lat temu, ponieważ nie chciano Go słuchać, ponieważ obawiano się światła, które przyniósł. Jest ukrzyżowany stale w swoim Kościele. Odzwierciedla się w tym fakcie wieczny konflikt. Słowo przyszło, zajaśniało Światło, ale ciemności nie chcą Go przyjąć,

46 Por. tamże, a. 3 i 5. 
duch ludzki, który jest Jego odbiciem, buntuje się przeciw Niemu (por. J 1, 15). Stąd nieustanna walka ze Światłem - stąd krzyżowanie Słowa. Ktokolwiek zdradza prawdę, krzyżuje Słowo. Ktokolwiek jest nośnikiem kłamstwa - w czterech ścianach domu czy w środkach masowego przekazu - jest ciemnością walczącą ze światłem. Święty Paweł pisał z więzienia: „Słowo Boże nie jest związane” (2 Tm 2, 9).

Jest prawem, które kieruje głoszeniem słowa w ekonomii zbawienia, że tylko jeśli słowo jest ukrzyżowane, nabiera pełnej skuteczności odkupieńczej. Dlatego krew męczeńska jest najwymowniejszym świadectwem chrześcijańskim i objawia jego najpełniejszą moc.

Trzeba, aby także nauczyciel chrześcijański, jeśli chce uczestniczyć w dziele odkupienia i odnowienia człowieka, wniósł w niego wkład cierpienia i ekspiacji, czyniąc to z takim samym poświęceniem, z jakim Jezus przyjął krzyż. Może to być wysiłek osiągnięcia szczerości i jasności, zdecydowane dążenie wewnętrzne do osiągnięcia pewności; może to być zmierzenie się z pokusą agnostycyzmu i racjonalizmu; może to być trwanie w niełatwym przekonaniu, że „prawda jest mocna sama w sobie i nie może zostać pokonana przez żadne zastrzeżenie" ${ }^{47}$; może to być trud i zmęczenie z powodu studiowania; może to być cierpliwość wobec niezrozumienia i niepowodzenia; może to być pokora, która uznaje swoje ograniczenia i swoją niewystarczalność, przede wszystkim wobec ostatecznej Tajemnicy - pokora przeradzająca się w adorację; może to być rezygnacja z rozmaitych radości, łatwych sukcesów i próżnej chwały, którą oferuje świat; może to być „wstrzemięźliwość w nauce” i cała asceza życia intelektualnego, opisana przez Tomasza w dwóch interesujących artykułach poświęconych „ascetyce myśli” ${ }^{48}$. W każdym jednak razie zawsze chodzi o realne ukrzyżowanie.

Opisane wyżej przymioty słowa są darami, o które trzeba prosić Boga - są także „mocami”, które czynią nauczyciela chrześcijańskiego godnym słowa i uzdalniają go do podjęcia poważnej odpowiedzialności za jego rozpowszechnianie w świecie. Pokora czyni wiernymi prawdzie; światło wewnętrzne rozlewa się na dusze; pobożność

47 Tomasz z Akwinu, Summa contra gentiles, 4, 10.

48 Por. STh II-II q. 147 a. 1 i 2. 
pozwala odczuć w słowie jego boski smak; cierpienie czyni skutecznym i dotykalnym składane świadectwo. Są to cztery przymioty Tomasza jako nauczyciela chrześcijańskiego i kapłańskiego, które rzucają aktualizujące światło na dzisiejsze problemy dotyczące nauczania i studium, które mogą inspirować każdego wykładowcę i każdego studenta. Tomasz ciągle może być aktualny w dzisiejszym Kościele ${ }^{49}$.

Kryzys, który dogłębnie znaczy współczesną cywilizację i kulturę, mając głębokie korzenie duchowe, nie został jeszcze zażegnany i światli ludzie szukają możliwych i odpowiednich rozwiązań. Każdy chrześcijanin jest powołany do wniesienia osobistego wkładu w to dzieło, mające podstawowe znaczenie dla całej ludzkości. Trzeba jednak, by ten wkład został natchniony przez wieczną prawdę Boga i oświecony światłem intelektualnym Słowa. Nie ma rozwiązań, które pojawią się niespodziewanie i same czy nawet wbrew nam nas ocalą. Nie ma siły tylko ludzkiej, która mogłaby zapewnić stworzenie nowego świata. Świat potrzebuje słowa i łaski Jezusa Chrystusa. Kto będzie sługą wiernym temu słowu i tej łasce, da światu światło i ziemi sól mocą Ducha Świętego, który jako jedyny stwarza i odnawia wszystkie rzeczy.

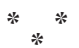

Na zakończenie przeprowadzonych poszukiwań proponuję sięgnąć do inspirującej modlitwy umieszczonej przy grobie św. Tomasza z Akwinu w Tuluzie, która pod wieloma względami streszcza zarówno jego duchowość, jak i to, co zostało tu wydobyte z jego doświadczenia duchowego i z jego pism:

Panie, Ty wiesz lepiej niżeli ja sam, że się starzeję i pewnego dnia będę stary. Zachowaj mnie od zgubnego nawyku mniemania, że muszę coś powiedzieć na każdy temat i przy każdej okazji. Odbierz mi chęć

49 Por. H. U. von Balthasar, Thomas von Aquin im kirchlichen Denken von heute, "Gloria Dei" (Seckau), 8 (1953), s. 65-76; A. Hayen, San Tommaso e la vita della Chiesa oggi, Milano 1993. 
prostowania każdemu ścieżek. Uczyń mnie poważnym, ale nie ponurym, czynnym, lecz nie narzucającym się. Szkoda mi nie spożytkować wielkich zasobów mądrości, jakie także posiadam, ale Ty, Panie, wiesz, że chciałbym zachować paru przyjaciół do końca życia. Wyzwól mój umysł od niekończącego się brnięcia w szczegóły i daj mi skrzydła, bym w lot przechodził do rzeczy. Zamknij mi usta w przedmiocie mych niedomagań i cierpień, w miarę jak ich przybywa, a chęć wyliczania ich staje się z upływem lat coraz słodsza. Nie proszę o łaskę rozkoszowania się opowieściami o cudzych cierpieniach, ale daj mi cierpliwość wysłuchiwania ich. Nie śmiem Cię prosić o lepszą pamięć, ale proszę Cię o większą pokorę i mniej niezachwianą pewność, gdy moje wspomnienia wydają się sprzeczne z cudzymi. Użycz mi chwalebnego poczucia, że czasem mogę się mylić. Zachowaj mnie miłym dla ludzi, choć z niektórymi z nich doprawdy trudno wytrzymać. Nie chcę uchodzić za świętego, ale zgryźliwi starcy to jeden ze szczytów osiągnięć szatana. Daj mi zdolność dostrzegania dobrych rzeczy w nieoczekiwanych miejscach, a w ludziach niespodziewanych zalet. Daj mi, Panie, łaskę mówienia im o tym. 


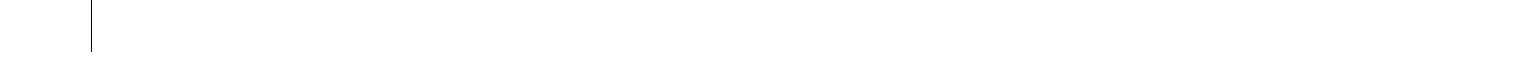




\section{ROZDZIAŁ XII}

\section{来 \\ Sensus fidei i sensus fidelium a zadania teologii}

Dokument Teologia dzisiaj Międzynarodowej Komisji Teologicznej syntetycznie zachęca, by w uprawianiu teologii pośród wielu czynników uwzględniać także sensus fidelium ${ }^{1}$, a nawet zdaje się kłaść pewien nacisk na ten postulat. Jest to postulat dość tradycyj$n^{2}$, ale - trzeba to podkreślić - nie zostało dotychczas jakoś całościowo zaproponowane, w jaki sposób praktycznie realizować go $\mathrm{w}$ teologii.

Postulat uwzględniania sensus fidelium w teologii jest dzisiaj niełatwy do zrealizowania $w$ ramach badań teologicznych, jak niełatwe jest zrozumienie, czym właściwie jest tenże zmysł. Tym, co utrudnia zrozumienie tej rzeczywistości związanej z wiarą oraz jej uwzględnianie w prowadzonych badaniach teologicznych, jest najpierw traktowanie jej jako prostego synonimu określenia sensus fidei, gdy tymczasem nie jest to w pełni ścisłe, chociaż obie te rzeczywistości ściśle łączą się ze sobą. Jednostronne postawienie

1 Por. Międzynarodowa Komisja Teologiczna, Teologia dzisiaj. Perspektywy, zasady i kryteria, tłum. K. Stopa, Kraków 2012, s. 42-45 (nr 33-36).

2 Por. Y. M. J. Congar, Wiara i teologia, [w:] Tajemnica Boga, pr. zbior., PoznańWarszawa-Lublin 1966, s. 87-88; S. C. Napiórkowski, Jak uprawiać teologię?, Wrocław 1994, s. 106-108. 
na wewnętrzne i osobiste przeżycie wiary oraz sensus fidei sprawiają, że zagadnienie ujmuje się w perspektywie zbyt mistycznej, to znaczy łączy się ten sensus z całkowicie szczególnym poznaniem Boga, jakie ma miejsce w mistyce. Niejednokrotnie rozumie się sensus fidei jako mocno związany z tego rodzaju specyficznym poznaniem, przypisując mu jakiś rodzaj indywidualnej nieomylności w wierze. Owszem, pewna zbieżność, zwłaszcza w punkcie wyjścia, tych dwóch rzeczywistości ma miejsce, ale nie są one sprowadzalne do siebie. Natomiast druga trudność w rozumieniu sensus fidelium wynika na ogół z tego, że nakłada się na niego spojrzenie socjologizująco-demokratyczne, które zmierza do utożsamienia sensus fidelium z dominującym głosem opinii publicznej, a nawet proponuje odwołanie się przy jego weryfikacji do narzędzi wykorzystywanych w systemach demokratycznych, których podstawą funkcjonowania są głosowania i referenda. Uznaje się więc, że w sensus fidelium chodzi o jakieś wydobycie przekonania większości w jakiejś kwestii i uznania go za normatywne dla wszystkich. Owszem, już John Henry Newman napisał rozprawę, w której uzasadnia potrzebę prowadzenia konsultacji wśród wiernych w kwestiach doktrynalnych ${ }^{3}$ - rozprawa ta wywołała burzliwą dyskusję i wzbudziła podejrzenia pod adresem angielskiego konwertyty w Rzymie - ale także w tym wypadku trzeba powiedzieć, że nie jest to właściwa manifestacja sensus fidelium, ale co najwyżej jeden z jego przejawów i sposobów weryfikowania. Można by nawet postawić pozytywny postulat, by takie konsultacje miały miejsce w odniesieniu do nowych wyzwań, przed którymi staje doktryna i obyczaj kościelny, ale nigdy nie będzie to pełne urzeczywistnienie sensus fidelium.

Mimo tych zasadniczych trudności, a także wobec nich, kwestia zmysłu wiary i zmysłu wiernych domaga się podjęcia, biorąc pod uwagę oczekiwania kościelne, tym bardziej że w wielu środo-

3 Por. J. H. Newman, On consulting the faithful in matters of doctrine, [w:] Conscience, concensus and the development of doctrine. Revolutionary texts by John Henry Cardinal Newman, ed. by J. Gaffney, New York 1992, s. 392-428. 
wiskach zagadnienie jest żywo dyskutowane ${ }^{4}$. Aby jednak to podjęcie było owocne, zachodzi potrzeba adekwatniejszego opisania tych dwóch rzeczywistości na tle odpowiednio zarysowanego rozumienia Kościoła. Dopiero na tym tle będzie można powiedzieć coś sensownego o możliwościach włączenia zmysłu wiary i zmysłu wiernych do pracy teologicznej.

\section{KOŚCIÓŁ JAKO PODMIOT WIARY}

Aby zatem móc sensownie mówić o sensus fidei i sensus fidelium, konieczna jest przynajmniej ogólna refleksja na temat Kościoła i eklezjalnego wymiaru doświadczania wiary chrześcijanina, ponieważ sensus w obydwu znaczeniach jest właściwie przejawem integralnego przeżywania wiary, którego koniecznym aspektem jest jej eklezjalność. Nie jest to tylko kwestia jakiegoś osobistego odczuwania i doświadczania w wierze, ale zwłaszcza sensus fidei jest czymś w rodzaju głębszej sprawności nadprzyrodzonej, warunkowanej pełnym rozwojem wiary, a ta jest i może być tylko eklezjalna w swoim zakorzenieniu i w swoim wyrazie.

Kościół jest więc wspólnotą organicznie uporządkowaną, która odznacza się pewną określoną podmiotowością, pozwalającą widzieć go jako pewne całościowe my, dzięki któremu zmierza do pełni religijnej każde ja wierzącego. Niewątpliwie wyróżniającą i kluczową dla tej wspólnotowości i podmiotowości właściwością Kościoła jest apostolskość. Oznacza ona, że Kościół nie tylko rozwinął się historycznie na fundamencie apostołów, ale że przez nich łączy się z osobą i misją Jezusa Chrystusa, Posłanego

4 Por. D. Vitali, Sensus fidelium. Una funzione ecclesiale di intelligenza della fede, Brescia 1993; Ch. Ohly, Sensus fidei fidelium. Zur Einordnung des Glaubenssinnes aller Gläubigen in die Communio-Struktur der Kirche im geschichtlichen Spiegel dogmatisch-kanonistischer Erkenntnisse und der Aussagen des II. Vaticanum, St. Ottilien 1999; D. Burghardt, Institution Glaubenssinn. Die Bedeutung des sensus fidei im kirchlichen Verfassungsrecht und für die Interpretation kanonischer Gesetze, Paderborn 2002; G. Albano, Il sensus fidelium. La partecipazione del popolo di Dio alla funzione profetica di Cristo, Napoli 2008. 
Ojca, który zechciał być pośród ludzi jako ten, który służy, będąc Nauczycielem i Panem. Następujący po apostołach pasterze, pełniący zadanie powierzone przez Jezusa Chrystusa Proroka, Kapłana i Króla, zostają postawieni na czele owczarni, by służyć jak sam Chrystus, wydobywając i umożliwiając przeżywanie tego, co zasadnicze w Kościele, a więc tajemnicy zbawienia. Przypomnianą tutaj prawdę powtarza się nieustannie po II soborze watykańskim, ale mimo to ciągle traktuje się przedstawicieli hierarchii jako uprzywilejowane i najbardziej reprezentatywne wcielenie Kościoła. Prawda jest tymczasem zupełnie inna - hierarchia pełni tylko funkcję narzędziową w służbie celowi, który ją przekracza i który jest od niej większy i wznioślejszy, a którym jest utrzymywanie i wzrost w każdym z członków Ciała eklezjalnego i w całości tego Ciała życia łaski w komunii z Trójcą Świętą, które jest konkretnym i historycznym urzeczywistnianiem tajemnicy zbawienia.

Kościół, zgromadzony przez głoszenie Ewangelii, jest nowym ludem Boga Ojca, który go zamyślił przed wiekami i go prowadzi, od początku do końca, drogami, które On wyznacza i uznaje za najlepsze dla niego. Kościól jest także komunią w Duchu Świętym, który daje życie, uświęca w prawdzie, pozwala wyznawać Jezusa jako Pana oraz ufnie i po imieniu wzywać Ojca. Kościół jako całość jest poruszany przez Ojca i Ducha Świętego, ale w jedyny sposób należy on do Jezusa Chrystusa. Syn jest jedyną z osób Bożych, o której można powiedzieć, że Kościół jest Je go Ciałem. Nie tylko w sensie społecznym i moralnym, jakby to Ciało było zgromadzone tylko „pod znakiem” czy „w imię" Chrystusa kobiet i mężczyzn wierzących w Niego, ale przede wszystkim jest on Ciałem należącym organicznie do Jezusa Chrystusa w sensie mistycznym i realnym, to znaczy duchowym, a więc w sensie głębszym niż jakakolwiek inna przynależność, którą zna doświadczenie ludzkie. Słusznie podkreśla tradycja wywodząca się ze św. Tomasza z Akwinu, że w tym przypadku mamy do czynienia z quasi una mystica persona ${ }^{5}$.

5 Tomasz z Akwinu, Summa theologiae III q. 48 a. 2 ad 1. Szersza interpretacja formuły w: H. Mühlen: Una mystica Persona. Die Kirche als das Mysterium 


\section{EKLEZJALNE DOŚWIADCZENIE WIARY}

Aby móc przejść do naszego zagadnienia, nie wystarczy ogólne uznanie podmiotowości Kościoła, ale trzeba jeszcze zwrócić uwagę na sposób doświadczania tej podmiotowości i jej możliwości urzeczywistniania w życiu wierzącego. Wydaje się, że na czoło wysuwają się tutaj cztery elementy.

a. Pierwszy element ma charakter poniekąd bezpośredni czy też wprost socjologiczno-psychologiczny. Ponieważ rzeczywistość Kościoła w swojej ewidentnej widzialności jest pokrewna każdej innej zbiorowości ludzkiej, to znaczy ma charakter historyczny i socjologiczny, dlatego Kościół jest postrzegany i doświadczany przede wszystkim jako sieć wzajemnych relacji: z Bogiem, z innymi wierzącymi, z wszystkimi ludźmi, ze światem i jego sprawami. Są to relacje, które określają i poniekąd determinują podmiot wierzący w sytuacji zależności i współzależności, pozwalając zarazem rozwijać się i wyrażać posiadane potencjalności. Te relacje mają dla Kościoła także znaczenie fundacyjne, ponieważ wierzący, mając swoje źródło w Bogu i w Jezusie Chrystusie, wyraża się na sposób ludzki, a to ludzkie wyrażanie się stanowi także niezastąpiony wkład w utrwalanie i rozwój Kościoła widzialnego w dziejach. Jest to rzeczywistość sytuująca się na antypodach subiektywizmu czy też jakiegoś solipsyzmu duchowego.

b. Ten pierwszy, bezpośredni element doświadczenia eklezjalnego nie jest tylko jakąś formą nacisku na człowieka, ale sytuuje się on na poziomie osobistej wolności. Doświadczenie zawsze zakłada osobiste uczestniczenie w rzeczywistości (odniesienia, sytuacje, wydarzenia itd.), która jest jego przedmiotem. Gdy chodzi o najwyższą rzeczywistość Boga, w której zbiega się osobiste przylgnięcie wielu innych osób, kierowanych tym samym uczuciem wewnętrznym i osobistą decyzją, pojęcie uczestniczenia jawi się jako nieadekwatne i bardzo ograniczone. Dzisiaj chętnie mówi się w tym przypadku o ko mu nii, unikając tym samym pewnych trudności, ale pojęcie to

der heilgeschichtlichen Identität des Heiligen Geistes in Christus und den Christen. Eine Person in vielen Personen, Paderborn 1968. 
wskazuje przede wszystkim na rzeczywistość wewnętrzną, zawężając w znacznym stopniu to, co zewnętrzne. Niemniej jednak na tym gruncie następuje podjęcie i przemiana sieci relacji, o których wyżej była mowa. Przez komunię ze Świętym urzeczywistnia się komunia rzeczywistości świętych, a w ten sposób ludzkie doświadczenie doznaje pewnego rodzaju poszerzenia sięgającego w głąb, przede wszystkim w głąb wolności.

c. Trzeci element wpisany w ludzkie doświadczenia ma charakter intelektualny. Osoba zainteresowana doświadczeniem musi zwrócić się przez refleksję do tego, co przeżyła, a więc w jakimś stopniu zdystansować się w stosunku do swego przeżycia. Chodzi o to, by lepiej uświadomić sobie przeżywaną treść, aby następnie móc ją zinterpretować głębiej w świetle wiary. W ostatnim wieku chętnie stawiano postulat doświadczenia w teologii, widząc w nim sposób osiągnięcia tej głębszej interpretacji, a czyniono to zarówno na Wschodzie, jak i na Zachodzie ${ }^{6}$. To uświadomione przejście przez doświadczenie wypełniające się w kwalifikacji interpretacyjnej w oparciu o słowo Boże jest uzależnione od konkretnej osoby, od wykształcenia i zakresu innych jej doświadczeń, na przykład kulturowych i egzystencjalnych, od zdolności do introspekcji itd., ale wydaje się, że nie może być mowy o doświadczeniu osobistym bez pewnego przynajmniej stopnia osiągnięcia tego etapu o charakterze refleksyjnym. Doświadczenie nie jest prostą kwestią ilościową, ale ma raczej charakter jakościowy. Człowiek doświadczony to nie ten, który przeżył w ię c ej, ale który przeżył le piej i wniknął głę bi ej. Święty Bonawentura, nawiązując do doświadczeń duchowych św. Franciszku z Asyżu, zadaje następujące pytanie: „Bo czy warto wiele wiedzieć, a nic z tego nie zasmakować?"7. Święty Ignacy Loyola w Ćwiczeniach duchownych nawiązując do tego faktu, formułuje decydujące wskazanie: „Bo przecież nie obfitość wiedzy,

6 Por. P. Florenski, Христианство и култура, Москва 2001, s. 443-464.

7 Bonawentura, Konferencje o sześciu dniach stworzenia albo oświecenie Kościota $(22,21)$ przeł., zred. i wstępem opatrzył A. Horowski, Kraków 2008, s. 597: „Multa enim sire et nihil gustare quid valet?". 
ale wewnętrzne odczuwanie i smakowanie rzeczy zadowala i nasyca duszę"8.

Chrześcijanin wcielony do wspólnoty eklezjalnej żyje w niej w sposób owocniejszy, gdy umie rozpoznać to, co błędne, polepszyć to, co było dobre, przyjąć powołanie do świętości, to znaczy w świetle Ewangelii interpretować wszystkie swoje przeżycia, chwytając treść swoich doświadczeń. Przejście od uczestniczenia zewnętrznego do komunii wewnętrznej, o jaką chodzi w wierze eklezjalnej, domaga się więc refleksji, nawet jeśli pozostawałaby ona na bardzo podstawowym poziomie.

d. W tym miejscu pojawia się jeszcze czwarty element doświadczenia, który poniekąd stanowi jego wypełnienie, a dotyczy on wprost interwencji teologicznej. Doświadczenie chrześcijańskie, które - podobnie jak każde inne - jest przede wszystkim doświadczeniem indywidualnym, nie jest nigdy ściśle indywidualne. Wszyscy wierni odnajdują się we wspólnym i jedynym doświadczeniu Zmartwychwstałego. Wyrażając się w wielości doświadczeń indywidualnych, doświadczenie Kościoła jako wspólnotowego podmiotu wierzącego jest przedmiotem refleksji teologa, który na właściwym sobie poziomie opracowania interpretuje wszystko i ocenia w oparciu „o wiarę raz tylko przekazaną świętym” (Jud 3). Celem tej refleksji jest weryfikacja doświadczeń wypływających z wiary i ich obiektywizacja. Tylko na gruncie teologicznym można mówić o doświadczeniu chrześcijańskim jako organicznej całości doświadczeń jednostkowych, a nawet można je traktować jako miejsce teologiczne (locus theologicus). Jest oczywiste, że to miejsce teologiczne ma autorytet tylko w takiej mierze, w jakiej jest oparte na tradycji apostolskiej, ale może być ono zawsze inspirujące ze względu na aktualność takiego czy innego zagadnienia w życiu nowego ludu Bożego.

Starożytni mieli swój sposób mówienia o tej rzeczywistości, która została tutaj przedstawiona w sposób nieco fenomenologiczny, odwołując się do uprzywilejowanego dzisiaj pojęcia doświadcze-

8 I. Loyola, Ćwiczenia duchowne (nr 2), tłum. M. Bednarz, Kraków 1991, s. 6. 
nia. Już Orygenes mówił, że Kościołem jest każda dusza wierząca. Święty Grzegorz Wielki mówi o indywidualnym wierzącym zawsze w odpowiedniości z tym, co mówi o Kościele jako całości, przez co chce wskazać, że wierzący żyje w pełni tylko w Kościele, a tym samym on sam staje się Kościołem: „Hoc autem, quod generaliter de cuncta Ecclesia diximus, nunc specialiter de unaqu-

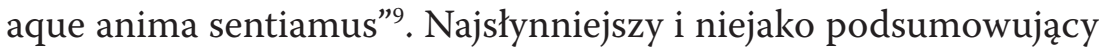
w ramach tej kwestii jest tekst, którego autorem jest Izaak z opactwa Stella: „Wszystko, co w pismach natchnionych przez Boga ogólnie powiedziano o Dziewicy-Matce, ogólnie też odnosi się do Kościoła, a szczególnie do Maryi. To zaś, co mówi się tam specjalnie o Dziewicy-Matce, Maryi, w ogólnym znaczeniu stosuje się również do dziewiczej matki-Kościoła; a to, co tam powiedziano o jednej z nich, dotyczy łącznie ich obu. Również i każda dusza wierna jest oblubienicą Słowa Bożego, jest matką, córką i siostrą Chrystusa. O każdej z nich można powiedzieć, że jest dziewicą, i to, że jest płodna. [...] Powiedziano następnie: «W dziedzictwie Pańskim mieszkać będę» (Syr 24, 11), gdyż dziedzictwem Bożym w powszechnym znaczeniu jest Kościół, w znaczeniu szczególnym jest nim Maryja, a w pojedynczym zastosowaniu - każda dusza wierna. W przybytku łona Maryi Chrystus gościł przez dziewięć miesięcy, w przybytku wiary Kościoła - aż do końca świata. W poznaniu i miłości wiernej duszy zostanie na wieki wieków"10.

\section{SENSUS FIDEI}

Wydaje się, że tak rozumiane doświadczenie eklezjalne w sposób szczególny urzeczywistnia się w ramach tych rzeczywistości, które

9 Grzegorz Wielki, In Canticum 15; [w:] G. Magno, Commento al Cantico dei cantici, Introduzione, traduzione e note a cura di A. Montanari, Milano 2012, s. 32 .

10 Izaak ze Stella, Sermo 61: PL 194, 1863B-1865C. Niezastąpione dla poznania tego bardzo ważnego zagadnienia są fundamentalne prace H. de Lubaca, w których wielokrotnie je podejmuje: Katolicyzm. Spoteczne aspekty dogmatu, tłum. M. Stokowska, Kraków 1988; Medytacje o Kościele, tłum. I. Białkowska-Cichoń, Kraków 1997. 
określamy jako sensus fidei i sensus fidelium. Wzajemna relacja tych pojęć pokazuje bardzo dobrze interakcję zachodzącą między czynnikiem subiektywnym i czynnikiem obiektywnym w relacji wierzącego do przedmiotu wiary, a tym samym rzuca znaczące światło na specyfikę teologii jako nauki oraz na jej eklezjalność i pastoralność. Rozróżnienie między zmysłem wiary i zmysłem wierzących ma także znaczenie dla opracowania wskazań dotyczących uwzględnienia tych dwóch rzeczywistości w teologii.

Sensus fidei oznacza przede wszystkim szczególną zdolność przenikania, która jest właściwa dla wiary przeżywanej w sposób pełny, to znaczy uformowanej przez miłość i doskonalonej darami Ducha Świętego, a tym samym w najwyższym stopniu potwierdzającą swoją eklezjalność. Chodzi o zdolność nadprzyrodzoną, wyrażającą się w intuicji, dzięki której wierzący spontanicznie i niejako instynktownie (instinctus fidei) rozróżnia to, co należy do wiary, od tego, co do niej nie należy. W tym wypadku wewnętrzne i głębokie poznanie nie tylko jest dawane przez przenikliwość inteligencji, ale raczej przez czystość serca i w większym stopniu zależy od konkretnego doświadczenia niż od wysiłku intelektualnego, który wprawdzie towarzyszy wierze, ale jej nie determinuje.

Chcąc lepiej zrozumieć, o co tutaj chodzi, trzeba odwołać się do idei poznania per connaturalitatem ${ }^{11}$. W ostatnim czasie zwróciła ona uwagę teoretyków poznania, i to nie tylko teologicznego. Przede wszystkim mamy z nią do czynienia na poziomie życia potocznego, zwłaszcza w relacjach międzyosobowych, oraz na poziomie życia duchowego, a nawet mistycznego. Jest to poniekąd poznanie „przez podobieństwo" w stosunku do osób, które się kocha, poznanie typu doświadczalnego, poznanie przeżywane, którego nie można wyrazić w sposób pełny na poziomie teoretycznym i logicznym, ale które jest o wiele bogatsze i cenne niż poznanie za pośrednictwem idei czy pojęć ogólnych. W tym szczególnym typie poznania serce wyprzedza rozum i niejednokrotnie sięga o wiele dalej. W kwestiach

11 Por. M. D’Avenia, La conoscenza per connaturalità in S. Tommaso d'Aquino, Bologna 1992. 
religijnych mówi się w tym kontekście o „oczach wiary” 12 i „oczach umysłu"13.

Wiara, która w swoim najpełniejszym znaczeniu łączy się z takim poznaniem i z miłością, którą Bóg rozlewa w sercach wierzących (por. $\mathrm{Rz} 5,5$ ), dostarcza poznania tego właśnie typu. Będąc darem Bożym, wprowadza w zażyłość z Bogiem i kształtuje ją, tak że tylko ten, kto jest pod jej wpływem, osiąga takie poznanie rzeczywistości Bożych, których refleksja intelektualna nie mogłaby mu dać.

Można przytoczyć długą listę świadków, którzy mówią o tego typu poznaniu, urzeczywistniającym się w ramach wiary chrześcijańskiej. Święty Augustyn poucza swoich wiernych: „Nie jakakolwiek wiara, lecz ta wiara, która działa przez miłość. Miej ją, a naukę zrozumiesz”"14. A w innym miejscu: „Wzrastajcie w miłości, która rozlewa się w sercach waszych przez Ducha Świętego, który wam jest dany. [...] Nie miłuje się bowiem tego, czego wcale się nie zna. Jeśli się zaś miłuje to, co się nieco zna, to ta miłość sprawia, iż można to poznać coraz lepiej i coraz pełniej" ${ }^{15}$. Święty Tomasz z Akwinu, nieustannie posądzany o przerosty intelektualistyczne, $\mathrm{w}$ takim samym znaczeniu komentuje słowa św. Pawła z Listu do Filipian: „A modlę się o to, aby miłość wasza doskonaliła się coraz bardziej w poznaniu i wszelkim wyczuciu dla oceny tego, co lepsze" $(1,9-10)$. Akwinata podkreśla szczególny charakter tej wypowiedzi. W swoim komentarzu zwraca uwagę, że miłość przechodzi w poznanie, to znaczy inteligencja czyni z miłości narzędzie poznania oraz miłość daje inteligencji zdolność przenikania i rozeznania, które bez miłości nie byłyby możliwe ${ }^{16}$.

12 Por. P. Russelot, Les yeux de la foi, „Recherches de Science Religieuse” 1 (1910) s. 241-259, 444-475.

13 Por. II Sobór Watykański, konst. Dei Verbum, 5.

14 Augustyn, In Ioannis Evangelium tractatus 29, 6: PL 35, 1631.

15 Tamże, 96, 4: PL 35, 1876.

16 Por. Tomasz z Akwinu, Ad Philipenses 1, 9-10: Deinde cum dicit et hoc oro, etc., ponit deprecationem, et tria bona optat. Primo quantum ad interioris charitatis augmentum. Affectus enim interior perficitur per charitatem, et ideo non habenti charitatem optandum est ut habeat; habenti vero, ut perficiatur. Unde dicit ut charitas, et cetera. Pro augmento autem charitatis orandus est Deus, 
Sensus fidei jest więc pewnym wypełnieniem żywej wiary, co oznacza, że wierzący dzięki życiu poddanemu w pełni miłości Bożej, bez żadnego innego wysiłku odkrywa w sposób intuicyjny to, co jest zgodne z wiarą Kościoła, i to, co nie jest z nią zgodne. Kwestia poddania miłości Bożej ma w tym wypadku kluczowe znaczenie. Pomijamy tutaj szczegółowe zajmowanie się ta kwestią, ponieważ jej treść jest wystarczająco określona, na przykład w konstytucji Lumen gentium (por. $\mathrm{nr} 42$ ). W ten sposób wierzący osiąga pewność przeżywania swojej wiary i tego, co jest jej przedmiotem, chociaż nie jest w stanie tego wyjaśnić, a co pozwala mu zakwestionować nawet nauczanie zawodowych teologów i wychwycić błędy w przepowiadaniu. Jako przykład można podać św. Teresę od Jezusa. Gdy postępowała w drodze modlitwy i jej spowiednicy twierdzili, że w ramach tego postępu na coraz wyższym poziomie powinna coraz bardziej odsuwać się od świata zmysłowego oraz od człowieczeństwa Jezusa Chrystusa, ona bardzo szybko odkryła, że są to sugestie błędne, o czym przekonuje, odwołując się do osobistych „odczuć": "Choć niektórzy nie zgadzali się w tym ze mną i mówili, że tego nie rozumiem - gdyż są to drogi, po których sam nasz Pan prowadzi, i że wtedy, gdy już dusze wyjdą z tych początków, lepiej jest, aby zajmowały się sprawami bóstwa i unikały tych cielesnych - to jednak nigdy nie skłonią mnie do przyznania im racji, że to jest dobra droga.

quia solus Deus hoc in nobis operatur. II Cor. IX, 8: potens est autem Deus omnem gratiam abundare facere in vobis, ut in omnibus semper omnem sufficientiam habentes, abundetis in omne opus bonum, et cetera. Et hoc necessarium est ut petamus et nos, quia Matth. V, 20: nisi abundaverit iustitia vestra plus quam Scribarum et Pharisaeorum, non intrabitis in regnum caelorum. Secundo quantum ad intellectum. Unde dicit in omni scientia. Sed numquid ex charitate provenit scientia? Sic, quia dicitur I Io. II, 27: et vos unctionem quam accepistis ab eo, maneat in vobis, et non necesse habetis ut aliquis doceat vos, sed sicut unctio eius docet vos de omnibus, et cetera. Item, charitas est spiritus, de quo dicitur Io. XVI, 13: cum venerit ille spiritus veritatis, docebit vos omnem, et cetera. Cuius ratio est, quia qui habet habitum, si rectus est habitus, sequitur inde rectum iudicium de his quae pertinent ad illum habitum; si vero corruptus, falsum. Sicut circa venerea temperatus habet bonum iudicium, intemperatus non sed falsum. Omnia autem quae a nobis fiunt, sunt informanda charitate, et ideo habens charitatem, habet rectum iudicium, et quantum ad cognoscibilia. 
[...] Albowiem sam Pan mówi, że to On jest drogą; Pan mówi również, że jest światłem i że nikt nie może iść do Ojca, jak tylko przez Niego; i kto Mnie widzi, widzi mojego Ojca. Powiedzą niektóre z was, że te słowa mają inne znaczenie. Ja nie znam innych znaczeń, ale to jedno, które moja dusza zawsze odczuwa jako prawdę, przyniosło mi wiele dobra"17.

Oczywiście, w tym miejscu mogą pojawić się pytania, czy w podkreślaniu znaczenia sensus fidei nie zachodzi niebezpieczeństwo sprowadzenia wiary do uczucia tylko osobistego i uznania go za najwyższego sędziego w sprawach wiary. Czy nie jest to jakaś apologia subiektywizmu w kwestiach wiary, a więc bronienie czegoś zupełnie przeciwnego w stosunku do eklezjalnego wymiaru doświadczenia chrześcijańskiego? Odpowiedź na tę trudność sytuuje się właśnie po stronie eklezjalności wiary. Wspólnota kościelna, ujmowana w sposób organiczny, jest jedynym miejscem, w którym może wzrastać i rozwijać się sensus fidei, ponieważ wspólnota jest pośredniczką wiary i w niej weryfikuje się jej autentyczność. Fakt, że wspólnota jest pośredniczką w tej dziedzinie, ujawnia się natychmiast, gdy przystępujemy do spojrzenia na warunki przekazywania wiary z pokolenia na pokolenie. Oczywiście, u podstaw wiary znajduje się zawsze i pierwszorzędnie dar Boży, to znaczy wyrasta ona z czystej łaski, ale równocześnie to przekazywanie przywołuje zasadę, na którą kładzie nacisk św. Paweł: „Wiara rodzi się z tego, co się słyszy” (Rz 10, 17). Paweł, oczywiście, jest tylko sługą: „Lecz Bóg dał wzrost" (1 Kor 3,7$)$.

Ta pośrednicząca rola wspólnoty zostaje wydobyta jeszcze mocniej, gdy odwołamy się do nieco tajemniczej wypowiedzi, która zawsze jest przywoływana jako biblijna podstawa dla sensus fidei $i^{18}$. Pisze więc św. Jan: „Wy natomiast macie namaszczenie do Świętego i wszyscy jesteście napełnieni wiedzą. [...] Co do was, to namaszczenie, które otrzymaliście od Niego, trwa w was i nie potrzebujecie pouczenia od nikogo, ponieważ Jego namaszczenie poucza was

17 Teresa od Jezusa, Zamek wewnętrzny, czyli Mieszkania, tłum. D. Wandzioch, Poznań 2009, s. 217-218.

18 Por. II Sobór Watykański, konst. Lumen gentium, 12. 
o wszystkim, Ono jest prawdziwe i nie jest kłamstwem" (1 J 1, 20.27). Czy w takim razie, jeśli wierni nie potrzebują nikogo, kto by ich pouczał, nauczanie w Kościele nie jest zbędne?

Właściwe znaczenie tej wypowiedzi jest bardzo wymowne i egzegeza biblijna doszła do spójnego uchwycenia znaczenia tych słów ${ }^{19}$. Przede wszystkim podkreśla się, że ta wypowiedź nie jest wypowiedzią wyizolowaną w Piśmie Świętym - można w nim znaleźć wiele wypowiedzi, które mówią o tym, że Bóg naucza bezpośrednio w sercach wierzących ${ }^{20}$. W perspektywie wyznaczonej przez św. Jana trzeba wskazać trzy zbieżne elementy, które pozwalają wydobyć właściwe znaczenie przytoczonego tekstu:

a) Jan nie neguje konieczności nauczania zewnętrznego, ponieważ sam odwołuje się do niego (por. 1 J 2, 24; 4, 6; 2 J 9).

b) Trzeba pamiętać, że św. Jan często mówi o życiu chrześcijańskim, które osiągnęło doskonałość, nie wspominając, że w rzeczywistości chrześcijanie są jeszcze od niego odlegli. Stwierdza na przykład: „Ktokolwiek narodził się z Boga, nie grzeszy” (1 J 3, 9), co nie jest sprzeczne z tym, co powiedział wcześniej: „Jeśli mówimy, że nie mamy grzechu, to samych siebie oszukujemy i nie ma w nas prawdy. [...] Jeśli mówimy, że nie zgrzeszyliśmy, czynimy Go kłamcą i nie ma w nas Jego nauki” (1 J 1, 8.10). Trzeba więc mieć na względzie, że ten, w kogo wniknęło słowo Boże, czyniąc go doskonałym chrześcijaninem, spontanicznie rozróżnia to, co należy do wiary, a więc coraz mniej potrzebuje nauczania i prawa zewnętrznego. W tym jednak przypadku nauczanie nie zostaje wyeliminowane, ponieważ należy do samego pojęcia namaszczenia.

c) Pojęcie charisma, dosłownie oznaczające olej do namaszczania, stanowi centrum wyjaśnienia tego tekstu. Ignace de la Potterie wykazał, że chodzi w tym przypadku zarówno o słowo Chrystusa, jak i o działanie Ducha Świętego, i proponuje odnosić je do słowa Bożego, jednak nie jako otrzymywanego zewnętrznie przez przepowiadanie we wspólnocie, ale jako otrzymywanego

19 Por. I. de la Potterie, L'unzione del cristiano con la fede, [w:] I. de la Potterie, S. Lyonnet, La vita secondo lo Spirito, Roma 1992, s. 125-199.

20 Por. Jr 31, 31-34 (cyt. w: Hbr 8, 8-12), Jr 61, 1; Kol 1, 9; Flp 1, 9-10; Hbr 1,17-18. 
przez wiarę w sercach, w których pozostaje czynne dzięki działaniu Ducha Świętego. Innymi słowy, chodzi o „słowo Jezusa przyjęte w Kościele, ale które stopniowo zostaje interioryzowane w sercach wierzących pod wpływem Ducha Świętego. Dlatego nauczanie wewnętrzne i nauczanie zewnętrzne już nie przeciwstawiają się sobie - to nauczanie zewnętrzne, słowo Jezusa, jest interioryzowane w wierze"21.

\section{SENSUS FIDELIUM}

Ten nieco dłuższy wywód miał na celu pokazanie, że sensus fidei rozwija się tylko w łączności z wspólnotą kościelną i w relacji do nauczania przekazywanego w Kościele. Jeśli wierni mają zdolność rozróżniania tego, co prawdziwe, od tego, co fałszywe, dzieje się to dzięki słowu nauczania, które jest im głoszone "od początku”, to znaczy od chwili przyjęcia chrztu (por. $1 \mathrm{~J} 2,7 ; 3,11$ ). Dokonuje się to także dzięki posiadanej przez nich możliwości weryfikowania swojego sensus fidei z communis sensus fidelium, a właściwie $\mathrm{z}$ sensus Ecclesiae.

Analizowana wyżej rzeczywistość sensus fidei jest odnoszona przede wszystkim do osobistej wiary pojedynczego wierzącego, natomiast rzeczywistość sensus fidelium dotyczy wielości wiernych. Mówiąc jeszcze wyraźniej, chodzi o całość osób tworzących wspólnotę eklezjalną, a więc nie tylko sensus aliquorum fidelium, ale sensus omnium fidelium. W takim ujęciu sensus fidelium może być ujmowany jako zewnętrzna i wspólnotowa manifestacja sensus fidei. Jest to uzasadnione jeszcze bardziej, jeśli sięgniemy do doświadczeń historycznych, w których odwoływania się do zmysłu wiernych.

Przechodząc do omówienia rzeczywistości sensus fidelium, trzeba powiedzieć, że mamy w tym przypadku do czynienia z rzeczywistością pod pewnym względem statyczną - to znaczy wyrażoną zewnętrznie i podlegającą jakiemuś „zmierzeniu” - doświadcze-

${ }^{21}$ I. de la Potterie, L'unzione del cristiano con la fede, s. 167. 
nia teologalnego wspólnoty wierzących. To doświadczenie, ponieważ nie jest doświadczeniem jakoś wydzielonej osoby, ale raczej doświadczeniem kolektywnego podmiotu wierzącego, w którym w nowy sposób przebywa Duch Święty, broniący go przed jakimiś ustępstwami w dziedzinie wiary, stanowi uprzywilejowany punkt odniesienia dla Urzędu Nauczycielskiego Kościoła, dla teologów i dla poszczególnych wiernych.

Z tej też racji dla Urzędu Nauczycielskiego Kościoła i dla teologów sensus fidelium może stanowić „miejsce teologiczne”, do którego można się odwoływać, mając na względzie poznanie wiary Kościoła. Wystarczy tutaj przypomnieć, że w ciągu wieków wielokrotnie takie odwołanie się miało miejsce. Na przykład św. Augustyn odwoływał się do przekonania wiernych w polemice z pelagianami, a czynił to do tego stopnia, że Julian z Eklany oskarżał go, iż nadaje większe znaczenie opinii publicznej (populi murmur) niż argumentom ludzi wykształconych ${ }^{22}$. Papież Pius IX, ogłaszając dogmat niepokalanego poczęcia i Pius XII, ogłaszając dogmat wniebowzięcia Maryi, odwołali się w swoich decyzjach do argumentów zaczerpniętych $\mathrm{z}$ sensus fidelium.

Jakie są kryteria zgodności ludu Bożego w kwestiach wiary i obyczajów? Odpowiedź na to pytanie nie jest łatwa. Punktem odniesienia może być na pewno nauczanie II Soboru Watykańskiego. Zostało w nim sformułowane jasne pryncypium i przejrzyste są możliwości jego stosowania: „nadprzyrodzony zmysł wiary całego ludu" (sensus fidei totius populi) stanowi normę wiary dla każdej jednostki. Mówiąc konkretniej, oznacza to, iż poszczególny wierzący powinien weryfikować autentyczność swojej wiary i zajmowanej przez siebie postawy $\mathrm{w}$ relacji do innych wierzących $\mathrm{w}$ ramach wspólnot, do których należy: rodzina (ecclesia domestica), parafia, diecezja, różne grupy wiernych itd. Te wspólnoty, a właściwie szczególne manifestacje Kościoła, nie są oczywiście wszystkim, gdyż zależnie od środowiska, w którym żyją, mogą okazać się niebezpiecznie selektywne. Zachodzi więc potrzeba, aby pełne doświad-

22 Por. Augustyn, Contra Iulianum 1, 29 i 31: PL 44, 661-662. 
czenie Kościoła powszechnego było zawsze punktem odniesienia dla doświadczenia indywidualnego, by stawało się środowiskiem, w którym doświadczenie indywidualne jest przeżywane i które stanowi jego miarę. Chodzi więc o odnoszenie się w kwestiach wiary do wspólnot wierzących, do których się przynależy, mając oczywiście na względzie potrzebę odnoszenia się ostatecznego do Kościoła jako całości.

Tradycja chrześcijańska, opierając się na starożytnym przekonaniu, iż człowiek jest istotą polityczną, dokonała jej poszerzenia, podkreślając, że człowiek jest istotą społeczną, której możliwości samourzeczywistnienia wykraczają daleko poza polis, obejmując całą społeczność ludzką. W tym miejscu wystarczy wskazać na jeden aspekt tego poszerzenia, a mianowicie to, że człowiek nie może stać się sobą i w pełni się zrealizować inaczej, jak tylko w relacjach z innymi. Biorąc pod uwagę kontekst zmysłu wiernych, o którym mówimy, doświadczenie eklezjalne domaga się poszerzenia tego przekonania o eklezjalność bytu chrześcijanina - chrześcijanin jest i ma stawać się coraz bardziej istotą kościelną, wtedy uaktywni się również zmysł wiary całej wspólnoty kościelnej. Nie może być antropologii chrześcijańskiej, która nie zmierzałaby do osiągnięcia swego wypełniania w eklezjologii. II Sobór Watykański zwrócił na to bardzo dobrze uwagę, wydobywając w konstytucji Gaudium et spes społeczne i relacyjne aspekty teologii człowieka jako „stworzonego na obraz Boży", a w konstytucji Lumen gentium podkreślając wspólnotowy charakter zbawienia. W jednym i w drugim przypadku osoba jest pojęta w sposób relacyjny i komunijny, a urzeczywistniając tę relacyjność i komunijność, czynnie kształtuje zmysł wiary całości. Nie da się mówić o zmyśle wierzących tam, gdzie nie ma autentycznego przeżywania Kościoła. Oczywiście trzeba pamiętać, że kwestia przeżywania Kościoła, czyli egzystencjalnego wyrażenia tego, na co w Credo wskazuje artykuł: „Wierzę w jeden, święty, powszechny i apostolski Kościół”, stanowi jeden ze słabych punktów zwłaszcza duchowości katolickiej, mimo iż o Kościele tak wiele mówi się w doświadczeniu chrześcijańskim i w rozmaitych dziedzinach teologii praktycznej. Mamy w tym miejscu poważne wyzwanie, które staje zwłaszcza przed eklezjologią. 


\section{NIEKTÓRE SUGESTIE}

Na tle tego, co zostało tutaj powiedziane, można sformułować niektóre postulaty pod adresem teologii, która chciałby uwzględnić zarówno sensus fidei, jak i sensus fidelium w swoich poszukiwaniach. Jest to tym ważniejsze, że dokument Teologia dzisiaj, nadając podstawowe znaczenie tym kwestiom i ukierunkowując metodę dzisiejszych poszukiwań teologicznych, bardzo wyraźnie się tego domaga. Nie wchodzimy w kwestie szczegółowe - ograniczamy się jedynie do ogólnych postulatów treściowych, wychodząc z tylko sumarycznych uwag, które zostały zaprezentowane wyżej.

1. Jeśli chodzi o sensus fidei, należałoby przede wszystkim w większym stopniu zwrócić uwagę na szeroki zakres zagadnień dotyczących doświadczenia wiary, począwszy od doświadczeń potocznych, aż do doświadczenia mistycznego. Doświadczenia tego typu ukazują specyfikę wiary jako połączenia elementu obiektywnego i elementu subiektywnego. Szczególnym przejawem tego doświadczenia jest „teologia świętych”, na którą szczęśliwie zwraca się dzisiaj rosnącą uwagę ${ }^{23}$. W ramach tej problematyki na ciągłą uwagę zasługuje relacja między uprawianiem teologii i osobistą świętością teologa, która zdobywa sobie coraz szersze prawo obywatelstwa w ramach poszukiwań dotyczących natury i metody teologii ${ }^{24}$.

2. Jeśli chodzi o sensus fidelium, w poszukiwaniach teologicznych należałoby zwracać szerszą uwagę na doświadczenie wspólnot kościelnych, w których żyje i pracuje teolog. Dzięki temu pojawiające się zjawiska - zarówno pozytywne, jak i negatywne - zyskiwałyby konieczną dla ich rozwoju bądź wyeliminowania interpretację teologiczną. Sprzyjałaby ona wydobyciu wartościowych doświadczeń i intuicji, a zjawiska negatywne mogłyby być szybko korygowane. Niestety, ten aspekt poszukiwań teologicznych wciąż stanowi słaby punkt teologii rozwijanej w Polsce, na co zresztą zwracano już wielokrotnie uwagę. Wynika to być może z braku uczestniczenia

23 Por. F. M. Léthel, Connaître l'amour du Christ qui surpasse toute connaissance. La théologie des saints, Venasque 1989.

24 Por. H. U. von Balthasar, Teologia a świętość, s. 424-432. 
teologów w wierze wspólnot kościelnych, przy równoczesnym przeakcentowaniu funkcji osadzających teologa w stosunku do tej wiary.

3. Nie należy zapominać, że zachodzi potrzeba pogłębionych analiz natury zjawisk, którymi są sensus fidei i sensus fidelium, ponieważ pozostają one ciągle - jak zostało wyżej zaznaczone - mało zbadane. Zagadnieniem ogólniejszym, które jest konieczne, aby sensus fidei i sensus fidelium zyskały dowartościowanie i rozwinięcie w teologii, jest potrzeba pogłębienia teologii wiary, a zwłaszcza jej eklezjalności. Tylko adekwatne rozumienie tego zagadnienia otwiera na szerokie rozumienie zarówno eklezjalności teologii, jak również jej zaangażowania eklezjalnego, zwłaszcza związanego z odczytywaniem tego, co przeżywa pielgrzymujący Lud Boży i czego te przeżycia domagają się od teologa. 
ROZDZIAŁ XIII

\author{
米 \\ Teologia - Kościół - polityka. \\ Przemiany w samoświadomości \\ teologii
}

W historię teologii w XX wieku wpisuje się wiele specyficznych doświadczeń, przez które musiała ona przejść albo z własnego wyboru, albo pod naciskiem okoliczności zewnętrznych. Jest ich oczywiście wiele, tak że ich opisaniu poświęcono całe tomy udanych refleksji ${ }^{1}$. Na osobną uwagę wśród tych doświadczeń zasługują niewątpliwie te związane $\mathrm{z}$ kwestiami sytuującymi się na poziomie funkcji teologii. Idąc po linii św. Tomasza z Akwinu, teologia wyraża swoją podstawową świadomość w tym, że prezentuje samą siebie jako scientia salutis ${ }^{2}$. Oznacza to, że stawia sobie za cel nauczenie człowieka takiego sposobu patrzenia na Boga i człowieka, by odkrył on drogę prowadzącą go do zbawienia. Teologia w XX wieku, nie rezygnując z funkcji zbawczej wyznaczonej jej przez Akwinatę, zwróciła szeroką uwagę na to, że spełnia ona tę funkcję sytuując siebie samą, a zarazem swoją propozycję, jakby

1 Por. M. Schoof, Przełom w teologii katolickiej. Poczatki, drogi, perspektywy, tłum. H. Bortnowska, Kraków 1972; R. Winling, Teologia wspótczesna 19451980, tłum. K. Kisielewska-Sławińska, Kraków 1990.

2 Por. R. Latourelle, Teologia, scienza della salvezza, Assisi 1968. 
między dwoma biegunami, którymi są Kościół i świat. Zbawienie człowieka dokonuje się inaczej w ścisłej relacji z Kościołem, ale ten Kościół jest w ścisłej relacji ze światem. Aby więc teologia mogła pozostać wierna swojej podstawowej wizji jako scientia salutis, musi określić swoją pozycję wobec Kościoła i świata, a zarazem ciągle na nowo powracać do tego określenia ze względu na dojrzewającą samoświadomość Kościoła, jak i ze względu na zmieniającą się duchową sytuację świata.

Do podjęcia tych zadań dotyczących kształtowania swojej świadomości teologia doszła drogą rozbudowanej refleksji nad swoją naturą i metodą, ale dokonało się to również przy wydatnym wpływie czynników zewnętrznych, które mają nam wiele do powiedzenia także z tego względu, że dzisiaj mają one jakby swój dalszy ciąg i nie sposób pozostawić ich poza zasięgiem naszej refleksji. Jeśli chodzi o funkcję eklezjalną teologii, to na refleksję nad jej potrzebą i możliwościami zdecydowanie wpłynął II Sobór Watykański. W czasie obrad soborowych okazało się jak bardzo znaczącą rolę odgrywa teologia w rozumieniu rzeczywistości eklezjalnej, a następnie w formułowaniu propozycji duszpasterskich. Nie przypadkiem więc funkcja teologa - eksperta soborowego urosła do rangi pewnego symbolu ${ }^{3}$. Najlepiej widać to w tym, że właściwie wszyscy teologowie, którzy pełnili taką funkcję, po soborze dodają ten fakt do swoich biogramów jako zasadniczy element swojego curriculum teologicznego.

Doświadczenie soborowe eklezjalnej funkcji teologii stało się po soborze wspólnym dziedzictwem teologów. Wyraża się ono najpierw w refleksji nad eklezjalnym powołaniem teologa, eklezjalnością teologii i zadaniami Kościoła wobec teologii, a następnie w wierności doświadczeniu soborowemu, którego podstawowym wyznacznikiem jest „szukanie dalej”. Do takiej wierności teologii $\mathrm{w}$ formie napomnienia - wobec doświadczenia soboru zachęcał wkrótce po jego zakończeniu Yves Congar, jeden z najbardziej

3 Por. K. H. Neufeld, Vescovi e teologi al servizio del Concilio Vaticano II, [w:] Vaticano II: bilancio e prospettive venticinque anni dopo (1962-1987), red. R. Latourelle, t. 1, Assisi 1988², s. 82-109. 
wpływowych ekspertów soborowych: „Istnieje niebezpieczeństwo, że nie będzie się już szukać dalej, lecz tylko eksploatować niewyczerpany magazyn Vaticanum II. W ten sposób zostałaby otwarta era powatykańska, jak była swego czasu era potrydencka. Byłoby zdradą aggiornamento sądzić, iż jest ono raz na zawsze dokonane i zamknięte w tekstach Vaticanum II"4. Trzeba przyznać, że w znaczącej mierze teologia posoborowa pozostaje wierna temu napomnieniu, o czym świadczą zarówno nowe badania teologiczne, jak i udział teologów w głównych wydarzeniach eklezjalnych. Wielki Jubileusz 2000, w aspekcie zarówno przygotowania, jak i przebiegu, został naznaczony wieloma intensywnymi badaniami teologicznymi.

W XX wieku teologia przeszła także przez drugie ważne - niejednokrotnie także bardzo bolesne - doświadczenie, które można określić mianem doświadczenia politycznego. Zawsze było rzeczą wiadomą, że do chrześcijaństwa w sposób niejako wewnętrzny należy wymiar polityczny, ale w nowych okolicznościach wyłonionych w XX wieku okazało się w sposób bardziej bezpośredni, że także bycie teologiem nie jest zajęciem neutralnym, ograniczającym się do ścian biblioteki i auli akademickiej. Uprawianie teologii zakłada odniesienie do świata i życia, w tym także do sfery polityki, na zasadzie odpowiedzialności za nią i uczestniczenia w niej w sposób bezpośredni. Podstawowym doświadczeniem stało się w tym względzie pojawienie się w okresie międzywojennym ideologii totalitarnych, wśród których najbardziej zmuszającym do myślenia i udzielenia odpowiedzi stał się nazizm. Bodaj najbardziej wyartykułowane stanowisko w tej kwestii zajął Heinrich Schlier w referacie wygłoszonym do studentów teologii opowiadających się po stronie Bekennende Kirche, 4 stycznia 1936 roku, zatytułowanym: Die kirchliche Verantwortung des Theolgiestudenten ${ }^{5}$. Sama II wojna światowa jeszcze wyraźniej sformułowała pytanie do teologów o odpowiedzialność wobec rzeczywistości politycznej. Później doszły doświadczenia związane z innymi systemami totalitarnymi,

$4 \quad$ Cyt. za: M. Schoof, Przełom w teologii katolickiej, s. 253.

5 Por. H. Schlier, Der Geist und die Kirche. Exegetische Aufsätze und Vorträge, Freiburg-Basel-Wien 1980, s. 225-240. 
przede wszystkim z komunizmem, które również nie pozostały bez wpływu na kształt uprawiania teologii. Dzisiaj kwestia ma swoje przedłużenie, choć ciągle jeszcze jest zauważana tylko w niewielkim stopniu, w odniesieniu do liberalizmu.

Na gruncie tych doświadczeń politycznych wyłoniła się idea podjęcia i kształtowania poprzez teologię rzeczywistości społecznej i politycznej, która odnalazła się i uprawomocniła pod hasłem tak zwanej te ologi i polityc z nej, której twórcą jest Johann Baptist Metz $^{6}$. Mówiąc o teologii politycznej, trzeba oczywiście pamiętać, że chodzi w niej nie o bezpośrednie zaangażowanie polityczne teologa i teologii, ale o „zaproponowanie nowego rozumienia chrześcijaństwa w zależności od zagadnień wynikających z przemian, jakie zaszły, oraz nakreślenia zarysów teologii zdolnej objąć społeczny i polityczny wymiar ludzkiego istnienia"

Teologia polityczna rozwijana w ostatnich dziesięcioleciach ma na swoim koncie niewątpliwe osiągnięcia związane $\mathrm{z}$ interpretacją rzeczywistości społeczno-politycznej, ale trzeba także uczciwie stwierdzić, że nie zdołała uniknąć poważnych błędów, jak wspomniane zaangażowanie polityczne teologów oraz formułowanie teologii zaangażowanych politycznie, jak stało się to w przypadku „teologii wyzwolenia”. Poza tym także ta teologia polityczna, która odniosła pewne sukcesy, z biegiem czasu napotkała na szereg ograniczeń zarówno wewnętrznych, jak i zewnętrznych, tak że dzisiaj sam Metz mówi już o potrzebie poszukiwania „nowej teologii politycznej"8.

Po doświadczeniach, które stały się udziałem teologii w XX wieku w jej odniesieniu do Kościoła i polityki, pojawia się wciąż aktualne zadanie usystematyzowania jej relacji w odniesieniu do tych dwóch rzeczywistości jako dwóch biegunów jej refleksji, którą podejmuje

6 Por. J. B. Metz, Teologia polityczna, tłum. A. Mosurek, Kraków 2000. Por. także tenże, Zur Theologie der Welt, Mainz 1968; tenże, Glaube in Geschichte und Geselleschaft. Studien zu einer praktischen Fundamentaltheologie, Mainz 1977.

7 R. Winling, Teologia wspótczesna, s. 271.

8 Por. J. B. Metz, Sul concetto della nuova teologia politica, 1967-1997, Brescia 1998. 
jako scientia salutis. Tak postawiona kwestia zakłada najpierw postawienie pytania o to, czym jest teologia, by potem móc odnieść ją w sposób adekwatny do Kościoła i do polityki, określając jej pozycję i możliwe zadania w tym kontekście9 .

\section{CZYM JEST TEOLOGIA?}

Patrząc na historię kultury, dość łatwo dochodzimy do pewnego wniosku, że teologia jest właściwie zjawiskiem specyficznie chrześcijańskim, związanym ściśle z tą kulturą, która jest obecna tam, gdzie żyją chrześcijanie. Wprawdzie pojęcie teologii jest znane w kulturze przedchrześcijańskiej i w kulturach pozachrześcijańskich, ale nie urosło ono tam do rangi decydującego czynnika rozwoju religijnego - do rangi wydarzenia, powiedzielibyśmy dzisiaj. Dzieje się tak dlatego, że teologia rodzi się ze szczególnej struktury aktu wiary chrześcijańskiej, a mianowicie z tego, że ma ona jako integralny wymiar racjonalny. Szczególnym przykładem weryfikowania się i wpływowego oddziaływania tego zjawiska jest kultura europejska widziana zarówno w swojej odrębności w ramach kultur światowych, jak również w jej szczególnej pozycji zajmowanej w stosunku do tychże kultur. Ściśle mówiąc, teologia w sposób konieczny narodziła się na gruncie spotkania wiary biblijnej z racjonalnością grecką, która ma swoje początki już w Starym Testamencie, a na której historyczne chrześcijaństwo oparło się od samych swoich początków, czego wymownie dowodzi już Nowy Testament. Takie przeniknięcie się jest bardzo oczywiste choćby w Ewangelii św. Jana, gdy utożsamia on Jezusa Chrystusa ze Słowem. Stwierdzenie to wyraża dogłębne przekonanie, że z wiarą chrześcijańską ściśle łączy się kwestia racjonalności ${ }^{10}$. Można oczywiście iść dalej i powiedzieć - jak

9 W niniejszym opracowaniu podejmuję i rozwijam kwestie sformułowane przez kard. J. Ratzingera w artykule: Teologia a polityka Kościoła, zamieszczonym w jego książce: Kościót - ekumenizm - polityka, Poznań-Warszawa 1990, s. 201-211.

10 Por. E. Peterson, Was ist Theologie?, [w:] tegoż, Theologische Traktate, Würzburg 1994, s. 1-22. 
uczyniło wielu teologów już na początku chrześcijaństwa - że wiara chrześcijańska ma ścisły związek z Rozumem absolutnym i czystą Inteligencją. Stwierdzenie to chce także wskazać, że Rozum stanowi pierwotną i ostateczną podstawę bytu, a tym samym także rozum, którym posługuje się człowiek, nie jest przypadkowym i ubocznym produktem przemian, jakie nastąpiły w bezmiarze tego, co irracjonalne, które miałoby być początkiem wszystkiego, jak chce na przykład Marks. Wiara jako podstawowy akt chrześcijański wyraża więc i konstytuuje podwójne przekonanie: 1 . w wierze chrześcijańskiej wyraża się racjonalność, a więc domaga się ona rozumu jako miejsca, w którym mogłaby się manifestować; 2. rozum manifestuje się poprzez wiarę chrześcijańską, a więc racjonalność domaga się wiary jako swojej przestrzeni życiowej.

W teologii mamy więc do czynienia z relacją dialektyczną, której dwoma biegunami są rozum i wiara. Wynika z niej - z jednej strony - że na wierze chrześcijańskiej spoczywa istotne zadanie poszukiwania swojej racjonalności, a przez nią także racjonalności w ogóle ${ }^{11}$. Jednak - z drugiej strony - wiara powierza poszukującemu rozumowi zadanie doprowadzenia do uznania wiary za warunek umożliwiający jego działanie, by nie musieć zanegować swojego fundamentu, a tym samym nie skończyć w absurdzie. Zanegowanie takiej wiary prowadzi bowiem do zastąpienia rozum Bożego rozumem ludzkim, któremu brakuje podstaw dla jego racjonalności, a właśnie $\mathrm{w}$ ten sposób następuje wyeliminowanie komunikacji $\mathrm{z}$ rozumem Bożym, który stanowi dla niego źródło życia ${ }^{12}$. Innymi słowy, Bóg jest prawdą, w której uczestniczy każda prawda stworzona w człowieku i w świecie ${ }^{13}$.

W sytuacji dzisiejszego wyemancypowanego świata takie samoograniczenie się ludzkiego rozumu, czyli rezygnacja z jego prero-

11 O możliwościach interpretowania racjonalności wiary w aktualnym kontekście zob. w: S. Wszołek, Racjonalność wiary, Kraków 2003.

12 Kwestia ta bardzo dobrze jest widoczna w gnozeologii Tomasza z Akwinu i w gnozeologii scholastycznej. Por. J. Pieper, Wahrheit der Dinge (Eine Untersuchung zur Anthropologie des Hochmittelalters), München $1951^{6}$.

13 Por. Tomasz z Akwinu, Summa Theologie I a. 16; I a. 79 q. 4; I a. 84 a. 5. 
gatywy absolutności i samowystarczalności, może być uznane za przejaw wstecznictwa, a nawet reakcyjności. Jednak to nie kto inny, ale właśnie Max Horkheimer i Theodor W. Adorno w swoich słynnych analizach dialektyki oświecenia wykazali, że takie samoograniczenie musi zostać przyjęte przynajmniej jako ogólna perspekty$\mathrm{wa}^{14}$. Oświecenie opiera się na „dogmacie”, że prawda ma charakter absolutny i boski. Jeśli jednak nie uznaje ono niczego więcej poza tym swoim pierwotnym warunkiem i rozciąga swoją absolutność poza założoną absolutność prawdy, to wtedy - na mocy swojej logiki wewnętrznej - na nowo uzasadnia to, co irracjonalne, oraz sprowadza rozum do przypadku, który wyłonił się z tego, co irracjonalne, a tym samym sam rozum staje się irracjonalny.

Aby to zweryfikować, wystarczy w tym miejscu zastosować proste rozumowanie: jeśli początek świata jest wynikiem samego pierwotnego wybuchu, to znaczy bez udziału przyczyny transcendentnej, to wtedy już nie rozum stanowi kryterium i podstawę rzeczywistości, ale właśnie to, co irracjonalne. W takim przypadku także rozum musi zostać uznany za irracjonalny i uboczny produkt tego, co irracjonalne, a więc wszystko zostaje sprowadzone do „przypadku i konieczności”, a nawet do „błędu”. Oznacza to, że ostatecznie także on sam jest irracjonalny. Nie jest się w takim przypadku w stanie zrozumieć, dlaczego właśnie rozum powinien zostać uznany za stałe kryterium i ostateczną instancję rzeczywistości i działania, skoro on sam podlega temu, co irracjonalne, a więc nie może pretendować, by zawsze i wszędzie funkcjonować w oparciu o takie same określone wcześniej prawa ${ }^{15}$.

Jeśli chodzi o teologię, to trzeba przede wszystkim stwierdzić, że opiera się ona na płynącym z wiary założeniu, iż przedmiot wiary, to znaczy jej punkt wyjścia i jej podstawa, jest racjonalny, a nawet jest samym Rozumem. Wynika z tego, że zadanie wiary polega na dążeniu do rozumienia jej podstaw i jej treści. Właśnie to dążenie

14 Por. M. Horkheimer, T. W. Adorno, Dialektyka Oświecenia, tłum. M. Łukasiewicz, Warszawa 1994.

15 Szerzej na ten temat w moim opracowaniu: Credo. Przedmiotowe wymiary aktu wiary, Tarnów 2002, s. 193-204. 
jest teologią - fides quaerens intellectum. Ściślej mówiąc - teologią jest taki wysiłek rozumienia, który dokonuje się w formie uporządkowanej oraz opiera się na logicznych i spójnych zasadach, czyli jest metodyczny. Teologia podejmuje więc podstawową kwestię filozofii greckiej, a mianowicie kwestię bytu, a więc i kwestię prawdy. Teolog chrześcijański zajmuje się nie tylko interpretacją tekstów $\mathrm{w}$ aspekcie filologicznym i historycznym, ale przede wszystkim podejmuje poszukiwania mające na celu sięgnięcie do samej prawdy, a ludzi traktuje jako zdolnych do jej poznania. W tym wyrażaja się wielkość i humanizm teologii, której zagraża rozpowszechniony dzisiaj historyzm ${ }^{16}$, a także jej otwartość na spotkanie z mentalnością oświeceniową.

Mimo możliwości pozytywnego otwarcia pojęcia oświecenia jawi się ono jako pojęcie problematyczne. Pozostaje faktem, który weryfikuje się w dwóch ostatnich stuleciach, że im bardziej oświecenie - $\mathrm{w}$ różnych formach - rozwija się $\mathrm{w}$ historii, tym bardziej zostaje zawężone pojęcie rozumu. W nurcie interpretacji pozytywistycznej, która dzisiaj jest bardziej rozpowszechniona, niż się to na ogół wydaje, za racjonalne uznaje się to, co jest „odtwarzalne” na gruncie eksperymentu. W ten sposób zakres jego poznania zostaje sprowadzony do tego, do czego dochodzą nauki przyrodnicze, w których odtwarzanie wyników poznania jest zasadą ich badań Konsekwencją tego pozytywistycznego ujęcia jest jednak rezygnacja z pierwotnej kwestii poznania ludzkiego, kryjącą się za pytaniem: "co to jest?". Zamiast tego pytania pojawia się wszechogarniające pytanie: ,jak to funkcjonuje?", które zostaje uznane za jedyne pytanie, do którego zadawania jest uprawniony rozum ludzki. W takim redukcyjnym ujęciu rozum rezygnuje z kwestii prawdy, ograniczając się jednostronnie do kwestii „faktyczności”. Jest to zatem sytuacja, w której rozum ustępuje miejsca pragmatyzmowi, oddalając się od kwestii metafizycznych. Bardzo wymowny jest w tym

16 Jeśli chodzi o problem w odniesieniu do teologii, zob. H. L. Ollig, Perspektiven des Historismusproblem, [w:] Dogmengeschichte und katholische Theologie, hrsg. von W. Lösser, K. Lehmann, M. Lutz-Bachmann, Würzburg 1985, s. 37-77. 
względzie sąd nad naszą epoką wyrażony przez Jeana Daniélou: „Nasze społeczeństwo nie jest niemoralne - w każdym razie nie jest takim bardziej niż inne - grzeszy raczej przeciw inteligencji. Największymi grzesznikami naszych czasów są często intelektualiści. Są bardziej winni niż kapitaliści, ponieważ tym, co nadwerężają, tym, co burzą, szczególnie w młodych [...] jest fundamentalna idea, że istnieje wymiar rzeczywistości, który nas przekracza, i że inteligencja może ją uchwycić"17.

Bardzo wyraźnie widać wpływ myślenia oświeceniowo-pozytywistycznego, gdy spojrzymy na interpretacje, jakie zaproponowano w ostatnim stuleciu w odniesieniu do tej najwyższej instytucji naukowej, jaką jest uniwersytet. Oczywiście specyfika tych interpretacji staje się wyraźniejsza, gdy usytuujemy ją w perspektywie historycznej. Uniwersytety powstały w średniowieczu, a więc wtedy, gdy wiara w sposób najbardziej radykalny deklarowała, że jest możliwe poszukiwanie prawdy, i prowadziła człowieka wierzącego do takiego poszukiwania, które najpierw wyraziło się w tworzeniu wydziałów teologii, a potem zostało rozciągnięte na inne dziedziny poznania ludzkiego, które stopniowo się kształtowały, tak że z biegiem czasu zaczęły powstawać coraz to nowe wydziały $^{18}$. Jest jednak bardzo charakterystyczne dla przedoświeceniowych uniwersytetów to, że mimo różnych przedmiotów, których badaniami zajmowały się poszczególne wydziały, wszystkim im było wspólne zadawanie, jako podstawowego, pytania o prawdę, zapewniające im trwałość i własne miejsce w strukturze uniwersytetu. Ostateczną gwarancją możliwości poznania prawdy był - co uznawały wszystkie wydziały - wydział teologii. Ponieważ wszelkie poznanie ludzkie zostało ściśle złączone z jednością jego podstaw, dlatego wszyscy - uczeni i ci, który chcieli stać się nimi - stanowili jedną universitas. Można więc powiedzieć, bez bycia posądzonym o zbytnią pretensjonalność, że uniwersytet wyrósł z poważnego podjęcia zadania powierzonego rozumowi przez akt wiary chrześcijańskiej. Gdy ta geneza uniwersytetu i ten jego fundament nie

17 J. Daniélou, Memorie, Torino 1975, s. 21-22.

18 Por. J. Verger, Les Universités au Moyen Age, Paris 1973. 
jest wszechstronnie brany pod uwagę $\mathrm{w}$ spojrzeniu na jego naturę i funkcjonowanie, mają miejsce rozmaite kryzysy, którym już wielokrotnie musiały stawić czoła instytucje uniwersyteckie. W historii uniwersytetów najpoważniejsze kryzysy miały więc miejsce wtedy, gdy znikało z nich pytanie o prawdę jako kwestia nienaukowa. W takiej sytuacji uniwersytet zostaje podporządkowany pozytywistycznemu sposobowi poznania, tak że zamiast zasady jedności wiedzy rządzi nim wąskie kryterium specjalizacji, które - owszem zostaje rozwinięte ze skrajną konsekwencją, ale bez odniesienia do kwestii prawdy.

Nie dziwi więc, że w okresie powojennym, gdy rozpowszechniła się taka wizja uniwersytetu, powszechnie opowiedziano się w środowiskach akademickich za ideologią marksistowską, którą wprawdzie krytykowano, ale - wbrew pozorom - była to krytyka immanentna, a więc niemająca szerszych perspektyw i możliwości zaproponowania jakiejś alternatywy ${ }^{19}$. Jako materializm ideologia marksistowska w punkcie wyjścia odrzuca prymat logo su, co oznacza, że w niej najbardziej radykalnie zostaje założone, że na początku nie ma rozu$\mathrm{mu}$, ale jest to, co irracjonalne. Rozum jest tylko jednym z produktów rozwijania się tego, co irracjonalne, a zatem jest on ostatecznie irracjonalny. Oznacza to, że rzeczy - jako irracjonalne - nie mają prawdy, a więc człowiek może arbitralnie ustalać prawdę. A skoro jest ona tworem człowieka, to w takim razie nie ma żadnej prawdy. Są tylko prawdy określone przez człowieka, a więc rozum zostaje rozbity na części, gdyż najpierw uznaje przymus rozwoju, który go poprzedza, a tym samym podnosi przymus do rangi wolności. Tutaj rozumie się sztandarowe hasło marksizmu, według którego „wolność jest uświadomioną koniecznością". Tym, co fascynuje w tych propozycjach, jest założone w nim prawo rozwoju i postępu, chociaż jest ono tylko prawem immanentnym, a więc pozbawionym wszelkich odniesień wykraczających poza system. W każdym razie

19 Taki charakter ma słynna krytyka marksizmu zaproponowana przez L. Kołakowskiego. Nie proponuje w niej żadnej alternatywy wobec tej ideologii, a więc być może także dlatego spotkała się z tak przychylnym przyjęciem w kręgach marksistowskich. Por. L. Kołakowski, Gtówne nurty marksizmu, Londyn 1988. 
tym, co tę konstrukcję spaja w jedną całość, umożliwiając pewne istnienie i funkcjonowanie uniwersytetu, jest konieczność partyjna, ale nie ma już w nim miejsca na wolność ${ }^{20}$.

Jeśli więc teologia podejmuje nie tylko wyjaśnienia dotyczące warunków historycznych, w których św. Jan powiedział: „Na początku było Słowo (= Rozum)", ale także wierzy w to stwierdzenie, uważa je za prawdę i na jego podstawie szuka prawdy, wtedy wkracza ona poza przyjętą wizję uniwersytetu, a więc nie ma dla niej tam miejsca. Jest więc naturalne, że broniąc się przed takim wykluczeniem, podejmuje ona zadanie dostosowania się do obowiązującej wizji, które - wbrew pozorom - wcale nie jest trudne. W takiej więc sytuacji także teologia, zamiast szukać prawdy w tekstach, na których opiera się jej istnienie, podejmuje wyjaśnienia warunków historycznych, w których powstały te teksty, dąży do rekonstrukcji ich pierwotnego znaczenia za pomocą metod historycznych oraz zestawia je krytycznie z wynikami wyjaśnień, które zostały wypracowane metodami historycznymi w badaniu innych tekstów. Oznacza to, że także ona może stanąć na wysokości zadania wyznaczonego przez rozum pozytywistyczny. Zostaje wtedy uprawniona tak samo jak inne dyscypliny, z tym że - niestety - rozmija się z tym specyficznym zadaniem, jakie początkowo zostało zarezerwowane dla teologii i filozofii, a mianowicie zadaniem poszukiwania jedności i całości poprzez usytuowanie się ponad różnymi dyscyplinami. Jest oczywiste, że w takiej sytuacji za najbardziej autentyczną teologię została uznana ta, która odwołuje się do praktyczności rozumu, którego celem staje się doprowadzenie do lepszego świata w przyszłości, czyli teologia zostaje ujęta jako rodzaj wiedzy praktycznej. Rozpowszechniony dzisiaj slogan, według którego ortopraksja powinna poprzedzać ortodoksję, narodził się w takich właśnie okolicznościach. To, co jest prawdziwe, powinno zostać zapoczątkowane przez człowieka i w tym celu filozofia praktyczna opracowuje

20 Kwestia ta jest bardzo szeroko obecna w nauczaniu papieża Jana Pawła II na temat uniwersytetu. Por. G. Tanzella-Nitti, Passione per la verità e responsabilità del sapere. Un'idea di università nel magistero di Giovanni Paolo II, Casale Monferrato 1998. 
sposoby działania, a teologia podporządkowuje się tej wizji. Jak daleko może sięgać to podporządkowanie, pokazuje następująca wypowiedź: „W obecnej sytuacji jesteśmy zmuszeni do rozwinięcia praktycznych modeli działania, nie mogąc oczekiwać pomocy ze strony ortodoksji. Wskazania ortodoksji są co najwyżej więzami [...] dlatego w miejsce ortodoksji związanej w swoich schematach ze strukturami społecznymi i z przekroczonymi kontekstami duchowymi - przynajmniej w chwili obecnej - powinna wyjść na pierwsze miejsce ortopraksja, która utrzymuje żywą wiarę i dostarcza nowej podstawy życia dla przekształcenia ortodoksji, która stała się bezpłodna i została wydziedziczona"21.

\section{KOŚCIÓŁ I TEOLOGIA}

Przedstawione zagadnienie wyjaśnia, w jaki sposób następuje skrajnie rozumiane przejście od teologii do polityki, a także ukazuje się wewnętrzna geneza wspomnianej teologii politycznej oraz pojawia się kwestia Kościoła. Kościół będzie oczywiście jawił się jako skażony reakcjonizmem wszędzie tam, gdzie proponuje on podjęcie kwestii prawdy. Na podstawie dotychczasowych refleksji okazuje się jednak oczywiste, że tam, gdzie tego pytania brakuje, człowiek zostaje wystawiony na działanie anonimowych sił lub podporządkowany konieczności partyjnej.

Aby uchwycić podstawowe znaczenie relacji między teologią i Kościołem, trzeba nawiązać jeszcze raz do struktury chrześcijańskiego aktu wiary. Wiara chrześcijańska potrzebuje rozumu i robi mu miejsce; jest ona przestrzenią życiową dla rozumu, tracącą swoją autentyczność, gdy nie określa się racjonalnie, ale zarazem także rozum pozbawia się swoich podstaw, gdy odrzuca wiarę bądź pomniejsza jej znaczenie. Przyjmując takie pryncypia, nie zakłada się oczywiście jakiegoś rozumu „abstrakcyjnego”, sytuującego

21 H. Halfbas, Linguaggio ed esperienza nell'insegnamento della religione, RomaBrescia 1970, s. 13-14. Por. także Th. Schneider, Orthodoxie und Orthopraxie. Überlegungen zur Struktur des christlichen Glaubens, "Thrierer Theologische Zeitschrift" 81 (1972), s. 140-152. 
się jakby poza uwarunkowaniami historycznymi i wspólnotowymi, gdyż takie ujmowanie rozumu słusznie mogłoby być krytykowane. Przeciwnie - zakłada się, że rozum funkcjonuje jako rozum, tylko uwzględniając warunki historyczne i społeczne, w ramach których jest usytuowany. Dlatego też wspólnota wiary, którą jest Kościól, należy do podstawowej struktury chrześcijańskiego aktu wiary oraz wpływa na kształt relacji wiary i rozumu. Kościół jest więc tą żywotną przestrzenią, w której jest możliwe urzeczywistnianie się wiary jako aktu wspólnotowego, a więc jest on także warunkiem historycznym, umożliwiającym rozumowi zadanie pytań, do których prowadzi wiara, a także utrwalającym jej dążenie do prawdy ${ }^{22}$. Jak pokazują osiągnięcia najnowszej gnozeologii, pytanie o racjonalność - z jednej strony - może być zadane tylko w sposób wspólnotowy i jako pytanie wspólnoty, która gwarantuje racjonalność rozumu; z drugiej strony - właśnie wspólnota musi postawić to pytanie, odwołując się do odpowiedzialności osobistej pytającego oraz musi ją podtrzymywać w dążeniu do udzielenia odpowiedzi ${ }^{23}$.

Zasadniczy problem, który należy rozważyć, polega na tym, że - jak mówią liczni współcześni krytycy Kościoła - jego relacja do nauki ma charakter ideologiczno-partyjny, ponieważ kieruje się on zasadą autorytetu. W konsekwencji między Urzędem Nauczycielskim Kościoła i teologią pojawiają się napięcia dwojakiego typu. Jeden rodzaj napięć wywodzi się z opowiedzenia się po stronie chrześcijaństwa rozumianego w kategoriach marksistowskich. Najbardziej radykalna interpretacja tego typu została zaproponowana być może przez Ernesto Cardenala, nikaraguańskiego poetę i teologa ${ }^{24}$. Uważa on, że istnieją dzisiaj dwa Kościoły: pierwszy będący narzędziem wyzwolenia i starający się w oparciu o humanizm marksistowski wprowadzić nowe społeczeństwo, będące Królestwem, oraz drugi, stanowiący oparcie dla obecnego

22 Por. moje opracowanie: Credo, s. 177-187.

23 Por. K. Rahner, Kleines Fragment "Über die kollektive Findung der Wahrheit", [w:] tegoż, Schriften zur Theologie, t. 4, Einsiedeln 1965, s. 104-110.

24 Por. E. Cardenal, La santitad de la revolución, Salamanca $1978^{2}$. 
społeczeństwa i będący w reakcji do tego nowego Kościoła ${ }^{25}$. Napięcie występuje w tym przypadku nie tyle między Urzędem Nauczycielskim Kościoła i teologią, ile raczej między dwiema formami realizacji Kościoła, w którym jednak Urząd Nauczycielski jest widziany jako ostoja Kościoła reakcyjnego. Drugi typ napięcia między teologią i Urzędem Nauczycielskim Kościoła opiera się na opisanym wyżej przekonaniu, według którego Urząd Nauczycielski jest widziany jako najwyższa instancja partyjna, która odwołując się do swojego autorytetu, usiłuje wiązać naukę z instancją pozanaukową, czyli z „ortodoksją”.

Nie można jednak zgodzić się z poglądem, według którego Kościół jest narzędziem całkowicie pozanaukowym w teologii ${ }^{26}$. Różnica między partią rozumianą ideologicznie i Kościołem jest widoczna w sposobie podejścia do kwestii prawdy. Materializm zakłada, że na początku nie ma rozumu, ale jest irracjonalna materia. Rozum jest więc wytworem tego, co irracjonalne - oznacza to, że prawda nie poprzedza człowieka, ale zostaje zapoczątkowana dopiero wraz z jego działaniem. Ortodoksja może więc być tylko dziełem ortopraksji, nawet jeśli opiera się na jakimś założeniu teoretycznym. Oznacza to, że prawda powinna utożsamiać się ze stanowiskiem partii i od niego zależeć.

Wiara chrześcijańska opiera się na przekonaniu dokładnie przeciwnym, a mianowicie - uznaje, że na początku jest Rozum, a więc człowiek rodzi się z prawdy i ona go kształtuje, a więc od niego pochodzi rozum uzdolniony do poznania prawdy. Człowiek jest przede wszystkim „odkrywcą” prawdy, a nie jej „twórcą". Wspólnota Kościoła stanowi oczywiście warunek historyczny dla aktywności

25 Co myśleć o takim ujęciu, przejrzyście wyraził Karl Rahner: „Byłem obecny we Frankfurcie, gdy Cardenal zadeklarował, że w Nikaragui zaczęło się królestwo Boże, nie istniały już więzienia, wszyscy się kochali... Z absurdem tego typu nie chcę mieć nic do czynienia" (K. Rahner, Confessare la fede nel tempo dell'attesa. Interviste, Roma 1994, s. 80). Te dotyczące teologii stwierdzenia nie kwestionują, że Cardenal jest rzeczywiście dobrym poetą, uznawanym za jednego z największych w XX wieku.

26 Por. K. Lehmann, Urzad nauczycielski a teologia, [w:] Podstawy wiary - teologia, s. 253-261. 
rozumu, ale Kościół nie utożsamia się z prawdą. Także Kościół nie jest twórcą prawdy, ale to on jest tworzony przez prawdę jako przestrzeń, w której dokonuje się jej poznanie. Prawda pozostaje więc zawsze niezależna od Kościoła, a Kościół istnieje jako na nią ukierunkowany. W tym miejscu ukazuje się autentyczna więź teologii i Kościoła, teologii i Urzędu Nauczycielskiego, jako rzeczywistości wzajemnie ukierunkowanych na siebie. Zadaniem Kościoła jest wyznaczanie granicy, poza którą teologia zdradza swoją żywotną przestrzeń, czyli zrywa więź z Kościołem, ale nie jest jej zadaniem wyznaczanie teologii - ponad podstawową strukturą wiary - treści, którymi ma się zajmować i metod, którymi ma się posługiwać. Ponieważ jednak ta specyficzna relacja zachodząca między Kościołem i teologią jest obca zarówno myśleniu pozytywistycznemu, jak marksistowskiemu, to znaczy dwóm dominującym dziś sposobom myślenia w nauce, istnieje realne niebezpieczeństwo zakwestionowania tej relacji $\mathrm{z}$ dwóch stron. $\mathrm{Z}$ drugiej jednak strony usytuowanie teologii w odniesieniu do tych dwóch współczesnych stanowisk jest konieczne dla ukazania autentycznego stanowiska chrześcijańskiego w interesującej nas kwestii.

\section{KOŚCIÓŁ I TEOLOGIA W DZIAŁANIU}

Po określeniu, czym jest teologia i jaka jest relacja Kościoła do teologii, można określić wzajemne odniesienia, które powinny istnieć między teologią i Kościołem w ich praktycznym oddziaływaniu na świat, w tym także na rzeczywistość polityczną. Aby móc dokonać takiego określenia, trzeba najpierw w sposób bardziej bezpośredni określić relację Kościoła do rzeczywistości politycznej w ogóle. Punktem odniesienia w tej kwestii pozostaje stwierdzenie Chrystusa: „Oddajcie więc cezarowi to, co należy do cezara, a Bogu to, co należy do Boga" (Mt 22, 21), które odegrało przełomową rolę w określeniu relacji między polityką i religiąa ${ }^{27}$. Do chwili jej pojawienia się powszechnie obowiązywała zasada, według której

27 O sensie i znaczeniu tej zasady, por. O. Culmann, Dio e Cesare, Roma 1996. 
polityk był uważany za postać sakralną. Państwo reprezentowało zasadę absolutną. To ono zapewniało obowiązywanie etyczne promulgowanych praw, a więc było gwarantem ich spójności, ponieważ prawa, a w nich także samo państwo, są wyrazem woli absolutnej - boskiej, a nie tylko czysto ludzkiej. Ponieważ zatem prawa mają charakter boski, dlatego bezwarunkowo obowiązują.

Wypowiedź Jezusa dokonała rozbicia w stałym, a nawet stopniowo pogłębiającym się procesie utożsamiania wymogów państwowych wobec ludzi z sakralnym wymogiem woli Bożej w stosunku do świata, przez co została zakwestionowana cała starożytna idea państwa. Jest więc zrozumiałe, że państwo starożytne uznało wprowadzanie tego rozbicia za atak na same podstawy swojego istnienia - atak karany śmiercią. Równocześnie jednak, jeśli należało uznać wypowiedź Jezusa za obowiązującą, to rzeczywiście państwo rzymskie w istniejącej wówczas postaci zostało skazane na zagładę. Trzeba jednak równocześnie zaznaczyć, że wprowadzenie rozdziału między władzą państwową i władzą sakralną, czyli ustawienie ich relacji w oparciu o zasadę dualizmu, wyznacza początek i stanowi trwałą podstawę zachodniej idei wolności ${ }^{28}$. Od chwili wprowadzenia tego rozdziału istnieją dwie wspólnoty wzajemnie ukierunkowane na siebie, ale nieutożsamiające się ze sobą; żadna $\mathrm{z}$ nich nie jest wszechobejmująca. Państwo zostało pozbawione autorytetu religijnego, który mógłby stanąć ponad sumieniem, zostając zmuszone do szukania fundamentu etycznego poza sobą. Odsyła więc do innej instancji. Kościół, jako ta instancja, traktuje siebie jako rzeczywistość etyczną, która opierając się na dobrowolnej przynależności, może stosować tylko sankcje moralne, a nie cywilne. $Z$ tego też powodu nie ma kompetencji nad państwem, które ma charakter pierwotny i jest wspólne wszystkim. Obydwie wspólnoty są więc ograniczone w zakresie swojego działania, a wolność opiera się na równowadze ich wzajemnego ukierunkowania na siebie.

28 R. Bultmann, Die Bedeutung des Gedankens der Freiheit für die abendländische Kultur, [w:] tegoż, Glauben und Verstehen. Gesammelte Aufsätze, t. 2, Tübingen 1952, s. 274-293. 
Stwierdzając zasadę ogólną, trzeba oczywiście powiedzieć, że ta równowaga była zawsze bardzo wątła, a nawet bardzo często burzona. Zarówno w średniowieczu, jak i na początku epoki nowożytnej bardzo często dochodziło do faktycznego pomieszania między państwem i Kościołem, zarówno z winy Kościoła, jak i z winy państwa. Efektem tego pomieszania, szczególnie na początku epoki nowożytnej, jest przede wszystkim niezrozumienie znaczenia wymogu prawdy w wierze, bardzo często mylonego z przymusem, który prowadzi do traktowania Kościoła jako instytucji totalitarnej.

Nowożytna idea wolności jest w każdym razie uprawnionym efektem chrześcijańskiego, dualistycznego spojrzenia na państwo, które mogło rozwinąć się tylko w środowisku, kierującym się zasadami chrześcijańskimi ${ }^{29}$. Praktycznie oznacza to, że tylko tam, gdzie istnieje $\mathrm{w}$ jakiejś formie dualizm między państwem i Kościołem, między władzą sakralną i władzą cywilną, tam jest spełniony podstawowy warunek, w oparciu o który można usankcjonować zasadę wolności. Tam, gdzie sam Kościół staje się państwem, tam wolność jest skazana na wyeliminowanie. Jednak także tam, gdzie Kościół zostaje zakwestionowany jako instancja znacząca w życiu publicznym, tam także zostaje zakwestionowana wolność, ponieważ w takim wypadku państwo znowu uzurpuje sobie przywilej stanowienia podstaw etyki. To drugie ujęcie znajduje dzisiaj przedłużenie w środowiskach zsekularyzowanych, gdyż w nich - idąc po linii państwa uzurpującego sobie przywileje absolutne - domaga się ono dla siebie absolutności nie w formie władzy sakralnej, ale w formie władzy ideologicznej, czyli państwo właściwie staje się partią. Uwzględniając to, że nie może mu się przeciwstawić żadna inna instancja, ponieważ została wyeliminowana, staje się na nowo państwem totalitarnym. Państwo ideologiczne staje się nieuchronnie państwem totalitarnym, a staje się ideologiczne, gdyż nie ma naprzeciw siebie żadnego wolnego i uznanego publicznie autorytetu. Brak dualizmu jest najprostszą drogą prowadzącą do totalitaryzmu.

29 Na temat kształtowania się tej idei w pierwotnym chrześcijaństwie, por. H. Rahner, Kościót i państwo we wczesnym chrześcijaństwie, tłum. M. Radożycka, Warszawa 1986. 
W oparciu o te rozważania musimy uznać, że podstawowym zadaniem Kościoła w polityce ma być troska o zachowanie równowagi systemu dualistycznego, stanowiącego podstawę wolności osobistej i politycznej. Kościół musi więc stawiać wymagania dotyczące prawa publicznego, a nie ograniczać się do kwestii związanych z prawem prywatnym. Dlatego też musi zachować wrażliwość na to, by Kościół i państwo były rzeczywistościami autonomicznymi, oraz na to, by przynależność do Kościoła miała zawsze charakter dobrowolny.

Przedstawiona tutaj relacja Kościoła i państwa rzuca ważne światło na kształtowanie wzajemnych relacji między Kościołem i teologią. Działanie Kościoła nie może być ukierunkowane na posiadanie władzy, gdyż mogłoby okazać się, że w ten sposób zagubi swoją podstawową treść, która ma charakter etyczny. Kościół musi kierować się w swoim działaniu poznaniem teologicznym, a nie maksymalnym pomnożeniem wpływów i władzy. Widać więc, że Kościół musi troszczyć się także o nadanie dualistycznej struktury swoim relacjom z teologią. Urząd Nauczycielski Kościoła nie może spełniać w stosunku do teologii roli kierownictwa partyjnego, które tworzy i aktualizuje ideologię nastawioną na zdobywanie władzy. Jego zadaniem jest służba Kościołowi, będącemu - jak zostało już powiedziane - żywotną przestrzenią, w której rozum poszukuje sensu. Właśnie z tej racji ma on - z jednej strony - upominać rozum przed dążeniem do abstrakcyjnej niezależności, będącej w gruncie rzeczy fikcją, a z drugiej strony - ma szanować specyficzną odpowiedzialność rozumu, który zadaje swoje pytania w żywym środowisku wiary.

Jak w przypadku wzajemnego ukierunkowania na siebie państwa i Kościoła, tak i w przypadku wzajemnego ukierunkowania na siebie Kościoła i teologii chodzi o zachowanie dualizmu, owocnego zarówno ze względu na Kościół, jak i ze względu na teologię. Tylko w takim przypadku będzie można uniknąć dwóch form błędnych relacji, które zasadniczo pojawiają się w tym przypadku. Pierwsza ma miejsce wtedy, gdy Urząd Nauczycielski Kościoła narusza autonomię teologii, pozostawiając jej tylko zadanie uzasadniania swoich urzędowych wypowiedzi. W takiej sytuacji teologia zostaje 
zdegradowana do rangi ideologii partyjnej. Druga błędna forma relacji weryfikuje się wtedy, gdy teologia pomniejsza Kościół bądź też gdy traktuje go jako instytucję pozbawioną wymiaru duchowego. W takim przypadku dystansuje się ona od duchowej podstawy, na której opiera się jako żywa wspólnota. Podmiotem teologii staje się wówczas pojedynczy badacz, a to oznacza, że zyskuje ona znamiona pozytywistyczne albo ideologiczne. Teologia rezygnuje więc z bycia teologią, ulegając samodestrukcji. Gdy jeden z dwóch biegunów relacji Kościół-teologia traci swoją własną autonomię, także drugi nieuchronnie traci swoją istotną treśćc ${ }^{30}$. Teologia nie może więc istnieć bez odniesienia do Kościoła, ale i Kościół nie może istnieć bez posługi teologii. Ta relacja, ze swej natury dialektyczna, jest także relacją krytyczną i wymagającą. Dopóki jednak będzie krytyczna, będzie także żywa i twórcza. Jeśli z kolei krytyczne będzie wzajemne oddziaływanie Kościoła i teologii, to owocne będzie również oddziaływanie Kościoła na sferę polityki.

30 Por. J. Ratzinger, Prawda w teologii, tłum. M. Mijalska, Kraków 2001, s. 117142. 


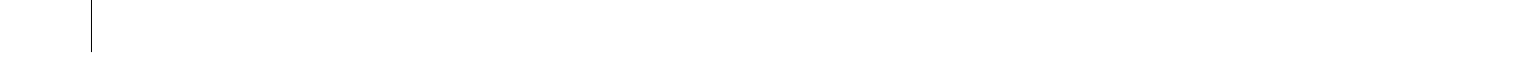


ROZDZIAŁ XIV

米

\section{Urząd Nauczycielski, teologia i katecheza. Wzajemne relacje w duchu komunii}

Magisterium in coelis habemus

Święty Augustyn ${ }^{1}$

Być może nadeszła godzina, w której chrześcijaństwo - nie pozwalając się już narzucać jako przykazanie moralne lub dogmat - mogłoby być zaproponowane jako motyw, jako zaproszenie, jako możliwość i konfiguracja stylu.

Elmar Salmann ${ }^{2}$

Od średniowiecza, które zaowocowało narodzinami teologii jako nauki, zaczął się w Kościele proces stopniowego rozwijania się specjalizacji poszczególnych posług eklezjalnych. Był to proces, który nieco wcześniej został zapoczątkowany także w społeczeństwie, szukającym dla siebie nowej struktury, nowych funkcji i nowych

\footnotetext{
Augustyn, Sermo 298, 5: PL 38, 1367.

2 E. Salmann, Presenza di Spirito. Il cristianesimo come gesto e pensiero, Padova 2000 , s. 5 .
} 
potrzeb w obliczu zmieniającej się sytuacji cywilizacyjnej i kulturowej. Poziom specjalizacji, z jakim mamy dzisiaj do czynienia, zarówno w dziedzinach profesjonalnych, jak i w dziedzinie funkcji społecznych, oraz powszechne domaganie się jego podnoszenia, przekroczył najśmielsze oczekiwania, jakie formułowano jeszcze kilkanaście lat temu. Ma to niewątpliwe zalety dla wzrostu skuteczności podejmowanych działań, ale równocześnie wywołuje ryzyko zredukowania coraz liczniejszych i coraz bardziej różnorodnych posług eklezjalnych do prostych funkcji profesjonalnych, które konkurują między sobą, a niekiedy nawet wzajemnie się kontestują ${ }^{3}$. W całkiem niedawnej przeszłości to ryzyko było mniejsze, gdyż żywsza była świadomość wewnętrznej jedności tego, co chrześcijańskie.

Dzisiaj, wraz z rozwojem struktur demokratycznych w społeczeństwie i wraz z poszukiwaniem autonomii dla własnych kompetencji, pojawiają się tendencje do podkreślania różnic między poszczególnymi posługami oraz rozwijają poszukiwania nastawione na przyznanie im jak najszerszej autonomii w dziedzinie praktyki. W związku z ciągłym rozwijaniem się tego procesu staje się coraz bardziej konieczny duch komunii, który każdej posłudze może dopomóc w odkryciu i uwzględnieniu własnego ograniczenia oraz doprowadzić do pokornego dowartościowania własnej specyficznej kompetencji przy równoczesnym szacunku dla innych i dla właściwej im funkcji związanej z pełnioną posługą. $\mathrm{Na}$ to zagadnienie zwrócił uwagę papież Jan Paweł II w liście apostolskim Novo millennio ineunte, zachęcając do krzewienia „duchowości komunii”. Pisze więc: „Należy krzewić duchowość komunii, podkreślając jej znaczenie jako zasady wychowawczej wszędzie tam, gdzie kształtuje się człowiek i chrześcijanin, gdzie formują się szafarze ołtarza, duszpasterze i osoby konsekrowane, gdzie powstają rodziny i wspólnoty”; a dalej: „Przestrzenie komunii należy kultywować i poszerzać

3 Nie przypadkiem zauważa się, że w wielu przypadkach grozi nam funkcjonalizm w sposobie traktowania i interpretowania posług eklezjalnych. Por. J. Ratzinger, Zur Frage nach dem Sinn des priesterliechen Dienstes, „Geist und Leben" 41 (1968), s. 347-376.

4 Jan Paweł II, list apost. Novo millennio ineunte, 43. 
każdego dnia i na wszystkich płaszczyznach życia poszczególnych Kościołów. Komunia powinna być wyraźnie widoczna w relacjach między biskupami, kapłanami i diakonami, między duszpasterzami a całym Ludem Bożym, między duchowieństwem i zakonnikami, między stowarzyszeniami i ruchami kościelnymi”"

Aby te wskazania mogły zostać wprowadzone w życie, zachodzi oczywiście potrzeba powołania do istnienia odpowiednich struktur, które będą sprzyjały wypełnianiu poszczególnych posług w Kościele, mając na celu wspólne dobro wszystkich wierzących. W niniejszych refleksjach zostanie zwrócona uwaga na relacje zachodzące między Urzędem Nauczycielskim, teologią i katechezą. Waga tego zagadnienia i pilna potrzeba jego podjęcia w ramach refleksji nad „dzisiejszym katechizującym” wynika przede wszystkim z tego, że katecheza, po wprowadzeniu nauczania religii w szkołach, znalazła się w nowej sytuacji, która - przynajmniej na poziomie praktycznym - spowodowała jej oddalenie od Urzędu Nauczycielskiego, a także od teologii. Wydaje się, że w wielu przypadkach kieruje się ona zbytnią autonomią w stosunku do innych form nauczania w Kościele. W związku z tym zachodzi potrzeba określenia własnych zadań, jakie spoczywają na Urzędzie Nauczycielskim, teologii i katechezie, oraz ustalenia relacji, jakie między nimi zachodzą, zwłaszcza tych, które ukazują ich jedność w ramach działalności nauczycielskiej Kościoła. Z kolei na tym tle będzie można sformułować propozycje dotyczące wzajemnego współdziałania między Urzędem Nauczycielskim, teologią i katechezą.

\section{URZĄD NAUCZYCIELSKI KOŚCIOŁA}

Do XIX wieku pojęcie „nauczanie” (magisterium) nie miało znaczenia technicznego, to znaczy odnoszącego się do oficjalnego, urzędowego i autorytatywnego nauczania w Kościele, głoszonego przez papieża i biskupów, czyli „urzędu nauczycielskiego"6. Było to poję-

Tamże, 45.

6 Por. Y. Congar, Eglise et papauté. Regards historiques, Paris 1994, s. 283-298 (rozdział: Pour une histoire sémantique du terme "magisterium”). 
cie ogólne, odnoszące się do różnych form nauczania w Kościele. Dzisiaj jest ono prawnie zarezerwowane dla papieża i biskupów, stając się synonimem „władzy” pasterzy we wszystkich spełnianych przez nich funkcjach: profetycznej, kapłańskiej i królewskiej (przepowiadanie, kult i dyscyplina). Byłoby w tym przypadku wskazane zastosowanie większej różnorodności określeń, a samo miano „urzędu nauczycielskiego” (magisterum) należałoby zarezerwować dla najwyższych form nauczania papieskiego.

Podstawowym zadaniem pasterzy jest bycie "przewodnikami” $\mathrm{i}$ „widzialną zasadą jedności”, także w dziedzinie nauczania wiary ${ }^{7}$. Konstytucja dogmatyczna Lumen gentium II Soboru Watykańskiego w numerze 25 określa odpowiedzialność biskupów wobec słowa Bożego (doktryny), a mianowicie podkreśla, że są oni głosicielami, świadkami i nauczycielami. Teologia wymaga od nas, by nie zatrzymywać się na tych określeniach, ale by szukać tego, co stanowi ich źródło i rację, ponieważ także poszczególni chrześcijanie - jako ochrzczeni - są powołani do tego, by byli głosicielami, świadkami i katechetami, a w niektórych przypadkach także nauczycielami, podejmując zadanie przepowiadania słowa Bożego. We wspomnianym numerze 25 znajdujemy wskazówkę dotyczącą tego, co specyficzne dla pasterzy i co nie przysługuje spełniającym inne posługi. Jest tam mowa o nich jako „autentycznych nauczycielach”, przy czym ta autentyczność oznacza „bycie obdarzonym władzą przez Chrystusa”. Ich nauczanie jest więc „autorytatywne”, ponieważ przemawiają na mocy władzy otrzymanej od Chrystusa oraz zostają uzdolnieni do reprezentowania i uosabiania wspólnoty, w której są pasterzami. W przypadku gdy są zebrani razem („kolegium zjednoczone pod papieżem", jak mówi II Sobór Watykański), są uzdolnieni do reprezentowania i uosabiania całego Kościoła. Nie oznacza to, że mają całkowicie przejąć i w sposób wyłączny zarezerwować dla siebie wszystkie funkcje odnoszące się do słowa Bożego, ale mają przewodzić i koordynować wszystkie funkcje w Kościele, aby on mógł w jedności żyć prawdą i dążyć do niej. W numerze 27

7 Por. F. Goyret, El obispo, pastor de la Iglesia. Estudio teológico del „munus regendi” en „Lumen gentium” 27, Pamplona 1998. 
konstytucji Lumen gentium jest mowa o biskupach jako „rządcach” domu Bożego, co oznacza ich podstawową i bezpośrednią odpowiedzialność za Kościół oraz spełniane w nim i przez niego posługi. Wykluczona zostaje w ten sposób możliwość - jaka niekiedy była praktykowana w Kościele - by biskupi ograniczali się do promowania i harmonizowania różnych posług, sami nie spełniając ich w sposób osobisty i bezpośredni.

W numerze 7 konstytucji dogmatycznej o Kościele zostało dokonane ścisłe zbliżenie roli władzy do funkcji „miłości” w Kościele. Konstytucja chce przez to wskazać, że na pasterzach spoczywa zadanie animowania życia Kościoła, także i przede wszystkim w odniesieniu do prawdy, słowa Bożego, wiary i nauczania wiary. W tym znaczeniu służą oni Duchowi Świętemu, który działa poprzez posługi i charyzmaty, aby Kościół jawił się jako budowany przez wszystkich chrześcijan jak przez „żywe kamienie” Ciała Chrystusa, oparte na „kamieniu węgielnym”, którym jest sam Chrystus (por. 1 P 2, 5) . $^{8}$

Autorytet pasterzy - jako autorytet nauczycielski - powinien odnosić się do „nauczania” wiary, ale zawsze uwzględniając, że to nauczanie odnosi się do żywych podmiotów, którymi są wierzą$\mathrm{cy}^{9}$. Nauczanie akademickie, uniwersyteckie nie stanowi dla niego wzoru, gdyż jego nadrzędnym celem jest budowanie obiektywnego systemu danych naukowych lub promocja badań ukierunkowanych bezpośrednio na rozwój wiedzy ludzkiej dotyczącej rzeczywistości. Władza pasterzy nie ma także inspirować się władzą funkcjonującą w społeczeństwach świeckich, dla której ma znaczenie, czy poddani wykonują jej polecenia, podczas gdy nie interesuje jej to, czy czynią to z miłością lub czy mają dobrą intencję. Kościół ma mieć na względzie formację sumień, dojrzewanie przekonań wewnętrznych i „poszerzanie” ducha, jak mówi św. Augustyn. Odnosi się to

8 Por. F. Schumacher, „Laßt euch als lebendige Steine zu einem geistigen Haus aufbauen" (1 Petr 2, 5), [w:] Ekklesiologie des Neuen Testaments. Für Karl Kertegle, hrsg. von R. Kampling, Th. Sönding, Freiburg-Basel-Wien 1996, s. 440457.

9 Por. A. Ziegenaus, Il vescovo, testimone e dottore autentico della fede, [w:] I Vescovi e il loro ministero, a cura di Ph. Goyret, Città del Vaticano 2000, s. $103-114$. 
przede wszystkim do nauczania wiary, a więc do wypełniania władzy pasterskiej w dziedzinie doktryny. Oczywiście, także pasterze nie mogą bezpośrednio wejść w wewnętrzny świat sumień, gdyż tam działa tylko Duch Święty, swoją mocą i swoim światłem. Jednak mają oni służyć Duchowi Świętemu, przekazując nauczanie, które jest zdrowym pokarmem dla ich wiary, oraz dając do dyspozycji określony język - nieodzowne narzędzie, które wspomaga komunikację wiary w ramach wspólnoty.

Wiara jest łaską, jaką daje sam Bóg i On wie, na ile zostaje przyjęta przez człowieka i staje się mocą jego życia. Jednak wiara zawsze zostaje wcielona w słowa i historyczne wyrażenia. Jest także dobrem społecznym, wspólną wartością, która utrzymuje się i rośnie w takiej mierze, w jakiej wierzący między sobą ją komunikują i przeżywają w jedności. Kościół nie jest czystą sumą wielu „ja wierzę” oddzielonych od siebie, jak proponuje schemat indywidualistyczny. Wiara jest wspólnotowym „my wierzymy”, czyli odpowiedzią dawaną Bogu przez wielkie „ja wierzę”, którym jest Kościół. Wiara każdego wierzącego powinna żyć w ramach wiary Kościoła; wiara Kościoła powinna natomiast żyć w ramach wiary każdego wierzącego. Tutaj sytuuje się rola Urzędu Nauczycielskiego w stosunku do wiary ${ }^{10}$.

$\mathrm{Na}$ tym tle nabiera wagi zagadnienie języka w znaczeniu „języka wspólnego", który pozwala wielu wierzącym zrozumieć słowo Boże, mówić o nim, komunikować wzajemnie własne doświadczenie wiary oraz zrozumieć się nawzajem. Urząd Nauczycielski ma za zadanie troszczyć się o wspólny język Kościoła, gdyż w przeciwnym razie nie byłyby możliwe ewangelizacja, katecheza, przekazywanie wiary. Urzędowi Nauczycielskiemu przysługuje więc bycie „autentycznym”, to znaczy „autorytatywnym”. W niektórych przypadkach przysługuje mu nieomylność, ale dzieje się tak tylko bardzo rzadko (ex cathedra). I Sobór Watykański określił ją w odniesieniu do papieża, a II Sobór Watykański w odniesieniu do wszystkich biskupów. Ma to miejsce, gdy zostają spełnione przynajmniej cztery warunki: - pasterze mówią jako pasterze, angażując swoją

10 Por. J. Królikowski, Credo. Przedmiotowe wymiary aktu wiary, Mielec 2002², s. $177-188$. 
władzę kościelną; - kierują nauczanie do całego Kościoła, czyli do wszystkich wierzących; - nauczanie dotyczy „wiary i obyczajów", czyli odnosi się do słowa Bożego; - jest podawane w sposób "ostateczny”, czyli rozwiązujący kwestie dotychczas dyskutowane. W każdym jednak przypadku pasterze pozostają wierzącymi. Wyrażają oni wiarę w imieniu wszystkich wierzących i w ramach komunii z nimi.

Jeśli pasterze mają troszczyć się o komunię, a więc o jedność wędrówki wiary wszystkich wierzących, to muszą otworzyć się na trzy wymiary czasu - na przeszłość, teraźniejszość i przyszłość. Kościół jest jeden i jedyny, o ile łączy w razem wszystkich wierzących w Chrystusa - tych, którzy na początku wierzyli w Niego, tych, którzy dzisiaj w Niego wierzą i tych, którzy będą w Niego wierzyli w przyszłości. Duch Święty asystuje Kościołowi, sprawiając, że w czasie i przestrzeni jest on rzeczywiście jedną rodziną Bożą - rodziną tych wszystkich, którzy zostali powołani, by stać się "synami w Synu”. Komunia świętych czyni współ-obecnymi wszystkich wierzących przeszłości i wszystkich wierzących przyszłości. Gwarancja trwania w prawdzie opiera się na zdolności pozostawania zjednoczonymi w wierze z tymi, którzy byli wcześniej, i z tymi, którzy przyjdą potem. W tym miejscu sytuuje się posługa pasterzy - wzywają oni wszystkich dzisiejszych wierzących do wierzenia tak, jak wierzyli bracia z minionych wieków. Wiara rozumiana jako doktryna, jako to, w co trzeba wierzyć - jest autentyczna wtedy, gdy pozostaje ta sama w ciągu wieków, by tworzyć jedno wielkie ja wierzące - ja wiecznego Kościoła.

Na drugim miejscu pasterze muszą troszczyć się o jedność wiary obecnie, czyli między członkami wspólnoty, w której każdy pasterz jest zasadą jedności oraz w taki sposób, aby każda wspólnota ze swej strony pozostała zjednoczona w wierze ze wszystkimi innymi wspólnotami świata, jakie dzisiaj istnieją na całym świecie. Także tutaj zachodzi niebezpieczeństwo przeżywania wiary w sposób indywidualistyczny, bądź - co najwyżej - w swoim własnym kręgu lub własnej wspólnocie. Tymczasem prawdziwa wiara polega na istotnym współ-wierzeniu - na wierzeniu wraz z wszystkimi braćmi rozproszonymi po całym świecie. Kardynał Joseph Ratzinger tak 
syntetyzuje to zagadnienie: „Nie ma wiary bez Kościoła. [...] Kiedy mówię: «ja wierzę», oznacza to, że przekraczam granice mojej podmiotowości, by zintegrować się $\mathrm{z}$ «ja» Kościoła, a równocześnie integruję się z jego wiedzą, przekraczając granice czasu. Akt wiary jest zawsze aktem, przez który wchodzi się w komunię z całością. Jest aktem komunii, przez który pozwalamy się zintegrować z komunią świadków, a w ten sposób przez nich dotykamy tego, co niedotykalne, słyszymy to, co niesłyszalne, widzimy to, co niewidzialne"11.

Pasterze muszą w końcu brać pod uwagę przyszłe pokolenia, pamiętając, że mają przekazać im wiarę czystą, która będzie stanowiła ożywczy pokarm ich życia. Dla niewierzącego problem przyszłości nie istnieje i - jak pokazuje dzisiaj zagadnienie ekologii rzeczywiście nie został on postawiony w przeszłości. Tylko wiara myśli o przyszłości. Wierzący musi myśleć o przyszłości, ponieważ wie, że Bóg powołuje po imieniu „to, co nie istnieje” i „to, co nie istnieje, traktuje tak, jakby już istniało". Urząd Nauczycielski ma za zadanie troszczyć się o komunię w wierze we wszystkich trzech wymiarach, aby jedność wierzących była pełna i aby Kościół trwał jako jeden i jedyny, mimo podziału na pokolenia wierzących, którzy żyli w przeszłości, którzy żyją obecnie i będą żyli w przyszłości. Jest prawdą, że taka troska dotyczy przede wszystkim sumienia każdego autentycznego wierzącego, ale komunia między przeszłością, teraźniejszością i przyszłością potrzebuje języka, który będzie jednoczył; potrzebuje rzeczywistej i skutecznej komunikacji, także za pośrednictwem znaków, gestów, postaw, świadectwa; potrzebuje odnosić się do czegoś obiektywnego, do wspólnej, jasnej i sprecyzowanej doktryny. Z kolei więź, jaka jednoczy wierzących w odniesieniu do doktryny i do całości znaków wiary, powinna być umocniona w sposób obiektywny, ale także zewnętrzny w stosunku do sumień, aby nie była uzależniona od arbitralnych decyzji jednostek; musi jawić się jako węzeł społeczny, coś widzialnego i zmysłowego. Tutaj otwiera się funkcja nauczania w Kościele.

11 J. Ratzinger, Przekazywanie i źródta wiary, s. 77. 


\section{TEOLOGIA}

Przez teologię rozumiemy tutaj teologię jako $\mathrm{n}$ a u kę, a nie tylko jakieś ogólne myślenie o wierze. Wskazuje się dzisiaj na duże znaczenie także tego ogólnego myślenia człowieka wierzącego, czyli teologii w sensie szerszym, ponieważ wiara ze swej natury domaga się związania z myślą zmierzającą do jej uzasadnienia. W każdym przypadku „wiara szuka rozumienia”. Teologia naukowa uwzględnia znaczenie pojęć i wypowiedzi doktrynalnych, ale trzeba także pamiętać, że jest równie dla niej ważne uwzględnianie tego, co każdy wierzący myśli o swojej wierze i jak przyjmuje jej treści. Jednak nie pomniejszając tego zagadnienia, zatrzymujemy się w tym miejscu na zagadnieniu teologii w sensie ścisłym, to znaczy na teologii naukowej ${ }^{12}$. Tak rozumiana teologia jest posługą bardzo związaną z Kościołem, którego członkami są poszczególni wierzący; w tym znaczeniu jej powołaniem jest nie tyle bezpośrednio służyć poszczególnym członkom Kościoła, ile nawiązać bezpośrednie relacje ze słowem Bożym, by na tej drodze uaktywnić działalność rozumu $\mathrm{w}$ relacji do rozumienia tego słowa, do jego interpretacji w kulturze, w jakiej żyją wierzący oraz do jego uzasadnienia wobec wymagań krytycznych rozumu ludzkiego ${ }^{13}$. Teologia podejmuje przede wszystkim zagadnienia nauczania wiary jako takiej, wiary w sobie, a dopiero drugorzędnie zajmuje się zagadnieniem wiary jako osobistym doświadczeniem ze strony osoby i wspólnoty; ma ona bardziej bezpośrednią relację z przedmiotem niż z podmiotem wiary. To nauczanie pasterzy i katecheza odnoszą się bardziej do podmiotu, który przyjmuje słowo Boże, który w nie wierzy i według niego żyje.

Oczywiście teolog tylko wtedy, gdy jest autentycznym wierzącym, a więc gdy przeżywa wiarę w sposób wspólnotowy w Kościele, może w sposób pełny realizować swoje własne powołanie. Jednak

12 O znaczeniu teologii w nowym kontekście eklezjalnym kulturowym, por. Glaubesissenschaft? Theologie im Spannungsfeld von Glaube, Rationalität und Öffentlichkeit, hrsg. von P. Neuner, Freiburg-Basel-Wien 2002.

13 O specyfice "zawodu” teologa w Kościele, por. L. Bouyer, Le métier du théologien, Paris 1979. 
jego specyficznym zadaniem jest uaktywnienie rozumu w stosunku do wiary. W ten sposób teolog staje także po stronie człowieka, który przyjmuje dar wiary oraz wydobywa wszystkie jego bogactwa duchowe i intelektualne, aby ludzka odpowiedź udzielana Bogu była pełna i adekwatna z punktu widzenia dojrzałości kulturowej wierzącego. W jego przypadku najpełniej weryfikuje się to, co mówi św. Paweł o autentyczności daru Ducha Świętego, a mianowicie, że dar Boży czyni autentycznymi ludźmi, łącznie z pogłębieniem ich racjonalności (por. 1 Kor 14, 14-20).

W tym znaczeniu teologia powinna mieć odniesienie do całej kultury, by doprowadzić ją do konfrontacji z nauczaniem wiary. Taka potrzeba wynika z faktu, że słowo Boże spełnia rolę oczyszczającą i podtrzymującą kulturę w jej wartościach pozytywnych, jak również z faktu, że kultura dostarcza wierze inspiracji i pomocy, by mogła ona wydobyć na zewnątrz ukryte w niej bogactwa. Każda kultura stanowi bowiem równocześnie ograniczenie i wartość dla wiary. Stanowi ograniczenie, ponieważ daje do dyspozycji jakiś określony horyzont czytania i interpretowania słowa Bożego; stanowi wartość, ponieważ te akcenty, które zawiera, stają się specjalnym punktem odniesienia, zwracającym uwagę na niektóre, często ukryte bądź pomniejszane aspekty słowa Bożego, przyczyniając się do budzenia wrażliwości i szczegółowych zastosowań. Dla zwrócenia uwagi na znaczenie tej wartości warto przytoczyć propozycję, jaką sformułował w tym względzie włoski filozof Luigi Pareyson: „Sytuacja historyczna powinna być przyjęta jako przedmiot stawiania problemu tak intensywnego, by uczynić z niej płonący tygiel formułowania prawdy wiecznej, a ta ostatnia powinna stać się obecnością, która tylko w tym nowym sformułowaniu jest rzeczywiście znacząca i mówiąca do człowieka dzisiejszego. Dzisiejszy chrześcijanin musi znaleźć nowy sposób uczasowienia tego, co wieczne, i uniknąć w ten sposób usztywnienia minionych sposobów uczasowienia w przyzwyczajeniach może wygodnych, ale już niemych i zmęczonych"14.

14 L. Pareyson, Essere libertà ambiguità, Milano 1998, s. 181. 
W pewnym sensie teologia sytuuje się trochę „przed” katechezą, a zarazem trochę „po” niej. Dotyczy to także każdej innej posługi eklezjalnej w stosunku do słowa Bożego. Chodzi o punkt widzenia chronologiczny i o uprzedzające badanie. Kultura, w której żyje wierzący, jest czymś złożonym i zmiennym (dzisiaj doświadczamy tego w sposób bardzo szczególny). Nie można kultywować iluzji niezmiennego świata. Konieczne jest dzisiaj podjęcie wszechstronnej „inkulturacji wiary”, czyli energiczne kształtowanie procesu wcielania wiary w kultury oraz dostosowywania jej języka do zmian następujących na poziomie języka ludzkiego. Zadanie to wymaga kompetencji, czasu i trudu. Zmieniają się dzisiaj nie tylko słowa, lecz także mentalność, wzory myślenia, wrażliwość, odczuwanie, a w związku z tym także spotkanie wiary z kulturą staje się coraz trudniejsze. I właśnie na tym polu ma działać teologia. Mimo niebezpieczeństw, jakie stają przed nią, jej misja jest konieczna. Teolog ma być pierwszym, który wchodzi - zanim zrobią to inni, a także w imieniu wszystkich wierzących - na nowe obszary kulturowe, by próbować w nowy sposób wyrazić jedną i jedyną wiarę Kościoła, by szukać nowego języka do mówienia o wierze i do przekazywania jej w ewangelizacji i katechizacji. Do podjęcia tego zagadnienia trzeba jednak pewnego „zamknięcia”, jakby laboratorium, by nie niepokoić wspólnoty wierzących przedstawianiem jej niedojrzałych i niesprawdzonych propozycji. Tylko roztropne działanie i poszukiwanie w ramach wspólnoty teologów może stać się w pełni owocne dla wspólnoty wierzących. Tylko na drodze powolnej weryfikacji formułowanych propozycji teologia sprawdzi się jako nauka eklezjalna oraz będzie mogła wnieść swój specyficzny wkład do misji duszpasterskiej Kościoła.

Urząd Nauczycielski i katecheza zakładają prawdę słowa Bożego i kierują się wrażliwością na jego odpowiedniość i wartość - prawda zostaje przekazana, aby była zbawcza tu i teraz dla tych osób i tych wspólnot. Na teologii spoczywa podstawowe zadanie krytycznej dyskusji nad prawdziwością różnych stwierdzeń dotyczących wiary i nad ich uzasadnieniem. Z tego punktu widzenia teologia poprzedza inne posługi - znaczenie, wartość, zastosowanie danych wiary wyłania się na drodze weryfikacji prawdy tych danych i ich 
interpretacji. W decydującym stopniu pozostaje prawdą, że „prawdę można tylko interpretować i nie ma innej interpretacji niż praw$\mathrm{da}^{\prime \prime}$. Teolog, podejmując się tego dzieła, staje się sługą pełniących rozmaite posługi. W sposób szczególny i najbardziej bezpośredni służy pełniącym posługi w stosunku do słowa Bożego w Kościele ${ }^{16}$.

\section{KATECHEZA}

Katecheza stanowi część działalności duszpasterskiej Kościoła. Jest to posługa dotycząca słowa Bożego, ale pozostaje ściśle związana z żywymi podmiotami, u których ma doprowadzić do wzrostu wiary i uzdolnić do dawania świadectwa przeżywanej wiary ${ }^{17}$. Nie jest to posługa wobec słowa Bożego traktowanego uniwersalnie (jak w przypadku teologii i częściowo Urzędu Nauczycielskiego), czyli zmierzająca do jego systematyzacji czy też do jego zrozumienia w kontekście kultury bądź sytuacji Kościoła, abstrahując od jego związku z konkretnymi osobami, które tym słowem żyją. Katecheza ma odniesienie do słowa Bożego w jego przeżywaniu przez konkretnego człowieka. Ma na celu wzrost jego wiary, także jako poznania i wiedzy. Dlatego też wchodzi w proces wychowawczy, kładąc nacisk na rozwój myśli w przylgnięciu do nauczania wiary. W tym sensie jest podobna do teologii, gdyż ma odniesienie do treści wiary jako określonego zbioru prawd podanych do wierzenia. Jednak w odróżnieniu od teologii troszczy się o przylgnięcie do nauczania wiary przez rozum i serce wierzącego, w taki sposób, by wierzący poruszał się w ramach słowa jak w ramach jednorodnego i harmonijnego świata, nie tyle łącząc się z abstrakcyjnym systemem, ile raczej starając się wyrazić go w życiu rozumianym jako odpowiedź. Papież Jan Paweł II tak określa zadanie katechezy: „Katecheza [...] nie ogranicza się oczywiście do zwyczajnego przekazywania wiadomości. Jej

15 Tenże, Verità e interpretazione, Milano 1971, s. 53.

16 Por. Y. Congar, Eglise et papauté, s. 299-315 (rozdział: Bref historique des formes du "magister" et des ses relations avec les docteurs).

17 Por. F. Macharski, Communication de la foi et épreuve de la foi, „La Documentation Catholique" 65 (1983) nr 5 (1847) s. 273-276. 
zadaniem jest «doprowadzenie do pełni i codzienne zasilanie życia chrześcijańskiego wierzących każdego wieku», tak by wierzący został «przeniknięty» misterium Chrystusa i nauczył się w ten sposób coraz bardziej «myśleć jak On, oceniać jak On, postępować zgodnie z Jego przykazaniami i ufać, tak jak On nas do tego wzywa»"18.

W katechezie chodzi więc o to, by doprowadzić do wytworzenia pewnej mentalności, bardziej metody życia niż wyuczenia pewnego zbioru formuł; chodzi o wprowadzenie do określonego stylu życia opartego na wierze. Cel katechezy jest więc eklezjalny, apostolski i misyjny, czyli jest związany ze świadectwem. Dojrzałym w wierze jest ten, kto w pełni przyjmuje w swoim życiu słowo Boże, włącza je do osobistej kultury oraz przekazuje je braciom, aby wspomóc ich w osobowym przyjmowaniu tego słowa i egzystencjalnym przeżywaniu go. Katecheza wymaga więc pewnej systematyczności, ale zasada, według której organizuje ona prawdy wiary, powinna być raczej związana z podmiotem, który przyjmuje prawdy wiary, niż z przedmiotem wiary, nawet jeśli także od katechezy wymaga się dzisiaj dialogu z kulturą i mentalnością współczesną. Pierwszorzędnie jest to zadanie spoczywające na teologii.

Nie interesuje nas w tym miejscu, w jaki sposób można aktualizować ten cel katechezy. To „jak” jest bardzo różnorodne i złożone, zależne od konkretnej epoki i potrzeb pokoleńn ${ }^{19}$; nie jest jednak bezpośrednim zadaniem teologa podejmowanie tego zagadnienia. W tym miejscu należy podkreślić, że katecheza ma troszczyć się o wiedzę, ma myśleć w relacji do wiary, rozumianej także w sposób integralny i uwzględniającej jej specyficzną systematyczność z której narodził się między innymi katechizm jako narzędzie katechezy ${ }^{20}$ - ale zawsze w odniesieniu do konkretnych wierzących, którzy mają otrzymać nauczanie wiary i przylgnąć do niego w sposób najbardziej osobisty. Także język i całość znaków wyrażających

18 Jan Paweł II, Przemówienie przed niedzielna modlitwa „Anioł Pański” (6 grudnia 1992), 2, [w:] Powstanie i znaczenie Katechizmu Kościota Katolickiego, s. 44.

19 Por. G. Dannels, Foi chrétienne et blessures de l'homme contemporaine, „La Documentation Catholique" 65 (1983) nr 5 (1847), s. 267-273.

20 Por. E. Germain, 2000 ans d'éducation de la foi, Paris 1983. 
wiarę powinny odpowiadać konkretnemu przeżyciu i doświadczeniu. Nauczanie pasterzy może zaproponować wspólny język, teologia może zbudować język specjalistyczny i uniwersalny, ale na katechezie spoczywa zadanie wprowadzenia w myślenie i mówienie, które odpowiadają konkretnemu przeżyciu i doświadczeniu wierzących $^{21}$ oraz które prowadzą ich do dojrzałości w wierze ${ }^{22}$.

\section{W KIERUNKU WSPÓŁDZIAŁANIA}

Po określeniu specyficznych ról i zadań spełnianych przez trzy posługi w stosunku do słowa Bożego i do Kościoła, trzeba zapytać o możliwości ich harmonijnego współdziałania. Wyłania się tutaj zagadnienie katolickości słowa Bożego i Kościoła. Chodzi o zastosowanie wielkiej i ważnej zasady, która zobowiązuje do traktowania tajemnicy jako „całości”. W różny sposób mówi się dzisiaj o katolickości. Jest ona synonimem „jedności w różnorodności”, przy czym chodzi o różnorodność uprawnioną, komplementarną, a nie opartą na przeciwieństwach. Mówi się o „różnorodności pojednanej”, by podkreślić pozytywne znaczenie różnorodności. W Kościele role i zadania, nawet jeśli pogłębiają się ich specjalizacje, powinny być widziane jako charyzmaty. Tylko w taki sposób uniknie się tendencji monopolizujących oraz podporządkowujących, pozwalając każdemu wyrazić się w sposób najbardziej odpowiedni i najbardziej owocny ${ }^{23}$.

Wyjście od różnych zadań, proponując, aby każde wyraziło się w sposób najbardziej odpowiedni i specyficzny, nie oznacza, by każdy został zostawiony sobie i by arbitralnie kierował się swoją specjalizacją. Oznaczałoby to anarchię i indywidualizm, egoizm, a nawet idolatrię. Prawdziwym znakiem autentyczności jakiegoś daru jest szacunek dla darów posiadanych przez innych oraz gotowość do

21 Por. J. Ratzinger, Przekazywanie i źródta wiary, s. 85-87.

22 Por. G. Angelini, L'adulto che viene alla fede e la necessità di una chiesa „adulta”, „La Scuola Cattolica” 27 (1999) s. 195-217.

23 Por. Y. Congar, Diversité et communion. Dossier historique et conclusion théologique, Paris 1982, s. 19-68. 
współdziałania z wszystkimi innymi. Oczywiście na pasterzach spoczywa troska o jedność i harmonię między różnymi posługami, ale nie tylko na nich spoczywa trud podjęcia tego zadania. Troska o zharmonizowanie dotyczy każdej posługi i każdej misji. Teologia nie może pracować tak, jakby nie była obowiązana do zwracania uwagi na to, czego uczą pasterze, ani jakby nie miała uwzględniać tego, co robi katecheza.

Zachodzi potrzeba wprowadzenia i utrzymywania procesu stałej i owocnej wymiany między urzędem nauczycielskim, teologią i katechezą, w klimacie wspólnego celu oraz wzajemnego dawania i otrzymywania. Każdy może wzrastać tylko o tyle, o ile przyjmuje to, co osiągnęli inni i o ile przyczynia się do wzrostu innych. Tymczasem zdarza się niekiedy, że teologia dystansuje się od katechezy, jakby bojąc się utraty swojej naukowości, traktując katechezę jako coś, co nie ma znaczenia dla problemu prawdy i weryfikacji wiary, coś, co nie wnosi niczego do refleksji teologicznej. Katecheza ze swej strony niekiedy deprecjonuje tak zwane wywody abstrakcyjne i uogólnienia teologii lub domaga się, by zeszła ona na poziom katechezy w języku i metodzie. Niekiedy zarówno teologia, jak i katecheza dystansują się od Urzędu Nauczycielskiego jako formy nacisku bądź lekceważą jego wskazania jako pozbawione odniesienia do życia.

Wedle kryteriów eklezjologicznych sytuacja różnych zadań i posług domaga się zwrócenia uwagi na możliwości rzeczywistego spotkania omawianych tutaj trzech posług oraz szukania sposobów otwierających na ich współdziałanie. Trzeba więc szukać szerszych i bardziej dostosowanych płaszczyzn dialogu i wzajemnego zrozumienia, aby móc skuteczniej służyć wspólnocie chrześcijańskiej. Trzy posługi powinny szukać wzajemnej wymiany na trzech poziomach:

- na poziomie ewangelicznego oczyszczenia poprzez wzajemne korygowanie się;

- na poziomie wzajemnego wspierania się i wzajemnej promocji;

- na poziomie dążenia do celu, jaki wyznacza ideał ewangeliczny i eklezjalny. 
W pierwszych wiekach chrześcijaństwa pasterz wspólnoty był jedną i jedyną osobą, łącząc w sobie trzy posługi; on był równocześnie przewodnikiem, teologiem i katechetą. Dzisiaj nie jest to już możliwe i nie wróci ten typ jedności. W tej sytuacji staje się konieczne dążenie do szerszego i stałego współdziałania między różnymi posługami eklezjalnymi. Nie może to być tylko założenie realizowane okazjonalnie. Chodzi tutaj o styl życia w Kościele i ze względu na Kościół. Celem nie jest oczywiście dobre funkcjonowanie poszczególnych posług, ale całościowy wzrost wspólnoty chrześcijańskiej w zdolności do wzajemnego słuchania się oraz w gotowości do wzajemnej recepcji, aby wszyscy stawali się coraz bardziej dojrzali w wierze i w świadectwie, opierając się na jedynym i ostatecznym fundamencie słowa Bożego. 


\section{ROZDZIAE XV}

\section{米 \\ Teologia i piękno}

\section{ZMIENNE SZCZĘŚCIE PIĘKNA W TEOLOGII}

Podejmując kwestię związków między teologią i pięknem, należy na początku stwierdzić bardzo podstawowy fakt: piękno pojawia się w teologii od tego momentu, od którego można mówić o teologii. A początek teologii należy ponad wszelką wątpliwość łączyć ze św. Ireneuszem z Lyonu, nazywanym powszechnie „pierwszym teologiem". Podejmując w dziele Adversus haereses wykład i obronę „reguły wiary”, wyszedł poza wprawdzie ważne eklezjalnie, chociaż zawężone ramy kaznodziejskiego komentowania i aktualizowania Biblii. Włączył w logikę swojego dzieła także bogate treści zaczerpnięte z kultury starożytnej, a zwłaszcza z filozofii. Włączenie tego narzędzia umysłowego do refleksji nad wiarą wyznacza w sensie ścisłym początek teologii. Z punktu widzenia samych związków teologii i piękna należy zauważyć, że u Ireneusza pojawiają się elementy "estetyczne", to znaczy uwzględnia on kategorię piękna w swoim mówieniu o Bogu i o postępowaniu człowieka. To samo możemy powiedzieć o całej tradycji patrystycznej, w której wątki estetyczne są bogato reprezentowane. Wprowadzony przez Ireneusza do mówienia o Bogu i o człowieku odkupionym element piękna stopniowo zaczął zdobywać sobie prawo obywatelstwa w teologii ojców, najwyższą formę wyrazu znajdując u tajemniczego Dionizego 
Areopagity. Gdy jednak przyjrzymy się szerzej historii teologii, to raczej z łatwością zauważymy, że mimo niejednokrotnie wspaniałych kart napisanych o pięknie Boga i pięknie wierzącego, aż do XIX wieku nie znajdujemy właściwie żadnego systematycznego rozwinięcia tej kwestii w teologii, jak również organicznego włączenia jej do wielkich systemów teologicznych. Na próżno szukać go na przykład w mających podstawowe znaczenie traktatach De Deo Uno et Trino.

Pierwszym teologiem, który wprawdzie jeszcze w wąskim zakresie, ale już systematycznie włączył kwestię piękna Boga do dogmatyki, był niemiecki teolog Matthias J. Scheeben. Jednak dla dokonania przełomu trzeba było dopiero Hansa Ursa von Balthasara, który najpierw tę kwestię postawił, a potem nadał jej systematyczny kształt w monumentalnym dziele: Herrlichkeit, pojętym jako „estetyka teologiczna". Ujęcie zaproponowane w tym dziele, z powodu swojej przełomowej wymowy i szczytowej formy wyrazu sprawia, że można mówić i rzeczywiście mówi się o „estetyce teologicznej” przed i po Balthasarze ${ }^{1}$.

Zanim przejdziemy do zwrócenia uwagi na propozycję teologiczno-estetyczną Hansa Ursa von Balthasara i jej trwałe znaczenie, zatrzymajmy się nad kwestią piękna, a zwłaszcza nad trudnościami, z jakimi spotykało się ono w minionych epokach w filozofii i teologii. Są one żywe i bardzo widoczne także dzisiaj, gdy chcemy szerzej podążać w teologii „drogą piękna”. Trzeba dobrze zdać sobie z nich sprawę, gdyż chcąc włączyć do teologii kategorię piękna, napotyka się w tym względzie na dwie, dość oczywiste, ciągle te same trudności.

Pierwsza trudność była i pozostaje związana z samą definicją piękna, której poszukiwali filozofowie. Podstawowa i najbardziej

1 Por. M. Hartmann, Ästhetik als ein Grundbegriff fundamentaler Theologie. Eine Untersuchung zu Hans Urs von Balthasar, St. Ottilien 1985; J. Riches, The analogy of beauty. The theology of Hans Urs von Balthasar, Edinburgh 1986; B. McGregor, Th. Norris, The beauty of Christ. An introduction to the theology of Hans Urs von Balthasar, Edinburgh 1994; A. Nichols, The word has been abroad. A guide through Balthasar's Aesthetics, Washington 1998. 
rozpowszechniona filozoficzna definicja piękna stwierdza, iż piękne jest „to, co podoba się oczom” (quod placet visu). Bóg, będąc niewidzialny dla człowieka, wymyka się ludzkim oczom, a więc mówienie o Jego pięknie napotyka na zasadniczą trudność i zdaje się sytuować nie tylko na najwyższym poziomie abstrakcji, ale nawet jawi się jako coś ezoterycznego. Oczywiście piękno, należąc do transcendentaliów tak jak prawda i dobro, wpisuje się w naturę Boga, który reprezentuje je w najwyższym stopniu i w formie uosobionej, ale uchwycenie i opisanie go w Bogu nie jest wcale proste. Tradycyjne definicje filozoficzne nie mogą dostarczyć tutaj łatwych analogii. Owszem, można starać się uchwycić piękno Boga za pośrednictwem dzieła stworzenia czy też analizując przejawy Jego działania $\mathrm{w}$ historii zbawienia, czego teologia nigdy nie zaniedbywała, ale możliwości i faktyczne efekty takiego postępowania teologicznego są dość ograniczone. Mamy w tym przypadku do czynienia z typowym przykładem szukania natury rzeczy wyłącznie za pośrednictwem jej zewnętrznych przejawów, czyli skutków, które powoduje. Wiadomo tymczasem, że postępowanie drogą przechodzącą od skutków do natury rzeczy jest bardzo słabym narzędziem osiągania efektów w interpretowaniu tej natury, którego teologia właściwie stara się unikać, odwołując się do niego tylko w przypadkach ostatecznych. Z łatwością zauważamy, że w takiej interpretacji bardzo łatwo popaść w ezoteryzm, który jest skrajnie niebezpieczny dla prawdziwej religii i teologii. Stąd też daje się zauważyć daleko posunięta wstrzemięźliwość - nawet u mistyków, gdy mówią o swojej relacji z Bogiem - w wykorzystywaniu kategorii estetycznych. Właściwie może nawet zaskakiwać, dlaczego kwestie piękna są w tak małym zakresie obecne w ich doświadczeniach, a w konsekwencji także w ich pismach.

Druga trudność jest związana z samą specyfiką teologii, która rozwija się, począwszy od średniowiecznej scholastyki. Na teologii nowożytnej zaważyły dane przez teologów jednostronne interpretacje propozycji św. Tomasza z Akwinu dotyczącej natury i metody teologii, sformułowanej w słynnej Quaestio prima: De sacra doctrina otwierającej jego Sumę teologii. Ujęcie Akwinaty w swoim pierwotnym wyrazie jest dość zrównoważone. Podkreślił on najpierw, że 
teologia jest wiedzą „argumentatywną”, czyli opiera się na rozumowaniu i dowodzeniu ${ }^{2}$. Jest to podstawowa rzecz dla naukowego i spekulatywnego wymiaru teologii. Idąc jednak dalej, zadaje pytanie, czy teologia dopuszcza również „wykorzystanie metafor" zarzut („videtur quod non”), że metaforami posługuje się poezja, która jest „najniższa” wśród nauk („est infima inter omnes scientias”), a więc nie przystałoby teologii ich wykorzystywanie, gdyż zajmuje wśród nauk miejsce najwyższe („locum supremum”). W odpowiedzi Tomasz stwierdza, że poeci używają metafor, by „przedstawiać” pewne rzeczy („propter repraesentationem”) ${ }^{4}$, co wynika z faktu, że w sposób naturalny ludziom sprawia to przyjemność („repraesentatio enim naturaliter homini delectabilis est") ${ }^{5}$. Wprawdzie teologia nie ma sprawiać wprost przyjemności, ale czyni to ze względu na konieczność i użyteczność dla człowieka („Sed sacra doctrina utitur metaphoris propter necessitatem et utilitatem") ${ }^{6}$. Tomasz więc akceptuje, wprawdzie w sensie pomocniczym i niejako z konieczności, metaforę jako element wykładu teologicznego, gdyż rozum nie jest w stanie wypowiedzieć wszystkiego i nie wszyscy są w stanie swoim rozumem uchwycić argumenty rozumowe. Użycie metafor w teologii ma więc uzasadnienie antropologiczne; dodatkowo za ujęciem Tomaszowym przemawia podstawowa racja biblijna: Bóg w objawieniu posługuje się także metaforami.

Oczywiście Akwinata nie zatrzymuje się w tym miejscu, gdyż wyraźnie stwierdza wyższość rozumienia racjonalnego nad ogólnikowym uchwyceniem i przyjęciem treści za pośrednictwem jakiejś metafory w jej wymiarze przedstawieniowym. W teologii chodzi o to, by racjonalnie wydobyć z metafory jej właściwą treść i uczynić to w sposób jak najbardziej dogłębny i spójny. Odwołując się do logiki objawienia Bożego, Tomasz stwierdza, że nie pozostaje ono

2 Por. Tomasz z Akwinu, Summa theologiae, I q. 1 a. 8: Utrum haec doctrina sit argumentativa.

3 Por. tamże, I q. 1 a. 9: Utrum sacra scriptura debeat uti metaphoris.

4 Tamże, I q. 1 a. 9 ad 1.

5 Tamże.

6 Tamże. 
nigdy na poziomie obrazu, ale podnosi umysły do poznania opartego na rozumowaniu jako najbardziej odpowiedniego dla człowieka, który ze swej natury jest istotą myślącą i inteligentną („Sed elevet eas [mentes] ad cognitionem intelligibilium") ${ }^{7}$. Tomasz przypomina zatem, że w Biblii zachodzi ścisła więź między obrazem (metaforą) i rozumowaniem: to, co przekazują metafory, zawsze znajduje dopełnienie w ściślejszym i bardziej bezpośrednim wyjaśnieniu rozumowym („Unde ea quae in uno loco Scripturae traduntur sub metaphoris, in aliis locis expressius exponuntur") ${ }^{8}$. Refleksja Tomaszowa jest ważna dla naszego zagadnienia, ponieważ piękno sytuuje się pierwszorzędnie na poziomie metafory, to znaczy może pewne rzeczy ukazywać, i w tym sensie ma walor poznawczy, ale w sensie ścisłym nie ma ono charakteru argumentatywnego, a więc stanowi element postępowania teologicznego, sytuując się niejako na pierwszym poziomie teologii, który zajmuje się przedstawianiem pewnych treści. Trzeba oczywiście pamiętać, że ten poziom nie jest wcale drugorzędny, gdyż również na nim pojawiają się bardzo ważne problemy i wyzwania teologiczne, jak na przykład problem se n su'

Ujęcie zaproponowane przez Akwinatę wpisuje się spójnie w logikę objawienia, mogąc przy tym zaskakiwać swoją otwartością na metaforę, a zatem także pośrednio na samo piękno ${ }^{10}$. Warto zauważyć, że rozmaitych metafor do samej Sumy teologii wprowadził on wyjątkowo dużo. Wydaje się więc niesłuszne oskarżanie Akwinaty o przesadny racjonalizm teologiczny.

Późniejsi komentatorzy św. Tomasza nie docenili jednak zrównoważonej wizji, którą zaproponował, a nawet zaczęli się od niej z premedytacją oddalać. Z biegiem czasu zaczęto doceniać tylko wymiar argumentatywny teologii, eliminując możliwe odniesienia do metafory, a więc i do tych wszystkich środków, które angażuje metafora, a więc głównie symbolu i piękna. Zjawisko to wymownie

Tamże, I q. 1 a. 9 ad 2.

Tamże.

Por. H. Küng, Kunst und Sinnfrage, Zürich-Köln 1980.

10 Por. P. S. Zambruno, La bellezza che salva. L'estetica in Tommaso d'Aquino, Napoli 2008. 
ilustruje głośna, a pod wieloma względami przełomowa i prowadzona na wysokim poziomie merytorycznym debata, która rozgrywała się w XVI wieku, a której bohaterami byli teolog z Lowanium Jacques Masson (Latomus) i słynny Erazm z Rotterdamu. Możemy ją poznać w głównych rysach na podstawie dzieła Erazma Apologia contra Latomi Dialogum ${ }^{11}$. Debata dotyczyła pierwszeństwa teologii biblijnej w stosunku do czysto pojęciowej teologii scholastycznej. Erazm, głęboko związany z badaniami biblijnymi, przyznawał pierwszeństwo teologii biblijnej, które to pierwszeństwo Latomus zdecydowanie kontestował. Według niego teologia biblijna ma charakter wyłącznie „cielesny” - jest podporządkowana przepowiadaniu, czyli celom praktycznym, pełniąc funkcję zachęcającą, natomiast systematyczna teologia scholastyczna, rozwijana przez św. Augustyna (który zresztą uprawiał także tę pierwszą) i św. Tomasza z Akwinu, ma charakter "duchowy”, to znaczy jest naukowa i jako taka może służyć wyjaśnieniu prawd wiary, czyli pozwala na sięgnięcie w głąb rzeczy. W teologii duchowej prymat zostaje więc przyznany pojęciu i z tego powodu wchodzi ona w ściślejsze związki z naukami, które również opierają się na pojęciach, takich jak logika, gnozeologia, metafizyka, czyli ogólnie mówiąc, łączy się organicznie z filozofią. W takiej filozoficznie skoncentrowanej teologii zanika niemal zupełnie zapotrzebowanie na metaforę, a zatem i na piękno, które nie są związane z pojęciami. Podobne debaty, mające podobne cele, chociaż na niższym poziomie, toczono w całej Europie w okresie poreformacyjnym. Ich efektem było zdecydowane zwycięstwo teologii o orientacji pojęciowej, która na długo w dominującym stopniu zadomowiła się w Kościele, przy równoczesnym deprecjonowaniu innych typów teologii.

Na uprzywilejowaną w znacznym stopniu pozycję tego typu teologii wywarła wpływ także sytuacja wewnątrzkościelna. W okresie sporów doktrynalnych, które nasiliły się z powodu reformacji, pojawiła się pilna potrzeba teologii opartej na argumentowaniu, aby mogła spełnić funkcję apologetyczną, zdecydowanie uznawaną za

11 Por. G. Chantraine, L'Apologia ad Latomum. Deux conceptions de la teologie, [w:] Scrinium Erasmianum, t. 2, Leiden 1969, s. 51-75. 
naczelną. Taką też teologię szczególnie doceniano i taką promowano, mając na względzie jej większą użyteczność praktyczną w życiu Kościoła.

Do utrwalenia teologii pojęciowej wydatnie przyczynił się niewątpliwie Kant ze swoją krytyką estetyki, sprowadzając ją ostatecznie do intuicji "czegoś niewypowiedzianego” (das Unnennbare), które w celu nabrania adekwatnego znaczenia domaga się jednak zdecydowanego zaangażowania rozumu. Samo piękno jest bezpojęciowe i nie ma bezpośredniego przejścia od piękna do pojęć. Piękno może jedynie wzbudzić upodobanie, ale ma ono charakter wyłącznie subiektywny ${ }^{12}$. Estetyka w takim ujęciu przyczynia się, owszem, do zadawania pytań, ale nie pozwala na nadanie wyrażeniom estetycznym, w tym także pięknu i jego formom wyrazu, znaczenia przedstawieniowego, a więc nie sytuuje jej na tym pierwszym poziomie teologicznym, na którym bezproblemowo sytuował ją Akwinata. Piękno w ten sposób znowu zostało oddalone od teologii.

Mimo pozytywnych przejawów zainteresowania pięknem w teologii XIX wieku, nie nastąpił jakiś znaczący rozwój tej problematyki. Niewątpliwie wpłynął na to destrukcyjny kryzys modernistyczny, który kładąc nacisk na symboliczny wymiar wszelkiej rzeczywistości religijnej, doprowadził do zakwestionowania racjonalności w wierze, a tym samym i w teologii. Jest rzeczą oczywistą, że reakcją na niego było znowu mocne i jednostronne podkreślenie racjonalności w wierze, a więc i filozofii abstrakcyjnej w teologii neoscholastycznej. Jest jasne, że z powodu swojego dogłębnego związku z symbolizmem w tym kontekście także piękno nie mogło liczyć na przychylność ze strony teologii. Wyraźnie widać tę tendencję na przykład w sztuce kościelnej w drugiej połowie XIX i na początku XX wieku. W nurcie tak zwanego akademizmu prawie zrezygnowano z kwestii piękna na rzecz niemal „czystego” z punktu widzenia intelektualnego ilustrowania prawd wiary. Zadowolono się zewnętrznie estetycznym wykonaniem przedstawień artystycznych, które rażą swoją „statycznością”.

12 Por. I. Kant, Krytyka władzy sadzenia, tłum. J. Gałecki, Warszawa 2004, s. 74-76. 
Trzeba było jeszcze trochę poczekać na lepsze czasy, które przyszły dopiero w kontekście II soboru watykańskiego.

\section{PROPOZYCJA „ESTETYKI TEOLOGICZNEJ” HANSA URSA VON BALTHASARA}

Przełomowa rola w uzasadnieniu nie tylko potrzeby wykorzystania, ale wręcz konieczności uwzględnienia piękna w teologii, jak już wyżej zostało wspomniane, przypada szwajcarskiemu teologowi Hansowi Ursowi von Balthasarowi. Dokonał tego już na progu II soboru watykańskiego, gdy w 1961 roku opublikował pierwszy tom wspomnianego arcydzieła teologicznego Herrlichkeit. Ze względu na złożoność tego dzieła i nośność spekulatywną przywołam tylko ogólne zasady, które sam Balthasar streścił w przyczynku o bardzo szerokim oddziaływaniu, zatytułowanym Sztuka chrześcijańska i przepowiadanie, zamieszczonym w monumentalnej, wielotomowej dogmatyce Mysterium salutis ${ }^{13}$.

W pierwszej części swojej refleksji Balthasar przypomina pewne zasady teologiczne, które uzasadniają włączenie piękna - a więc i różnych rodzajów sztuki, które starają się je wyrazić - do teologii i do przepowiadania. Podstawowe założenie mówi, że objawienie zmierza do „ukazania wspaniałości miłości Bożej”"14. Z tego powodu przyjmuje ono „formę” zrozumiałą dla człowieka, aby w ten sposób móc kształtować historycznie wierzącego i Kościół, a eschatologicznie świat. Bóg, mając taki cel, nie zamyka się w pojęciach, ale „przekracza wszelką miarę ludzką i miłość stworzoną oraz potwierdza się w tym jako czysta chwała Boża"15. Bóg jawi się jako absolutna „wspaniałość”, jak można by za Balthasarem bardziej fenomenologicznie oddać biblijne pojęcie „chwały Bożej”. Oczywiście, Serce Boże pierwszorzędnie objawia się za pośrednictwem słowa.

13 Por. H. U. von Balthasar, Christliche Kunst und Verkündigung, [w:] Mysterium salutis. Grundriss heilsgeschichtlicher Dogmatik, hrsg. von J. Feiner, M. Löhrer, t. 1, Einsiedeln-Zürich-Köln 1965, s. 708-725.

14 Tamże, s. 708.

15 Tamże, s. 709. 
Jednak słowo nie jest w stanie wypowiedzieć wspaniałości Boga, choć odgrywa decydującą rolę w prowadzeniu człowieka do rozumienia; niejako sama natura wspaniałości Bożej, a zwłaszcza jej osobowy charakter, domaga się także odniesienia do innych władz poznawczych i duchowych człowieka. Dlatego też Bóg w objawieniu zwraca się do człowieka w sposób globalny, oddziałując na niego w jego całości zmysłowo-duchowej, aby ukazać mu wspaniałość swojej Osoby. Balthasar podsumowuje: „Przez wszystkie formy zmysłowe i duchowe zdolne wyrażać nie tylko ukazuje się «Istota», ale raczej Osoba nieskończenie-rzeczywiście-istniejąca"16.

Bóg właśnie jako Osoba zwraca się do człowieka w pełni swojej wspaniałości, aby człowiek Go poznał i ukochał, angażując w tym celu wszystkie jego władze i zdolności. Balthasar afirmuje więc niejako na pierwotnym poziomie, że Bóg nieustannie staje się poznawalny w swoim ukazywaniu się w historii zbawienia, nawet jeśli jest ono najbardziej ukryte, jak na przykład w ukrzyżowaniu Jezusa. W tym ukazywaniu się przekazuje człowiekowi to, kim jest i jaki jest. Pojawia się tutaj bardzo podstawowe dla teologii Balthasara utożsamienie osoby z misją - działaniem w Bogu. Na tym też gruncie przełamuje on wspomnianą tradycyjną trudność, która niechętnie podchodzi do przechodzenia poznawczego od skutku (działania) do natury rzeczy. W Bogu byt i działanie utożsamiają się ze sobą, a więc w działaniu objawia się sam Bóg - Ten, który jest. Zwraca ponadto uwagę na ważny w tradycyjnej estetyce element definicji piękna, którym jest sprawianie przez nie pewnego „przyciągania” czy też „fascynacji” wzbudzanej w patrzącym nań człowieku. Bóg w swoim działaniu jawi się jako zbawczo-estetyczny, ponieważ ma ono na celu przyciągnięcie człowieka do Boga i rzeczywiście takiego przyciągania dokonuje.

Wspaniały Bóg objawia się w bardzo określonym celu, a mianowicie w celu wprowadzenia nowej formy w chaos grzechu, w „brzydotę" powodowaną przez człowieka. Z powodu grzechu jest „chaosem bezpostaciowym" (abstossende Gestaltlosigkeit) ${ }^{17}$. Ponieważ

\footnotetext{
16 Tamże.

17 Por. tamże.
} 
„formy i siły uporządkowujące, które działają w stworzeniu jako takie, nie wystarczają do osiągnięcia postaci ostatecznej"18, zachodzi konieczność włączenia się Boga w dokonanie tego uporządkowania. Dokonuje go przez Jezusa Chrystusa, który za pośrednictwem wysłużonej i darmowo udzielanej łaski prowadzi człowieka, a przez niego świat, do „uczestniczenia w postaci Bożej”. Dzięki Jezusowi Chrystusowi i Jego łasce człowiek może więc uczestniczyć we wspaniałości Bożej, o ile osobiście „przemienia się w postać Chrystusa” $(\mathrm{Ga} 4,19)$. Jego najbardziej własną i właściwą drogą prowadzącą do tego celu jest nawró cenie, będące „oglądaniem chwały Bożej”. Nawrócenie jest oczywiście ściśle związane z uprzedzającym działaniem łaski i przyjęciem przez człowieka jej przemieniającej mocy. Łaska jawi się jako wspaniałość Boga obecna i ciągle działająca w świecie. Człowiek odkupiony, żyjący przyjętą łaską i nawróceniem, czyli uświęcony, uczestniczy we wspaniałości Bożej, a zatem staje się piękny. Wyjątkowymi i historycznymi świadkami piękna Bożego stają się więc święci, którym Balthasar nadał również dominujące znaczenie w swojej teologii.

Balthasar przyjmuje jako podstawowy i nienaruszalny fakt historiozbawczy i antropologiczny spójne nakładanie się wspaniałości Bożej na wierzącego zmierzającego do świętości, będącej jej odbiciem i potwierdzeniem w świecie. Piękno Boga przez łaskę i wyrastającą z niej świętość znajduje przedłużenie w człowieku i jego dziejach. Promieniujące i przyciągające działanie Boże wzbudza i utrwala swój blask w harmonii duchowej świętych, którzy przyjmują Bożą prawdę i wyrażają ją przez dobre czyny, czyli składają, idąc za Jezusem, „piękne świadectwo”. Piękno w tej wizji stanowi jakby zwieńczenie przyjęcia prawdy objawionej przez Boga i zaangażowanie jej w nawróceniu, z którego rodzi się nowe postępowanie wcielające Bożą dobroć.

Wspaniałość Boga i dzieła odkupieńczego Jezusa Chrystusa obejmuje więc element piękna i domaga się go, by wyrazić pełnię boskiego działania i pełnię jego skutków, których wspólnym mianowni- 
kiem jest chwała (wspaniałość). Człowiek odkupiony jest żywym miejscem manifestowania się tego piękna, otwierając tym samym ważną możliwość jego poznawania w świecie.

Uzasadnienie teologiczne piękna zaproponowane przez von Balthasara spójnie nakłada się na tradycyjną doktrynę filozoficzną dotyczącą transcendentaliów. Piękno, według Tomasza z Akwinu, jest ściśle związane z dobrem jako jego doskonałość (perfectio), która zamieszkuje w bycie, i jego drogocenność. $Z$ drugiej strony łączy się ono także z prawdą, ponieważ jest tym, co oświeca i wzbudza fascynację: od harmonii dostrzeżonej w rzeczach pozwala przechodzić do harmonii między rzeczywistością i poznającym (zmysł lub duch) ${ }^{19}$. Głębia bytu, z której wypływa poprawne uporządkowanie części (ordo, proportio) jako oświecona jasność - blask (claritas), jest tą jednością, która pozwala każdemu bytowi - oprócz jego przynależności do świata - uczestniczyć w szczególności absolutnie Jednego, ukazując mu tym samym iskierkę transcendentnej i fascynującej drogocenności Boga, a tym samym - w Bogu zyskuje absolutną miłość ${ }^{20}$.

Zasady filozoficzne znajdują bezpośrednie przełożenie na język teologiczny. Bóg jeden w swoim bycie jest prawdą i dobrem, które w swoim manifestowaniu się jawią się jako piękno. Bezpośrednim znakiem piękna teologicznego jest spójność i integralność prawdy Bożej oraz przemieniające, podnoszące i pobudzające dobro Boże, które są łaskawie udzielane przez Boga człowiekowi w historii zbawienia. Osobowy charakter bytu, jedności, prawdy i dobra w Bogu osiąga zwieńczenie w Jego wspaniałości, a promieniując na człowieka, wzbudza w nim fascynację, która stanowi decydujący element ludzkiego doświadczenia piękna. Ten sam schemat możemy odnieść do człowieka. Będąc osobą wewnętrznie zunifikowaną, poznając prawdę i wyrażając ją w dobru, budzi fascynację i przyciąganie, czyli potwierdza swoje piękno. Jego pozostałymi elementami są harmonia i integralność, obejmujące zarówno jego wnętrze, jak i przejawianie się zewnętrzne przez ciało i czyny.

19 Tomasz z Akwinu, Summa theologiae, I q. 5 a. 4 ad 1; I-II q. 27 a. 1 ad 3.

20 Por. H. U. von Balthasar, Christliche Kunst und Verkündigung, s. 710-711. 
W ujęciu zaproponowanym przez Balthasara piękno jawi się jako zwieńczenie Tajemnicy Boga - Jego osobowa wspaniałość, obejmując zarówno Jego byt w sobie, jak i Jego manifestowanie się w historii zbawienia. Jego piękno nie jest jednak poznawane za pośrednictwem prostego spojrzenia, jak chce definicja filozoficzna, ale przede wszystkim za pośrednictwem spojrzenia, które można by nazwać globalnym, angażującym jednocześnie wszystkie władze zmysłowo-duchowe człowieka. Dlatego też w kontekście swoich rozważań o pięknie w teologii Balthasar podkreśla, że chodzi mu o opracowanie „estetyki teologicznej”, a nie tylko jakiegoś estetycznego ujęcia tajemnicy Boga w czysto estetycznej teologii. Obejmuje ona wszystkie tradycyjnie należące do definicji piękna elementy, ale nadaje im nową konfigurację. Jej kluczowym elementem zdaje się być dążenie do harmonii bytu, prawdy i dobra, którego celem jest wzbudzenie przyciągania i fascynacji. Odpowiedzią na nią ze strony człowieka jest świętość, która może być widziana jako wyrażenie i urzeczywistnienie piękna Bożego w człowieku.

\section{MOŻLIWE DROGI TEOLOGICZNE}

Estetyka teologiczna Balthasara, chociaż została przez niego samego usytuowana w ścisłym związku z propozycją klasyczną, zwłaszcza w ujęciu zaproponowanym przez Tomasza z Akwinu, w swoim ostatecznym wyrazie zdecydowanie poza nią wykracza. Akwinata widział w metaforze (pięknie) pierwszy poziom teologii, który dokonuje ukazania pewnej treści, ale domaga się przekroczenia i dopełnienia intelektualnego. Balthasar widzi w pięknie zwieńczenie dyskursu teologicznego. Widoczne wyraźnie przesunięcie, a nawet przeciwstawienie akcentów wynika z tego, że Akwinata w pięknie widział głównie proporcję (harmonię), podczas gdy Balthasar widzi w nim przede wszystkim blask i przyciąganie. Być może wpłynęły na to Balthasarowskie fascynacje muzyką, której piękno w decydującym stopniu polega na promieniowaniu i przyciąganiu ${ }^{21}$.

21 Por. C. Dumont, Un genio musicale, [w:] Hans Urs von Balthasar. Figura e opera, a cura di K. Lehmann, W. Kasper, Casale Monferrato 1991, s. 289-304. 
Wydaje się, że obydwa typy estetyki mogą być wykorzystane w teologii, starającej się postępować drogą piękna. Jawi się więc jako uzasadnione wykorzystanie piękna na poziomie pierwotnym teologii. Może to być urzeczywistniane przez włączenie do teologii metafory, a więc konkretnie poezji, literatury, malarstwa, muzyki, architektury itd., czyli wszystkich dziedzin estetycznej twórczości człowieka, które starają się wyrazić jakieś idee i prawdy szeroko rozumianym językiem piękna. Pozostaje jednak przyznać rację św. Tomaszowi, że szeroko rozumiana estetyka spełnia rolę użyteczną i konieczną ze względu na człowieka, ale sama w sobie jest niewystarczająca. Domaga się dopełnienia opartego na zaangażowaniu rozumu, czyli wejścia na drogę pogłębionej argumentacji, a ta pozostaje nierozerwalnie związana ze słowem.

Mimo widocznego przeciwstawienia pokazuje ona w każdym razie, że poważnie uzasadniona jest troska o to, by wszystkie rodzaje sztuk pięknych bezpośrednio i twórczo angażowały się w wyrażenie treści chrześcijańskich za pomocą swojego własnego języka. Sprawa wydaje się raczej oczywista z teoretycznego punktu widzenia, chociaż zasługuje na nowo na praktyczne dowartościowanie i rozwinięcie. Przyczyniłoby się to na pewno do ożywienia wykładu teologicznego. We współczesnym kryzysie kulturowym teologia mogłaby się również przyczynić do dowartościowania twórczości artystycznej, pokazując jej znaczenie jako mow y o Bogu.

Ważność i aktualność propozycji estetyki teologicznej zaproponowanej przez von Balthasara jest dość powszechnie przyjmowana i za taką opcją należy się niewątpliwie opowiedzieć. Piękno jako zwieńczenie Tajemnicy Boga jawi się jako zadanie do pilnego podjęcia, ale mając na względzie jego urzeczywistnienie zachodzi potrzeba sprecyzowania zasad, na których należałoby oprzeć teologię idącą „drogą piękna”. Kwestia nie jest wcale prosta, ponieważ staje przed nami zadanie nowego dowartościowania teologii systematycznej, a więc spekulatywnej i kontemplacyjnej zarazem. Tymczasem taka teologia znajduje się dzisiaj w poważnym kryzysie. Z drugiej strony, co w kontekście wcześniejszej uwagi o charakterze teocentrycznym jawić się może jako pewien paradoks, estetyka teologiczna zawiera wewnętrzne roszczenie przekładania 
jej na kategorie antropologiczne, a więc i egzystencjalne, które pokazywałyby wierzącemu, w jaki sposób może i powinien stawać się odbiciem piękna Bożego. Pojawiają się więc pytania o teologię moralną, teologię duchowości i praktykę duszpasterską, która odpowiadałaby tak pokazywanej i przekazywanej Tajemnicy Boga. Już na początku warto zauważyć, iż pojawia się pilna potrzeba ujmowania tych dziedzin teologii przekraczających schemat oparty na wypracowywaniu tylko jakiegoś „minimum” na rzecz schematu szukającego „maksimum”. Teologia piękna ma wyraźnie charakter maksymalistyczny ${ }^{22}$.

Bezpośrednie pytania mają jeszcze szersze odniesienia. Nie jest wcale rzeczą prostą pokazanie, w jaki sposób, postępując „drogą piękna", ująć poszczególne traktaty i kwestie teologiczne. Sam Balthasar nie zdołał tego pokazać. Owszem, jego chrystologia może być uznana za przykład konkretyzacji „estetyki teologicznej”, ale inne działy teologii nie otrzymały tak samo rozbudowanej konkretyza$\mathrm{cji}^{23}$. Co więcej, po opublikowaniu Herrlichkeit, Balthasar nie kontynuował już estetyki teologicznej, ale przeszedł do Theodramatik, nowej syntezy spod znaku „dramaturgii teologicznej”, która - przynajmniej w pewnej mierze - oddaliła się od propozycji wcześniejszej.

Podsumowując, można sformułować następujące uwagi. Mamy dzisiaj właściwie dwie możliwości wykorzystania kategorii piękna w teologii. Pierwsza, tradycyjna możliwość sytuuje się na pierwszym, przedstawieniowym poziomie teologii. Piękno w różnych formach wyrazu spełnia w niej rolę alternatywnego języka, który ma moc przemawiania do człowieka i zwracania go do Boga, ale sam w sobie pozostaje niewystarczający, domagając się przede wszystkim słowa. Druga możliwość otwiera odnowione i bardzo szerokie horyzonty, ale jesteśmy dopiero na początku jej wprowadzania do teologii i do życia Kościoła. Staje więc przed nami trudne, ale fascynujące zadanie. Jego urzeczywistnianie będzie wymagało

22 Por. J. Navone, Verso una teologia della bellezza, Cinisello Balsamo 1998.

23 Por. G. Marchesi, La cristologia trinitaria di Hans Urs von Balthasar: Gesù Cristo pienezza della rivelazione e della salvezza, Brescia 1997; V. Donnelly, Saving beauty. Form as the key to Balthasar's Christology, Bern 2007. 
jeszcze wiele refleksji i poszukiwań, aby osiągnęło bardziej skonkretyzowaną formę. W każdym razie możliwość postępowania drogą piękna jest już zdecydowanie otwarta, a doświadczenia teologiczne potwierdzają, że warto nią postępować. 


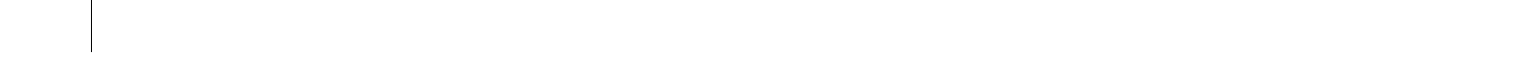




\title{
ROZDZIAŁ XVI
}

\author{
米 \\ Dla Którego miłości. \\ Uroczystość św. Tomasza, \\ nieszpory, 6 marca 2015
}

W modlitwie na zakończenie nieszporów o św. Tomaszu z Akwinu usłyszymy słowa: „Boże, źródło mądrości [...] spraw, abyśmy zrozumieli jego naukę i naśladowali jego czyny". W oryginale łacińskim czytamy: „Deus [...] da nobis, quaesumus; et quae docuit, intellectu conspicere, et quae agit, imitatione complere". Liturgia Kościoła, która w swoich modlitwach i obrzędach jest złotą zasadą kościelnego rozumienia świętych, w swojej wypowiedzi oryginalnej idzie trochę głębiej niż przytoczony tekst polski. Każe nam ona wniknąć głębiej - conspicere - w to, czego Akwinata nauczał, za pośrednictwem naszego intelektu. Intelekt to nie tylko rozum i nie tylko zrozumienie, ale przede wszystkim władza duchowa, dzięki której człowiek, wychodząc od swego wnętrza, zwraca się cały do tego, co się poznaje, aby utożsamić się z poznawanym przedmiotem. Można więc powiedzieć, że liturgia zachęca nas do dogłębnie duchowego utożsamiania się z nauczaniem św. Tomasza.

Ale nie tylko. Idzie jeszcze dalej, bowiem zachęca nas, aby potem to utożsamienie się wewnętrzne $\mathrm{z}$ jego nauczaniem poszło jeszcze dalej, to znaczy: „abyśmy dopełniali naśladowaniem to, co czynił”. Nie tylko naśladowali! Święty Tomasz nie zrobił wszystkiego, co było 
do zrobienia w Kościele i w świecie. Otworzył pewną drogę, którą trzeba iść dalej, dopełniając ją. Nie wystarczy powtórzyć tylko to, co możemy znaleźć w życiu Akwinaty, ale trzeba iść intensywnie dalej. Nauczanie i życie św. Tomasza może i powinno mieć dalszy ciąg w nas. Liturgiczne „et... et” - „i... i” jest bardzo konstruktywne.

Aby jakoś realizować wskazanie, które Kościół kieruje do nas w odniesieniu do życia i dzieła św. Tomasza z Akwinu, spójrzmy syntetycznie na jeden wątek z jego nauczania, związany z jego młodością akademicką. Była to młodość nadzwyczaj żywiołowa, która przeczy dość powszechnemu obrazowi Akwinaty jako jakiegoś nudnego flegmatyka. Żeby się o tym przekonać, wystarczy przeczytać zakończenie dziełka $O$ doskonatości życia duchowego, do którego chcę szerzej w tym miejscu nawiązać ${ }^{1}$.

\section{DOSKONAŁOŚĆ ŻYCIA DUCHOWEGO}

Święty Tomasz zaczął swoją posługę mistrza teologii w Paryżu. Był to okres ożywionego dyskutowania zasadniczych problemów nauki i życia Kościoła. Jednym z żywo dyskutowanych zagadnień była doskonałość życia duchowego, związana przede wszystkim z pojawianiem się nowych form życia w Kościele za sprawą mendykantów (dominikanie i franciszkanie). Wyłoniło się bardzo zasadnicze pytanie, w jaki sposób te nowe formy życia wpisują się w życie Kościoła i czy nie burzą utrwalonych już form życia kościelnego, a zwłaszcza doskonałości stanu biskupiego. Było to w gruncie rzeczy pytanie o wymiar duchowy życia kościelnego w relacji do jego wymiaru instytucjonalnego. Co ma pierwszeństwo w życiu duchowym, do czego jest rzeczą najodpowiedniejszą dążyć w codziennym życiu, jakie praktyki postawić na pierwszym miejscu w życiu chrześcijańskim?

Święty Tomasz z zapałem zaczął swoją misję nauczania, która o tyle natrafiła na sprzyjające okoliczności, że już na początku został poniekąd zmuszony do podjęcia zagadnienia, które łączyło w sobie problematykę najbardziej wówczas eklezjalną z problema-

1 Por. Tomasz z Akwinu, Dzieła wybrane, tłum. J. Salij i in., Kęty 1999, s. 357436. 
tyką najbardziej osobistą. Efektem tej sytuacji i tego wyzwania jest napisane z pasją wspomniane dziełko O doskonałości życia duchowego, w którym nie tylko polemizuje z Gerardem z Abbeville, broniąc autentycznego obrazu Kościoła jako rzeczywistości duchowej, który stawia na doskonałość duchową, ale formułuje także najbardziej osobisty program życia duchowego.

Program doskonałości „ziemskiej” opartej na miłości, wychodząc od trzynastego rozdziału z Pierwszego Listu do Koryntian: „gdybym nie miał miłości, jestem niczym", oraz od Pierwszego Listu św. Jana, w świetle którego miłość jest życiem. Od samego początku Akwinata jawi się jako wielki realista. Widać to choćby w proporcji jego wykładu. Krótko mówi o miłości, którą Bóg kocha samego siebie, stwierdzając, że „żadne stworzenie nie może kochać nieskończenie”, tak jak Bóg. To jest pierwszy stopień miłości, który jest źródłem wszelkiej miłości i jej punktem odniesienia. Drugi stopień miłości - traktowany przez Tomasza nieco szerzej - jest możliwy tylko u zbawionych, a polega on na tym, że „serce rodzi pragnienie, myśl poznanie, dusza - postawę, moc - wykonanie". Błogosławieni w niebie „aktualnie” łączą w harmonijną syntezę wszystkie te doświadczenia duchowe. Trzeba podkreślić to Tomaszowe „aktualnie”, bo habitualnie każdy człowiek - jako pielgrzym na ziemi - ma taką możliwość, ale z racji swojej przygodności naznaczonej grzechem nie jest w stanie tego osiągnąć na ziemi. Miarą ziemskiego życia jest odpowiednie dążenie do tego stanu, dążenie, któremu przysługuje miano „doskonałości”, którą opisuje przykazanie Boże w Księdze Powtórzonego Prawa: „Będziesz miłował Pana Boga swego z całego serca swego i z całej duszy swojej, i z całej mocy swojej" $(6,5)$, a św. Łukasz dodaje: „i ze wszystkiej myśli swojej” (10, 27). Celem tej doskonałości jest osiągnięcie zbawienia.

\section{DOSKONAŁOŚĆ PIELGRZYMÓW}

Jaka doskonałość jest możliwa i konieczna dla pielgrzymów, aby osiągnąc zbawienie? Tomasz odpowiada: „Po pierwsze, człowiek powinien wszystko odnosić do Boga jako do celu". Chodzi o takie pojmowanie życia, by było służbą Bogu. Święty Tomasz jest w tym 
przypadku wierny swojemu podstawowemu założeniu filozoficzno-teologicznemu, według którego w każdym ludzkim działaniu najważniejsza jest przyczyna celowa. Odkrył to już Arystoteles, na którego w tej dziedzinie wielokrotnie powołuje się Akwinata. Przyczyna celowa jest „przyczyna wszystkich przyczyn”. Jest to nie tylko kwestia filozoficzna, ale przede wszystkim teologiczna, ponieważ chce ona powiedzieć, że Bóg jest wszystkim i do Niego wszystko zmierza. Cel zatem powinien stanowić ukierunkowanie ludzkiego działania, czyli powinien kształtować wyrażanie się człowieka jako człowieka. Można powiedzieć, że takie jest życie człowieka, jaki cel obrał sobie w życiu.

Akwinata powołuje się więc na św. Pawła, który w Pierwszym Liście do Koryntian mówi: „Czy jecie czy pijecie, czy cokolwiek innego czynicie, wszystko czyńcie na chwałę Boga" (10, 31). Obranie Boga za cel swego życia w najwyższym stopniu kształtuje ludzki umysł i ludzkie serce, ponieważ poddaje wszystko jednej zasadzie życia i postępowania, która jest zasadą najwyższą. Bóg przyjęty za ostateczny, czyli najbardziej podstawowy cel człowieka dokonuje unifikacji ludzkich czynów, wychodząc od najwyższej zasady, która w języku biblijnym jest po prostu nazywana mądrością. Takie pokierowanie swoim życiem zapewnia to, co mówi II Sobór Watykański na temat duchowości w ogólności, a w szczególności o duchowości kapłańskiej i zakonnej, że jej punktem dojścia jest „jedność życia”. „W ten sposób człowiek kocha Boga z całego serca”.

Tak pojęta pierwsza zasada miłości Boga - zasada ukierunkowująca - ma następnie osiągnąć uszczegółowienie. Pierwszym etapem tego uszczegółowienia jest „poddanie Bogu swojego intelektu i wierzenie w to, co przekazano nam od Boga". Akwinata jest świadomy, że intelekt jest pierwszorzędną władzą duchową człowieka, wpływającą na wszystko, co człowiek pragnie, myśli i dokonuje. Także intelekt jest przeznaczony do tego, by wyrażała się w nim miłość Boga i by tej miłości coraz gorliwiej służyć. Warto to mieć na względzie dzisiaj, a nawet to mocno podkreślić, gdy żyjemy w antyintelektualnych czasach. Trzeba było encykliki Fides et ratio papieża Jana Pawła II, aby przypomnieć naszym czasom, że rozum jest niezastąpiony. Żyjemy w gruncie rzeczy w czasach snu rozumu, 
a dowodzi tego budzenie się demonów. Ta trafna uwaga jest zaczerpnięta z twórczości Francisca Goi, który pojawienie się takiego zjawiska zapowiedział już jakiś czas temu. Bez zaangażowania umysłu odpowiednio do jego właściwości i celowości nie ma autentycznego budzenia się i dojrzewania miłości. Pełnią użycia rozumu jest poddanie go Bogu jako Prawdzie i tym wszystkim prawdom, które On przekazuje człowiekowi. Kochać to nic innego jak postawić na pryncypium prawdy w swoim życiu. „W ten sposób kochamy Boga z całego umysłu".

Drugim etapem uszczegółowienia celu, który człowiek przyjął i realizuje, a więc wędrówki do Boga, jest „kochać wszystko w Bogu i całą swoją postawę we wszystkim odnosić do miłości Boga”. Święty Tomasz na tym etapie, który jest możliwy po spełnieniu poprzedniego, wskazuje na potrzebę widzenia siebie jako zanurzonego w Bogu. Miłość wszystkiego w Bogu zakłada taką wizję rzeczywistości, która jest całkowicie objęta miłością Bożą. Jako taka powinna być ona środowiskiem ludzkiego myślenia i działania, zadając zawsze jako pierwsze pytanie, czy dany czyn respektuje miłość Bożą obecną w świecie. Chodzi o to, by myśleć miłością, a w ten sposób by żadna część rzeczywistości nie była wydzielona z obejmowania jej obecnością miłości Bożej, bo tylko w takim przypadku będzie ona zachowywała realny wpływ na ludzkie działanie. Taka postawa chroni człowieka przed egoistycznym zatrzymywaniem czegoś tylko dla siebie, a więc fundamentalnie chroni człowieka przed grzechem, w którym człowiek stawia siebie ponad Bogiem. Konkretyzacją tego pryncypium jest potem odnoszenie swojej postawy, na którą składają się poszczególne czyny, do miłości Boga, a więc każde ludzkie działanie zakłada podstawowe pytanie o jego relację z miłością Bożą.

Akwinata w swoim wywodzie powołuje się na św. Pawła, który mówi: „Jeśli bowiem odchodzimy od rozumu - to dla Boga; jeśli przytomni jesteśmy - to dla was. Albowiem miłość Chrystusa przynagla nas" (2 Kor 5, 13-14). Miłość, przyjęta za stały punkt odniesienia w działaniu, jest więc światłem, które pokazuje, jaki czyn $\mathrm{w}$ danym momencie jest najbardziej odpowiedni do spełnienia. Oznacza to, że myślenie miłością jest czynnikiem dynamicznym ludzkiego postępowania. W innym miejscu Akwinata powie, że 
kierowanie się miłością jest źródłem spontaniczności, która weryfikuje się w tym, że człowiek nie tylko zawsze wybiera dobro, ale wybiera dobro najbardziej odpowiednie do sytuacji, w której się znajduje i w której postawił go sam Bóg. Można powiedzieć, że etyka większej miłości jest „etyką sytuacyjną” św. Tomasza. Wskazuje ona na to, jak postępować w danej sytuacji, aby była ożywiana coraz większą miłością. „W ten sposób kochamy Boga z całej duszy”.

W końcu św. Tomasz wskazuje jeszcze na trzeci etap ukonkretnienia miłości Boga w życiu chrześcijańskim. Widzi go następująco: „Niech wszystko, co w nas się uzewnętrznia - słowa i czyny wypływa z miłości Bożej". Akwinata zwraca w tym wypadku uwagę na kluczowy element ludzkiego działania, którym jest motywacja. Fenomenologia na początku XX wieku bardzo mocno podkreśliła, że motywacja stanowi kluczowy aspekt czynu ludzkiego (actus humanus), będąc jakby „iskrą” - jak powiedziałby św. Bonawentura wzbudzającą i siłą dopełniającą. Na tym etapie weryfikuje się to, co najgłębsze w ludzkim czynie, nadając właściwą jakość moralną i duchową ludzkiemu postępowaniu. W motywacji wyraża się właściwa siła moralna i duchowa człowieka, która sięga głębi człowieka, w której ociera się on o samego Boga. Jak człowiek motywuje swoje wybory i czyny, tak potem je wykonuje, a w końcu przyjmuje to, czego udało mu się dokonać.

Święty Tomasz na kilka wieków przed fenomenologami - kontemplując przykazanie miłości Boga - odkrył, że motywacja stanowi punkt wyjścia właściwego wyrażenia się człowieka, jego dynamizmu działaniowego i osiągnięcia właściwej dla niego doskonałości, którą weryfikują wybory i rodzące się z nich czyny. Jest oczywiste, że dla Tomasza nie mogło być innej motywacji niż miłość Boża, na którą wskazuje Apostoł Paweł: „Wszystko co wasze, niech się dokonuje w miłości” (1 Kor 16, 14). Akwinata konkluduje: „W ten sposób kochamy Boga z całej mocy".

\section{FINAŁ ŻYCIA AKWINATY}

Dzięki przyjacielowi św. Tomasza, Wilhelmowi z Tocco, znamy ostatnie, dogłębnie szczere słowa, które wypowiedział przed 
śmiercią, przyjmując wiatyk: „Sumo te pretium redemptionis animae meae, sumo te viaticum peregrinationis meae, pro cuius amore studui, vigilavi et laboravi et praedicavi et docui; nihilumquam contra te dixi, sed si quid dixi ignorans, nec sum pertinax in sensu meo; sed si quid male dixi, totum relinquo correctioni Ecclesiae Romanae"2.

„Dla którego miłości studiowałem, czuwałem, i pracowałem, i przepowiadałem, i uczyłem" - wszystko dla miłości Chrystusa: „dla Jego miłości”. Wszystko, co dokonywało się w życiu Akwinaty, było wyznaniem i czynem miłości. W ostatniej chwili życia wyznał pokornie i ze spokojem, że wypełnił to wszystko, co napisał w programie swojego życia na początku swojej działalności - osiągnął doskonałość miłości pielgrzymiej.

Studium, czuwanie-modlitwa, praca, przepowiadanie, nauczanie - to są stałe, powszednie, może nużące elementy naszego życia, które są i mogą stawać się w jeszcze większym stopniu wyznaniem miłości. Także nasze studium, czuwanie, praca, przepowiadanie, nauczanie mogą i powinny coraz dojrzalej stawać się wyznaniem miłości Bożej. Obyśmy mogli mówić, że robimy to wszystko "dla miłości Boga - pro Cuius amore". Obyśmy mogli wyznać na końcu naszego życia, gdy już nie będzie miejsca na udawanie: wszystko było dla miłości Boga: pro Cuius amore.

2 Processus canonizationis Neapoli, [w:] Fontes Vitae S. Thomae Aquinatis notis historicis et criticis illustrati, ed. D. Prümmer e M. H. Laurent, nr 80, s. 379 (proces miał miejsce między 21 lipca a 18 września 1319 roku). 


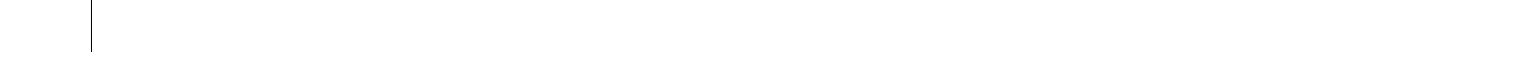




\section{米 \\ Wykaz pierwodruków}

I. Powotanie teologa, [w:] W trosce o petnie wiary. Dokumenty Kongregacji Nauki Wiary 1995-200o, red. J. Królikowski, Z. Zimowski, Tarnów 2002, S. 5-10.

II. Integralność $i$ integracja teologii. Wyzwania stojace przed teologami na poczatku nowego wieku, „Tarnowskie Studia Teologiczne” 23 (2004), s. 251266.

III. Aktualność teologii apofatycznej? - dotychczas niepulikowane.

IV. Teologia droga do madrości. Metoda teologiczna kard. Josepha Ratzingera, „Laetare” (2006) 20-21, s. 156-175.

V. Teologia jako nauka poszukująca sensu, wolności i madrości, „Tarnowskie Studia Teologiczne" 32 (2013) 2, s. 31-42.

VI. Teologia wobec wymogu pastoralności, „Tarnowskie Studia Teologiczne” 33 (2014) 1, s. 109-122.

VII. Nowa ewangelizacja a wspótczesne zawirowania antropologiczne, [w:] Wiara i nowa ewangelizacja, red. K. Lala, Katowice 2013, s. 61-76 (Dni Duchowości, 8).

VIII. Teologia między ortodoksja i ortopraksja, [w:] Tożsamość teologii, red. A. Anderwald, T. Dola, M. Rusecki, Opole 2010, s. 187-201.

IX. Ojcowie Kościoła i teologia, [w:] Fructus Spiritus est Caritas. Księga jubileuszowa ofiarowana Księdzu Profesorowi Franciszkowi Draczkowskiemu z okazji siedemdziesiatej rocznicy urodzin, czterdziestopięciolecia święceń kaptańskich i trzydziestopięciolecia pracy naukowej, red. M. Wysocki, Lublin 2011, s. 217-233. 
X. Teologiczne i duchowe znaczenie historii Kościoła, [w:] Dzieje diecezji tarnowskiej, t. 2: Instytucje $i$ wydarzenia, red. A. Gąsior, J. Królikwoski, Tarnów 2012, s. 49-67.

XI. Studium teologii i apostolat $w$ świetle doświadczenia duchowego $i$ teologii św. Tomasza z Akwinu, „Tarnowskie Studia Teologiczne” 31 (2012), zeszyt okolicznościowy, s. 91-114.

XII. Sensus fidei i sensus fidelium a zadania teologii, [w:] O naturze teologii, red. B. Kochaniewicz, Poznań 2013, s. 57-70 (Studia Theologiae Fundamentalis, 5).

XIII. Teologia - Kościót - polityka, [w:] Lex tua in corde meo. Studia i materialy dedykowane Jego Magnificencji Bp. Tadeuszowi Pieronkowi z okazji 4o-lecia pracy naukowej, red. P. Majer, A. Wójcik, Kraków 2004, s. 91-106.

XIV. Urzad Nauczycielski, teologia i katecheza - „pogtębić istniejace relacje w duchu komunii", [w:] Dzisiejszy katecheta. Stan aktualny $i$ wyzwania, red. J. Stala, Kraków 2002, s. 20-32.

XV. Teologia i piękno, [w:] Cataś piękna jest, Maryjo. Mariologia na drodze piękna. Materiaty z sympozjum mariologicznego i spotkania kustoszy sanktuariów polskich. Skarżysko-Kamienna, 11-12 września 2009 r., red. G. M. Bartosik, J. Karbownik, Częstochowa 2009, s. 25-35.

XVI. Fragment homilii wygłoszonej w uroczystość św. Tomasza, 6 marca 2015 roku, „Vita Academica” (2015) 2, s. 13. 


\section{米 \\ Spis treści}

WPROWAdZENIE $\ldots \ldots \ldots \ldots \ldots \ldots \ldots \ldots \ldots \ldots \ldots \ldots$

Rozdziat I

PowoŁanie teologa $\ldots \ldots \ldots \ldots \ldots \ldots \ldots \ldots \ldots \ldots \ldots$

ROZDZIAE II

INTEGRALNOŚĆ I INTEGRACJA TEOLOGII. WYZWANIA

STOJĄCE PRZED TEOLOGAMI NA POCZĄTKU NOWEGO

WIEKU ............................... 15

1. Sytuacja duchowa dzisiejszej teologii ............. 17

2. Propozycje aktualizujące...................... 26

2.1. Natura i metoda .......................... 26

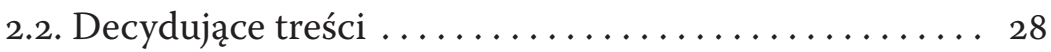

2.3. Kontekst .............................. 32

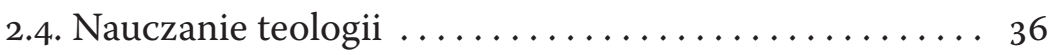

ROZDZIAE III

AktuAlnośĆ TEOLOGil APOFAT YCZnej?............ 39 
1. Źródła teologii apofatycznej .............. 40

2. Podwójne dziedzictwo Dionizego Areopagity . . . . . . . . 43

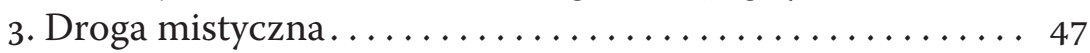

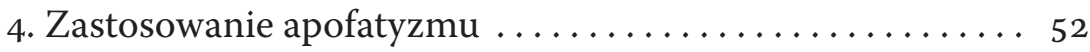

\section{Rozdziat IV}

TeOlogia drogą do MĄdrośCi. Metoda teologiczna KaRdynaŁa Josepha Ratzingera ................ 59

1. W drodze do mądrości ...................... 59

2. Chrystocentryzm ......................... 62

3. Kultura .............................. 64

4. Patrzeć na Chrystusa .......................... 67

5 . Weryfikacja eklezjalna.................... 70

Rozdziat V

TEOLOGIA JAKO NAUKa POSZUKUJĄCA SENSU, WOLNOŚCI I MĄDROŚCI ............................ 77

1. Uzasadnienie teologii w ujęciu św. Tomasza z Akwinu ... 79

2. Otwartość ludzkich poszukiwań na teologię ......... 83

2.1. Poszukiwanie sensu ..................... 84

2.2. Poszukiwanie wolności $\ldots \ldots \ldots \ldots \ldots$........... 86

2.3. Poszukiwanie mądrości ................. 88

3. Dopełnienie metodyczne ludzkich poszukiwań ........ 90

ROZDZIAE VI

TeOlogia WOBEC WyMOgu PASTORALNOŚCI ......... 93

1. Teologia między naukowością i pastoralnością ......... 93

2. Przedmiot teologii ....................... 97

3. Treść wykładu teologicznego .................. 100

4. Jakość duchowa wykładu ..................... 105 
RozDZiat VII

NOWA EWANGELIZACJA A WSPÓŁCZESNE ZAWIROWANIA ANTROPOLOGICZNE $\ldots \ldots \ldots \ldots \ldots \ldots \ldots \ldots \ldots \ldots \ldots . \ldots \ldots$

1. Co to znaczy "nowa” w odniesieniu do ewangelizacji? ... 112

2. Dzisiejszy człowiek ........................ 116

3. Propozycje ......................... 121

RozDZiAe VIII

TEOLOGIA MIĘDZY ORTODOKSJĄ I ORTOPRAKSJĄ......... 127

1. Rozziew między teorią i praktyką ............... 127

2. Z doświadczeń pierwotnego chrześcijaństwa ......... 131

2.1. Idea prawdy .......................... 131

2.2. Praktyka miłości ........................ 134

2.3. Ortodoksja jako postawa ................... 135

2.4. Ortodoksja i wspólnota Kościoła................ 136

3. Propozycje .............................. 138

ROZDZIAE IX

Ojcowie KościoŁa i teologia ................. 141

1. Ojcowie Kościoła w teologii katolickiej ............ 143

2. Ojcowie Kościoła i ekumenizm ................... 149

3. Pojęcie ojców Kościoła i ich autorytet ............ 150

3.1. Ortodoksja ojców Kościoła ................... 152

3.2. Starożytność ojców...................... 154

4. Znaczenie ojców dla teologii katolickiej ........... 157

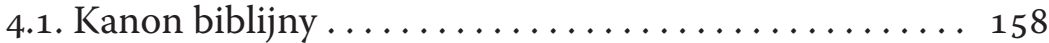

4.2. Regula fidei ............................. 159

4.3. Pierwszeństwo liturgii .................... 160

4.4. Teologia filozoficzna $\ldots \ldots \ldots \ldots \ldots \ldots \ldots \ldots . \ldots \ldots$

4.5. Eklezjalność ojców ....................... 161

5. Zadania na przyszłość $\ldots \ldots \ldots \ldots \ldots \ldots \ldots \ldots \ldots \ldots . \ldots \ldots 2$ 
Rozdzia $X$

TEOLOGICZNE I DUCHOWE ZNACZENIE HISTORII

KościoŁA .............................. 165

1. Historia jako poznanie . . . . . . . . . . . . . . . . . 167

2. Historia Kościoła i jej przedmiot. . . . . . . . . . . . 171

3. Dojrzewanie historiografii kościelnej . . . . . . . . . 176

4. Deontologia historyka ................... 180

5. Nauczanie historii - metoda . . . . . . . . . . . . . 181

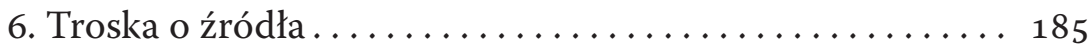

Rozdziat XI

STUdium TeOlogit I APOSTOLAT W ŚWIETLE DOŚWIADCZENIA DUCHOWEgO I TEOLOGII ŚW. TOMASZA

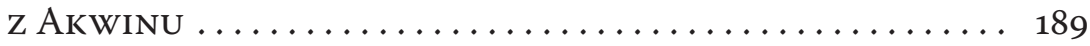

1. Studium i asceza . . . . . . . . . . . . . . . . . . . . . 191

2. Posługa słowa ....................... 212

RozdziAt XII

SENSUS FIDEI I SENSUS FIDELIUM A ZADANIA TEOLOGII . . . 223

1. Kościół jako podmiot wiary . . . . . . . . . . . . 225

2. Eklezjalne doświadczenie wiary . . . . . . . . . 227

3. Sensus fidei . . . . . . . . . . . . . . . . . . . . 230

4. Sensus fidelium ...................... 236

5. Niektóre sugestie . . . . . . . . . . . . . . . . . . . 239

RozdziA XIII

Teologia - Kośció - Polityka. Przemiany

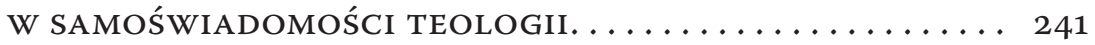

1. Czym jest teologia? . . . . . . . . . . . . . . . 245 
2. Kościół i teologia . . . . . . . . . . . . . . . . . 252

3. Kościół i teologia w działaniu . . . . . . . . . . . . . 255

ROZDZIAE XIV

Urząd NAUCZyCielski, teologia I KateChEZA.

WZAJEMNE RELACJE W DUCHU KOMUNII ........... 261

1. Urząd Nauczycielski Kościoła .................. 263

2. Teologia ................................... 269

3. Katecheza ............................. 272

4. W kierunku współdziałania .................. 274

Rozdziae XV

TEOLOgIA I PIĘKNO ...................... 277

1. Zmienne szczęście piękna $\mathrm{w}$ teologii .............. 277

2. Propozycja „estetyki teologicznej” Hansa Ursa von Balthasara........................... 284

3. Możliwe drogi teologiczne ................. 288

RozDZIAE XVI

Dla KTórego mieości. Uroczystość św. Tomasza, NIESZPORY, 6 MARCA 2015 ...................... 293

1. Doskonałość życia duchowego . . . . . . . . . . . . . . . 294

2. Doskonałość pielgrzymów ..................... 295

3. Finał życia Akwinaty . . . . . . . . . . . . . . . . . . . . . . 299

WYKAZ PIERWODRUKÓW $\ldots \ldots \ldots \ldots \ldots \ldots \ldots \ldots \ldots, 301$ 


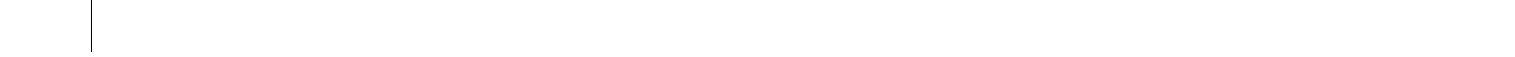

